\title{
NEW FLORA
}

OF NORTH AMERICA

RAFINESQUE 


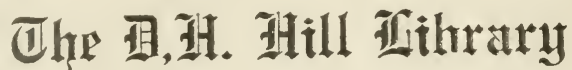

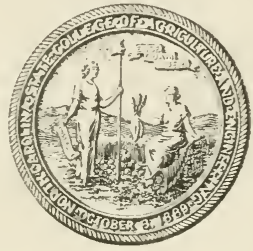

Ninth Caralina State College

$$
\begin{aligned}
& \text { QK110 } \\
& R 34
\end{aligned}
$$

$$
\text { Pax }
$$

\section{4}

This book may be kept out TWO WEEKS

TLY, and is subject to a fine of FIVE

NTS a day thereafter. It is due on the indicated below:

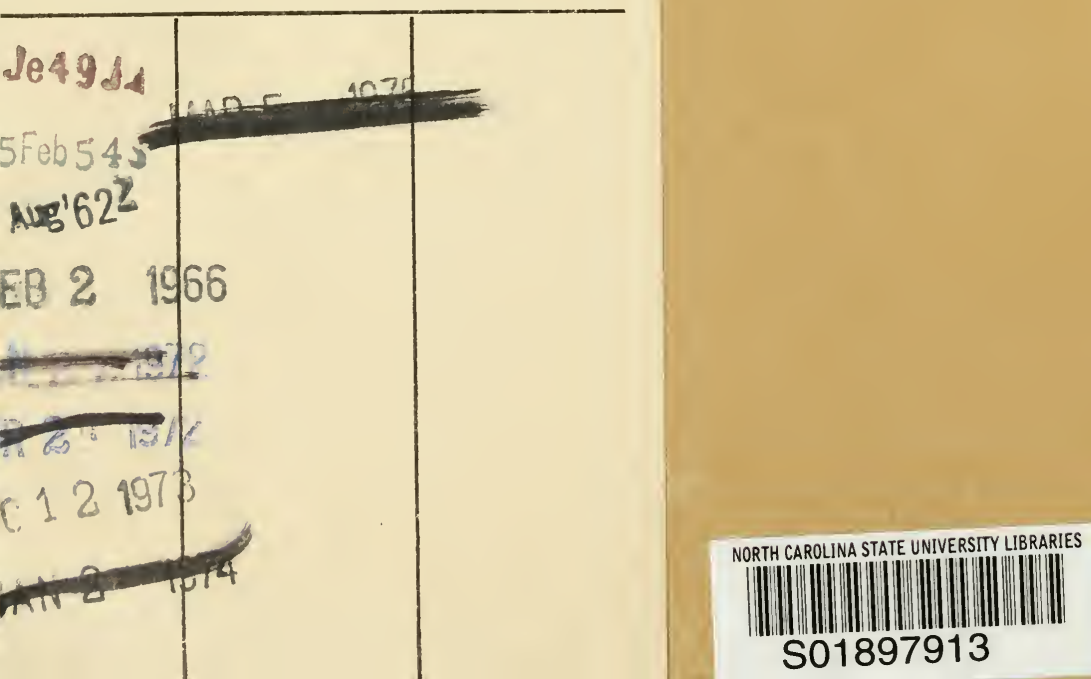




\title{
NEW FLORA
}

\author{
OF
}

NOR'TH AMERICA,

BY

PRUF. RAFINESQZE.

\section{F具马'}

Introduction, Lexicon, Monographs.

PHIL DELPHIA

$\rightarrow$ -

1836. 
Tror iates of issue, see

J.H. Barnhart, Torreya

7: 177-181. 1907.

Pt.I (1836, Decerber)

2 (1837, second half)

3 (1858, first ruarter)

4 (1838, late in year).

PHOTOLITHOGRAPHED BY

THE MURRAY PRINTING COMPANY

CAMBRIDGE, MASSACHUSETTS

FOR THE

ARNOLD ARBORETUM

1946 


\section{9 \\ I N T R O D. L E X I C O N, dec.

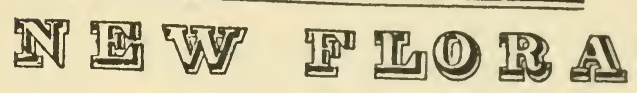 \\ AND BO'TANY}

\section{OF \\ N O R T H A M E R I C A.}

BEING A SUPPLEMENTAL FLORA,

To the various Floras and Botanical Works of Michaux, Muhlenberg, Pursh, Nuttall, Elliot, Torrey, Beck, Eaton, Bigelow, Barton, Robin, Hooker, Riddell, Darling. ton, Schweinitz, Gibbs, \&c.

Besides the general works of Linneus, Wildenow, Vahl, Vitman, Persoon, Lamark, Decandole, Sprengel, Jussieu, Adanson, Necker, Lindley, \&c. Containing nearly 500 additional or revised New Genera, and 1500 additional or corrected New Species, illustrated by figures in Autikon Botanikon.

BY C. S. RAFINESQUE, A. M.-PH. D.

Prof. of Botany, the historical and natural sciencesMember of many learned Societies in Paris, Vienna, Bonn, Bruxelles, Bordeaux, Zurich, Naples, \&c. and in Philadelphia, New York, Cincinnati, Lexington, \&c.

The Floral wealth in this wide land concealed, Will be at last by learned care revealed.

$$
\text { PHILADELPHIA : }
$$

PRINTED FOR THE AUTHOR AND PUBLISHER.

\section{6.}




\section{E D I C A T I O N.}

\section{- 20 om}

To all my fellow Botanists in the United States of North America, and chiefly to those who are endeavoring to complete and illustrate our Botany-I DEDicate these pages, results of 24 years of observations and researches.

But above all, to my friends, colleagues, or contributors now living, and to the memory of the worthy departed, Elliot, Collins, Schweinitz, Pursh, Conrad, Bradbury ... in grateful remembrance of their worth and kind help. . . . . D. D. D.

Philadelphia, September, 1836. THE AUTHOR. 


\section{INTRODUCTION.}

After many years of active researches in the continent of North America, I was meditating to write a new Flora of it; but was long dubious in what form to produce it. To enumerate and describe all the plants of this vast region in a proper form and natural classification, would be a very acceptable labor, but a very arduous task, to which, altho' I felt quite competent, it was not possible to think of, owing to the expense of it, particularly if many figures were given. All our Botanists have shrunk from this undertaking, except Hooker in his Flora of Canada and Boreal America, now publishing by the help of patronage. Zeal alone does not avail in this as in collecting, other pecuniary means are required.

It has been found more practicable and nearly as useful by our Botanists to publish abridged Floras on the Linnean plan, of which Michaux and Pursh gave the example; while Nuttall, Torrey, Eaton, Beck, \&c. have followed nearly the same path. Elliot alone has somewhat enlarged his labor, and produced a most egregious work.

None but such condensed or compiled works on our Botany, have been found acceptable to all and saleable; while the elaborate and learned works, full of discoveries and ample researches, can only be appreciated by a few, and even often excite the envy of the learned rivals. 
Under such predicament, I was compelled to decide upon a middle course; and I therefore undertook this work as a Supplemental Flora of North America, a kind of mantissa and appendix to all my predecessors, avoiding thereby much expense and trouble in accumulating all the scattered materials and fragments already published: altho' I endeavored to collect them whenever I had to frame some peculiar careful monographs of neglected Genera or families. The illustration by figures of my New Genera and New Species will be kept apart in mpt. to be sold apart to any institution or individual that wish to possess them, as well as my botanical specimens, general Herbarium, and original typical sets collected together under the name of my Autikon Botanikon.

I have called this work, a New Flora of North America, and such it is in fact: a real Flora, although not classed by the false sexual system, nor even my own improved natural method, but arranged differently. I do not even know yet exactly how it will be gone through; but I propose to commence by a sample of a Lexicon to be contrasted with the manual Lexicon of Eaton, and go on with monographs of interesting Genera or Families, with a Sycva of my New Trees and Shrubs, a Neogenyton or account of New Genera, and a Neobotanon or compendium of new species. I may, however, deviate from this plan if ncedful or desirable, and I hope to conclude the whole by a general Index, both alphabetical and classified naturally of all the Families and Genera.

While I was preparing this work, I found myself so often perplexed and involved into difficulties, by the actual improper framing of Ge- 
nera, that I was compelled to take up the subject of Generic reform simultaneously with this new flora. This has greatly increased my labors and delayed the publication; but vastly enlarged my field of botanical researches, now based on generic accuracy.

In fact till lately most of the Botanists, both here and elsewhere, were perfectly satisfied with the Linnean Genera, and thought they had done their utmost when they referred the Linnean or new species, quite at random to those Linnean Genera; often avoiding or neglecting to notice their peculiar floral characters, not seldom at variance with the Genera referred to. The labors of Adanson, Jussieu, Necker, Mœnch, Lamark, \&c. upon generic reforms were often overlooked or neglected. At last a better feeling has been prevailing, and the modern improvers Decandole, Agardh, Robert Brown, Lindley, \&c. have rest ored many of the old Genera, or further corrected generic no menclature.

As I rank among these botanical reformers ever since 1808 when I first published new Genera, and 1815 when I published the outlines of my reformed Natural Families, it was just and proper that I should resume these investigations, now that $I$ mean to give the results of a whole life of botanical travels, discoveries and arduous researches. 'This shall then be done in a colateral work published at the same time, but kept apart, which I shall call Flora telluriana or synoptical mantissa of 2000 new families, Genera and species of plants of the whole earth. There most of my generic and other reforms will be elucidated, and I shall merely refer to them in this $\mathbf{N}$. Amer. Flora. 
Here, the new species of this continent shall be chiefly attended to. They are often in as great a disorder as the Genera ; many are occasionally blended into one, or improperly determined and settled. 'To give their synonymy is not always an easy task, nor are the varieties to be overlooked. Many botanists mistake real botanical species for varieties or viceversa. In fact all species might have been varieties once, and many varieties are gradually becoming species by assuming constant and peculiar characters. This is an interesting feature of botanical philosophy, which I shall properly explain and prove hereafter.

This new Flora is very far, therefore, from being a compilation of former labors : it is quite an original work, chiefly based upon my individual researches and discoveries, during 36 years of botanical travels ard exertions, whereof 24 were spent in North America, the main field of my scientific rambles and labors.

It may perhaps be useful to give here an outline of my botanical travels in North America, whereby it will be perceived that I have surveyed and examined more States and regions than any other Botanist perhaps except Nuttall. Thus I was enabled to detect a great number of New Species, and examine many plants alive in full bloom in their native wilds. It would be well if botanical writers would thus detail us their actual excursions and explorations.

Some plants are quite local or have very narrow limits of growth, others are only in bloom for a few hours or days. Many early vernal plants of the Genera Dodecatheon, Clintonia, Vernasolis, Viola, Peltandra, Cypripedium, \&c. can only be seen in narrow localities during 
the month of May. Others of the Genera Gentiana, Kuhnia, Eclipta, Spiranthes, Aster, Solidago, with many radiate Genera, are quite late and autumnal, found chiefly in October: therefore they had escaped the notice of our Botanists, who chiefly botanize or travel in summer.

Other plants are confined to Mountains, or Pinelands, or Western Glades, or deep Swamps, which must be visited by turns, if we wish to collect them. I have sometimes looked in vain for years for some particular plants, at the very places where they are known to grow, because I was not in the due season: this happens to all Botanists, and it is very important for collectors to know the precise epoch of blooming and seeding. What escapes one of them may be met by another a little earlier or later. There are besides years when some plants bloom more abundantly, and others like the Miegia, Enslenia, \&c. only bloom once in many years.

I came to North America in 1802, and travelled chiefly on foot until 1804 , over New Jersey, Pennsylvania, Delaware, Maryland, and Virginia, from the Juniata to the Sea Shore, and from the Alleghany Mountains beyond Easton, to the Potomac beyond Washington and Alexandria. Some of the results of my discoveries in those three ycars of early travels were published in 1808.

In 1805 I left America for Europe, where I remained till 1815. On my return to this continent in that year, I was shipwrecked on the shores of Connecticut, and lost all my former Herbals and collections, buth American and European. 
Therefore being deprived of all my first labors in Botany, Zoology, and Mineralogy in that memorable year 1815, I had to begin again my researches and collections, which I pursued ever since with renewed zeal, always at my own sole expense. I spent 1815 and 1816 in the States of New York, New Jersey; and Pennsylvania chiefly. In 1816 I went to explore as far as Lake Champlain, Vermont, and the Saranac Mountains, near the sources of the Hudson River. In 1817 I went to the Mattawan and Kiskanom, or Catskill Mountains, and explored Long Island, where 1 dwelt awhile.

But my great travels in the West began in 1818, I made a tour of 2000 miles as far as the Wabash River, crossing twice the Alleghany Mountains on foot, and exploring Ohio, Indiana. Illinois, Kentucky, \&c. Some of the results of my former discoveries in that journey were published in 1819 , in the Physical Journal of Paris, in 80 new Gen. of Plants, and 70 New Gen. of Animals.

Having been appointed Professor of Natural Sciences in the University of Lexington, in Kentucky, I went there in 1819 , crossing a third time the Alleghany Mountains, through the Cumberland road of Maryland, still on foot, as I never would cross these beautiful mountains in any other way, in order to botanize all the while, and I was rewarded by many new plants.

I spent seven years in Kentucky in 1826, exploring that State thoroughly, and making excursions to Ohio, \&c., my longest journeys were in 1823, when I went West as far as the Rivers Cumberland and Tennessee near their 
mouths, and next East to the falls of the Cumberland Kiver and the Wasioto or Cumberland mountains.

In 1825 I undertook a long journey through Ohio, and Virginia, crossing the Alleghany mountains of Virginia, and returning by the Alleghanies of Pennsylvania, always on foot. Next year, 1826, I left Kentucky and settled in Philadelphia : but took a very long botanical journey in the way, going through Ohio to Sandusky on Lake Erie; thence to Buffalo, Niagara, Canada, the New York Canal, \&c.

My excursions in 1827, were to the Sea Shores of New Jersey, and thence to Troy, the Taconick mountain, and through Massachusetts to Boston, returning by a different road In 1828, I went to the Alleghany mountains of the North on the Lehigh, the Schooley mountains of New Jersey, and Mattawan mountains of New York. In 1829, I went to the Pine-barrens of New Jersey, and as far as Connecticut. In 1830, I made a second journey to the Kiskanom mountains of New York.

Several botanical excursions and journeys were undertaken in 1831, in Delaware, New Jersey, and the Taconick mountains. While in $1832 \mathrm{I}$ visited Maryland twice, the second tîme $I$ explored the Cotocton mountains of Maryland, and Alleghany mountains as far as Sherman Valley and the Juniata, quite at leisure, residing some times at the top of the mountains.

In the year 1833 I proposed to visit the Apalachian mountains as far as Alabama : but was prevented by an accident and heavy rains: I only went as far as those of Virginia, and again in the Cotocton mountains.-In a second 
journey I undertook to visit the sources of the river Delaware, and Susquehannah, exploring first the Pine barrens and Sea shores of New Jersey, next going from Albany over the Heidelberg mountains to the Lake Utsiantha source of the Delaware at the foot of the Kiskanom mountains, and Lake Otsego source of the Susquehannah.

The year 1834 saw me twice in the Alleghany mountains of the north, once by following the course of the Delaware, the second time westward by the Welsh mountains, Conewago mountains, Albany mountains, Locust mountains to the Pottsville mines and the source of the Schuylkill river, returning by Mauchchunk and Allentown.

My travels of 1835 were in the Central Alleghanies up the River Juniata and Susquehannah, exploring the mountains of Peters, Buffalo, Wiconisco, Mahantango, Tuscarora, Jack, Seven mountains, \&c. with their Valleys. An account of all these travels and excursions is given by me more at length in my Life of travels and researches, published early in 1836. Since then I have chiefly explored South New Jersey and the pine barrens.

Although these journeys were often undertaken with the additional ulterior view to collect Fossils and Animals, my favorite science and pursuit of Botany was always my main object. I always travelled with my botanical collecting book and reams of paper to preserve my plants : and thus I have been enabled to collect in 20 years, since 1816, a most valuable Herbarium, rich in new species, rare plants, and complete Monographs; which have been increased by exchanges and purchases, chiefly of 
Southern plants; not having been able to explore as yet the Southern States, deterred by the bad roads, unhealthy climate, scanty fare, heavy expenses and state of society. A pedestrian Botanist is not always very welcome there.

During so many years of active and arduous explorations, I have met of course all kinds of adventures, fares and treatment. I have been welcomed under the hospitable roof of friends of knowledge or enterprise, else laughed at as a mad Botanist by scornful ignorance. Often deemed a herbalist and wandering doctor by the vulgar, I have allowed or indulged this harmless belief, and thereby elicited from many quarters the local knowledge of medical facts, which I have published in my Medical Flora of the United States.

I have seldom met with liberal enlightened men, who could believe that $I$ was actuated by the pure love of knowledge and science; yet $\mathbf{I}$ have found such worthy men sometimes and their names are gratefully impressed on my memory. Such were J. D. Clifford, Alex. Walsh, Mess. Knevels, Adlum, Dr. Schultz, D. Jackson, H. Clay, Clinton, Meade, Maclane, Wells, Thompson, Aldie, \&c. who without being Bo tanists, or at most mere florists, could apprèciate my pursuits and facilitate my researches. As to Botanists and Zooligists I made it a point to search for them and enjoy their society, mutually imparting our knowledge.

Such a life of travels and exertions has its pleasures and its pains, its sudden delights and deep joys mixt with dangers, trials, difficulties, and troubles. No one could better paint them than myself, who has experienced them all; but 
I must be brief in conveying a slight idea of them.

Let the practical Botanist who wishes like myself to be a pioneer of science, and to increase the knowledge of plants, be fully prepared to meet dangers of all sorts in the wild groves and mountains of America. The mere fatigue of a pedestrian journey is nothing compared to the gloom of solitary forests, when not a human being is met for many miles, and if met he may be mistrusted; when the food and collections must be carried in your pocket or knapsack from day to day; when the fare is not only scanty but sometimes worse; when you must live on corn bread and salt pork, be burnt and steamed by a hot sun at noon, or drenched by rain, even with an umbrella in hand, as I always had.

Musquitoes and flies will often annoy you or suck your blood if you stop or leave a hurried step. Gnats dance betore the eyes and often fall in unless you shut them; insects creep on you and into your ears. Ants crawl on you whenever you rest on the ground, wasps will assail you like furies if you touch their nests. But ticks the worst of all are unavoidable whenever you go among bushes, and stick to you in crowds, filling your skin with pimples and sores. Spiders, gallineps, horse-flies and other obnoxious insects will often beset you, or sorely hurt you. Hateful snakes are met, and if poisonous are very dangerous, some do not warn you off like the Rattle-snakes.

You meet rough or muddy roads to vex you, and blind paths to perplex you, rocks, mountains, and steep ascents. You may often loose your way, and must always have a compass 
with you as I had. You may be lamed in climbing rocks for plants or break your limbs by a fall. You must cross and wade through brooks, creeks, rivers, and swamps. In deep fords or in swift streams you may lose your footing and be drowned. You may be overtaken by a storm, the trees fall around you, the thunder roars and strikes before you. The winds may annoy you, the fire of heaven or of men sets fire to the grass or forest, and you may be surrounded by it, unless you fly for your life.

You may travel over a unhealthy region or in a sickly season, you may fall sick on the road and become helpless, unless you be very careful, abstenious and temperate.

Such are some of the dangers and troubles of a botanical excursion in the mountains and forests of North America. The sedentary botanists or those who travel in carriages or by steamboats, know little of them; those who merely herborize near a city or town, do not appreciate the courage of those who brave such dangers to reap the botanical wealth of the land, nor sufficiently value the collections thus made.

Yet although I have felt all those miseries, I have escaped some to which others are liable. I have never been compelled to sleep at night on the ground, but have always found a shelter. I have never been actually starved, nor assailed by snakes or wild beasts, nor robbed, nor drowned, nor suddenly unwell. Temperance and the disuse of tobacco have partly availed me, and always kept me in health.

In fact 1 never was healthier and happier than when I encountered those dangers, while a 
sedentary life has often made me unhappy or unwell. I like the free range of the woods and glades, I hate the sight of fences like the Indians! The free constant exercise and pleasurable excitement is always conductive to health and pleasure.

The pleasures of a botanical exploration fully compensate for these miseries and dangers, else no one would be a travelling Botanist, nor spend his time and money in vain. Many fairdays and fair-roads are met with, a clear sky or a bracing breeze inspires delight and ease, you breathe the pure air of the country, every rill and brook offers a draught of limpid fluid. What delight to meet with a spring after a thirsty walk, or a bowl of cool milk out of the dairy! What sound sleep at night after a long day's walk, what soothing naps at noon under a shaded tree near a purling brook!

Every step taken into the fields, groves, and hills, appears to afford new enjoyments, Landscapes and Plants jointly meet in your sight. Here is an old acquaintance seen again; thero a novelty, a rare plant, perhaps a new one! greets your view : you hasten to pluck it, examine it, admire, and put it in your book. Then you walk on thinking what it might be, or may be made by you hereafter. You feel an exultation, you are a conqueror, you have made a conquest over Nature, you are going to add a new object, or a page to science. This peaceful conquest has cost no tears, but fills your mind with a proud sensation of not being use. less on earth, of having detected another link of the creative power of GoD.

Such are the delightful feelings of a real botanist, who travels not for lucre nor paltry pay. 
Those who do, often think only of how much the root or the seed or the specimen will fetch at home or in their garden.

When you ramble by turns in the shady groves, grassy glades, rocky hills, or steep mountains, you meet new charms peculiar to each; even the gloomy forest affords a shady walk. Lvery rock, nook, rill . . has peculiar plants inviting your attention. When nothing new nor rare appears, you commune with your mind and your God in lofty thoughts or dreams of happiness. Every pure Botanist is a good man, a happy man, and a religious man! He lives with God in his wide temple not made by hands ....

To these botanical pleasures may be added the anticipation of the future names, places, uses, history, \&c. of the plants you discover. For the winter or season of rest, are reserved the sedentary pleasures of comparing, studying, naming, describing and publishing. A time may come, when if all plants are well known, little will be left to be done, except seeking rare plants or occasional deviations and varieties; but a long while will elapse before this may take place, since so few of our plants are completely known as yet. Then will begin the labors of the draftsman, the collector of rare plants and roots, or the seeking of special and generic deviations.

In this another wide field of researches will be open to the enquiring mind. My thoughts have often been led thereto when noticing singular deviations. I admit like Adanson, Necker and linneus himself that plants do vary gradually and constantly, although often very slowly, both in the specific and generic 
characters. I refor to these authors for exam. ples so often met in gardens ; but $I$ have chiefJy attended to this in the woods and fields where quite spontaneous.

The process is by the seedlings being somewhat different from the parents, and thus evincing a deviation of typical mould, that may be, or may not be, propagated again. If it is, this soon assumes a permanence, becoming a permanent variety if the deviation is slight, such as mere color of flowers, size of stem, leaves, \&c.; but becoming a New Species! if at last several deviations are permanently combined. A tendency to such deviations is sometimes met even in the various annual shoots of the perennial plants, or shrubs and trees, that are not always alike to those of the preceding years.

The specific deviations which I could mention are numberless, this work will be full of them, as all new species are in fact such permanent deviations of growth, unless they are widely different from all former species. The oldest type of the species may probably be found in the most common with most numerous individuals, while those called rare or with few individuals as yet must be the newest in order of time.

Generic deviations are more rarely observed or noticed, because less evident and very slowly produced, or not so easily propagated; but I shall mention here some very striking instances of them; while many more are to be met with in all the Genera, where the characters are polymorphous, expressed by SO ... OR ....SO, 3-5 fidis, 4-5 andris, 3-4 stylis, Capsule with 4 or 5 valves, one or many seeds, \&c.

1. I have seen in a garden a Tulip with 5 
petals only and 5 stamens. That was even a deviation from the family!

2. I have met with a Tecoma bearing a capsule with 3 valves, the generic character is
bivalve.

3. Asters and Solidagos with the ligules mixt with the florets, forming a kind of peloric genus which I have called Mrictanthes.

4. The Aster discoideus of Elliot or my genus Anaciis, has no rays, it must have been a deviated genus like Fclipta from Verbesina. I have met some Asters with the rays so shortened as to be almost invisible.

5. My G. Goroncus has two sorts of flowers and seeds on the same plant, uniting the charracters of Polygomun and Persicaria.

6. My G. Styrandra appears to have" originated once from Convallaria or rather Majanthemum, just like Paris from Trillium.

7. Many monoical and dioical plants return to Polygamy and hermaphroditism. This is the case with some of our Vines, Vitis, Morus, $\boldsymbol{U r}$ tica, Callitriche, \&c.

8. Nothing more common than monstruous deviations by addition or deficiency of parts, which are as many links of generic variations.

Of all the European Floras, that in which generic and specific deviations are most explicitly stated and best detailed, is the Flora Lithuanica of Gilibert, where many similar anomalies may be noticed.

Therefore the result will be that our species and genera are not quite permanent as supposed, but are gradually producing deviations of forms; when these are floral they are of course 
generic, and may after centuries form New Genera.

Hybridity also multiplies species : this process is much more common in plants than animals; but it is often difficult to detect in the wild plants the real parents. Unless they are both found growing near the hybrid, and it has the traces of both forms, we may as safely ascribe it to a natural deviation of frame, called Peloric if floral and generic.

Some Botanists have different ideas of Genera, species, and varieties: their errors and my corrections will be found in the principles of my Flora telluriana. I merely recapitulate here my ideas of them, deduced from $\mathbf{4 0}$ years of botanical observations.

SPECIEs include all the individuals perfectly alike in all their parts-Varieties are slight casual deviations-Proles are permanent varieties, such as are called Breeds among animals.

Genera are the groups of species that have similar floral characters and sometimes a similar habit. Whenever a species has different floral forms it must be a peculiar genus.

Such are the natural distinctions of thase two groups, any others must be unnatural and improper! All species may have been varieties once, except the original types or ancestors of the genus, and all actual varieties may be incipient species.

My views of the natural method will be given in my Frora Telluriana, where I shall correct and improve my former classes, orders and families of 1815 in Analysis of Nature. I have adopted and studied the natural method since 1800 , I have always tried to improve it, 
I have always been opposed to the Linnean system and its blunders; but the natural method has had so long, and has perhaps yet, so many anomalies, that unless they are rectified, the study of affinities will be impeded. Jussieu had a crowd of genera incerta sedis, or annexed to orders without belonging thereto, which were a Dedalus of ambiguity. The modern Decandole, Richard, Lindley, Agardh have partly improved this Labyrintli; but the clue to guide us is now in our hands! Let every genus that does not agree in general frame and characters be removed, and placed elsewhere, as I have done. When this is done and generally adopted we may hope to reach a perfect classification: while that of Lindley for instance, is as yet quite loose and inaccurate, as bad as Adanson or Necker's; since one fourth of his genera do not agree to the common characters ascribed, and some orders have none at all...

This is the ambiguity and absurdity carried from Species and Genera to the National Orders! unless restricted or exploded in all instances, we can have no correct nomenclature nor classification. What absurdity to have an order without definition, like the patched genera Gentiana and Convallaria for instance! a false definition that does not apply to all the Genera or Species, is equal to no definition at all . .

Our North American Botanists were very late in noticing the natural method, and even now hardly admit of it, or else without restriction on its defects. From 1802 to 1804 I was perhaps the only one that followed that new path, Barton, Muhlenberg, and others of that 
period would not even listen to it. Correa alone began to give lectures on it towards 1816, I vainly tried to introduce it in 1817. Pursh, Elliot, Torrey, Nuttall, Eaton, Bigelow, \&c. all wrote their works on the sexual plan. Laton alone added thereto the orders of Jussieu to his manual : yet he was amazed when Torrey published his edition of I indley! Since he and Hooker have begun to open the path in England, Beck and Torrey have begun to follow, while a few others begin to incline towards it: yet Adanson had clisclosed it since 1763, and Robin Flora of Lonisiana used it in 1807.

Its progress will be slow here, because it requires application and study, and my improvements require besides accuracy and perspicuity. It will be easier to follow the blunders of Lindley as formerly those of Linneus without investigation. My own labors on families and genera will perhaps meet the fate of those of Adanson and Necker, and be denied belief or assent for half a century like theirs; but the time will come at last to grant me justice, and admit me among the classical improvers of the science.

Jealousy of my great labors and discoveries may influence sorne; but I hope that real Botanists ought always to be impartial. Torrey is my friend, although we differ in our views of Genera and Species, Nuttall has done so much already and has so much yet to bring forth from Origon, that he need not be jealous of $\mathrm{my}$ labors. Many other Botanists profess to value them. I know of no one that is my avowed foe like Dr. Harlan is for Zoology-I have been liberal and friendly to all, if they do not reci- 
procate, it must be out of bad and improper
feelings.

I have had warm friends and patrons for awhile; but I have been deprived of them all by death already, J. D. Clifiord, Z. Collins, D. Clinton, Dr. Mitchill, (1)r. Jackson, were such. May I meet similar new patrons in my old age !

Although this Flora will exhibit me as a learned Botanist, accurate observer, and zealous discoverer, it does not afford me the means of appearing as a Draftsman, Collector of specimens, Medical Botanist, \&c. for which I must refer to my other works, Medical Botany with 100 figures, my Autikon Botanikon, \&c.

I have written my Botanical Works in 4 lan xुuages, Latin, French, Italian and English! I now write this entirely in English in order to make it available to all our Botanists; but my Flora Telluriana will be partly in. Latin, at least for generic and specific characters.

It is usual for accurate Botanists to state the kind of botanical evidence that they can give, which is usually expressed by vo v. meaning seen alive-v. s. seen dry, \&c. but this may be very delusive since many plants seen alive are only seen in gardens and not in their natural state, or the floral characters have not been examined. Greater accuracy should be required and I state at once that all the plants I describe have been met alive, and collected by me in their native soils, in bloom and seeds unless I otherwise state the facts; whether scen without seeds, or only in gardens.

As to dried or preserved plants, they may also have been with or without seeds; always 
with flowers however and carefully examined generically; although it is not always easy to sce well the minute floral characters of dry specimens. As to the inside of the seeds, their fallacious anatomical structures never perplex me; I leave them to Anatomists with the inside of roots and fibres: microscopical observations are always useless for practical descriptive Botany, as all genera and families have outward evident floral forms peculiar to each.

When plants have not been seen actually alive or dry, I quote as usual the books, authors or figures, that have imparted their knowledge; but few such plants will however be mentioned here, this being rather intended as a collection of my own observations : yet in complete monographs or revised Genera it will be needful to compare all the species and facts. It is to be regretted that our botanists too often neglect the labors of their colleagues, by not comparing all previous or proposed species: whereby they can only give us imperfect monographs.

Severul authors have mistaken foreign plants of distant regions for our own. Many such are found in Thunberg, Gmelin, Loureiro, \&c. that are different species from Japan, Sibiria or Anam. Decandole has recommended to compare again every plant deemed native of several remote regions, and I shall often do it. 


\title{
FLORA OF NORTH AMERICA.
}

\author{
BOTANICAL GEOGRAPHY AND LOCALITIES.
}

Botanical Geography has lately been much attended to since Wildenow, Decandole and Humboldt have written upon it. Dr. Pickering alone has specially written upon that of North America, and although I do not admit of all his conclusions, nor think his map quite correct, yet he has opened the way.

The Earth is divided into botanical regions, where a peculiar growth of trees and plants are found; these regions although sometimes well defined in Islands and Physical regions, must necessarily blend in large continents near their limits.

Wildenow supposed that groups of mountains were the nucleus of these regions, and that the floras expanded around; others think that mountains often divide the botanical as well as physical regions. In North America both seem to be partly the case.

Decandole had only three botanical regions in North America, north of Mexico, the Atlanlic or Apalachian extending to Florida and Missouri, 2d the Origonic or the Origon mountains and plains of the West. 3. the Boreal common to boreal Asia and Europe. Pickering has proved that following the level of the land, the Boreal or Canadian extends South over the Alleghany mountains, while the Mexican region extends North into Texas and Arkansas. 
Eaton has supposed that our Atlantic region was divided in two by the Potomac, the Northern, and the Southern that winds round the mountains to the far West including all the Western States.

These are of course exclusive of the three great regions of the Southern parts, Mexico, Central America and the Antilles.

I have rectified these views since 1832 by increasing our regions to seven; to which $\mathbf{I}$ have given the names of Boreal, Canadian, Alleghanian, Floridian, Louisianian, Texan and Origonian: each of these is perfectly distinct and distinguished both by physical features and peculiar Gencra of plants.

1. Boreal Region, including the Polar region, Groenland, Iceland, Labrador, Hudson Bay and New Sibiria. This wide region, is very similar to the Boreal parts of the Old Continent, Lapland and North Siberia, forming perhaps only one wide circle around the Arctic Pole. It is the poorest of all the American Floras, with very few trees and shrubs, chiefly evergreen, and with the lower classes of plants preponderating, such as Mosses, Lichens, Al gas, \&c. but few Fungi. The floral season is very short, hardly three months from June to August.

2. Canadian Region. This forms a broad belt across the Continent including Nova Scotia, New England, Canada, the countries around the Lakes, and the vast lacustral plains of the West. It has spurs in the northern Alleghanies, the Saranac, Taconick, and Kiskanom mountains. It is distinguished by the prevailing Firs, Willows, and Birches, the Genera Linnea, Diervilla, Parnassia, Rubus, 
Ribes, Coptis, Nemopanthes, Comarum, Caltha, \&c. and an abundance of Mosses, Lichens and Fungi, not however exceeding one half of the whole number The floral season of five months, from May to September.

3. Alleghanian Region. This has for nucleus the Alleghany mountains of Pennsylvania, Maryland, Virginia, Kentucky, \&c. called Apalachian south of Potomac and Wisioto or Cumberland to the West : this region winds all around East and West into the hilly or broken country. It is distinguished by the abundance of trees, oaks, radiate plants, fungi, grasses, leguminose, hypericines, with the prevailing genera Hicoria, Kalmia, Trillium, Azalea, Vitis, Rhododendron, Hydrangea, Heuchera, Lactuca, Solidago, Rosa, \&.c. the Mosses and Lichens are yet abundant,but now form only a small proportion of the whole, while the Fungi are become about one third of the whole. It is remarkable that here the trees and shrubs although yet of the same Genera as in Europe are nearly all unlike in species.Floral season from April to October.

4. Floridian Region. This begins in the North by a narrow belt in the marshy and sandy Islands or Shores, pine woods and swamps of Long Island and New Jersey. widening gradually in the plains of Virginia, Carolina, Georgia, ascending the hills and south Apalachian mountains which run west into Alabama, occupying the whole of Florida, Alabama, \&c. It blends in South Florida with the Antillian flora of Bahama and Cuba, in the mountains with the Alleghanian flora, and west with the Louisianian. It is distinguished by Mag nolias and Pines, Palms and Yricas : the pecu- 
liar Genera Clethra, Fothergila, Passiflora, Chionanthus, Lantana, Marshallia, Xerophylum, Pinkneya, Halesia, Leiophylum, Hudsonia, \&c. with many species of Ilex, Ludwigia, Rhexia, Viburnum, Lobelia, \&c. Here the Mosses, Lichens and Fungi greatly decrease, while the grasses, rushes, ferns, aroides, lilies and akin greatly increase. It is the richest of our Botanical regions in Species, and Vegetation is unceasing, there are flowers in every month, even in January.

5. Louisianian or Missourian Region. The actual state of 1.ouisiana hardly belongs to this; but the ancient Louisiana is the nucleus of it, extending into the plains of 'Tennessee, Kentucky, Illinois, Arkansas, Missouri, and up into the vast plains of the Upper Missouri. The cradle of it appears to be the Ozark mountains. It is distinguished by the Facantree, the Bowtree, the Amorphas, the Planera, Cladrastis, peculiar Pavias and Poplars ; with abundance of Cacti and Ferns; but scanty Mosses, Lichens and Fungi : with the peculiar Genera Miegia, Collinsia, Bellis, Leucospora, \&c. Floral season from March to November.

6. Texian Region. This extends over the wide plains between Louisiana and Mexico, and probably over New Mexico: the nucleus may be the Taos mountains; botanical spurs extend into Arkansas and the Colorado Valley. It is very little known as yet, but the productions are intermediate between Mexican and Louisianian, with abundance of Cactides and Canebrakes. The floral season lasts nearly the whole year as in Florida.

7. Urigon Region. This extends over the Origon mountains and the hilly country west 
of it. We do not know it thoroughly as yet. but what we know of it, is very peculiar. We may hope that Nuttall will describe it botanically. It has perhaps several divisions, the mountains, sea shores, and new Albion or new California to the South. It bears the same botanical relation to Sibiria than the Alleghanies do to Europe. It is distinguished by peculiar trees, Firs, Oaks, Maples, the singular Garrya tree, many species of Ribes, Lupinus, Pentostemon, Cactus, IJimulus, \&c. with peculiar Genera Calochortus, Eutoca, Lasthenia, Collomia, Aegochloa, Lewisia, Clarkia, \&c.-The Labiate, Hypericines, Grasses, Fungi and Mosses appear to be scanty. Liliacea abound, but the Orchides are very few. The floral season extends from March to November in New Albion, but is much shorter in the mountains and to the North.

Besides the above great Regions of this Continent, there are several other Local Regions, more confinerl in limits, but well distinguished by peculiar vegetation or growth of trees. The principal of these are

1. The swampy pine region, where grow the Schubertia and Cupressus thyoides, from New Jersey to Louisiana, with many peculiar water plants. These swamps are unlike marshes by being sandy and having a clear yellow water. In the dry places prevail Pines, Hudsonia, \&c.

2. The Sandy Shore Pegions all along the margin of our Sea from Long Island to Florida; Ilex and Myricas prevail, also shrubs, plants, with palms in the South. The rocky shores of the North are very unlike this.

3. The Alpine Region or Summits of High mountains, where few trees are found, while 
many peculiar plants grow only there. In the Alleghanies they partake of the Canadian flora, and in the White mountains of the Boreal flora.

4. The Prairie Regions of the West, with few trees, but a profusion of fine plants, Dodecatheons, Tradescantias, Helichroas, Gentians, Radiate flowers, \&c., some peculiar shrubs and hardly any Acotyle plant. There the floral season begins in March or sooner as you go South.

5. The Limestone Region of Florida, with a profusion of fine plants, Ludwigias, Rhexias, \&c. and many peculiar shrubs.

6. The Limestone Region of the Ohio, forming a bassin in Ohio, Indiana and Kentucky : it has a very scanty flora, few shrubs in the woods, no Kalmias nor Vacciniums, but among trees many Asiminas and Pavias, with abundance of social grasses or congregated plants.

7. The Apalachian and Wasioto Region, or of the hills and mountains from Kentucky to Georgia: this has a distinct flora from the Alleghanies and Florida shores, many Rhododendrons, Azaleas, Magnolias, and a crowd of fine plants; many yet new in the Unaka or Iron mountains, the northern nucleus of it, as well as in the peninsula of Florida, Alabama, \&c.

Besides these great localities I will add several smaller localities of great botanical interest by the numerous new plants which they have afforded me. Every botanist knows some similar place; but those which I may boast to have discovered or first well explored deserve to be commemorated. They are

1. The neighborhood of Quaker Bridge and Cedar Bridge in the centre of the Pinelands of New Jersey.-2. The neighborhood of Mullica Hill in New Jersey. -3. The sea Islands of New Jersey. - 1. The source of the river 
Delaware in New York at Utsiantha Lake in Oquage mountains.-The Kiskanom or Catakill mountains of New York.-6. The Dismal Swamp of De. laware.-7. Sherman Valley in the Alleghanies.-8. The Cotocton moun. tains of Maryland and Virginia cut through by the Potoriac.-9. Valley of Loyalhannah in west Pennsylvania.-10. Falls of the river Potomac-11. Falls of the river Cumberland in Wasioto, hills of east Kentucky -12. The seryer Wiconisco, Tuscarora and Central mountains of the Alleghanies.-14. The summit of the Allegha. nies in Maryland.-15. The Cacapon mountains of Virginia.-16. The pras. ries of Bigbarren river in Kentucky.-17. The Wasioto IIills and mountains of Kentucky, or Knob Hills, with their knoblicks.-18. The banks of the Wabash, and glades near them.-19. The neck of land between the mouth of Cumberland and Tennessee rivers, with the glades of South Kentucky
and Tennessee.-The shores of Lake Erie near Sandusky.

I hardly need add the far famed fall of Niagara, the head and falls of the Hudson, the Taconick and Mattawan mountains, and in fact every ridge of the Alleghanies. They are all interesting botanical spots to visit; but in order to detect all their plants, you must visit them at least three times, in the Spring, Summer and Fall, or every month from May to October, and even some plants of short floral duration may then escape you. How can we then hope to know all our productions, except gradually and by repeated explorations. I have never been able to meet the Hamiltonia, nor Centunculus, nor Parnassia in full bloom, and many rare plants were only found once by me during 24 years of exploration.

It is 2 mistake to imagine that all our plants are s. ıvan or nemorose, because forests abound in our Continent, The plants growing underneath the shade of trees are not even the major number, and we must look for many in meadows, glades, fields, swamps, sea shores, banks of rivers, brakes, (these are peculiar places in woods or glades where ferns, canes or grasses prevail,) salt licks, rocky hills and cliffs, mountains tops, near springs and brooks.

The distribution of the plants in these localities, and the distribution of peculiar tribes 
over the whole continent, would form an interesting theme, which although partly conjectural and never quite exact, might lead to philosophical reflections and deductions. Some problems remain to be solved on the subject. Why are our North $\Lambda$ merican trees chiefly of European and Siberian Genera, but unsimilar in snecies?

Why are our shrubs still more dissimilar both in genera and species?

Why are our grasses and cyperacea so often similar in species, while the other monocotyle plants are all different?

Why are the minute and simple Acotyle plants, such as Algas, Lichens and Fungi, nearly identic in the two Continents?

Why are Mosses and Hepatica so often similar, while the ferns are less so, and offer many new forms?

Why are many similar forms offered by the tribes of Ranunculacca, Labiate, Juncides, Rosacea, Polygonides, Lysimachides, Veronicides, Borragines, Bicornes, Caryophyles, Amentacea? \&c.

Why are so many dissimilar genera and species found among the Violacea, Irides, Asphodelides, Orchides, Gentianides, Apocynea, Corymbifera, Hypericea, Malvacea, \&c. of both continents?

Why are some families quite lacking in $\mathbf{N}$. America? Such as Rutacea, Guttifera, Protacea, Epacrides, \&c.

Why do the tropical genera so seldom extend into Florida?

Why is the vegetation of Boreal America totally unlike that of Austral America? 
Why have we so few Crucifera, Umbellifera and $N$ arcissides, compared to Europe and Af-
rica?

Why are the two shores of North America, east and west, so unlike to each other in vegetation?

'These queries and other's of a similar nature may exercise the ingenuity of speculative Botanists, or amuse their idle hours; but they are facts and as such deserve our notice.

Another interesting study is that of our naturalized plants. We have so many that they appear to invade the fields and drive out the native plants in some instances; but it is by no means certain but that some deemed naturalized, were not really native. Such at least must have been the case with Verbascum thapsus, Hypericum perforatum, Daucus carota, Anthemis colula, Origanum vulgare, \&c. I gave a long list of the naturalized plants in my dissertation of 1808 , some have since disappeared, while others have appeared instead out of gardens. But few American plants have become spontaneous in Europe, Phytolaca decan$d r a$ and Cenotis canadensis are mentioned as such; but we have received scveral hundreds, besides some few from the Antilles and inland Decandole has properly stated that naturalized plants even when not spontaneous, but extensively cultivated in the open air ought to be added to every general flora, and Eaton has followed that advice with us.

It appears that even previous to the discovery of America by Columbus, our Indian tribes had received or imported from abroad or the South, several trees and plants. I have at least evidently ascertained historically that this was 
the fact with the Maize, Mayzea cerealis (Zea mays of $\mathbf{L}$ ) the Orange tree, the Chicasa plumb Prunus angustifolia, the Catalpa tree, the Peach tree, and the holy plant Nelumbium luteum! besides several kinds of Beans, Tobacco, Potatoes, Squashes, Pumpkins and Melons that were cultivated by our native tribes before Columbus or at least the invasion of Soto between 1540 and 1543, and subsequent French and English colonies.

The number of Genera and Species of each botanical region, and their proportion of Trees, Shrubs, Plants, Herbs, Grasses, Ferns, Mosses, Lichens, Fungi, \&c. is not only variable in each, but difficult to fix, owing to the great number that are common to several blending on the limits. In general the Trees, Shrubs, Ferns and Grasses, increase in number from North to South, while the Acotyle plants diminish; but Fungi are most numerous in the Alleghanian region, by Schweinitz account of them they nearly equal the Phenogamous plants.

However all the calculations heretofore made were erroneous, depending on the peculiar knowledge of the writer and his limited views of Genera. Forster said they were only 1200! in 1771, Eaton in 1833 said exactly 5267! Torrey about 8000 ! I say 15000 and am nearer the truth: at least $\mathbf{1 0 , 0 0 0}$ are Vascular plants in the whole of North America, north of Mexico, with about 5000 cellular plants, whereof nearly 300 are trees or palms. Our largest Flora, the Floridian contains 6000 species at least, while the smallest, the Boreal, has hardly 1000 species, and no more exist in the Limestone region of Kentucky. 'The number of Genera will depend on the reformed view and correction of them. 


\section{MONOGRAPHS,}

\section{WITH NEW GENERA SPECIES AND VARIETIES OF VASCULAR PLAN'S CHIEFLY.}

ABALON Adanson. Veratrun L. Helonias Aiton and all our Botanists. Melanthium Walter, Diclinotrys Raf. meaning two beds racemes.

Dioical. Corolla 6petals linear, Stamens 6 filiform longer, anthers bilobed adnate, Pistillate flowers with 6 rudiments of stamens, pis til 3grooved, 3stigmas sessile reflexed. Capsule ovate 3 grooved 3 celled, cells with many seeds angled acute. Habit, Caulescent, leaves scattered, flowers in long racemes.

Adanson good name meaning not in a ball, was applied to the Helonias of $\mathrm{L}_{\text {. }}$ as this Genus must certainly be divided, this good old name ought to prevail, unless mine of Diclinotrys is prefered. Linneus made many blunders on this plant, uniting to Veratrum and calling it $\boldsymbol{V}$. luteum altho' the flowers are white. We know only one Sp. as yet; but it has many varieties or deviations. The divided stems are found so far apart, that no fecundation can take place. The sterile plants are more common than the others. This pistilate become fertile at a great distance from them.

Abalon (or Diclinotrys) albiflonum Raf. 181\%. Melanthium dioicum Walter, Helonias lutea! Aiton \&c. Hel. dioica. Mx. Pursh, Elliot, Torrey, Beck, Eaton .... :

Very smooth, stem angular, leaves cuneate lanceolate, subacute, enerve: raceme cylindrical, pedicels short, petals linear obtuse. 
Varieties and deviations 1. Pumilum, 6 or 8 inches, leaves narrow, linear above. Mts Alleghany, rare.

2. Sylvaticum, large, bipedal, lower leaves broader and thick, cuneate nearly obtuse: crowded on the stem. In woods.

3. Serpentarium, raceme elongate flexuose like a Snake.

4. Spicatum, flowers nearly sessile forming a long spike, the pistillate flowers remote Kentucky ....

5. Obovatum, radical leaves petiolate obovate nervose, obtuse, stem leaves remote cuneate few obtuse. Alabama and Florida: perhaps a species, fertile flowers very remote.

Flowers white, the pistillate greenish not so crowded-found from Maine to Missouri and Floridas, in meadows, glades and woods. Root tuberose premorse, medical, see my medical flora.

Figures. Autikon Raf. $\mathbf{1}$ to $\mathbf{5}$.

ABAMA of Adanson. His good Genus was wrongly named Tofielda by Hudson; but some American Sp. united to it, being distinct, I called them Conradia or Leptilix in Neog. 1825. Nuttal has named another Genus Conradia in 1834. I therefore restore the $A b a$ ma for our Tofieldas and thus reform the characters.

Arama. Calix small 3dentate. Corolla 6parted obtuse alternate longer. Stamens 6filiform on the corolla and opposite. Pistil one conical 3angular. 3 Styles spreading short, stigmas capitate. One capsule 3celled, 3val. ved, valves bifid above, cells with 2 or more seeds-Habit leaves ensiform, flowers white racemose, peduncles commonly triflore.-Con- 
taining 2 Sub-genera 1. Leptilix Raf. Caulescent, petals broader, capsule 3angular, cells two seeded-2 Triantium Nuttal, Stemless petals narrow, capsule globose, cells with many terete caudate seeds,

Tofielda Subgenus Paltrima Raf. Differs from Abama, by petals equal, stamens longer subulate, dilatated at the base. Styles none or very short, stigmas sessile or nearly so, flat, 3 distincts pistils and capsules, gibbose, opening inside, few seeds angular curved. Stemless flowers almost spiked. This applies to our 2 species : the European are, $\boldsymbol{T}^{\mathrm{T}}$ palustris of borealis. see Tofielda.

Narthecium Smith. No calix, corolla or perigone 6parted spreading persistent. Stam. 6 hirsute, pistil one 3angular, one style stigma 3dentate. Capsul triangular 3celled many seeds caudate. Type $N$. ossifragum and one American Sp.

Therefore the Abama with the capsule of Narthecium has the calix of Tofielda: the Narthecium of Jussieu which is the Toficlda has 6 pistils, stigmas and capsules. Decandole ascribes to Tofielda a capsule with 3 or $\mathbf{6}$ cells ! much confusion arose from the rarity of those plants and incomplete descriptions.

1. Abama (Leptilix) scabra Raf. Toficlda pubens Elliot, Melanthium racemosum Walter. Stem naked above glandular rough, leaves ensiform acute smooth, upper small, peduncles as long as the flowers 2 to 4 fasciculate, capsule 3 gone. In Carolina and Alabama wet pines. Root perennial tuberose.

Stem. 1 or 2 feet, flowers green tipt with purple, estival, petals lanceolale and obovate.

2. Abama (Triantha) pubens Raf. Narthe- 
cium Mx. Anthericum caliculatum Gronovius. Tofielda pubescens Nuttal \&c. Scape pubescent raceme oblong interrupted, capsule globose, leaves ensiform-From Delaware to Carolina, rare; flowers greenish white, petals linear cuneate. Found in Virginia by me. Figure of both Autikon 6 and 7 .-

The other 2 species called Narthecium by Mx. Tofielda by Persoon, and all our botanists, are unknown to me ; but very distinct, and perhaps each the type of another subgenus, since they appear to differ more by the flowers than the leaves.

3. A. pusilla Raf. smooth, leaves very short, scape filiform, flowers few nearly sessile, calix separate from the corolla, capsule globoseLake Mistassin. Subgenus Desurpes Raf.

4. A. GLu'rinosa Raf. Glutinose, stemless, capsule ovoidal double of corolla.-Lake Mistassin. Perhaps a Leptilix.

ABBOT1A Raf. very distinct from Triglochin by 3 Stamens only, more akin to Tristemon or the triandrons Sp of Juncus. See those Genera. Named after Abbot the Botanical and entomological painter:

Calix or perigone simple 3 or 4-leaved, membranous, deciduous. Anthers sessile, commonly 3 seldom 1 or 2 . Pistils 3 or 4 cohering. Stigmas sessile glandular cleft. Capsules 3 or 4 gibbose one seeded, united by spungy membranes like false cells (Elliot)-Stemless, leaves linear, flowers racemose.

1. A. Filiformis Raf. Triglochin triandrum Mx. Elliot and all our Botanists-Leaves filiform, equal to scape, flowers clustered on the spike and on short pedicels, capsules gibbose half connected.-In Carolina and Florida in 
marshes. Scape terete 6 inches, flowers oft with a fourth part.-Figures. Autikon Raf. 8-Ic. N. Sp. 1. Seen dry.

2. A. Palustris Raf. Triglochin palustre L \&c. Leaves linear shorter than scape, raceme slender, flowers remote erect, capsules connected linear equal to pedicels-Found on Lake Erie, pedal, leaves very narrow obtuse, scape terete-Figure Autikon Raf. 9. Seen alive.

3. A. Pumila Raf. Triglochin barrelieri Loesel flora gallica, not in Persoon nor Decandole-Leaves linear thick equal to scape, raceme 4 or 5 flore, capsules connected linear-oblong longer than pedicels-Found on Lake Champlain, annual, 2 or 3 inches high, leaves nearly convex beneath, obtuse.-Fig. Autikon Raf. 10. Ic. N. Sp. 2. seen alive.

ABIES. This good Genus of fine trees distinguished by Tournefort, Adanson, Jussieu and all the correct botanists, was wrongly united to Pinus by Linneus. The Firs are not Pines! the habit is very different, and Jussieu has given a long description of the peculiar fructification. The region of Oregon has afforded many new Firs, well described by Lewis in 1812 and in Atlantic Journal.

1. A. Trigona Raf. 1832. Bark and branches scaly, leaves densely scattered, petiolate trigone acuminate and stiff.-In Oregon, gigantic, 200 to 300 feet high, trunk 40 feet around, leaves 3-fourths of an inch long, one tenth wide. Gigantic Fir.

2. A. heterophyla Raf. 1832. Bark rimose, leaves distichal petiolate, very unequal, sulcate above, glaucous beneath; cones terminal ovate fexible.-In Oregon, reaching 180 
feet, leaves one fourth to one inch long, but all one twentieth wide.-Oddleaf Fir.

3. A. Aromatica Raf. 1832. Branches bullate balsamiferous, leaves densely scattered forming 3 rows, sessile lanceolate obtuse, flexible sulcate and shining above. gibbose beneath. -In Oregon, reaching 100 feet, blisters on the branches filled with a fine aromatic balsam, leaves very small one eighth of an inch long, one sixteenth wide. Aromatic Fir,

4. A. microphyla Raf. 1832. Bark rimose, branches not bullate, leaves densely scattered forming 3 rows, sessile acute sublanceolate.In Oregon, reaching 150 feet high, like the last, but yielding no balsam, leaves still more minute. only one-twelfth of an inch long, one 24th wide, wood white and tough. Scaly Fir.

5. A. mucronata Raf. 1832. Bark scaly, branches virgate, leaves scattered very narrow, rigid and oblique, sulcate above, pale beneath: cones ovate acute, scales rounded nervose mucronate.-In Oregon, reaching 150 feet, leaves subbalsamic, one inch long, one 20th wide, cones very large two 1-2 inches long. Large cone Fir.

Var. palustris. Only 30 feet high, branches spreading. In swamps.

6. A. Falcata Raf. 1832. Bark scaly, leaves in 3 rows, 2 rows upright, one row declinate falcate, all linear lanceolate with trigone petiols: cones fusiform obtuse at both ends. - On the sea shore of Oregon, rising only 35 feet, leaves three 4ths of an inch long, one 5th wide. Sickle Fir.

Of the Atlantic Firs we have 7 or 8 species, all called Pinus!

7. A. Taxifolia Raf. Pinus, Lambert and Eaton. Yew leaf Fir. 
Var patula Raf. Autikon 11. Branches spreading, leaves obtuse, entire hardly glauceous. - Cum berland mts. Spreading Fir.

8. A. Balsamifera Michaux. Balsam Fir.

9. A. Fraseri Raf. Pinus Pursh. Double Spruce Fir.

10. A. Canadensis Mx. Common Spruce Fir.

11. A. Nigra Raf. A. denticulata Mx. Pinus nigra. Aiton. Black SpruceFir.

12. A. Rubra Raf. Pinus Lambert. Red Spruee Fir.

13. A. Alba Mx. Pinus Lambert. White Spruce Fir. All these dwindle to dwarf varieties on the White mts. and in North Canada.

ABRUS. This tropical Genus extends to Florida; but our Sp. has not been described: the $\boldsymbol{A}$. precatorius is said to have 3 varieties with red, white and yellow seeds. They must be again compared, also, the Asiatic, Antillian and Floridan plants. Iinneus once mixt those plants with the Glycine.

ABUTILON. Tournefort, Malvinda Dillen, Sida Linneus \&c. This good old Genus hardly preserved except by Adanson, is perfectly distinct from Sida by the many truncate and 3 seeded capsules around a hollow in a stellate and campanulate form, 10 to 20 with as many styles, the Sida having only 5. There are many species of it; not yet well distinguished, perhaps all the multicapular Sidas of Linneus belong to it, or to the Genus Diadesma.

1. A. mollissimum Raf. $A$ cordatum Med. flora. Autikon. 12. Soft like velvet, leaves orbicular cordate acuminate, erose crenulate, no long petiols; peduncles axillary pauciflore 
short, capsules 12-15 hairy bicorne 3 seeded. - Sida abutilon L. and all the Botanists, but with many varieties, perhaps species? all annual with small yellow flowers.

Var palustris. Stem 2 to 6 feet, leaves crenulate, peduncles triflore, 2 sterile. Swamps of Carolina. Vernal. Elliot.

Var. ruderale. Stem 2 to 6 feet, leaves nearly entire, peduncles 3-5flore. Common among rubbish, in woods and old dry fields from New England to Kentucky. Estival.

Var. uniflorum Raf. Stem pedal or less, simple, few leaves, nearly entire, peduncles uniflore, or only one flower. In waste grounds, rare.

Whether our American varieties are identic with those of Europe, Sibiria, India \&c. is doubtful: the European has stem $\mathbf{5}$ feet high, large entire leaves, peduncles uniflore, calix canaliculate \&c.

2. A. Decarpum Raf. Sida abutiloides Jaquin. Lavatera! Americana L-Tomentose, leaves cordate acuminate, crenate, peduncles uniflore as long as petiols, 10 capsules 3 seeded. -In South Florida, Stem 3-4 pedal. Hardly different from some of the varieties above, but capsules less on longer peduncle. Mistaken for a Lavatera and deemed fruticose by Linneus, a double blunder.

3. A. CRISPum Raf. Sida crispa L. \&c, appears to differ fiom the others by white flowers. a multilocular inflate cristate fruit: certainly no Sida: Michaux and Elliot did not see it, must be examined again. It probably belongs to Cristaria. Leaves oblong cordate, acuminate and crenate. In Florida and Bahama. 
The Sida rhombifolia, S. stellata, S. virgata, S. cardanisea, must belong to Diadesma, which see. The authors enumerate 120 species of this Genus, improperly blended. Anoda and Cristaria of Cavanilles have been properly separated; while Napea of Linneus has been very improperly united to it. Other Genera are hidden in the jumbled Sidns. The true Abutilon has calix not 5angular, nor petals obliquate as in Diadesma and Sida.

ACAKIA Adanson who spelt Akakia, but mispelt Acacia by Wildenow, which being pronounced Acasia becomes blended with Cassia! One of the many genera blended with Mimosa by Lin: We know already $14 \mathrm{Sp}$. of Mimosas in N. America, which may as well be enumerated here at once. They are rare plants in herbals, because difficult to dry, the leaves falling in the process. Eaton has only 7 species.

1. Acakia farnesiana Wildenow \&c. In Louisiana, native.

2. A. Julibrisin. W. native of Asia, but naturalized in Carolina, Virginia and as far north as Philadelphia in gardens. Beautiful tree 20 to 25 feet high, splendid when in bloom. Pods flat as in Darlingtonia, probably a particular genus. Julibrisin arborea $\mathbf{R}$.

3. A. Lutea Leavenworth, (Eaton.) In Alabama, pods ovate, differ from farnesiana by unarmed, folioles numerous and pod ovate.

4. A. Cooleyi Eaton. A. anomyma! Torey W. pl. 106. Leaves bipinnate, very irritable, flowers capitate white, legumes long linear smooth. In Arkansas.

Acakia has the pods unilocular and bivalve, trait. Amosa of Necker. 
Mrmosa has pods multilocular by transverse partitions. 2. Sp.

Darlingronia Dec. pods unilocular bivalve, flat often falcate. $5 \mathrm{Sp}$.

Schrankia. Wild. pods unilocular qualrivalve. $2 \mathrm{Sp}$.

5. Mimosa pudica L. which is said by Bartram to grow spontaneous in Louisiana, deemed a weed; but perhaps it is another Sp. see $\mathrm{fl}$ Lud 445.

6. Mimosa chionacantha Raf. fl. lud. 331. M. eburnea Robin. Perhaps not even a Mimosa, altho' the fruit is similar; but the flowers are different.

M. pudica typical Sp, has cal. trifid, no corolla, 3 or 4 stamens; but this Sp. cal. and corolla irregular, many stamens: therefore type of another Genus Eburnax, Raf. fruticose cespitose aculeate, spines gemimate divergent strait snowy lucid, heads of flowers globose, pods strait terete glutinose.-Sandy fields of Florida and Louisiana.

7. Darlingtonia glandulosa Dec. Mimosa Mx. Acacia W \&c. Pods strait.

8. D. Illinoensis Dec. Mimosa Mx. Acacia brachyloba W. Mg. \&c. The Acacia miamensis of Don \& Mg. Cat, is perhaps this Sp. also, and their A, divaricata of Carolina the glandulosa; both undescribed, but made out distinctly by Mg. I found at the falls of the Cumberland $\mathbf{R}$. in Kentucky, one of these, but without flower nor seed in September.

9. D. Intermedia Torrey W. pl. 107, good description, copied by Eaton, on Arkansas R.

10, D. brevifolia Raf. Herbaceous, inerme, stem 4angular striated, leaves very short bipinnate by 3 pairs of 10 to 12 folioles oblong 
acute pubescent; pods unequal linear contorted, end hooked.--In West Louisiana and Texas, small plant, minute leaves and flowers in peduncled head. Figure in Autikon rare. 14.

11. D. Virgata Raf. fl. lud. 444. Acacia. Mimosa Virgata Bartram. Stem erect, branches virgate, leaves bipinnate; pods oblong on long peduncles, and lunate broad flat contorted.-On the shores of Florida, Herbaceous perennial, flower of a pale greenish yellow. Omitted by all our botanists.

12. Schrankia Wild. Nuttal wrongly says only one species known! Eaton joins to it the $M$. sensitiva of the hot houses! the type is the M. quadrivalvis of Linneus, which includes several Sp. of which I give two.-

13. S. uncinata W. $M$. intsia Walter, $\boldsymbol{M}$ horridula Mx. Prickles hooked, branches angular, leaves bipinnate, peduncles geminate, pods oblong (Elliot) linear terete (Mx.) prickly-Virginia to Florida. Well described by Elliot, flowers purple, vernal.

I4. S. mexicana Raf. M. 4-valvis L. Houston fig. Prickles hooked, branches quadrangular, leaves bipinnate, partial ternate, peduncles axillary, pods linear subulate 4 angular prickly.-In Mexico sea shores, and próüubly in Texas.

ACALYPHA of Linneus, Cupameni of Adanson. Genus well known and natural, well described by the authors, who have adopted the good linnean name, rather than the malabaric name of Adanson. It is a tropical and Asiatic Genus extending to North America. Persoon has $38 \mathrm{Sp}$. (Linneus had only 5) and there are more, since only two are admitted of N. A. nut of the whole. I have ascertained 9 at 
least. Being an unsightly Genus, it is neglected by the Botanists; but many other Sp. exist perhaps in Florida and the South: few of them know well their 2 species, and blend them continually in herbals, having united 3 species in A. Virginica. All have alternate leaves.

1. A. virginica L. or a. crenulata Raf. Stem erect, nearly simple, pilose; leaves longer than petiols, oblong-lanceolate, crenate obtuse pubescent punctate: flowers axillary few monoical, shorter than petiols, involucre crenate.From New England to Carolina. Pedal and annual, leaves small uncial. Seen alive. Estival. Capsule hispid.

Figures. Autikon. Raf. 21.

2. A. Brevipes Raf. Hardly pubescent, stem erect angular simple; leaves on very short petiols, narrow lanceolate, acute, nearly entire: flowers axillary, few monoical, involucre laciniate.-N. Jersey to Alabama and Kentucky. Annual 3 to 6 inches high. The $\boldsymbol{A}$. virginica of many Botanists. Seen alive since 1804. Estival, capsule hispid.

Figures. Autikon. Raf 22.

Var. Linearis. Leaves nearly linear and entire.

Y..r: pubescens, stem and petiols hairy, leaves lanceolate, A. Virginica Michaux.

3. D. divaricata Raf. Pubescent, branches opposite divaricate; leaves on short petiols, ovate obtuse crenate; flowers axillary few monoical equal to petiols, involucres sessile, laciniate. Virginia, Kentucky \&c. annual spreading 1 or 2 feet, Estival, seen alive.

A. Virginica of some Botanists. Capsule hispid.

Figures. Autikon Raf. 23 
4. A. Rhonboidea Raf. nearly smooth, stem virgate nearly simple; leaves on long petiols ovate rhomboidal, acute, serrate; Involucre pedicellate, laciniate, shorter than petioles, flowers monoical caps. hispid.-Pennsylvania to Ohio, Alleghanies \&c. annual, estival, pedal.

A. caroliniana of Michaux and all our Botanists except Walter and Elliot. Eaton says Darlington was the first to find it North; but Muhlenberg and I found it in 1802, deemed then the same as the next.

Figures. Autikon Raf. 24. Lamark tab 780.

5. A. caroliniana Walter, Elliot. Stem strait hairy, leaves on long petiols, oval lanceolate 3 or 5 nerved, pilose, acuminate, serrate, base subcordate, spikes axillary and extra, monoical, involucres sessile laciniate, capsules echinate.-Carolina and Florida. Annual, Estival. Leaves large 2 or 3 inches, involucre small, spikes elongate $\mathbf{2 - 4}$ inches: totally different from last, this might be called $A$. echinata. Elliot was doubtful of the Genus.

6. A. uRticifolia Raf. Stem erect angular grooved smooth; leaves ample ovate acute on long pubescent petiols, base acute, serrate, trinerve with a few hairs : flowers axillary monoical, 2-3 involucres laciniate or palmate, ciliolate, capsules scrobiculate or dotted, smooth. In West Kentucky and Tennessee, discovered in 1818. Sesquipedal, estival, annual. Near the last, but smooth, leaves with only a few adpressed hairs above, flowers not in spikes, few, and capsules with sunken dots. Seen alive.

Figure Autkon Raf. 25.

7. A. digynera Raf. fl. Louis. 369. Stem herbaceous ramose tomentose, leaves petiolate, oblong lanceolate, dentate, villose: involucres 
flat ciliate, 2 pistillate flowers on the peduncle of the staminate flower.-In Louisiana, stem 2 feet, flowers axillary only 3, authers almost in a spike. No figure.

8. A. Fruticulosa Raf. fl. Louis. 368. Shrubby, branches divaricate, rufous tomentose, leaves petiolate ovate dentate : involucres involute unequally dentate, a single pistilate and staminate flowers.-In Louisiana, stem 2 feet, with many slender branches, flowers axillary geminate. No figure.

These two last species neglected by our Botanists, are very distinct and approximate to the tropical species. Linneus states his $\boldsymbol{A}$, virginica to grow in Jamaica and Ceylon, quoting the figures of Brown and Plukenet; they must apply to other kinds, which may be called

9. A. Jamaicensis Raf. Fruticose, leaves ovate-lanceolate longer than petiols, serrate, scabrous: Spikes axillary, involucre multifid (Lin.) but cordate crenate (Brown)-In Jamaica and perhaps in Florida, shrub 4 to 5 feet high. See Brown, Lunan and Jamaica authors. Very different from all ours, perhaps 2 Sp.there.

10. A. zevlanica Raf. In Ceylon, certainly more distinct yet, but $I$ have no materials at hand on it.

ACANTHUS of Lin. Genus foreign to $\mathbf{N}$. America, the following doubtful species may be a Pedicularis.

A. rubens, Raf. fl. Louis. 104. Leaves inerme soft, clasping, broadly sinuate.-In Louisiana near New Orleans! A. mollis Robin. Stem 3 to 4 feet, flowers pale red.

Var Minor smaller, leaves deeper sinuate, flowers remote 
ACER; pronounce Aker not Aser. Of the useful maples, I hardly need give a Monograph, as they are so well known, and the Gr. Negundium is now separated, except by Eaton and such incorrect botanists. Yet some Sp. are not yet well settled, Nuttal unites the A. glabrum with $\boldsymbol{A}$. circinatum Pursh: the $\boldsymbol{A}$. coccineum Mg. is only a variety of A. rubrum; many Sp. are blended as $\boldsymbol{A}$. sacharinum because they produce sugar.

A singular blunder has prevalled for this Genus. All trees are feminine in Latin, whatever be the gender of the generic name: thus we say Quercus alba, Salix nigra, Liriodendron tulipifera \&c. but in some neutral names like this we make the species neutral also! I never could find a botanist or latin scholar to explain the cause or propriety of this contradiction.

See Michaux, Elliot, Nuttal, Eaton \&c. for the species; but I may present a better view of them divided into six sub Genera.

I. Evotrium Raf. Polygamous. Calix 5 fid, petals 5 , stamens 8 , fruits smooth flowers in racemes, leaves lobed, A. Striatum, 2. A. spicatum.

II. Sacharodendron Raf. Polygamous. Cal. 5fid bearded, no petals? Stamens 6 to 10, fruits smooth, flowers fasciculate, leaves lobed. 3. $\boldsymbol{A}$. sacharinum, 4 A. barbatum, 5 A. nigrnm, 6 A. circinatum Pursh glabrum Torey.

III. Chinotrox (old name) Polygamous. Cal. petaloid smooth 8-12 parted, no petals, stamens 4 to 6 , with a globular gland at the base of each, fruits smooth, flowers agregate with a scaly involucre, leaves lobed. 7. A. rubrum, and the Var. Coccineum Mg.

IV. Eriocarpum Raf. Polygamous. Cal. mem- 
branous 5 toothed, no petals, stamens 4 to 6 without glands, fruit hairy, flowers glomerate, leaves palmate or angular. 8 A. dasycarpum, and a N.Sp. from Oregon.

9. A. virgatur Raf. many stems and branches virgate, leaves on long petiols, rounded angular crenate acute.-Mentioned by Lewis and Clarke as a small white maple, bark white: perhaps arother Var of A. circinatum, but our white maple is the dasycarpum. Seen dry, without flowers.

V. Negundo or Negundium Raf. 1808. Dec. Beck. Dioical, without complete flowers. Cal. minute 4-5 dentate, no petals, anthers 4 to 5 sessile, fruit smooth, flowers racemose pendulous, leaves pinnate or ternate. 10. $A$. or $\mathbf{N}$. fraxinifolium, leaves ternate and pinnate, folioles unequally dentate, the last trilobed.-11 A. or N. Trifoliatum Raf. fl. Tex. 8. Jeaves ternate, folioles ovate oblong entire, smooth, acute, the last 3dentate.-In Texas and Arkansas, branches green, flowers 4androus. Seen dry. figure Autikon rare. Ic. N. Sp.-12 A. or N. lobatum Raf. leaves nearly simple, triparted or trilobed, sublaciniate. Apalachian Mts. Seen alive. figure Autikon rare. Ic. N. Sp.

VI. Sphendamus Raf. (old name) Dioical, Cal. 6 parted, no petals, stamens 9 , long hairy, fruits hairy? flowers in erect racemes, leaves digitate. 13. A. macrophylum Pursh. leaves digitate hairy beneath, segments trilobed, repand dentate. In Oregon, and another N. Sp. or Var. 14. A. Palmatum Raf. leaves wide palmate, 5parted, smooth, segments 3 or 5 fid, lobed and dentate. On the R. Oregon. leaves

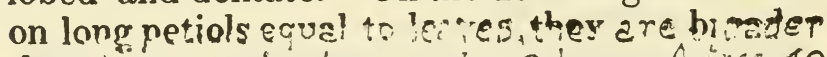
than lons, 12 inches Wide 8 long. A irge 40 feet high. Seen dry. figi k. N. ipp. 
By Hooker account the Sphendamus or $\boldsymbol{A}$. macrophylum has Cal. smooth oval, 5 petals obovate, 10 Stamens hairy at base, flowers yellow fragrant. He has properly described the A. circinatum and it must form a 7 th Subgenus, as follow.

VII. Antadenium Raf. flowers corymbose trioical polygamous. Cal. כfid hirsute, $\tilde{5}$ petals crisp linear, rarnose disk, 5 glands opposite to petals and one pistil in fertile flowers, 8. Stamens and 2 pistils in sterile fiowers.

Our Maples present then many anomalies in their fluwers, and are only united by their two winged fruit. They form now a peculiar family, akin to the rraxinus. 'These Sections will soon become as many Cenera of it ; they must be compared with the European and Asiatic Sp.

ACER-O'TIS Raf. 1817 meaning Ears without horns, bad because compound of 2 other genera, a tree and a bird: Same as ACER-ATES Eiliot 1820 (no horns) quite as bad, derived from Acer, and there is another Aceras besides among Orchidea, 3 mistaken names! $I$ have changed mine to Otanema, which See

ACHANIA Aiton and correct botanists, Malva-viscus! of Cavannilles, Nittal and other incorrect botanists, as if a Sp. of Malva Differs from Hibiscus by berry 5seeded. Not in Eaton.

1. A. malvaviscus Ait. Hibiscus do $\mathrm{L}$. Louisiana and 'Texas.

2. A. Mollis Ait. In Florida. Both seen alive in gardens.

3. A. Floridana Raf. Malva-viscus do Nuttal. Horbaceous, hirsute, leaves cordate ovate crenate in short petiols, peduncles nod- 
ding.-In Florida, small leaves and flowers, near to $A$. pilosa. Seen dry.

ACHILLEA. Well known natural Genus, which has been increased to $7 \mathbf{N}$. American species.

1. A. millefolium. L. the common yarrow or milfoil, see my medical flora : our American Sp. is not introduced, it has been deemed peculiar by some botanists, having stronger medical properties, and it has produced several varieties. that are becoming species! All in Autikon.

Var. rosea, with rose colored flowers.

Var. carnea, flowers of a pale flesh color.

Var. pumiln. Dwarf, 4 to 6 inches high.

Var tenuifolia. Leaves nearly glabrous, with slender well divided segments, almost pectinated.

2. A. Gracilis Raf. fl. texensis 12. Stem slender stiated. leaves remote, narrow smooth, lower petiolated recurvate, pinuate, folioles narrow laciniate, corymb small glomerate.-In Arkansas and Texas, only 6 inches high, fl. white.

3. A. ptarmica, doubtful, seen by few botanists, undescribed: perhaps same as 7 .

4. A. seracen, near gracilis, differs by leaves mucronate pilose.

5. A. lanulosa Nuttal. A. tomentosa Pursh not Wildenow nor Hooker. Silky, segments crowderl, corymb composite. In Missouri and Oregon.

6. A. aspienifolia. Pursh, known by obtuse segments.

8. A. Multiflora Hooker. Ptarmica Richardson. Stem erect, leaves long lanceolate serrate pinnatif, segments serrulate, nearly smooth, corymb composite, rays very short. In North Canada. Is it the ptarmica of Newyork? 
ACHLYS Dec. Hooker. Leontice triphyla Smith, certainly a peculiar genus. Cal. o. Cor. o. Many naked stamens around a naked pistil, anthers bilabiate bilobe, stigma sessile oblique concave, fruit monosperm. Put by Hooker next to Leontice, by Dec. next to Jeffersonia, unlike either except in habit and anthers. Nearer to Diphylleia, differing by the many naked stamens.-A. triphy! a Dec. H. Radical leaves with long petiols, 3 sessile folioles flabellate, reticulate, repand sinuate: Scape with a spike of white flowers. Perennial. N. W. America.

ACHRAS sapota I. said to grow in South Florida and Texas: see medical flora vol. 2

ACHYRANTHES, Our Sp. of this Genus appear to form a peculiar Genus indicated by Elliot, see Steiremis. 'The genera akin Gomphrena, Illecebrum, Celosia are yet in great eonfusion like this; see Adoketon, Pliglepidum, Xerandra of mine, and Philoxerus.

The A. repens of Elliot was a Gomphrena of Linneus.

ACMELLA Richard. nemepta Raf. Neng. 33. Differs from Heliopsis by Perianthe simple, or nearly so. The seeds in both are obovate, and truncate without teeth: leaves opposite, flowers peduncled, autumnal, yellow rays, disk blackish.

I. Subgenus. Errota, Raf. Perianthe 12 segments, rays 5 to 12 tridentate, seeds compressed, sub4gone, chaff obovate. Creeping plants annual?

I. A. Rerens Persoon \&c. Anthemis do. Walt. Spilanthus do, Mx. Well described by Elliot. Creeping, leaves oval-lanceolate toothed, trinerve, peduncles lorig axillary terminal, ravs about 12.---In Carolina. 
2. A. nutraliana Raf. A. occidentalis Nuta]. Creeping, leaves ovate crenate petiolate hardly trinerve, rays 5 to 8.-Louisiana, perianthe minute. The occidentalis of South America has the seeds terete, 5 rays, leaves large trinervate serrate, stem erect, 5 entire rays: it was the Anthemis trinervis of $\mathrm{L}$.

II. Sub. G. Helepta. Perianthe equal segments 10 to 12 , rays 6 to 12 , narrow, nearly entire, seeds 4 gone not compressed, chaff setaccous-Plants erect often simple and uniflore, leuves petiolate trinervate, Perennial.

3. A. Nudicaulis Raf. stem sulcate smooth, naked above uniflore, leaves ovate acuminate serrate, base acute, rays 6 to 8 obtuse.-In Cumberland Mts. and East Kentucky with all the following. Stem bipedal, leaves roughish above, pale beneath, flower large. Seen alive.

4. A. Flavicaulis Raf. Stem smooth striate yellowish foliose, leaves ovate acute serrate, flower nearly sessile, perianthe segments ovate obtuse, rays 10 to 12 obliqualy retuse.-Bipedal, leaves not pale beneath, flower large. Seen alive.

5. A. Parvifolia Raf. Stem smooth sulcate, leaves crowded at the base. small ovate acute serrate, flower peduncled, rays 6 to 8 retuse notched.-Pedal, small leaves and flower, segments of perianthe lanceolate acute as in nearly all. Seen alive.

6. A. Lanceolata Raf. Stem rough sulcate foliose, leaves lanceolate acuminate serrate, flower subsessile, rays 6 to 8 obtuse.-Over one foot, leaves thin pale beneath, flower middle size with broader rays. Seen alive.

I have united these plants to Acmella, altho' the habit is very different from the others, near- 
er Heliopsis. These 4 figured in my Autikon 11 to 14. ACMISPON Raf. Atl. jour. meaning point
hooked. Differing from Trigonella, Bucerates, Platycarpos and Lotus. Even 'Torrey said that it ought to be a genus, and Bentham unites it to Hosackia.

Calix deeply 5 cleft, vexillum and wings equal, pod stipitate smooth strait, compressed, swelled and hooked at the point. Leaves ternate, Silky.

1. A. sericeun Raf. Lotus do. Pursh, Trigonella americana, Nut. 'I'. L. well described by Nuttal, flowers axillary, solitary, subsessile. From Missouri to Carolina, rare, probably $2 \mathrm{sp}$. blended: both scen dry.

2, A. multiflorum Raf. peduncles axillary and terminal, multiflore nearly in a spike or umbel. Missouri. Is not the Carolina plant this? or a peculiar sp! Which is the Hersacria purshiana of Bentham? The trile Hosackia have pinnate leaves, pods cylindrical, keel rostratè instead of the pods.

ACNIDA of Linneus. Genus better known since Michaux corrected account, copied by all our botanists except Elliot. But the original A. canabina L. is not known to our botanists; they all mean that of Michaux. Jinneus described his species as follow.-A. canabina. Root flexuose, stem white, petiols purplish smooth, leaves pinnate velutine, folioles 5 to 7 narrow acute, spikes axillary foliose, fl. fem. cal. 2phyl. 5 styles. In Virginia salt marshes. Such a plant with pinnate leaves cannot be of this Genus. Could Linneus have described the leaves of another plant mixt with Acnida flowers? Could this be over again his Datiscu liirta found by no one since? Sir James Smith 
the possessor of the Linnean herbarium has not mentioned this curious fact.

1. A. obtusifolia Raf. A. cannubina Mx. and all his copists. Stem angular solid, leaves on long petiols, lanceolate, base acute, end obtuse, panicle of spikes foliose, bracts subsessile capsules or fruits smooth with acute or obtuse angles, (leaves lanceolate, capsules smooth with acute angles Mx.) - - In Virginia. As found further North, it has broad lanceolate leaves, obtuse entire, stem solid from 3 to 5 feet high, pyramidal, panicles foliose.Raf. Autikon. 4. Seen alive.

Var. retusa. leaves notched at the end.

Var. pumila. Stem pedal simple, leaves lanceolate.

Yar. procera. Stem much branched, 5 feet high.

2. A. Salicifolia Raf. 1817. Stem solid, angular above, leaves on long petiols, narrow lanceolate mucronate, panicles foliose, capsules granular $\tilde{\mathbf{5}}$ unequal angles obtuse tuberculate.From Long Island to Ohio near streams. Stem annual 2-4 feet high, leaves like willow.-Raf. Autikon 5. Seen alive.

3. A. RTSOcarpa Mx tab. 50. Stem fistular angular lofty, leaves on short petiols, acute, oval lanceolate, capsules rugose with obtuse angles. The place of growth not mentioned, stem thick, 6 to 8 feet high, leaves acute at both ends.

4. A. ellioti Raf. A. cannabina Elliot. Stem subfistular, slightly angular, leaves on long petiols, ovate lanceolate, subcrenulate, acute ; panicle naked, capsules with 3 to 5 angles obtuse or acute, slightly rugose-Banks of streams in Carolina and Florida. Stem 4 to 8 
feet high, leaves $\mathbf{2}$ to $\mathbf{5}$ inches long, petiols 1 to 3 inches. 'The only sp. found by Elliot who was doubtful about it.

ACONI'TUM. This singular natural genus of all the botanic $\mathrm{l}$ writers, is far from being well understood: we see by Decandolle and Smith that many doubtful species exist! and that our A. uncinatum is a triple species! many kinds grow in Oregon as in Niberia, and I am able to present some of them.

A. uncinatur L. Smith. Elliot. Stem nearly twining downy, leaves smooth, base truncate, 3 to 6 lobes 3dentate, 3nerve acute, flowers clustered, pedicles ramoses lax downy, 2 oblong bracts, hood unguiculate convex rostrate, wings round hairy 3 to 5 capspules.-This is the original linnean sp. described by Smith in Sup. to Rees Cyclopedia, from the linnean herbarium, and the specimen sent by Bartram, collected in the Alleganies, not near Philadelphia as stated by L. Smith quotes the figure of Curtis Mag, 1119. The flowers are large violet color. known to few botanists. The description of Elliot appears to agree.

2. A. scandens Raf. Stem climbing very lofty, leaves trifid, flowers small in axillary panicles-At the peaks of Otter in Virginia, merely indicated by Pursh as a variety, but quite distinct : growing 9 feet high.

3. A. Flexuosum Raf. Smooth, stem erect flexuose, leaves palmate 3 or 5 fid, lobes rhomboidal lanceolate acute, hood conical rostrateHigh Mts. Unaka of Carolina, flowers blue. A. uncinatum of Michaux and Eaton.

4. A. Truncatum Raf. Stem erect flexuose smooth multiflore, leaves glaucous beneath, broadly truncate at the base, trilobe, lobes ob- 
long acute, entire or bifid or $\mathbf{2 - 4}$ serrate peduncles divaricate ebracte $\mathbf{2 - 4}$ flore, hood convex lower petals ciliate outside-In West Kentucky and Illinois, pedal, upper leaves nearly sessile, lobes nearly entire at right angle, flowers small on pedicels, violet purple. Seen alive. Autikon 3. Perhaps the real type of A. flexuosum and A. divergens.

5. A. Divergens Raf. Smooth, stem nearly twining with divergent branches, leaves coriaceous deeply trilobed, flowers terminal $\mathbf{3}$ to $\mathbf{4}$, hood conical, spur inclined twisted, capsules 3-In mountain swamps of the Alleghanies, flowers large purple, leaves with 3 equal lobes-A. uncinatum Dec. Torrey, Beck. A. volubile Muhlenberg.

6. A. cornatum Raf. Smooth, stem erect flexuose, nearly simple ; leaves on long petiols cordate palmate, 5 lobed, clefts acute, lobes unequal oblong broad and bifid or trifid acute mucronate : flowers terminal on long pedicels 2 to 5 , hood convex conical, petals elliptic, capsules 3-In Ohio and Kentucky in rich woods; about one foot high, flowers large deep blue: very rare. Undescribed till now, sent to Europe by me as the $\boldsymbol{A}$. uncinatum of my florula Kent. Seen alive 1818.

Var: Biflorum, semipedal, 3 leaves, 2 flowers. Cumberland Mts. Figurès, Autikon rar. 1-Icones n. sp. 1.

7. A. Napellus L. Said by Muhlenberg to grow in Virginia, and by Hooker to grow in $\mathrm{O}$ regon. Bartram found it in his travels in Florida, but he meant probably another sp. Ours undescribed as yet.

8. A. Fischeri Reichenberg. ill. ac. 22. $A$. nasutum Fischer, Spr. Hooker, Eaton, Seringe 
Leaves broadly laciniate, raceme paniculate, hood conconical, spur bent, nectaries erect-In Oregon and Kamskatka, different from the A. nasutum of South Europe.

9. A. oregonsense Raf. Smooth erect, segments digitate, 5 parted, segments pinnatifid, narrow acute; fls. racemose erect, hood conical very obtuse, spur strait-In Oregon, stem simple 1 or 2 feet, flowers large blue 5 to 10. Compare with $\boldsymbol{A}$. kelleri of Siberı. Seen alive in gardens.

Figures, Autikon rar. 2.-Ic. N. Sp. 2.

10. A. Delphinifoliun Decandole. Stem erect downy above; leaves with many pinnatifid segments, raceme few flowered, hood convex acute.-On some Islands of the $\mathbf{N}$. W. Coast. Stem 6 to 20 inches high. Called var. Ainericanam, and two other var. deemed varieties of $A$. napelluc, by Hooker.

ACORUS, well known Genus, which I have increased to 6 speeies. I. A. verus of Asia.2. A. gramineus of China. 3. A. Europeus in med. fl. page 2, with three American species.

1. A. Americanus Raf. med. fl. fig. 1. Leaves and scapes broad gladiate, scape longer; spadix submedial lateral, capsules oblong acute.From Canada to Missouri and Virginia. Estival, 2 or 3 feet high.

2. A. Floridanls Raf. A. calamus Elliot \&c. Leaves broad gladiate longer, scape shorter, triangular, one side concave, summit gladiate; spadix near the end, stamens exserted capsules oval obtuse.-Florida to Carolina.Scape only one foot high, fl. vernal.

3. Flexuosus Raf. fl. tex. 29. Leaves graminiform narrow shorter, scape longer flexuose triangular, one side concave, end like leat; spa- 
dix medial.-Texas to Tennessee, dwarfish, one foot high, vernal. Autikon rar. Ic. n. sp. ACROANTHES Raf. 1818, Dexvaux 1810. Microstylis Nuttal 1818! Beck 1833! Lindley Gray... Malaxis sp. Michaux and authors. Ophrys Lin ... A very distinct Genus by habit and flowers, ascertained by me since 1802 , named and desrribed tein years before Nuttal's subgenus, since made a Genus, by others who have neglected to restore my previous name, meaning uncolored flowers.

Orchidea with bulbose root, stem with a medial sheathing leaf, raceme with bracts and scattered minute green flowers.-Sepals narrow connivent, the two inner narrower; lip erect cuculate, dilatate: Column minute bearing 2 anthers terminal annexed. Gray says one anther with 2 cells and 4 pollens. Nuttal said 2 unequal anthers, one with a single pollen! which must be by abortion. Capsules globose, often abortive.

1. ACr. laxifrora Raf. unifolia 1808.Malaxis unifolia Mx. ophioglossoides Pers. Microstylis ophioglossoides N. Beck \&c.Stem harly angular, leaf ovate subcordate acute raceme oblong and lax, peduncles filiform ; sepals linear, inner filiform, lip emarginate toothed in the middle.-From Newyork to Carolina, rare, Estival, in shady groves under trees.Stem 6 to 10 inches high, flowers greenish.Seen alive 1802. Figures in Pluk. alm. 435. f. 4 and my Autikon 41. Ic. rar. 60.

2. Acr. obtusifolia Raf. Scape angular, leaf cordate elliptical obtuse, raceme lax elongate, peduncles filiform ; sepals oblong, inner linear, lip furcate or hastate, toothed in the middle.-In Alabama, and Georgia, probably the 
plant of Elliot. My specimen is $\mathbf{1 0}$ inches, the leaf large and broad, sheathing the stem, which has two other sheaths at the base, bracts small squamiform round. Autikon 42. 1c. 61 .

3. Acr. acuminate Raf. Microstylis brachypoda Gray. Stem triangular, two angles winged, leaf ovate (acute?), raceme elongate slender, pedicels short adpresssed; sepals oblong inner linear, lip hastate, trilobe, 2 lobes rounded middle one acuminate.- Shady swamps of Oneida and Herkimer in New York. Estival, stem 2 to 6 inches. Deemed akin to the next European sp. by Gray; which I add to show the distinction.

Acr. Cilifolia Raf. Ophrys cilifolia \& $O$. monophylos L. Malaxis Persoon, Microstylis Lindley. Stem triangular, leaf ovate acute ciliolate, raceme slender as long as stem, pedicels short patent, sepals ovate, inner lanceolate lip entire concave acuminate.-Swamps of Prussia and the Alps. Perhaps two sp. are even blended here; but I have no materials to distinguish them properly: let the European botanists do so; but restore my genus Acroanthes 1808 adopted by Desvaux.

ACROSTICHUM, this linnean genus is now distributed into 14 Genera, since Smith and Wildenow reform of the ferns! Woodsia, Schizea and Wondwardiu belonged once to it! the A. lanceolatum is become the Nephrodium acrostichoides of India, not ours, both of $\mathrm{my}$ genus Synotelis. His A. platineuron is our Asplenium ebeneum. His $\boldsymbol{A}$. polypodioides is our Polypodium incanum-A. ilvense is Woodsia A. orealatum is Woodwordia-A. lineatum Mg. is Schizea Pusilla? 
Our only sp. left in it has even probably been mistaken for another.

1. A. maritimum Raf. A. aureum Mx. Pursh Pinnate, smooth, pinnules stipitate oblong entire obtuse or acute.-Sea shore of Florida, large fern, unfigured as yet, compare with next again.

2. A. aureum L. (Bogs of Antilles, often figured) gigantic fern 5 to 10 feet high, pinnate, pinnules sessile cuneiform oblong oblique obtuse, veins reticulated. The Ongpi of Sumatra united to this, is a third sp.

ACTAEA Linneus united thereto sp. with capsule instead of berry, other botanists have united Cimicifuga with it, having many capsules! a double blunder. The real Actaeas have a real berry, not opening. We have two sp. distinguished by me since 1802 ; but Muhlenberg prevented me to publish them, because both deemed then var. of Actea spicata: while Bigelow has published them since as peculiar. The blue berry species is the Caulophylum.

1. A. RUBRA Raf. Big. brachypetala \& americana of others. Petals acute shorter than stamens, last leaf trilobe, berries red. Deep woods from Canada to Kentucky, and Carolina.

2. A. Alba Raf. Big. Beck. pachypoda Elliot. Petals truncate longer than stamens, last leaf ovate, berries white, 5 seeded on thick peduncles often white also.-Canada to Carolina. Leaves in both bi-triternate, flowers white vernal, see med. fl. Seen alive. Autikon.

Actea racemosa see Botrophis serpentaria. ACTINEA Jussieu or Actinella of Persoon, adopted by our botanists, being identic with $\boldsymbol{A c}$ tinia a genus of animals, was changed by me to Ptilepida 1817, which see.

ACTIMERIS Raf. mispelt Actinomeris by Nuttal, who proposed it. Well distinct from all 
the akin genera with winged stems, and my Cauloma that has naked seeds. It has even 2 subgenera, and Anomeris is quite distinct.

I. Oliglosis Raf. Perianthe uniserial, rays 2 to 3 , seeds marginate, alternate leaxes.

1. A. squarrosa N. Coreopsis alternifolia L. Leaves scabrous, lanceolate serrate-Canada to Florida : several varieties; but the Alba without rays, is a peculiar Genus! Anomeris.

Var. procera, tall, 6 to 10 feet high, flowers paniculate. Coreopsis procera Aiton.

Var. pauciflora, stem simple, few flowered, leaves lanceolate serrate.

Var. serrulata, Stem simple few flowered, leaves oblong lanceolate serrulate.-the $A$. pau ciflora Nutal, hardly distinct from the last.Kentucky and Florida. All seen alive. Autikon.

The A. alata N. of Mexico, with opposite leaves is probably congeneric with Verbesina siegesbecicia my G. Anomantha.

II. Megactelis Perianthe biserial 10 to 12, seeds hardly marginate, leaves alternate sessile, Perhaps belonging to my G. Cauloma.

2. A. helianthoides $\mathbf{N}$. Leaves lanceolate acute serrate, hairy beneath, flowers coarctate, perianthe linear lanceolate rays 9.-Ohio to Louisiana. Seen alive.

3. A. Ellioti Raf. A. heïanthoides, E. Stem and leaves scabrous, ovate lanceolate serrate acute, flowers corymbose, perianthe oval, rays 10 to 12.-Georgia and Alabama. Stem 2 to 4 feet, terete winged, Seen dry.

ACTISPERMUM Raf. misspelt Actinospermum by Elliot, from Actinea! Balduina multiflora $\mathbf{N}$. differs from Balduina by perianthe biserial not imbricate, perianthe with 6gone 6toothed cells, pappus simple starlike. 
A. multiflorum Raf. Smooth, multiflore, leaves alterne sessile linear, perianthe acuminate. Florida \&c. Well described by Nuttal and Elliot.

ADELIA of Michaux and Brown, not of Linneus, is Borya of Wildenow 1805, and Persoon, not Labillardiere 1804, yet adopted by our botanists; but changed to Bigelowia, by Smith 1820, not of Raf. 181\%. What a jum ble of blunders! yet must be changed again or united to my Nudilus which see.

ADENARIUM Raf. 1816, Dec. Differs from Arenaria, by having large glands interposed between the Stamens and a different habit. Honkenya of Erhart, not of Wildenow. Another genus Adenaria of Kunth since, must also be changed to Decadenium, Raf.

1. A. peploides, Raf. Arenaria, do. L. Suffruticose, leaves fleshy ovate acute subserrate.-Europe, Sea shore, seen dry.

2. A. Maritimum Raf. Holosteum succulentum L. Arenaria peploides of Amer. botanists. Herbaceous dichotome, leaves fleshy ovate obtuse entire petals obovate--Atlantic shores of $\mathbf{N}$. America from New England to New Jersey, in sand, flowers white, vernal, terminal and in forks. Seen alive. Nuttal refers to this, the American Holosterm of L. who must have mistaken the glands for trifid petals, but he says leaves elliptic. Figures Autikon. Ic. n. sp.

ADENOCAULON of Hooker, N. G. near Tussilago, differing by naked seeds without pappus. A. bicolor, stem glandular, leaves cor date subtrilobe angulate dentate. From Oregon. Akin to Acmella, differing by want of chaff in the phoranthe.

ADENOGYNA Raf. 1825. Type the Saxi- 
fraga sarmentosa of Japan, introduced into N. America, and spontaneous in Kentucky.Genus very distinct by petals unequal, 2 lower longer, pistil glandular. See my monograph of Saxifraga genus and tribe, including N. Gen. Hemieva, Ditriclita, Steiranisia, blended with Saxifraga by Hooker, altho' as good genera as his Eriogyna and Leptarhena.

ADIAN'THUM PEDatem Raf. Med. fl. tab. 2., the only Sp. well known to all botanists.

ADIKE Raf. 1815, An. Nat. ancient name of some Nettles. A very peculiar Genus distinct from Urtica, by perfect smoothness, and pellucid stem and leaves, bearing in N. America the peculiar names of Richweed, Coolweed, and Clearweed, never nettles. My name misspelt Adesin by Eaton! I had spelt it Adicea, I now restore the original Greek name of Dioscorides.

Monoical, Calix similar in both, 3partite, sepals linear thick obtuse or cylindrical, erect. Stamens 3 elongate no nectary. Fertile fl. with persistent calix, a sessile capitate stigma. Seed ovate compressed-Habit annual, stem erect thick, leaves opposite petiolate serrate, very smooth, trinerve, flowers estival in axillary and dichotome corymbs, Sometimes a fourth part added; but the Genus does not depend so much on number as the consimilar peculiar calix.

1. Ad. pumira Raf. Urtica pumila L. stem filiform dwarf, base naked, leaves ovate obtuse, lower entire, upper deeply crenate-serrate with an obtuse point, margin subciliolate, petiols shorter than leaves: corymbs pauciflore short. In the Alleghany Mts. and near Philadelphia at Manayunk. Stem 2 to 5 inches, pellucid round 
leaves small, flowers few. Linneus says in $\mathbf{C a}$ nada Aquosis, stem digital. I have found his real sp. unknown to many botanists who mistake the next for it.

Var. 1. Minima, biuncial, few leaves on short petiols. Figures, Autikon Raf.

3. A. glaberima Raf. Med. fl. (Urtica pumila, Mx and all our botanists except Elliot.)--r Stem round fleshy pellucid; leaves on long petiols, oval acuminate, lucid, serrate: corymbs dichotomous multiflore.-The most common species all over the U. States, 'stem one or two feet high, thick often diaphanous! leaves large extremely smooth.-Var. ramosa, stem and corymbs branched.-Autikon $R$ af.

3. A. lanceolata Raf. (Urtica pumila Elliot) stem obtusely quadrangular, fleshy and branched; leaves on long petiols, lanceolate acuminate, serrate, with some hairs above; corymbs multiflore, some recurved.-Stem pedal branching from the base. In Carolina, Elliot's description is original; but his diagnosis borrowed to make it agree with the last.

4. A. RHombordea Raf. Stem round dwarf, branclied at the base; leaves on long petiols, ovate rhomboidal or subdeltoid, base entire, end with obtuse point, sides crenate serrate not ciliolate; corymbs multiflore often foliolate and recurved.

In Kentucky, rare, stem 6 to 8 inches, near to $\boldsymbol{A}$ pumila, but larger stem and leavès, petiols equal to leaves except on branches. Seen alive.-Figure, Autik. Raf.

ADLUMIA Raf. 1808, Dec. Beck. Noticed as a genus as early as 1804 in the garden of the collector Adlum, and also in the Alleghanies at Peter's Mt. only indicated in 1808, since well 
established by Decandole and begining to be adopted. Very distinct from Corydalis by Corolla bigibose by 2 spurs as in Dielytra, but 4 petals spungy and coalescent, persistent over the pod.

A. cirrhosa R. D. B. Fumaria fungosa Aiton, $\boldsymbol{F}$. recta Mich. Corydalis of many botanists. Scandent cirrhose, leaves decompound, racemes laxiflore axillary.-In the Alleghanies from Mattawan Mts. to Apalachian Mts. Perrennial.

Var. rupestris. Trailing on rocks, leaves cespitose.

Var. elatior. Trailing up trees 10 feet high, leaves remote.

Var. alba \& rosea, with white or rose flowers instead of usual pale incarnate. All seen alive.

ADNARIA Raf. fl. lud. probably a subgenus of the Codurolla or Vacciniums with bell flowers, which see.

ADOKETON Raf. Mus. N. Sc. 1. Akin to Lahayea, distinguished as follows-petals entire, stigma trilobe, capsule few seeded.

Lahayea misspelt Hagea by Persoon (dedicated to Lahaye) has petals emarginate, stigma entire, capsule polysperme.

Both have Cal. 5 ph. 5 petals, 1 style, capsule unilocular, trivalve, trigone, seeds central. Leaves opposite.-Nat. family of Dionidia.

1. A. Uniflorum Raf. Stem uniflore, leaves ovate minute, calix and petals acute equal,On the summit of the Unaka Mts. of $\mathbf{N}$. Carolina, one inch high, flower white vernal. Seen dry, Ic. n. sp.

2. A. Saxatile Raf. Mus. Nat. Sc. Illecebrum alsinefolium Scopoli. Stem multiflore, leaves oval acute, calix segments hooded, petals 
longer oblong obtuse, capsule 6 seeded-Rocks of Mt. Gallo near Palermo, and in Spain. Seen alive in 1812 , described $181 \%$.

1 ADONIS. Decandole has reformed this genus, the two linnean sp. being the type of two sections, the annual having 6 to 8 petals concave, style strait: the perennnial (Consiligo) 8 to 15 spreading flat petals, style hooked.

A. Riparia Raf. (A. autumnalis of N. America, wrongly deemed exotic) stem ramose striate, leaves glaucous crowded tripinnate multifid, pinnules crowded linear, end trifid acute flowers terminal, solitary sessile, petals 6 to 8 concave round.-Margins of streams. West Kentucky to Louisiana, pedal, annual, flower scarlet, base darker spotted. Real native. Autikon.

A. autumnalis of Europe has stem slender, leaves short, remote, flower pedicellate, petals obcordate, and grows in fields.

ADORIUM Raf. fl. Miss. Marathrum Raf. 1819, N. G. 22, this name was very good; but Dec. having a Hipomarathrum which must become Marathrum, I have changed it for greater accuracy. Both were Greek names of umbelliferous. Humboldt has also another Marathrum.

It differs from Seseli by involucres, involucels 5 leaves unilateral membranous, calix 5toothed, petals ovate acuminate involute, fruit oblong, angular striate. Leaves opposite, many sterile flowers.

1. A. crassifolium Raf. Seseli divaricatum Pursh, Nuttal. Branches divaricate, leaves thick pinnatifid, peduncles rigid.-On the $R$. Missouri. Well described by Nuttal, fl. yellow ver- nal. Seen dry. Figure in my Autikon rar. 
ADOXA moschatelina L. said by 'Torrey and Hooker, to grow in boreal America and the Oregon mts. undescribed. My specimens from Europe. Genus near to Panax and Aralia.

ADVENTINA Raf. Radiate. Perianthe globular 5 phyle, Sepals connivent equal ovate acute. Phoranthe flat chaffy. Rays 5 fertile, equal small and opposed to sepals, ligules short trilobe white, ovary and seed shut between the sepals and internal palea or chaff, similar to sepals oblong and thus bivalved, style very short bifid, pappus paleaceous multifid. Floscules of the disk minute yellow complete, chaff lanceolate flat, corolla tubular 5toothed, stamens and style inclosed, pappus campanulate multifid.Seeds black oblong compressed bivalved in rays, oblong terete in disk. Leaves opposite, flowers terminal.

1. PARviflora Raf. Stem slender branched diffuse smooth, leaves petiolate ovate acute angular dentate, lower rounder, upper nearly sessile and entire; flowers terminal lax-Growing spontaneous for several years in the orchard of Bartram's Garden, come with seeds from the South. Annual, Estival, pedal. Leaves thin smooth, flowers vcry small, white rays hardly exserted. Very different from any known genus, nearest Achillea, but habit calix and seed unlike. Named after its adventitious production near Philadelphia. Probably a Florida plant. Seen alive.

Figure Autikon 5, and Ic. n. sp. 5.

2. A. Ciliata Raf. Stem thick pilose, trichotome and dichotome, leaves petiolate ovate serrate ciliate, flowers in forks or terminal subcorymbose-Found with the last, but in a different 
place and season: smaller, but flowers larger, Autumnal, annual, $\mathbf{6}$ to $\mathbf{1 0}$ inches high, hardly ramose or nearly simple. Messrs. Carr owners of Bartram's garden cannot account for the spontaneous production of these plants and several others in their garden.

Figure Autikon 6. Icon. n. sp. 6.

I must conclude here this beginning and model of a proper Lexrcon of our N. American Flora. To continue the whole Flora even in this concise form, would fill several large volumes. This specimen contains about $\mathbf{4 0}$ articles and Genera, whereof many are new, and includes nearly 150 species, whereof many were undescribed.

North America, excluding the Mexican States contains probably 2000 Genera and 10,000 species of trees and plants, exclusive of the Cellular or Cryptogamic plants; but including Palms, Grasses and Ferns, Shrubs and Vines.. Our Botanists know or admit of hardly more than one half. Botanical Works are filled with plants neglected by them, because rare and little known. Our Herbals or Botanical Collections contain a crowd of plants as yet unnoticed and undescribed. Baldwin's Merbarium has been a Botanical mine for 20 years past, for Elliot, Nuttal, Torrey, \&c. and will continue so a long while. Nuttal will soon increase the Oregon Western Botany by perhaps 1000 N. Sp.Whoever applies to the proper study of a single Genus or family increases or doubles our knowledge of it. Torrey has lately increased our Cyperacea alone to 25 genera and 326 species and he has not exhausted this tribe; but omit- 
ted many genera and synonyms.

Meantime my own Herbarium and Autikox contains about 1200 New Genera and New Species discovered and collected since 1802, but chiefly from 1815 to this time; and whereof but a small part has been published or indicated as yet. It is therefore to these that I must apply myself at first in order to make known my discoveries and labors with the hidden wealth of our Flora. I shall however at the same time give many discriminating monographs of Families and Genera, to elucidate their critical and correct knowledge.

The New trees and Shrubs of North Ameriica which $I$ have discovered and ascertained might form a separate volume; but I may arld them if practicable. As I have stated already, arrangement is of little consequence now in botanical works ; since every botanist changes the serial order, by misunderstanding the real steps of nature in organized vegetables. If I was to offer a very elaborate series of real corrected NATURAL ORDERS as I did in 1815, they would be deemed improper by those who now begin to dabble in them, and give us jumbled families without peculiar essential characters, and without proper names, as they constantly go on to do the same with Genera and Species.

I seldom was able to publish a botanical work exactly as I wished in the proper style and plan. I can only collect and afford new materials, observations and criticisms for better times or moods. Yet my actual labor, is as much a Flora as that of Michaux or Pursh, since it includes more new discoveries, and may only pass over the wellknown and settled plants. But whenever doubts or disparities occur, they will deserve 
my attention and critical investigation. The 40 articles of this Lexicon have already proved how many striking mistakes and palpable errors of Linneus, Michaux, Pursh, Hooker, Nuttal, Beck, Eaton, Torrey, Elliot, and others exist undetected and unnoticed by our writers and compilers. At this rate the 2000 Genera will afford 5000 similar blunders.

It is a weary and ungrateful task to revise errors; but it must be done: Since every exposed error is equal to a discovery. I shall not even spare my own, as we are all liable to them, and we improve by age and experience. If all would be as careful and as liberal as I am, the science might soon cease to be involved in hidden groups of neglected genera and species, or in useless synonyms of mistaken plants, and improper names.

Meantime in order to name properly my new American plants, it has been needful to study over again and revise many Genera and Natural families; since several are yet in utter confusion, by the usual practice of Botanists to refer plants at random, and without attending to the actual character's, to force them into genera where they do not belong.

This arduous undertaking was indispensable, and has led me to revise, reform, divide and fix several natural families and a crowd of genera ; but such a labor altho' connected with our American Botany, applies nevertheless to the whole Globe, and has become my Synopsis Flora Telluriana, or synoptical Mantissa of 2000 New Genera, Species, Orders, \&c., which will be the companion to this North American Flora, and the complement of my Botanical researches.

Being in hope of obtaining the Herbarium of my late friend $\mathrm{Z}$. Collins, which contains many 
new and rare plants collected by himself, besides Kin, Boyken, Baldwin, Nuttal, Elliot, Ware, Leconte, Schweinitz, \&c., from Florida and Arkanzas to Labrador, I may find there additional materials for this Flora; therefore, the delay that may occur in the publication of the numbers, will be compensated by the additional new plants I may be able to describe.

I shall either continue to give monographs of some remarkable or rich genera, beginning with Kuhnia, Gentiana, Lechea, Hypericum, \&c., or I may give series of new Species from interesting localities.

I may also pay particular attention to our New Genera, many of which are improperly referred as yet to akin Genera.

As to the Natural Orders of our Plants, my general views and examples have been given in my preface, and will be found in the Introduction to the Flora Telluriana.

It is again recommended to our Botanists to study well the natural affinities and disparities of Grenera and Species, both of which they have often heretofore either neglected or overlooked. 


\section{NEW GENUS OLSYNIUM.}

A very fine New Genus from Oregon, has been blended with Siryrinchium by the English Botanists, which I have called Orsveıum, meaning hardly united, It differs by the Corolla campanulate, the long fiee stamens only united at the base, 3 stigmas \&c, and belongs to the same natural family of G ALAXIDIA, distinguished from IrIDia by stamens not quite fiee.

OLSYNIUM. Corolla of 6 petals campanulate, each oblong, striate. Stamens 3, filaments free and subulate, base contracted above the united base. Style elongate, stigmas 3 acute. Ovary and fruit as in Siryrinchium. Roots fibrose, leaves sheathing, spatha bivalve, biflore.

Olsynium grandiflorum Raf. Siryrinchium grandiflorum. Douglas in Bot. register 1634. Bot. magazine 3509. Stem compressed, leaves shorter, acute, spatha unequal margin membranose, flowers twin drooping deep purple.

A lovely and graceful plant, discovered at the falls of Oakanagan on the Oregon River. It is hardy, flowers vernal large, nearly two inches, but never spreading flat as in Siryrinchium. 


\title{
NEW FLORA OF NOR'TH AMERICA.
}

\author{
M O NOG R P H \\ OF THE GENUS KUHNIA, \\ WITII REMARKS. \\ BY PROF. C. S. RAFINESQUE. \\ OCTOBER 1836.
}

This curious Genus has appeared to puzzle many Botanists, the species being rare and $\mathrm{l}$. cal, have been seen by few of them, and they have often copied each other, or mistaken those seen. Sir James Smith has given a good account in Rees Cyclopedia, of some old blunders about it ; but many more remain to be detected : the original linnean species having again been found on the very spot where Dr. Kuhn probably procured the specimen he took to Linneus, affords the opportunity to do so, and to notice at the same time the other kinds discovered by Elliot and myself.

Dr. Adam Kuhn was but a poor botanist and hardly deserved to have such a fine Genus named after him: he has written nothing; but only gave the first linnean Lectures in North America. It appears that he did not even find himself the first Kuhnia, but it was brought to him, and he had the only merit to take it to Linneus, who flattered by having a Student coming to him from Pennsylvania, and struck by the anomaly of the Stamina, dedicated the same to him as a new Genus. Schoepf has written that having applied to Dr. Kuhn to know the locality of the plant, he could not tell, not 
having found it himself. Meantime Gaertner having proved that the chief linnean distinction of separate stamina was wrong, since the plant he described as the same, bad syngenesious stamina : the Genus became fixed by the striking character of plumose seeds, and well distinguished by it from Eupatorium; but he wrongly called it Critonia, mistaking it for a Critonia of Brown, which Smith states to be the Eupatorium dalea, with scabrous pappus. All the sp. of Eupatorium have more or less such a scabrous or dentate pappus. The alternate leaves are no character of the Kuhnia since I have found a species with opposite leaves, and the very Kuhnia of Linneus has sometimes such leaves below.

The plant of Gaertner tab. 174, who only figured the seeds, has been made since a second Sp. of the Genus, and called Kuhnia critonia ; but I shall show by Wildenow and others presently, that it is by no means positive that he was mistaken, since the original Kuhnia of Linneus, offers sometimes on the same plant the characters of both species; Ventenat and Persoon unite both again.

Sir James Smith regreted that these plants were not introduced as yet in the English Gardens. In Loudon Cyclopedia of plants they are not mentioned as introduced in 1829, being omitted. Yet in the second edition of Sweet Hortus Brittanicus, published in 1830, I find 3 species mentioned as introduced, the $K$. eupatorioides in $1812, K$. critonia in 1816, and $K$. rosmarinifolia in $182 \%$. But they must be very scarce, and they had not been figured yet in the magazines, nor elucidated by English Botanists. 
Ventenat united to this Genus the Eupatorium canescens of Ortega, a plant of Cuba, and called it $\boldsymbol{K}$. rosmarinifolia; he was followed by Persoon in this.

Michaux perhaps never saw this plant since he does not mention their locality nor distinction and has only one Critonia Kuhnia which no one can prove to be Gaertner's. Muhlenberg never saw these plants alive and ascribes to both white flowers. Pursh meantime gives yellow flowers to $\boldsymbol{K}$. critonia, but quotes no locality. Wildenow's account appears to be made up of Linneus and Michaux account, making 2 Sp. of them. Lamark copied Linneus and his fig. tab. 26 is $K$. eupatorioides. Poiret has copied Michaux and Ventenat.

W. P. C. Barton in his flora philadelphica 1817, states to have found the linnean plant on the rocks of the Schuylkill $\mathbf{R}$. above Lemonhill; but Nuttal in 1819 ascribes that very same locolity for the sp. K. critonia: and it is there also that in 1836 has been found by Mr. Durand and myself the Linnean plant, which I suspect to be identic with that of Gaertner.

It is said that the Eupatorium alternifolium of Sibiria, figured by Arduin, is also the same plant, and Sir James Smith could find no difference in the specimen sent by Arduin to Linneus. Yet is very strange that the same plant should grow near Philadelphia and on the Altaic mts. of Asia, and hardly any where clse : since it is not in the Flora of Hooker and therefore does not extend to Canada, nor the central and western parts of North America. Nor is it found in the floras of Louisiana and Missouri. Therefore the Sibirian plant must again be 
compared with ours, and will be found different, in fact Lamark has noticed some difference in it. Torrey in 1826, and Beck in 1833, in their floras of the Northern States have both the I.innean and Gaertnerian species, but have never found them growing wild, since they quote no locality, but merely copy the characters of other authors, stating Pennsylv. and Virginia, as the native place of both. Beck besides ascribes pale yellow flowers to K. critonia, as Pursh (but Torrey says white) and Torrey a pubescent stem. But all the species with whitish flowers, turn yellow in drying, and a pubescent or glandular Stem belongs to many: while Smith describes his as smooth; but this varies on the same plant.

In $1818 \mathrm{I}$ discovered in Kentucky a narrow leaved sp. which I mistook for the K. critonia; but have since found very different from the $K$. critonic of Elliot 1824, who is the only one that has described it properly; but his plant is even probably different from Gaertner's : while my plant is perfectly distimct by the fulvous pappus, stated to be white in all the others; I called it K. media in 1833 but K. fulva would be a better name. I found it in 3 localities of Kentucky and even on the banks of the Ohio.

In September 1823 in my visit to the falls of the R. Cumberland, in the Wasioto hills of East Kentucky, a beautiful botanical spot visited by no Botanist but myself, I again detected another sp. of Kuhnia, quite distinct by opposite elliptic short leaves. I named it K. elliptica, and it is described in 1833 in my Herb. Rafinesquianum.

Elliot has 3 Species of Southern Kuhnia in the 2 d volume of his flora of Southern States 
1824, and all appear to be new, his K.critonia is that of Mx. probably and nearer to K.rosmarinifolia, yet distinct, and I named it K. tuberosa in 1833. His K. eupatorioides? deemed doubtful by himself, altho' very near the Iinnean Sp. is somewhat peculiar, and perhaps distinct, it is my K. dasypia. It is from the prairies of Alabama. There also grow his $3 \mathrm{~d}$ Sp. K. glutinosa, a new sp. which I possess and is quite distinct. It has been adopted by the compiler Eaton, with the other usual 2 sp. in 1833 in his manual of Botany, 6 th edition, who never saw any of the plants; he ascribes with Pursh to K. critonia, pubescent and petiolate leaves!

Few of these botanists appear to have taken the trouble to consult the original description of Linneus, Arduin and others, and thus they ascribe the characters at random, The original Eupatorium alternifolium had Stem terete pubescent, leaves lanceolate, petiolate, decurrent, triuncial, rough: corymbs multiflore compact, calix striate. This is the Siberian plant of Arduin tab. 20. But Linneus in his last edition decribes the K. eupatorioides with Stem rigid and branches in the middle smooth, leaves alterne subpctiolate broad lanceolate serrate rugose, uncial, upper ones linear lanceolate entire; corymbs small; which agrees perfectly with the plants found near Philadelphia in 1836. Yet he refers to it the above disparate plant of Arduin, and also the figure of Plukenet 87. 2 ! best figured in his son's decads tab. 11. Meantime the plant of Gaertner is described by Smith with entire leaves, linear lanceolate and corymb paniculate pauciflore.

Yet Michaux's plant (with Gaertner's name) 
is pubescent, leaves linear lanceolate, commonly entire, punctate beneath, flowers paniculate.

All these disparities evince that this fine anomalous and rare Genus has been misunderstood and improperly described by nearly all the botanists. Now at last in 1836, the original Linnean and Kuhn's plant having been found wild on the very identical spot, whence carried to Linneus, many specimens collected, of several varieties growing together, and roots, seeds and specimens sent to England by Dr. James Mease : the original species will become better known. Meantime I presume that the following comparative view of the Species actually known will be acceptable to the Botanists and Horticulturalists.

These plants altho' not very conspicuous, are not destitute of beauty, by their elegant shape and plumose seeds. They are all hardy perennials with thick roots; they blossom in September, and assume their feathery appearance in October.

1. K. eupatorioides L. (Critonia of many authors), exactly as described by Linneus : only add, root brown perpendicular with lateral fibres, lower leaves trinerve, subpetiolate or base attenuated, 1 or 2 inches long, a few are opposite sometimes, stem terete striate, whole plant covered with minute glands mistaken for pubescence by some; perianthe striate glandular, flowers pale yellowish white, pappus white. Rocky banks of the R. Schuylkill near Philadelphia, in a single spot near the rail road bridge: 3 varieties 1 Pyramidalis tripedal, lower leaves lanceolate, entire at both ends, branches and corymbs pyramidal with entire narrow leaves. 2 var. corymbosa. Stem simple, leaves 
narrow lanceolate, somewhat serrate in the middle, flowers in a multiflore compound corymb. 3 Var. angustifolia, stem simple pedal leaves linear lanceolate entire, flowers in a simple pauciflore corymb. 'These 2 last are probably the Critonia of Gaertner and others, yet they are perhaps nothing else but various ages of the plant? but since they have been mistaken for species, they must be properly noticed.

2. K. altaica Raf. If the Sibirian plant is distinct as probable, it may be distinguished by Stem really pubescent, leaves triuncial alterne rough decurrent, lanceolate base not attenuated. This is Eup. alternifolium Arduin tab.20, and Linneus in first editions.

3. K. dasypia Raf. eupatorioides Elliot. Stem branched pubescent, leaves alternate, lanceolate unequally serrate, glandular punctate, triuncial, rough above, pubescent beneath; flowers paniculate white, pappus white. Meadows of Alabama and Georgia.

4. K. glutinosa Elliot, glutinose pubescent, leaves lanceolate alterne sess. serrate laciniate, upper entire; flowers corymbose panicled. Meadows of Alabama, well described by Elliot, who sent me a specimen. Stem bipedal, branched, viscose glands mixt with hairs all over.

5. K. elliptica Raf. discovered 1823 described 1833. Stem striate pubescent, branches and leaves opposite, leaves sessile smooth,elliptic uncial, serrate in the middle, glandular beneath, flowers whitish in lax multiflore corymbs, pappus cinereous-Falls of the $\mathbf{R}$. Cumberland, 3 feet high; very handsome species. The K. glabra of my monograph 1833 which I mistook for the linnean sp. is only a variety of this with stem smooth, leaves subpetiolate, flowers less lax. I found it in the Alleghany mts. on the 
Monongahela in 1825. Var. montana.

6. K. tuberusa Raf. 1833. K. critonia Mx. and Elliot exclus. Syn. Root tuberose, stem virgate striate pubescent; leaves alternate sessile linear entire, pubescent, margin revolute, flowers paniculate white, exterior sepals of the perianthe reflexed, pappus white.-In Carolina, dry soils, well described by Elliot but under a wrong name.

7. K. fulva Raf. disc. 1818 descr. 1833 as K. media : entirely smooth, stem striate virgate, lower leaves opposite, upper alternate, all sessile linear lanceolate entire, long pale beneath and not glandular; flowers paniculate yellowish, pappus fulvous-On the banks of the Ohio and hills of East Kentucky, about 2 feet high, leaves 3 inches, down or pappus very peculiar by its color. I sent my $2 \mathbf{N}$. Sp. to Decandole; but have not yet seen the 5 th volume of his Synopsis. I possess yet several specimens of 1, 5 and 7 to furnish to botanists, and they are figured in my Autikon. and Ic. rar.

8. K. pubescens Raf. mon. Entirely pubescent, stem virgate striate, leaves subpetiol. lanceol. nearly entire, punctate, fl. paniculate, pappus fulvescent-Seen dry, said to grow in the mts. Alleghany, perhaps only a variety of the K. tuberosa, or fulva or K. eupatorioides; but the down was not white in the specimen: probably mistaken by many for the 2 usual species, whence the difference of descriptions. I deem the color of the down truly essential.

9. K. rosmarinifolia, Vent. Pers. \&c. Leaves canescent linear lanceolate semiamplexic. very entire, margin revolute, peduncles terminal uniflore, fl. purple, pappus white? In Cuba, compare it with K. tuberosa; but the flowers separate them. Eup. canescens Ortega dec. 34. 
MONOGRAPH OF AMPHTCARPA AND AKIN GENERA. OF THE GROUP TETRODES.

G. AMPHICARPA Elliot. T'Te Genus Glycine of Linneus, a strange medley of species without common characters, is now divided in many Genera requiring yet discrimination and revision. As early as 1804 I had proposed to Muhlenberg the Genus Tetrodea for Gl. monoica, comosa, subterranfa, having a tubular 4toothed calix, and I indicated this G. in 1808. But in 1818 Elliot established with them his $G$. Amphicarpa, which has been generaly received. Decandole wrongly spells it amphicarpea. but as each of these $3 \mathrm{sp}$. may be the type of a peculiar Genus, I shall now revise it and add several sp.

Amphicarpa Calix tubular sub campanulate, base obtuse or gibbose, 4 teeth acute subequal. Petals equal oblong keel obtuse, wings 1 toothed vexillum adpressed or incumbent. Stam 9-1. Stigma capitate. Pod stipitate, oblong, compressed acuminate by the style, 3-4 seeds subreniform. Sometimes the lower flowers solitary wilhout petals nor stamens, perfect $f$. racemose and bracteolate, Perennials.

Lовомоn Raf. calix campanulate, base acute, unequaly 4toothed. Petals and stamens as above, but commonly apetalous flowers dioical or monoical, with 5 minute sessile united anthers. Pod flat semi ovate acute, without style, one side strait, 2 seeds lenticular. Annuals Flowers axillary, not racemose, no bracts. (Name ancient.)

Geolobus Raf. calix campanulate, 4 fid, upper segment notched. Petals unequal, keel and wings oblong, vexillum obovate striate notched. 
Pod compressed round acute, one seed lenticular, Peduucles biflore bibractate, flowers yellow, pods hiding in the ground. which the name implies. Annuals.

The 3 Genera have twining or flexuose stems, and stipulate trifoliate leaves, roots creeping flowers estival.

1. Amphicarpa villosa Raf. Gil. comosa? L. \& . . . Twining, stem and leaves hairy, folioles subequal ovate oblong acute soft, the lateral obliqual: racemes short 5-9flowered, bracts ovate acute striate, calix hairy-In Alabama and Mississipi. Folioles uncial equal to petiols, flowers white tipt with purple. Linneus having only said of his Gl. comosa, leaves hirsute, racemes small lateral, flowers blue, seeds with purple spots: it is impossible to identify it. Torrey, Beck and Elliot omit it; while Nuttal deems it the real type of Gl.monoica. My descriptions and specimens will fix my sp. to which 1 give new names to avoid ambiguity.

2. Auph. crliata Raf. stem twining filiform round with reflexed hairs, leaves on long petiols, smooth but ciliate, folioles unequal, lateral sessile obliqual trapezoidal, medial petiolate rhomboidal rounded acute: raceme elongate equal to petiols, peduncled and multiflore, bracts obovate obtuse biflore, calix smoothApalachian Mts of Virginia and Carolina, disc. 1825, flowers white, very distinct species.

3. Amph. heterophyla Raf. monoica Nuttal. Stem twining filiform angular with reflexed hairs, leaves on short petiols variable but shining scabrous and ciliate, subequal but either ovate lanceolate acute or else ovate elliptical obtuse: raceme elongate, multiflore, bracts rounded striate, calix smooth-In the Alleghany mts. of Pennsylv. flowers white. 
4. Ampir. Elcioti Raf. monoica Elliot. Gl. monoica? L. stem twining angular with reflexed hairs, folioles ovate lanceolate subequal,thin, acute, scabrous above, petiols long: racemes pendulous commonly sterile, calix hairy gibbose. Pods of imperfect flowers ovate one seeded-In Carolina, Virginia \&c. Flowers white and violet. Doubtful sp. yet, since Elliot says in diagnosis leaves glabrous, and in description hairy! He confirms the existence of imperfect flowers in racemes, cultivated for these pods like Arachis, but Linneus says these subterranean flowers are solitary! It would be hard to say what Michaux, Pursh, Torrey, Hooker, Beck, Eaton \&c mean by their monoica, which they do not describe, blending 4 or $5 \mathrm{sp}$. under that false name; most of them have all the flowers perfect and fertile.

5. Амpн. Deltifolia Raf. stem twining with reflexed hairs, petiols short, folioles scabrous ciliate ovate deltoid, lateral obliqual, medial rhomboidal: racemes short equal to petiols, erect pauciflore, bracts ovate acute striateFrom Canada and Missouri to New Jersey, the most common kind and probably the monoica of many botanists, but without imperfect flowers; all with whitish petals, although many are abortive several Var. 1, Incarnata, 2 procera 8 feet high \&c.

6. Ampir. cuspidata Raf. stem twining angular hairy, hairs patent fulvous, petiols very long, folioles ample ovate cuspidate nearly smooth, lateral obliqual : racemes elongate ramose, racemules 3-4flore, bracts ovate obtuse striate, equal to pedicels, calix smooth-Mts. Cumberland of East Kentucky, disc. 1823. Leaves large 3-4 inches, petiols 6-8 inches: flowers small, white. 
All these plants are called Pea-Vines or Binders, and are much relished by cattle. They entwine over plants and shrubs, in woods and among rocks. All in my Autikon. Their blossoms are estival.

7. Lobomon acutifolium Raf. Twining quite hispid, hairs adpressed, folioles equal ovate acute, glaucous and reticulate beneath : peduncles filiform 1-3flore, bracts ovate lanceolate, calyx smooth, pods pubescent-Ohio, Illinois \&c : flowers minute monoical or dioical, commonly apetalous, sterile sessile, but fertile and pods with pedicels.

8. Lobo sarmentosum Raf. Glycine do $\boldsymbol{W}$. Amphic. do Elliot . . . . Twining glabrous, folioles ovate acute, peduncles filiform triflore, calix villose, pods smooth-Carolina, flowers all apetalous and seeds grey, spotted with black.

9. Loв. obtusifolium Raf. Pilose, hairs spreading, twining stem, folioles ellipticel obtuse or retuse, cuspidate glaucous, some ovate or rounded: flowers sessile, calix hirsute, pods sessie geminate pubescent-In Kentucky \&c, monoical, flowers apetalous, upper ones sterile, 2-3axillary sessile.

10. Lob. montanum Raf. Glycine montana Raf. atl. Journ. Dioical, smooth, stem erect flexuose, folioles ovate acute; peduncles uniflore, pods and calix smooth-On the rocks of high hills in the Alleghanies of Pennsylvania, Juniata and Sherman Valleys. Only semipedal and root annual.

The fecondation. of these plants is a problem, and their apetalous structure a great anomaly. All in Autikon except 8. "They form a peculiar group Tetrodes Raf. by their curious anomalies, with Amphicarpa and the 2 next foreign plants. 
11. Geolobus flavus Raf. Glyc. subterranea L. Stem procumbent flexuose, petiols erect trigone, folioles oblong obtuse smooth: peduncles axillary drooping biflore, two bracts ovate incumbent over the 2 flowers-In South America and perhaps Florida?

I must add here for further discrimination another fine N. G. united as usual to Glycine, and akin to the above.

Triendilix Raf. calix 4 fid closed, only 3 petals concealed within it. Pods linear terete polysperm. Perennial, twining, peduncles axillary, flowers minute.

12. Triendilix clandestina Raf. Glycine do W. Pers ... stem twining, villose silky, folioles lanceolate, silky beneath, peduncles ternate uniflore-In Australia. Leaves with 3 folioles as in all the true Glycine tribe. Triendilix means three within the calix, abreviation from Triendokilix, Geolobus means Earthpod. Lobomon is an ancient Greek name for some kind of peas er beans.

\section{MONOGRAPH OF PELTANDRA.}

I noticed this Genus as early as 1804, I ascertained it in 1816, and published it in 1819 in my Essay on $50 \mathrm{~N}$. G. in Journal de Physique Paris. It has been adopted by many Botanists; Torrey doubted it in 1817, yet in 1821 he has admitted but misnamed it Lecontea, a double blunder, slnce there was another Lecontea! and my previous name was better. Beck in 1833 changed it again through ignorance of my previous claim to Renselaria. Each knew only of one type, while I have ascertained many: 
they had been blended in Arum and Caladiım. The whole tribe of Aroides was in utter confusion; but is rectified in my Flora Telluriana.

PELTANDRA Raf. meaning shield stamens, 1819. Arum L. \&c Calla Mx. Caladium Elliot, Lecontea Torrey 1824, Renselaria Beck 1833.

Spatha narrow involute tubulose, side split spadix inclosed quite geniferous, terete obtuse, pistils inferior, stigmas sessile capitate. Anthers confluent (sterile at the end of the spadix) peltate crenate multilocular on the sides. Berries globose unequal 1 to 5 ovate seeds. Scapose leaves simple commonly cuspidate, root tuberose.

Remarks. This Genus includes several aquatic plants or growing in damp soils and meadows, while the other Aroides commonly avoid the Waters. They may be known by this peculiarity even out of bloom, as also by the cuspidate leaves. The berries are green and contaia a jelly with commonly several seeds. but often one only by abortion. Those seeds were eaten by the Indians, even the leaves are edible when boiled; the roots are thick, and tuberose, but not properly turnip like as in other Aroides. The flowers are vernal, and last only a few days in May or June, they do not bloom every year. Michaux reduced them to Calla that has mixt flowers and a style, because one sp. has a flat spatha as Calla; this may form a Sub Genus.

Leucospatha, Spathe cuculate, end dilatate, 4 to 5 seeds-Peltandra, spathe involute, end narrow, 3 to 5 seeds.

Renselaria, Ditto, Ditto, 1 or 2 seeds. 
1. Peltandra undulata Raf. 1819. Petiols equal to leaves striate dimidiate, leaves sagittate nndulate oblong cuspidate lobes oblong obtuse, scape striate terete punctate of black, spatba subequal, base inflate, split in the middle, margin undulate, end narrow involute. In the Alleghany and Mattaw an mts, also in New Jersey \&c, it flowers in June, spathe lucid blackish green, margin yellow, spadix white, young petiols glandular, leaves 5 to 10 inches long. This was the type of my Peltandra having 3 to 5 seeds. It is hard to say which Authors have seen that species but blended it with the next. It was probably the real Arum Virginicum of Clayton and Linneus.

2. Peltandra canadensis Raf. Arum sagittatum foliis elongatis, Charlevoix pl. canad. fig. 81. Arum Virginicum of many botanists, Lecontea virg. Torrey. Renselaria virg. Beck.

Petiols elongate terete not punctate, leaves oblong flat hastate cordate, cuspidate, lobes obtuse: scapes several subcarinate, spatha lanceolate involute, margin undulate-In Canada, New York, New England and Pennsylvania. This is the type of Renselaria having only 1 or 2 ripe seeds, easily known by flat leaves semipedal, long petiols not dimidiate \&c.

3. Peltandra latifolia Raf. Pefiols short dimidiate flat above, leaves broad triangular sagittate, undulate cuspidate, lobes divaricate obtuse; scapes several terete incurved, berries often one seeded-In the waters of marshes, ponds, creeks, in south New Jersey and Delaware, leaves often one foot long and broad: not rare there, but seldom found in flowers. It belong to subgenus Renselaria, but is quite dis- 
tinct from the last. The $\boldsymbol{P}$. Walteri is very akin, but has acute lobes.

4. Peltandra heteroplyyla Raf. Petiols unequal terete, leaves variable oblong cuspidate, or ovatoblong hardly sagittate or nearly auriculate or base often entire obliqual, lobes unequal rounded short or ovate obtuse-With the last in the same places, even near Philadelphia in the Schuylkill, but rare, seldom seen in flowers, berries 1-3 seeded, different leaves out of the same root.

5. Peltandra hastata Raf. Arum Virginicum Elliot. Petiols vaginated at base, leaves equal in length oblong, hastate cordate acuminate, lobes subacute; spatha oblong acute repand, spadix equal.-In Carolina and Florida, it blossoms in April there says Elliot, the berries have several seeds, and thus it is a Leucospatha like the next.

6. Peltandra alba Raf. Calla sagittifolia mx. Caladius glaucum Elliot. Leaves glaucous hastate cordate acuminate, lobes oblong obtuse divaricate, petiols elongate ; scape short, spatha cuculate oval lanceolate, white, end dilatateIn Carolina and probably all over the southern States, Elliot says the berries are red and with several seeds. The white flowers and red berries will distinguish this ; they are both green in the others. This will be the type of Leucospatha and may have some other peculiar characters in the flowers to make it a Genus-Thus I have fully ascertained $4 \mathrm{sp}$. in the North and 2 in the South; but there are 2 other doubtful sp. there.

7. Peltandra Walten Raf. Arum sagittifolium Walter, Arum Walteri Elliot. Leaves triangular sagittate, angles divaricate acute. 
In Carolina, not well described, but very near $\boldsymbol{P}$. latifolia, said to be larger than $\boldsymbol{P}$. hastata with similar flower's.

8. Peltandra angustifolia Raf. Calla Virginica Var. Michaux. Leaves hastate cordate narrow oblong, lobes obtuse, spatha elongate incurved-Virginia \&c, in this sp. Michaux has blended probably the sp. 1,2 aud 4, but the narrow leaves and incurved spatha indicate a peculiar species.

\section{MONOGRAPH OF LECHEA.}

AND THE SUbGenera menandra, EUdieXa foc.

Linneus had only two sp. of Lechea, having reduced to that Genus the Menandra of Grovonius. His L. minor and major figured in Amer. Acad. 3. tab. 1. have been applied at random by nearly all the botanists to any other Species, till Michaux who added $3 \mathrm{sp}$. and Wildenow $L$. verticillata of India, which I doubt to be of this Genus, as it appears to be strictly North American. I shall now increase it to $21 \mathrm{sp}$. and divide it into 3 subgenera that might perhaps become as many Genera.

The essential characters of this Genus were also widely mistaken. Linneus put it into triandria trigynia, altho' the stamens vary from $\mathbf{3}$ to 12 , and there are not 3 styles, but a single trilobe sessile plumose stigma! The Capsule is not one seeded as stated by most of Authors, unless sometimes by abortion; but it has 3 or 6 seeds: nor is that capsule 3locular nor with double valves as stated by others, it is strictly unilocular, with 3 free placentas mistaken for valves, or partitions. The calix is not single 
as stated, but commonly double, the outward of 2 sepals, being mistaken for bracts, altho' they persist in the fruit, and are quite similar to the extra sepals of the Cistidian tribe to which this Genus evidently belongs, notwithstanding the reduced stamens and seeds. This Genus is in fact so neer to Anthelis (Helianthemum T.) that the main distinction consists only in $\mathbf{3}$ petals instead of 5 , and it is supposed that the original L. major of Lin. was also his Cistus canadensis! or a variety of it!

Characters of LECHEA if kept as a single Genus. Calix double and persistent, external bipartite seldom lacking,sepals narrower, internal tripartite. Petals 3 small narrow, equal obtuse and fugacious. Stam 3 to 12, filiform, anthers bilobe. Stigma large sessile capitate trilobe floccose or plumose or papillose. Capsule unilocular trivalve, 3 to 9 seeds inserted on 3 small free placentas, sometimes only one by abortion. Simall annuals or perennials with terete stiff branching stem, leaves ternate or opposite scattered simple entire and subsessile, flowers estival evanescent paniculate or racemose, not yellon-Vulgar name Pinweed.

1. Menandra, Fl. Virg. of Gronovius. External calix with $\mathbf{2}$ short sepals or almost lacking. Stamens 6 to 9, seeds 1 to 3 . Leaves often ternate, and flowers racemose. Perennials.

2. Lechea, Ext. calix equal in length to the internal. Stamens 6 to 12 , seeds 1 to 3. flowers spicate paniculate, some stems sterile.

3. Eudiexa Raf. (well 2 external) Ext. calix longer than the internal. Stamens 3 to 6. Seeds 3 to 9 . Chiefly annuals. 
The mistakes about these plants have arisen from few Botanists seeing their anthesis or full bloom, which like many Cistides, only last a few hours towards noon: the petals soon after wither, and the stamens collapse or are glued to the stigma. But the characters now assumed on the persistent respective length of the calix, will always be perspicuous. I have specimens of all the described species.

\section{MENANDRA.}

1. L. Pulchella Raf. quite smooth, stem stiff virgate, leaves scattered long linear acute; flowers paniculate and lax in naked racemes, bracts none, ext. sepals subulate, internal ovate obtuse, petals elliptic obtuse incarnate, capsule obovate.-In the Pine barrens of New Jersey, probably extending South; probably the $\boldsymbol{L}$. racemulosa of many Botanists, but not Mx. which is pubescent with ciliate leaves. It is a very pretty sp. when in full bloom in August, the calix being red inside, the petals incarnate the large stigma white. The erect stiff stem produces hundreds of flowers at once, it is about one foot high, and only branched above. Several varieties 1. Minor, only 2 to 4 inches high, panicle leafy. 2. Elegcins, over a foot high, panicle fastigiate. 3. Pyramidalis. Branches pyramidal.

2. L. cinerea Raf. (L. thymifolia Mx. \&c) adpressed pubescent,cinereous fastigiate, leaves scattered narrow linear adpressed; racemes paniculate pauciflore subnaked, flowers canescent outside, sepals lanceolate acute, capsule oblong longer.-In Florida and Georgia : deemed $\boldsymbol{L}$. racemulosa by Collins, easily known by its color, perhaps the real thymifolia?

3. L. Ternifolia Raf. (Menandra ramis ter- 
nis, Gronov.) Stem paniculate above, adpressed pubescent, leaves and branches mostly ternate cuneate acute ciliate nearly smooth ; racemes paniculate lax nearly naked, peduncles elongate, capsules oblong-In Virginia, New Jersey and probably elsewhere. This must be the real L. racemulosa of Mx. who quotes Gronovius. Pedal, calix colored of red as in $\boldsymbol{L}$. pulchella.

4. L. Furfuracea Raf. Pubescent pulverulent, stem erect. branches fastigiate above, leaves narrow linear scattered nearly obtuse; racemules terminal naked,pedicels unequal,ext. cal. subulate very short, internal rounded, capsules globose-ln Kentucky and Illinois, 6 to 10 inches high. ftowers greenish oatside, with a yellow furfle. Nearest to L. cinerea, easily known by the mealy pubescence and globose capsules.

5. L. LAXIflora Raf. smooth, stem erect paniculate, branches lax, leaves scattered linear cuneate acuminate ciliate ; racemes scattered lax, flowers remote naked, pedicels elongate, calix and capsules ovate-In New Jersey Pine Woods with L. pulchella, to which akin, difference in leaves chiefly, flowers green not red outside. Var brevifolia semipedal, fl. redish, leaves shorter more cuneate hardly ciliate.

6. L. Tenurfolia Mx. Eiliot or L. verna Raf. L. juncifolia Walter) humble dumose pilose, stems assurgent, branches spreading, leaves scattered subulate linear, racemes paniculate divaricate; flowers remote axillary solitary, capsules globose large-said to grow on the $\mathbf{R}$. Santi of Carolina, and to blossom earlier than any other in Aprii and May, no external calix according to Elliot, yet very near to some $\boldsymbol{E}_{z_{i}-}$ diexa with long ext. calix. 
7. L. Recurvata Raf. Hispid assurgent, branches opposite and ternate, leaves broad oblong acute at both ends ciliate; racemes spicate recurvate unilateral, peclicels very short, sepals oval, capsules globose-In Carolina and Virginia, akin to L. ternifolia (perhaps the true Menandra of $\mathrm{Gr}^{\circ}$.) leaves and fruit different, calix redish, seeds convex and concave.

\section{LECIIEA OR LEKEA.}

8. L. Mucronata $R$ af, precis 1814. villosa Elliot 1820, major of Walter and Mx not Lin. -Villose, stem erect, sterile stems prostrate, leaves opposite and ternate below, chiefly lanceolate, mucronate, on short petiols ; flowers in compound spikes axillary to foliaceous bracts, ext. sepals acute reflexed in anthesis, internal sepals obtuse, capsules ovate villose.-From New England to Carolina, the most common sp. but not the lirnean L. major with leaves rough above, tomentose beneath and scattered flowers; which is the real Cistus Canadensis! Flowers subsessile,ext. sepals linear, adpressed in the fruit, internal sepals lanceolate, petals lanceolate obtuse, commonly 3 seeds oblong acute with an angle inside. Several varieties 1. Simplex my original sp. stem nearly simple, leaves oblong cuneate, bracts oblong. 2. $R a-$ mosa, branches spreading above, leaves ovate lanceolate, bracts lanceolate. Original specimen sent me by Elliot from Carolina. 3 Sessiliflora, leaves lanceolate, petiols very hairy, branches fastigiate, spikes axillary and short, flowers sessile. From Missouri. All perennials.

9. L. heterophyla Raf. L. minor Smith. stem paniculate above, adpressed pubescent, 
ieaves commonly ternate, lower obovate, subsessile, upper cuneate and linear petiolate acute smooth; racemes panicul. lax subnaked, pedicels equal to $\mathrm{fl}$. Internal sepals lanceol. acute carinate, capsules ovate-Kentucky and 1llinois in woods and glades, trigone, ext. sepals subequal linear. Several varieties, 1 major, 2 minor, 3 parviflora, lower leaves caducous, flowers small fuscate. It has no sterile stems. Perennial.

10. L. glonerata Raf. smooth, branches short adpressed, leaves variable oblong, lanceolate or cuneate, petiolate mucronate; flowers axillary and terminal on short pedicels, glomerate, sepals ovate acute carinate, capsules subglobose-Apalachian mts. pedal, no sterile stems, calix trigone over the fruit, external sepals linear-Perennial.

11. L. conynbosa Raf. stem erect rough, above pilose corymbose, leaves petiolate broad oblong nearly obtuse, pubescent, ciliate ; flowers corymbose, pedicels equal to flowers, sepals round concave, ext. linear, capsules globoseMts. Alleghany, 6 to 12 inches high, leaves small, capsules large with 3 to 6 seeds, discovered 1818.

12. L. surculosa Raf. stem with spreading branches, sterile stems prostrate pilose, with leaves ternate ovatoblong acute ciliate petiolate branches smooth with leaves opposite and alternate smooth linear ; flowers paniculate, pedicels equal, bracts subulate, ext. sepals linear, internal ovate acute, capsules ovate-In Pennsylvania on dry hills, the L. minor of some Authors, stem 3 to 6 inches, leaves and flowers small.

13. L, Revoluta Raf. minor of Lin. not of 
Smith nor other Authors. Stem erect, branches opposite and ternate, leaves 3-4nate or opposite, lower ovate, upper linear lanceol. scattered petiolate, smooth above, pubescent beneath, margin revolute, flowers paniculateFound by Kalm in Canada woody glades. This description is taken from Limneus altogether, and agrees very well with some specimens I have from the Alleghanies of Pennsylv. the flowers are small, the capsules ovate \&c, Smith says L. blended others with this.

14. L. VIrgata Raf. stem simple virgate pubescent, leaves scattered or 2-3-4 nate mixt, petiolate linear cuneate ciliate acuminate; racemes axillary short pauciflore, pedicels equal to fl. sepals ovate acute carinate, external linear, capsules ovate.-In the Allegh. Mts. pedal, var. 1. Breviflora, semipedal, lower leaves oblong, short, racemes very short 2-3flore. 2 Bracteata pedal, lower leaves oblong, racemes longer than leaves, base foliose; end 5-7flore. The sp. 9, 10 and 14 with carinate trigone calix deserve perhaps to form another subgenus T'ropendria Raf.

15. L. Floridana Raf. smooth, diffuse ramose, branches filiform, leaves scattered, minute linear, racemes paniculate pauciflore naked, pedicels long unequal, sepals and capsules ovate-Found by Mr. Ware in Florida, small subdichotome, few leaves and flowers; habit of Eudiexa, but the ext. calix equal in length, tho' narrower as usual : probably annual.

EUDIEXA.

16. L. secundiflora Raf. smooth, stems diffuse paniculate, leaves scattered lax narrow linear, racemes subspicate, flowers remote se- 
cund, pedicels short, ext. cal. double of the internal linear, internal silky lanceolate, capsules ohlong-Discorered 182:3 in the glades of West Kentucky, rare, $\mathbf{6}$ inches high, small flowers, petals white oblong obtuse, stigma red, 3 oblong seeds in the capsules. It blossoms in June and July. Annual. Is it L. thymifolia Smith? which is an Eudiexa! certainly not that of $\mathbf{M x}$. neither have the leaves like thyme.

i7. L. PAuciflora Raf. adpressed pubescent stem liumble diffuse ramose, leaves scattered, slender,linear cuneate, imbricate rather obtuse, flowers few scattered extraxillary, pedicels short, sepals smooth, external a little longer, capsules globose-Near the Sea Shore in Long Island and New Jersey, small plant only $\mathbf{3}$ inches high, it blossoms in July. Annual.

18. L. Bunvifolia Raf. adpressed pilose, branches fastigiate, leaves scattered petiolate short, lanceolate or oblong ciliolate mucronulate; racemes erect, bracteoles linear lanceol. flowers secund, pedicels equal, ext. sepals not much longer, capunles ovate-Mts. Apalaches, semipedal, very distinct sp. by petiolate short leaves. Annual.

19. L. vnifiora Raf. Smooth, stem slender angular with few leaves, above naked, subuniflore, leaves scattered adpressed narrow linear cuneate; sepals membranaceous, ext. sepals oblong obtuse not mich longer, internal ovate obtuse, capsu!e globose about 6 seeded-Summit of the Alleghany Mts. of Naryland, disc. 1825 , only 3 or 4 inches high, only 5 or 6 leaves and 1 or 2 flowers. Capsule commonly with 6 oval seeds.

20. L. Stellata Raf. Pilose, stem erect nearly simple, leaves 3 -4nate petiolate elliptic 
mucronate. upper leaves alternate lanceolate: racemes foliose, pedicels shorter, ext. sepals very long, capsules ovatoblong-New York and Ohio, often mistaken for L. villosa, pedal, estival, sepals linear and ovate.

21. L. Sessiliflora Raf. adpressed pilose, branches diffuse virgate, leaves scattered, spreading, petiolate, linear ciliate acute ; flowers axillary subspicate or glomerate sessile,ext. sepals linear not much longer, internal lanceolate. In Florida and Alabama, near to $\mathrm{L}$. pauciflora, main difference leaves petiolate ciliate acute. Near also to L. floridana, but flowers sessile.

It would have been difficult to designate which of these plants may have been seen and blended with those of Michaux by our Botanists since Torrey, Beck, Nuttal, Pursh, Eaton, Elliot \&c seldom describe those they have seen, and never noticed the peculiar characters of the calix, capsules and seeds, on which I have chiefly based my subgenera and species; most of which are very distinct, and not likely to be overlooked again, if my characters are duly attended to, and even more sp. may be detected.

As to L. verticillata of the East Indies, it is probably a peculiar Genus, being stated to have the habit of Spermacoce, with opposite leaves elliptic serrulate, smooth above, rough beneath, and the flowers verticillate. Is it a Rubiacea with adherent ovary?

The L. chinensis of Loureiro is still more widely different, being a Commelinea! (of what Genus?) according to Smith and Dunal. The monograph of Smith in Rees cyclop, may be consulted, he has exposed the blunders of $\mathbf{L}$. and expressed a wish for a better labor like 
mine on this Genus, having only $6 \mathrm{sp}$. of it, and Dunal in Decandole 1824 has no more, he chiefly copies Elliot. We lack good figures of these plants, that with our Hudsonias chiefly represent the Cistian tribe in N. America.

If ever this G. must be again illustrated, let the monographer copy the original descriptions of all the Authors, and compare them. Mine are all original and chiefly out of living specimens.

The L. minor of Smith had sub corymbose flowers and carinate calix, being probably my L. heterophyla. That of Pursh and Dunal can hardly be identified by me : that erroneous name must be omitted. 'The $I$. major of Bigelow is Anthelis rosmarinifolia, in Decandole who makes a Subgenus Lecheoides of all our American. Anthelis, see my monographs of Hndsonia and Anthelis. (Helianthemum.)

Iechea was dedicated to Prof. Leche of Abo by Linneus, it must be pronounced Lekea and perhaps spelt so. Menandra of Gronovius might have been adopted instead, although the meaning moon stamens does not properly apply. 


\section{INDEX OF GENERA.}

SUBGENFRA AND STNONYMS OF THE LEXICON.

Synonyms are in Italics-References to the Pages.

Abalon page 33. Abama 34. Abbottia 36.

Abies 37.

Abrus 39.

Abutilon 39.

Acakia 41.

Acalypha 43.

Acanthus 46.

Acer 47.

Acerotis Accerates 49.

Achania 49.

Achillea 50.

Achlys 51 .

Achras 51.

Achyranthes 51 .

Acmella 51.

Acmispon 53.

Acnida 53.

Aconitum 55

Acorus 57.

Acroanthes 58.

Acrostichum 59.

Actaea 60.

Actinea, actinella 60.

Actimeris 60 .

Actispermum 61.

Adelia 62.

Adenarium 62.

Adenocaulon 62.

Adenogyna 62.

Adianthum 63.

Adike 63

Adicen 63.

Adlumia 63.

Adnaria 66.

Adoketon 65.

Adonis 66.

Adorium 66.

Adoxa 67.

Adventina 67.

Anomantha 61 .

Anomeris 61.

Arenaria 62.

Amphicarpa 81.

Amosa 41.

Anthericum 36.

Antadenium 49.

Anthemis 51.

Balduina 61.

Bigelowia 62.

Borya 62.

Caladium 86.

Calla 88.

Cauloma 61.

Clinotrox 47.

Coridalis 63.

Coreopsis 61.

Conradia 34.

Critonia 73.

Cupameni 43.

Darlingtonia 42.

Datisca 53.

Diadesma 41. 
Diclinotrys 33. Eburnax 42. Eriocarpum 47. Eudiexa 90. Evotrium 47. Eupatorium 73. Fumaria 63.

Geolobus 81, 85. Glycine 81 . Helepta 52.

Helonias 33. Holosteum 62. Honkenya 62. Julibrisin 41. Juncus 36. Kuhnia 73. Lavatera 40. Lechea 89. Leptilix 34. Leontice 51. Lecontea 85. Leucospatha 86 . Lobomon 81. Lotus 53. Malaxis 58. Malvaviscus 49. Malvinda 39. Marathrum 66. Melanthium 33. Megactelis 61. Menandra 90. Microstylis 58. Mimosa 42.
Narthecium 35.

Negundium 48.

Nudilus 62.

Oliglossis 61.

Olsynium 72.

Ophrys 59.

Otanema 49.

Paltrima 36.

Pedicularis 46.

Peltandra 85.

Pinus 37.

Ptilepida 60.

Renselaria 86.

Saccharodendrun $4 \%$.

Saxifraga 63.

Schrankia 42.

Seseli 66.

Sida 39.

Sisyrinchium 72.

Sphendamus 48.

Spilanthus 51.

Synotelis 59.

Tetrodea 81.

Tofielda 34.

Triantha 35.

Triendilix 85.

Tristemon 36.

Triglochin 36.

Trigonella 53.

Urtica 63.

Vaccinium 65.

Veratrum 33.

Verbesina. 61. 


\section{NEW FLORA}

\section{NORTH AMERICA,}

BY

PROF. RAFINESQUE.

SECOND PAIRT.

Neophyton.

PHILADELPHIA

1836. 



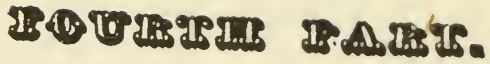 \\ NEOBOTANON.}

\section{NEW FLORA AND BO'TANY \\ OF}

\section{NORTH AMERICA.}

\section{BEING A SUPPLEMENTAL FI.ORA,}

To the various Floras and Botanical Works of Michaux, Muhlenberg, Pursh, Nuttal, Elliot, 'Torrey, Beck, Eaton, Bigelow, Barton, Robin, Hooker, Riddell, Darlington, Schweinitz. Gibbs, \&c.

Besides the great works of Linneus, Wildenow, Vahl, Vitman, Persoon, Lamark, Decandole, Sprengel, Jussieu, Adanson, Necker, Lindley, \&c. containing nearly 500 additional or revised New Genera, and 1500 additional or corrected. New Species, illustrated by figures in Autikon Botanikon.

\section{BY C. S. RAFINESQUE, A. M.-PH. D.}

Prof. of Botany, the historical and natural sciencesMiember of many learned Societies of Paris, Vienna. Monn, Bruxilles, Bordeaux, Zurich, Naples, \&c. and in Philadelphia, New York, Cincinati, Lexington, \&c.

The Floral weallh in this wide land cunceuded, $W_{\text {cll }}$ be at last by learn,ed cure rexealed

\section{P H ILA DEIS HIA :}

PRINTED FOR THE AUTHOR AND PUBLISHER. 



\section{NEW FLORA OF NORTH AMERICA.}

\section{HISTORICAL SKETCH.}

A complete history and biography of our Botanists and botanical writers, would form a very interesting preamble to a general Flora, but might be misplaced in this mantissa, besides occupying too much space. 'The history of orders, Genera and Species, or the account of their names, forms, qualities, cultivation \&c. might be a work of itself, but shall be partly attended to in the descriptive parts: the medical and economical uses of 600 medical genera, have been already detailed in my medical Flora, to which I shall add at some future period a Supplement upon 200 additional medical Genera, since ascertained or elucidated.

It was my intention to insert here an alphabetical Catalogue of all our Botanists and their works or labors; I had collected ample materials for this; but as I hope to obtain additions thereto, I will delay it for another number of this work: meantime $I$ shall be happy to receive any such information of all the Botanists who may yet be unknown to me.

In the last Century our Botanists were few and mostly foreign travellers. From 1800 to 1816 they had gradualy increased, but from 1816 to 1836 for 20 years past, I have had the pleasure to see the lovely Science of Botany gradualy spreading, and the number of Botanists greatly increased, chiefly in the North; while now this Science begins to be taught in schools, and thus acquires many votaries.

The Floras published last Century were chiefly Gronovius or Clayton's Flora Virginica, and Walker's Flora Caroliniana, both very 
superficial ; but Kalm, Bartram, Castiglione, Schoepf, Barton, Mason, Muhlenberg, Michaux, Cutler, Bosc, Kin, Denke, \&c. had then begun their researches. 'The first general Catalogue of the North American plants then known was published in 1771 by Forster ; the second by Muhlenberg in 1812: our first Flora by Michaux (editor Richard) came out in 1803, the second by Pursh in 1814; no other has since been attempted, except Nuttal's on Genera and the periodical compilations of Eaton, owing to the vast increase of materials, as Botanists began to settle themselves over the States, making the new attempt no easy task. But several local or Sectional Floras have been published that have greatly added to our general knowledge of particularly regions.

Among these must be particularly mentioned with praise.

Elliot-flora of the Southern States, under the modest title of sketch of Botany. 1816 to 1820.

Robin-flora of Lousiana, revised and improved by myself in $181 \%$.

Torrey-flora and Compendium of the Northern States, 1826.

Beck-Botany of the Northern and Middle States, 1333.

Bigelow-Flora Bostoniensis.

W. P. C. Barton-Flora Philadelphica.

Hooker-Flora of the British possessions, or Canada and Boreal America, including New Sibiria yet in progress.

Darliugton, Florula Cestrica 2 editions.

Torrey-Florula or plants of upper Missouri collected by James.

Nuttal-Florula of Origon Mts. collected by 
Wyeth, Florida by Ware and his florula Arkanzica-Besides my own florulas Mandanensis, Texensis, Oregonensis, Arkanzica, Ohiensis, Missourica, \&c. But the number of mere Catalogues has been much more numerous; they are of course superficial and full of mistaken plants or names yet they have been useful in enlarging our views of the range of plants, and the localities of the rare ones. They began last Century by Muhlenberg flora Lancastriensis, and Cutler of Massachusets full of mistakes-The principal in this Century have been.

Drayton-plants of South Carolina.

Rafinesque-Florulas Delawarica and Columbica, 1804.

Barton-Florula Philadelphica.

Torrey-Flora of New York.

Green-Catalogue of plants of the State of New York.

Brereton-Flora of District Columbia.

Mrs Gambold-Florula Cherokensis, first female Botanical writer.

Riddell---Flora of the Western States, with some new Sp.

S . .... Florula of Natchitoches.

Rafinesque-Florula Kentukensis, 1824. Short and Eaton---Catalogue of Kentucky plants.

Gibbs---Florula of plants near Colombia.

Williams---Plants of Florida.

Schweinitz---Plants of North Pennsylvania.

Bradbury---Florula Missurica.

Hooker---Florula Islandica.

Tully---Plants of New Haven, Connecticut. Muhlenberg---General Catalogue of North American Plants. 1812 and 1818. 
Eddy---Flora plandomensis in Long Island.

Croom and Loomis---Plants of Florida.

Monographs of Families or Genera are far more useful than Catalogues, because they enlarge our knowledge of Species, and make us acquainted with them. Among these I must chiefly mention Schweinitz---Fungi and Hepatica---Carex and Viola.

Torrey-On Cyperacea.

Grey---On Rhynchospora.

Leconte---On Utricularia, Ruellia.

Dewey---On Carexides nearly 200Sp. deem ed still a Genus.

Rafinesque---On Vitis. Trillium, Gentiana, Heuchera, Houstonia, Rosa, Lysimachia.

Michaux---On Oaks or Quercus.

Muhlenberg---On Willows or Salix.

Bosc---On Fraxinus. Nuttal, on Sarrazinia.

Muhlenberg, on Grasses.

Halsey, on Lichens.

Sylvas or Dendrologies are also monographs of our Trees and Shrubs ; tbey have been given by Marshall, Philadelphica 1784 .

Castiglione, in Italian $\mathbf{1 7 9 0 .}$

Vangenheim. in Germany with figures.

Michaux, in France with figures, and a late compiled translation has lately appeared in New England with wood cuts.

My New Sylva or Supplement to our Trees and Shrubs, will be additional in this work.

Iconographical Works like those of Catesby, Abbot, Lamark illustrations, the English Botanical magazines ofc. are too costly to succeed with us-Dr. W.P. C. Barton, flora of North America on this plan, could only extend to a couple of volumes and about 120 Species! His Medical Flora and that of Bigelow extended 
only to a few selected medical plants-mine has 100 wood cuts-Brereton botanical Journal, a Horticult. Journal in Baltimore, another in Philadelphia by Landreth, have only reached one or a few numbers. Audubon in his splendid work on Birds, has given many inaccurate figures of 'Trees and Shrubs, similar to those of Catesby-The best figures were those of Michaux and Pursh, but those of Hooker now exceed them still. I have published few of my own; many engraved in 1807 for me, were mostly lost before publication. I have reserved my labors in that way for my Icones rariorum yet mpt. and my Autikon Botanikon or plan of Self figures by specimens : of which Grey's Grasses is as yet the only imitation with us. A splended flora of Newfoundland was began in France, but has not been completed.

The miscellaneous or partial labors on our Botany are very numerous, including tracts, essays, descriptions of single plants \&c,. scattered in the transactions of our learned societies, Journals and periodicals \&c, to seek for them is often a task or difficult matter. Several monographs of New Genera and Species are thus scattered Jeffersonia, Heterandra, Tullya, Lophactis, Polanisia, Nemopanthes, Collinsia, Clintonia. Many may be found in Silliman's physical Journal.

Nuttal's Genera of N. America and Eaton's manual of Botany are two of the most striking and useful as general miscellanies. Eaton's has had the luck to go through several editions as a school book ; but each Edition is different, enlarged or revised; yet very defective in goneral, and lacking nearly all my new plants. 
Sevcral elements of Botany by Locke, Rich. Comstock, Sumner, Nuttal, Grey, and others have been published for the use of Schools chiefly. None have yet made us familiar with the improvements of Decandole, Richard, Agardh \&c. Lindley has been reprinted. My improvements in philosophical Botany will be recapitulated in the Introduction to my FLORA Telluriana.

My own miscellaneous works are not few, New Genera and Species, 1808 in Mitchell's Med. and Phil. repository. Elements of Somiology-Analysis of Nature-Reviews of Pursh, Nuttal, Eaton, Elliot, Bigelow \&c. Decads of new plants 1818-50 New Genera of plants 1819-Neogenyton or 66 New Genera 1825 Annals of Nature 1820.-medical flora 1828 to 1830-Atlantic Journal 1832 with $150 \mathrm{~N}$. G. or Sp.-Herbarium Rafinesquianum 1833.

Botanical remarks and novelties in the Bruxcells Annals of Science 1820-New plants in Mirror of Sciences 1814-Precis des Decouvertes 1814 \&c,. \&c.

In fact $I$ have been accused of having scattered too much mybotanical discoveries and labors; but I mean now to concentrate them in this work. Nuttal's rare plants of Florida and 83 new of various parts, with Asa Grey 4 rare plants of New York are miscellaneous labors. like mine.

Our Botanists besides writers may be divided into Collectors, Travellers, Amateurs and Horticulturalists.

Those who have written but little, or merely some sketch, are Baldwin, Croom, Thomas, Aikin, Conrad, Oakes, Peck, Houghton, Schoolcraft, Waterhouse, Locke, James, Halsey, 
Emmons, Cooper, Torrey, Leavenworth, Mitchell, Pickering, Boykin, Short, Peters, H. H. Eaton, Loomis, Cooley, Clinton, Booth, Leitner, the two brothers Green and Leconte with some others. Several are yet living and may do more hereafter.

Those who have never published any thing, altho' they collected Herbals, and were practical Botanists, are chiefly Collins, Miller, Wray, Pitcher, Hall, Vanvleck, Lyons, Herbemont, Habersham, Squib, Enslen, Boykin, Williams, Hitchcock, Hingston, Ingalls, Simmons, Griswold,Gates, Whitlow, Knevels,Steinhauer, Gaissenhauer, Durand, Griffith, Fisher, Mac Williams, with many others mentioned by Elliot, Hooker and Eaton as having helped their labors. These collectors are often very useful to the others by imparting specimens, localities and facts: their number is increasing, and several may yet become writers or improvers.

It is from such that $I$ have received much help by gifts or exchanges of specimens, new facts and observations. I have reckoned particularly among my friends and assistants, Collins, Durand, Miller, Short (2 brothers and a sister) Walton, Hall, Carr, Hingston. Mac Williams, Vanvleck, Gaissenhauer, Ward, Mease, Bradbury, Kin, Ridgely, Mrs. Holley born Austin, Hart, Crocket, Limner, Duval, Lawrence, Knevel. \&c.

But I have received also many specimens from professed Botanists, Muhlenberg, 'Torrey, Beck, Schweinitz, Elliot, Cutler, Eaton, Bradbury, Brickell, Halley. Short, Eddy छc. all American Botanists, chiefly by exchanges of my own or purchases; besides some American plants received form foreign Botanists 
Decandole, Sheperd, Haworth, Tratenick, Seiber, Moricand, Bory, Swainson, Romer, \&c.

Botanical travelers who merely come to explore our Plants in order to send them to European Gardens or Herbals, are also numerous : the fruits of their exertions are chiefly made known to us by European Writers. Such were Kalm, Mason. Michaux, Vanderschot, Castiglione, Bosc, Palissot, Turpin, Acosta, Richardson, Goldie, Drummond, Douglass, Macnab, Enslen, Lyons, Kin, Bradbury, Rustan, Berich.

Among our native traveling collectors, I must mention Bartram, Lewis and Clark, James, Schoolcraft, Baldwin, Peters, Cozen, Ware, Wyeth, Gates, Houghton, Pitcher, Walton, \&c. who have often explored far regions, and discovered many new plauts.

The distant regions of Origon have chiefly been visited by Makenzie. Langsdorf, Scooler, Douglass, Wyeth, Nuttal, Walton \&. While the Regions of Florida, have been explored by Bartram, Roberts, Williams, Cozen, Kin, Baldwin, Ware, Croom, Gates, Leitner, \&c. But both as well as Texas will afford novelties for many years to come, and I have myself many of them to describe in this Work, received from various quarters,

Amateurs as Horticulturalists, or friends of Science, or Patrons of explorers, rank also among the promoters of Botany; I may mention among those known to me or who have helped my researches, Clinton, Forrest, Mease, Adlum, Marshall, Clifford, Shultz, Carr, Walsh, Betton, Haines, Sitgraves, Mrs. Wallace, Mrs. Betton \&e: many more exist all over the United States; Stephen Van Rensalaer has been a great patron of Eaton: Maclure and Collins of various Botanists. 
Lastly general Works on Botany are indispensable to all those who wish to know well the plants of these and other consimilar regions. The works of Linneus, Wildenow,Persoon, Vitman, Romer and Shultze, Sprengel, Decandole, Lamark, Martyn, and Smith in Rees Cyclopedia. profess to describe all the known plants of the earth ; and altho' they all lack many yet, they give us the gradual knowledge of the improving Science.

In Loudun Cyclopedia of plants we find only the plants cultivated in England, in Dumont Botaniste Cultivateur those in France. In Aiton Hortus Kewensis many American plants were first described, and others are now yearly in the Botanical Register of Lindley, Bot. magaz. of Hooker.

But as many of our plants have been mistaken elsewhere, or blended with akin foreign plants, it is even often necessary for the exact Botanist to consult the original works on the plants of the Antilles, Europe, Sibiria and Japan. The floras Jamaicensis of Brown, Swartz, Lunan hortus Jamaicensis, Gmelin flora Sibirica, Thunberg flora Japonica, and the floras of England and France, must occasionally be studied to verify our plants. Many new sp. have been mistaken by them for ours.

In all these writings there is something to glean or to learn. Thus the correct Botanist has an ample field even in comparing Books, ascertaining Synonyms, similarities and divertities He must have a rich Herbarium besides or else many to study and consult. How few of our Botanists take this trouble? they prefer compiling, copying errors and misnomers. How few visit the great Herbals of Muhlenberg, Nut- 
tal, Torrey, Elliot, Schweinitz, and my own ... now either deposited in public institutions, or accessible to all. Torrey and myself at any rate, are ever ready to communicate with $\mathrm{Bo}$ tanists, answer enquiries, or solve difficulties. Botanical compilations are most useful when they include all the previous plants; but our American Compilers are always deficient, because they neglect through various motives to collect all the published information; thus the plants of Bartram, Lewis, Robin, Castiglione, Brickell, Bosc \&.c with my own, have often been omitted.

The best Herbals or Collections of our floras, are besides mine, those of Torrey in New York, Elliot in Charleston, Beck in Albany, Bigelow in Boston, Short in Lexington ..... Those of Nuttal, Schweinitz, Baldwin, and Muhlenberg are preserved in Philadelphia, chiefly at the Academy of Natural Sciences. My friend Durand is now collecting here an extensive American Herbal. That of Collins was very valuable, and is now added to mine. Others less rich in species are scattered chiefly in Boston, New Haven, New York, Baltimore, Charleston, Columbia, Washington, New Orleans, Cincinnati \&c. But some families of Plants are very rare in these Herbals, not being easily preserved, such as Palms, Yucas, Cactides, Fungides.

Few are aware how difficult it is to collect an extensive American Herbal with many rare plants ; those made in limited localities or gardens are easy enough to acquire ; and they are useful to students; but Herbals of all the States and Regions for the learned, with notes, remarks, compared foreign specimens ... are acquired only by many years of travels and re- 
searches, exchanges and purchases. I calculate that mine containing over 10,000 species and 50,000 specimens, has cost me nearly $\$ 2000$ in actual expenses of time, money, travels, paper, boxes, correspondence, transportation, books of reference \&c.

Other Botanists acquire fine Herbals at the risk of their health and life, Botany having also its martyrs ; among whom I will mention I yons, Pursh, Berrich, Baldwin, Conrad, H. H. Eaton, Walton, Ward, Hart, Drummond, Douglass ofec who have fallen victims to their zeal in arduous travels, or from diseases contracted by their labors: although some did perhaps fall victims to alcohol rather than Botany, like Pursh... and others (Schweinitz and Berrich) were rather Victims of Tobacco! both foul poisons and destroyers of human life. Botanists are however generaly sober and healthy, the pursuit of this Science is calculated to improve their habits and health. Baldwin,Waterhouse, and Conrad were victims of Phthisis and improper food; Botany probably lengthened their lives, as it has mine after finding out how to overcome this disease by my medical knowledge of our plants.

In voyages by Sea or Steamboats, some Botanists have been wrecked like myself, losing their collections, and not always so happy as to escape even with life like myself in 1815. I have had also some narrow escapes on the Ohio. Lherminier lost all his collections like myself in Carolina.

The rewards for all these dangers and expenses are scanty as yet with us. We have few professorships of Botany, and this useful science is too much neglected in our Schools. 
Botanical works must even be printed at private expense, as have been most of mine (except my medical flora) and the sales do not pay the expences. We often meet besides with envy or detractors, scorn or neglect. We must therefore find our own reward in the self-satisfaction of having done well, and deserved if not obtained due credit, also in the pleasures inherent in collecting, studying and describing the gifts of Flora, besides the grateful kindness of some congenial friends or well wishers.

Nothing is more unkind, and yet how common, than to hear myself assailed with the questions, why do you not give us your new plants? why are they not found by every body?... ! 'This perversity of ideas and feelings, would be best answered by saying in ironical style, why do you not give me your money? and value my rare plants? or why are you lazy or blind? .... I I am tired to repeat -Go to the mountains and glades, every month of the year, go where I found them at the same season and you will find them. Spend $\$ 500$ in the pursuit, if you will not buy my specimensHowever one half of my new plants are already in the hands of Botanists, having sent them or exchanged or sold to 20 of them. Short, Riddell, Hart $\mathcal{f} \cdot \mathrm{c}$ have found again several of $\mathrm{my}$ Western plants, those of Robin will be found in Atakapas and Texas, those of Kin in the peninsula of Florida $\&$ c.

A crowd of rare plants of Michaux, Pursh, Nuttal \&c are unknown to most of our Botanists. Many plants described by European Botanists Linneus, Aiton, Lamark, Decandole, Hooker, Lindley, Wildenow \&c, are equaly rare with mine, and unknown to many of our 
Botanists. They were chicfly found by foreign travellers, collectors or gardeners and sent to Europe. Kalm, Kin, Noisette, Hingston, Drummond, Lyons, Bradbury \&c found many such in their remote explorations, and so have $I$. Whoever therefore neglects my discoveries is either jealous of them, or unable to distinguish plants. But careless Botanists are often blind to disparities and overlook those rare species, I did so myself once and deemed with Muhlenberg that 15 species of our Lactucas were all L. elongata! thus blending and overlooking distinct sp. So they do to this day, and then they say they cant see them!

\section{NORTH AMERICAN NEOPHYTON.}

I shall dedicate the second part of this flora to describe some of my most remarkable New Herbaceous Plants either new Genera or new Species, reserving the new Trees and Shrubs for the New Sylva of the third part. They shall be enumerated at random rather than by monographs, as I shall refer to them in my future Monographs and natural arrangement. I possess specimens of the whole, and they are all figured in my Autikon and Icones rario.um by those numbers here employed.

201. ODOGLOSSA Raf. meaning toothed ligule. A new Genus near to Coreopsis and Vernasolis, but differing by the neutral rays, and male floscules mixt in the disk.

Perianthe double, both octophylous, the internal colored. Phoranthe convex, chaffs setaceous and few. Rays 8 neutral, rudiment of Ovary linear bidentate, tube flat imperforate, 
ligule or lamina elongate venose, end bifid, sides unidentate. Disk with many florets, male and perfect mixt, Ovary obovate hardly bidentate, florets tubulose 5dentate, stamens free at the end, style hardly bifid. In male florets ovary entire, anthers often quite free. Seeds obovate black hardly bidentate. Perennial, habit of Vernasolis, but root not creeping.

202. Odoglossa heterophylla Raf. stem virgate, naked above, pauciflore sulcate smooth, branches very long uniflore, naked polygonal; leaves rugose beneath, radical petiolate cuneate obtuse entire, inferior petiolate pinnatifid, lobes oblong obtuse 3 to 7 , the last larger, medial leaves sessile oblong entire, External perianthe ovatoblong obtuse nervose, the internal elliptic-In Alabama, Georgia and West Tennessee, rare, stem pedal or more, root fibrose, flowers vernal? rays yellow nearly one inch long, perianthe yellowish. I have not yet found any synonym to this curious plant.

203. LAXANON Raf. Name of Dioskorides for a Lapsana, to which Genus it is akin, in family of Glossanthia or Cichoracea, but differs by naked seeds and simple perianthe.

Perianthe simple 5 to 7 parted, without calicule. Ligules 10 to 15 , seeds ovatoblong striate naked, pappus none, phoranthe naked. Habit of Krigia. One type.

204. Laxanon Parviflorum Raf. smooth, stem ramose terete, branches incurved, leaves graminiform linear lanceolate, entire obtuse, upper ones nearly opposite; flowers terminal, pedicels elongate unequal filiform pubescent, 3 to 5 subumbellate, perianthe smooth, sepals ovate acuminate-Sent me from Alabama, pedal diffuse, flowers yellow very small. This is evidently a very distinct plant. 
205, EPA'IITIS Rat. a name of Diostiorides for Eupatorium. A Genus akin to it and Mikania, but without calicule and the florets reduced to the minimum number of 2 or 3.

Perianthe simple 2 or 3 sepals, no calicule, floscules 2 or 3 longer tubular כfid, seeds compressed linear, pappus simple pilose, phoranthe naked. Habit of Mikania and Cacalia.

206. Epatitis obliqua Raf. smooth, stem angular erect, leaves petiolate obliqual cordate or subsagittate, (one side rounded, another sagitate) acute dentate, flowers corymbose fasciculate, peduncles pubescent, bracts linear, sepals of perianthe cuneate oblong obtuse flatsent me from Oregon, pedal and higher, flowers white and small. It is akin to the Cacalia alpina of Sibiria, but the leaves are not properly cordate, nor flowers with 5 florets.

207. ROPALON Raf. name of Teophrastus for a Nymphea, to which it is akin, but lacks the petals.

Calix 6phyle, no petals, anthers many subsessile, stigma with 12 or more rays truncate. Remainder and habit as in Nuphar.

208. Ropalon sagiteatum Raf. Nymphea sagittifolia Wild. Elliot, N. longifolia Mich. \&c-leaves oblong obtuse sagittate, fruit ovate. - In Carolina and Florida in waters, leaves $\mathbf{6}$ to 8 inches, elongate, flower's estival yellow.

209. Lobelia craduomesa Raf. smooth, stem erect angular, with short branches in the middle, leaves all linear acute adpressed entire : flowers racemose adpressed, capsules subinflate equal to pedicels-sent ine from Alabama, 1 or 2 feet high, flowers blue estival size of $\boldsymbol{L}$. inflata, leaves one inch or more, bracts 
subulate oft equal to pedicels, segments of calix lanceolate acute unequal.

210. Lobelia parvifolia, R. smooth, stem procumbent ramose diffuse flexuose, leaves few small, lower spatulate obtuse subentire, medial oblong subserrate, upper linear entire acute, flawers subracemose lax, pedicels longer than leaves, segments of calix linear-A palachian $\mathrm{mts}$. flowers small bluish. Seen alive in gardens spontaneous. Annual.

211. Lobelia paniculata $R$. stem striate uaked above, leaves pubescent obovate spatulate obtuse repand, mostly radical, only 1 or 2 on stem; raceme ramose subpaniculate, flowers scattered lax, bracts subulate equal to pedicels-mts. Alleghany, rare, annual, stem bipedal, flowers white small. Probably a deviated sp. from L. claytoniana, disc. 1818.

212. Lobelia incurva $R$. glaucous pubescent, stem erect branched, leaves linear cuneate obtuse; flowers axillary racemose, pedicels incurved subequal to leaves, segments of calix lanceolate acute-Florida, annual, pedal, flowers small and blue, akin to L. Kalmi and consimilar blended sp.

213. Lobelia falcata $R$. glaucous smooth, stem simple, leaves long linear falcate acute entire, lower subcuneate ; raceme lax leafy, flowers equal to leaves, calix linear acute-found on Lakes Erie and Ontario, very near to the true $\boldsymbol{L}$. Kalmi of Canada, but with longer falcate leaves, flowers larger pale blue, probably a deviation, collected 1825 .

214. Lobelia fistulosa $R$. stem round smooth fistulose slender, leaves scattered remote linear acute revolute adpressed; fi. ra- 
cemose, bracts subulate glandular longer than pedicels, segments of calix linear very long equal to corolla-sent me from Alabama, pedal, flowers blue middle size, corollas elongate, capsules turbinate.

I have several other $\mathbf{N}$. sp. and Var. of this pretty Genus; see my monograph; my L. nivea descr. 1820 will also be there again.

215. Dipsacus cuneifolius Raf. stem angular aculeate, lower leaves petiolate, cuneate obtuse, crenate, upper leaves sessile cuneate or lanceolate acute entire: head spherical, involucre unequal falcate subulate aculeate, chaff spinose not hooked-In some valleys of the Alleghany mts. and in some glades of Kentucky, disc. 1818, pedal, annual, very different from D. sylvestris and fullonum.

216. TROPITOMA Raf. anomalous or peloric Genus, sprung from Desmodium leucanthum! calix urceolate bilabiate, upper lip bidentate, lower tridentate, corolla not papilionaceous, petals 5uneq. patent, one superior larger or vexillum round emarginate, 4 inferior smaller equal oblong obtuse. Stamens 10 monadelphous, filaments free above divaricate subequal, anthers small round. Ovary stipitate oblong compressed, style lateral subulate, stigma simple acute. Pod with 1 or 2 articulations obliqual ovate, one seed oblong compressed in each. Habit of Desmodium. One type, the name means cut keel.

21\%. Tropitoma paradoxa Raf. erect, leaves few, folioles 3 on long petiols ovate rounded acute scarcely pubescent, pale beneath, flowers terminal 1 to 3-Discovered 1821 in the hills of central Kentucky, semipedal, annual, flowers white. Rare. 
218. Mensanthes latifolia R. folioles sulpetiolate ample ovate or obovate entire subacute, scape subequal to leaves with a lanceolate sessile leaf, raceme lax, bracts short ovate obtuse-Found in Origon by WValton with the next : both akin to M. verna of my med. flora. Robust plant, perennial, ultrapedal.

219. Menyantues timentata $R$. folioles sessile small obovate tridentate, scape much longer than leaves and naked, bracts ovate - Origon, pedal, perennial?

220. Chlonan'rues (Chelone) tomentosa Raf. leaves subsessile broad lanceolate acuminate serrate, base entire, tomentose and grey beneath; fl. axillary and terminal fasciculate nodding-In the mts. of Virginia, stem bipedat, leaves 4 to 6 inches long, 1 or 2 broad, fl. white, perennial, rarc. I have modified into Chlomanthes, the absurd name of Chelone that meant turtle! as if a flower was a reptile!

221. Asarum parvifolium R. stemless, leaves twin radical on long petiols, pilose broad reniform emarginate, peduncle erect, flower large tubular smooth tridentate-On the top of $\mathrm{mts}$. in North Carolina, small plant only 2 inches high, leaves half uncial perennial, flower lark purple, as large as in others.

222. Asarun furcatum $R$. caulescent furcate pubescent, leaves twin reniform subacute, peduncle erect, flower campanulate trifid pubescent-Apalachian mts? leaves four times as large as the last, yet flowers equal in size and same color, but deeper divided. Perennial.

223. Asarum medium R. stemless pubescent, leaves opposite on long villose petiols, cordate reniform acute, perluncle short flexunse villose 
calix base villose, end smooth, tripartite, segments lanceolate-From Missouri and upper Lakes, perennial, semipedal, flowers cinereous or fuscate; the $\boldsymbol{A}$. canadense differs from all these by smooth reniform leaves, calix reflexed \&c.

221. Asarum rotundifolium R. caulescent erect villose, leaves 4 opposite rounded cordate, flower terminal subsessile nodding smoothish campanulate trifid.-Brought by Walton from Origon mts. near A. europeum, which differs by 2 broad reniform leaves, fl. peduncled trilobe $\&$ c, perennial, flower dark purple.

225. Hedyotis geniculata R. smooth, stem geniculate 4 gone, leaves fasciculate lanceolate icute, margin scabrous, pale beneath; fl. axill. solitary, segments of calix linear equal, tube of corolla filiform twice longer than calix-Was ioto hills of Kentucky, semipedal, annual, leaves uncial, flowers purple, their limb campanulate 4 fid, apparently a true Hedyotis, although I did not see the ripe fruit; not a Stelmotis the calix being equal.

226. Galeopsis montana R. dwarf glaucous, leaves few remote petiolate ovatoblong acute serrate pilose, flowers terminal only 1 to 3 calix not pungent-Summit of Oquago $\mathrm{mts}$. near Utsiantha Lake in New York, small annual, only 3 to 4 inches high, flowers incarnate, Prcbably a deviation from $G$. tetrahit, but aspect very unlike.

227. Eustacuya vel Leptandra oppositiFolia Raf; leaves opposite sessile ovate acute (not acuminate) serrulate smoothish, equal to internodes, spike simple-mts. Apalaches of Virginia, perennial, sesquipedal, flower's white small. very distinct from the narrow leaved, whorled sp. of this Genus. 
228. MYCTANTHES (mixed flowers) Raf. anomalous or peloric Genus occasionally formed by some Asters and Solidagos-Difference, flowers often concrete or coalescent, with ligules and floscules intermixt, perianthe imbricate unequal foliaceous. I have noticed several types. Is it a diseased state? but the plants were healthy.

225. Myctanthes punicea R. like Aster puniceus, but stem simple, 2-3flore, leaves lanceolate-observed near Philadelphia, flowers terminal purplish.

230. Myctanthes latifolia R. stem simple uniflore, leaves sessile elliptic acuminate subserrate, flower terminal sessile purplishcollected in the Alleghany mts. bipedal.

231. Myctanthes axillaris R. similar to Solidago nemorosa, but flowers axillary and solitary, yellow-mts. Alleghany, pedal.

233. ALISETA (Plantain) Raf. Radiate Genus near to Arnica-Perianthe in double series, each of ten spreading folioles. Phoranthe flat alveolate, chaffs carinate long acute. Floscules tubulose 5fid sterile. Ligules or rays about 20 fertile tridentate narrow. Seeds linear, pappus simple deciduons. Habit of Arnica, scapose, uniflore-But very different Genus by calix, chaffs, sterile florets \&c. It is nearer to the next Genus Peritris in some respects. Single type.

233. Aliseta plantaginea R. radical leaves lanceolate or cuneate entire hirsute acute, scape terete smooth, with a single subulate scale, uniflore. folioles of perianthe ovate lanceolate smooth-Sent me from Florida, prohably biennial, root short with many fibres, leaves 2 or 3 inches long, scape 6 inches, flower large 2 inches, rays yellow, disk fuscate. 
234. PERITRIS (around triple) Raf. Another Genus akin to Arnica distinct by habit and triple perianthe-Perianthe in triple series, outer shorter with few lax folioles, the 2 inner equal and adpressed. Phoranthe flat naked. Rays few tridentate. Seeds oblong compressed pubescent, pappus simple. Habit of Jacobea, caulescent corymbose.-Perianthe nearly like Aliseta with the addition of a calicule, but chaffs lacking and habit unlike.

235. Peritris ovatifolia $R$. puberulent, stem erect subangular lower leaves petiolate ovate serrate acute, petiols winged, upper leaves sessile ovate lanceol. serrulate or entire; corymb ramose racemose, peduncles erect, bracts subulate, folioles of perianthe lanceolate-Florida and Alabama, pedal, perennial, fl. yellow, perianthe smooth, calicule or outer pubescent.

236. Arnica brevicaulis Raf. smooth, scapose, leaves obovate and cuneate, obtuse, unequally crenate and laciniate, scape shorter than leaves and with flowers umbellate, bracts lanceol. wooly in the axiles. peduncles unequal, some very long, striate uniffore with 1 or 2 subulate bracteoles, perianthe lanceolate, wooly at the base.-Sent me from Alabama, stem only 4 inches, leaves 6 , flowers large yellow, few rays, pappus white, seeds oblong angular smooth. This appears a real Arnica near $\boldsymbol{A}$. nudicaulis. the perianthe being simple.

237. Bellis parviflora Raf. stem branched diffuse, leaves sessile oblong acute entire scabrose, peduncles terminal long naked, rays linear-In Kentucky on rocks, rare, annual, semipedal, leaves small, flowers white estival very small half size of $B$. integrifolia.

238. Bellis nutans Raf. stem simple uni- 
flore striate, leaves remote sessile cuneate acute entire pilose ciliate, flower nodding-In the glades of West Kientucky, annual, flowers vernal white same size as $\boldsymbol{R}$. integrifolia, which grows by millions in those glades, where I found them all in 1823. These plants really belong to the G. Bellis and not Eclipta as deemed by Sprengel, nor Brachycome of Cassini, genus based on Bellis aculeatre and cilia$r$ is of Australia, to which Lessing has wrongly united B. integrifolia. In order to contrast my species I must add this and also the Texan species.

239. Belis integrifolit Mx. and Amer. Authors. Eclipta do Spr. Brachycome xanthocomoides Lessing-smoothish, stem branched multiflore erect, branches 1 or 2 flore, lower leaves petiolate spatulate obtuse, upper sessile cuneate acute not ciliate, flowers erect rays oblong-All over the Western States, Ohio, Indiana, Illinois, Missouri, Kentucky, Tennessee foc in glades, vernal white flowers, stem 6 to 15 inches high erect, 3 to 12 flowers, not seen by Pursh, nor Nuttal till he went to Arkanzas, a proof that a very common plant may escape notice if you do not visit the localities in due season. Several varieties 1 pumila 3 inches high, 3 flowers only, 2 elata, sesquipedal, multifore, 3 crernea flowers of a blushing color. \&oc, all annuals.

240. Bellis ciliata Raf. B. integrif. Hooker bot. mag. 3455. Pubescent, stem crect mulflore, lower leaves petiolate spatulate obtuse base ciliate, upper sessile oblong acute ciliate, peduncles naked erect, rays cuncate-annual, found by Drummond in Texas, and probably cxtending to Louisiana and Arkanzas, blended 
with the last by Hooker, his description including both, his figure appears the texan plant which has been sent me by 'Torrey, and I describe original specimens of Drummond; it has also a var. trifiora, with leaves all acutish and only 3 flowers. 'The folioles of the perianthe are lanceolate acuminate in all the sp. not linear as Hooker says, the seeds are obovate pubescent.

241. Parthenium angustifolium Raf. stem virgate angulate smooth, above rough, lower leaves petiolate narrow cuneate or oblong crenate obtuse rough, upper leaves sessile ovatoblong ; flowers corymbose globose, fol. of perianthe ovate rounded acute-In the barrens or glades of West Kentucky, 2 or 3 feet high, petiols long, leaves 6 to 8 inches long, 1 or 2 broad. Very distinct from the 3 next sp. all are estival and perennial.

242. Parthenium pumilum Raf. stem dwarf, striate, smooth, lower leaves petiolate obovate crenate obtuse rough, upper cuneate sessile nearly entire acute; corymb glomerate, fol. of perianthe ovate acute rough-In the $\mathrm{mts}$. Warioto or Cumberland, stem smooth striate semipedal, leaves rough small, flowers white.

213. Parthenium sinuatum Raf. stem sulcate elate smooth, leaves nearly glabrous rugose, radical ample petiolate ovate deltoid sinuate laciniate, obtuse, stem leaves sessile amplexicaule ovate repand sinuolate; corymb sessile glomerate, fol. of perianthe roundedMts, of Virginia, probably blended with the next by Authors, but by no means integrifolium! large leaves, lower often 10 inches long decurrent on the petiols, flowers few globular whitish. Stem commonly 3 feet high. 
244. Partheniom amplectens Raf. P. integrifolium L. and Authors? Stem angular rough elate, leaves all rough ovate oblong amplexicaule serrate acute, corymb lax, fol. of perianthe ovate rounded acute carinate.-Glades of Kentucky, 2 to 4 feet high, leaves 3 io 6 inches long, lower hardly attenuate at base, flowers whitish. $\boldsymbol{P}$. integrif. is a name illusive and to be abolished, it was given by Lin. in contrast with $\boldsymbol{P}$. hysterophorus with multifid leaves, that now is a peculiar Genus. 'The Linnean sp. figured in Dillen and Plukenet had leaves ovate crenate hirsute, lower with earinate petiols, upper sessile, flowers snowy white, tip of perianthe black, and may still be different from all mine, found in Virginia, might be called $\boldsymbol{P}$. dillenianum? -The sp. of Elliot is still somewhat different, it may be called $\boldsymbol{P}$. elliotanum? stem 1 or 2 feet striate roughish, leaves rough toothed ovate lanceolate; lower sessile, upper amplexicaule-as near to $P$. angustifolium as to this. See 280 .

245. Urtica verna Raf. nearly smooth, stem simple slender, leaves remote opposite petiolate acuminate laciniate serrate, the lower cordate, medial ovate. upper lanceolate; male spikes inferior shorter than petiols, female fl. glomerate above, glomerules nodding geminate peduncled.-Kentucky and other Western States, in woods, flowers vernal in may, pedal, leaves small, a true Urtica with male fi. 4 parted 4 andre. Var. gracilis very slender virgate, leaves small none cordate.

246. Oxalis rupestris Raf. stem erect angular rufous pilose, leaves glaucous smooth, folioles obcordate, sinus obtuse, peduncles longer than leaves 3-5flore, sepals lanceolate, pe- 
tals retuse obovate.-On the cliffs of the River Kentucky, 8 to 12 inches high, flowers large pale yellow, estival.

247. Oxalis cespitosa Raf. creeping, cespitose pilose, stems assurgent, petiols filiform, folioles obcordate ciliate, sinus acute, peduncles filiform longer than ieaves 2-3flore, pedicels equal to flowers, bracts linear, petals obovate double of calix, capsules pilose-Glades of West Kentucky and West Tennessee, abundant, vernal, found in May and June 1823: near to $O$. lyoni, 3 to 5 inches, forming small tufts, leaves small, flowers large one inch broad pale or lemon color.

248. Capsella acutifolia Raf. stem simple smooth, radical leaves short pinnatifid, pinnules ovatoblong dentate acute, stem leaves sagittate lanceolate very acute subentire amplexicaule, raceme naked, silicules short deltoid hardly emarginate, pedicels long filiform spreading.In the Alleghany mts. pedal annual with white flowers and estival, as all the sp. of this Genus of Mench, Ventenat and Decandole, who admits of only one sp. C. bursa, with 4 varieties minor, integrif. coronopif. apetala; but I have 8 or $10 \mathrm{sp}$. in my herbal, whereof 6 from $\mathbf{N}$. America, and many more exist perhaps in Africa and Asia.

249. Capsella integrifolia Raf. Var. do Dec? stem slender simple radical leaves cuneate acute, attenuate in petiol at the base, quite entire, stem leaves oblong acute sessile not sagittate entire, silicules deltoid emarginateHills of Pennsylv. and Kentucky, semipedal, certainly as distinct a sp. as can be! leaves not even toothed as in the next, nor sagittate above. 
250. Capsella nentata Raf. dwarfish stem simple nearly naked radical leaves petiolate cuneate or obovate toothed, stem leaves 1 or 2 sagittate linear, raceme lax elongate, silicules deltoid truncate shorter than pedicels.-In mts. Alleghanies, 3 or 4 inches high only, akin to last, but leaves toothed and upper sagittate. Is it the Var. minor of some botanists?

251. Capsella bifida Raf. several stems, radical leaves oblong toothed, stem leaves sagittate entire glaucous roughish, racemes elongate, silicules oblong base acute end bifid, pedicels subequal.-In Pennsylvania glades, pedal, annual, very distinct by silicules longer than broad and almost bifid, no runcinate leaves \&c.

252. Capsella furcata Raf. all leaves spatulate oblong obtuse entire or hardly toothed, silicules broad furcate, pedicels equal-In Canada and Europe, semipedal, distinct by the peculiar silicules broadly obdeltoid, wider than long, and uniform leaves, quite obtuse.

253. Capsella amblodes Raf. all leaves pinnatifid, acute, pinnules often angular, silicules, shorter than pedicels, oblong cuneate obtuse, emarginate-sent me from Europe as a variety of C. bursa, probably also in N. America, annual dwarfish 3 to 4 inches high only, qnite peculiar silicules, and uniform leaves.

254. Capsella bursa Raf. non Auet. Thlaspi bursa pastoris $\mathbf{L}$. and most of our botanists. Radical leaves pinnatifid runcinate, pinnules entire,stem leaves oblong sagittate dentate, silicules shorter than pedicels deltoid triangular base and corners acute, hardly emarginate-In Europe, introduced in fields and the roads in N, America, pedal and sesquipe- 
dal, nearest to $C$. acutifolia, chief difference in pinnules entire less acute broader, silicales quite triangular with acute angles.-It is probable that these plants are deviations sprung from each other, but some are really native of wild localities and not introduced : to deem them mere varieties would be preposterous, since they differ as widely in leaves and fruits as any acknowledged species of Sinapis or Iepidium, which ought on such felse principles be made but single species. I have not yet met in America the C. coronopifolia of Europe having leaves with narrow remote segments. The monstruous deviation called apetala by Opiz and Decandole, is evidently an incipient New Genus formed in Europe, not even of this family, having no petals, 10 stamens, instead of 4 petals and 6 stamens ! I call it OpIzLA BURSOIDES Raf.

255. Calystegia riparia Raf. sepium of Amer. bot. not L. nor Europe. Procumbent, twining, leaves cordate oblong, lobes rounded seldom acute, peduncles uniflore terete very long, calicule longer than calix ovate concave obtuse-annual, on the margins of rivers, streams and marshes in New Jersey and New York, flowers estival white incarnate. Mistaken by our botanists for the Convolvulus sepium of Europe, Calystegia sepium of R. Brown and Pursh; a smaller plant not climbing, leaves and flowers smaller.

255. Brunella microphylila Raf. stem pilose geniculate dwarf, leaves very small smooth subentire obtuse, lower ovate on long petiols, upper oblong subsessile, heads subsessile globose or ovate, bracts scariose reniform venose ciliate acuminate-summits of $\mathrm{mts}$. in Allegha- 
nies and Kiskanom mts. only 2 or 3 inches high, leaves not half an inch, flowers small purple vernal. Annual like all the species?

257. Bruneli.a sessilifolia Raf. stem terete branched rough above, branches brachiate, leaves sessile narrow lanceolate acute entire smooth, margin rough, heads oblong, bracts cordate acuminate ciliate, calix ciliate colorate -Florida sesquipedal, leaves 2 or 3 inches long, heads elongate 3 inches long, calix red, flowers purple, handsome sp. near Br. intermedia of Europe, but leaves entire and smooth.

258. Brunella petiolaris Raf. smooth, stem simple subterete, leaves on long petiols, lower obovate or cuneate entire obtuse, upper lanceolate acute subdentate, heads ovatoblong short, bracts ciliate reticulate cuspidate cordate, calix smooth cuspidate-In Kentucky pedal, radical leaves smaller, upper leaves long narrow triuncial, flowers estival as in nearly all.

259. Brunella hirsuta Raf. Hirsute rough, stem simple 4gone, leaves remote petiolate crenate, lower ovate obtuse, upper elliptic oblong subacute, heads short truncate, bracts hirsute ciliate acuminate, calix ciliate acute-Illinois and Missouri, pedal, flowers bluish purple.

260. Brunella cinerea Raf. creeping villose cinereous, radical leaves petiolate round and ovate, obtuse crenate, upper leaves oblong or linear nearly entire margin involute, heads oblong sessile, bracts reniform acum. ciliate, calix hirsute at the base-Florida, Alabama, Wasioto mts. and hills of Kentucky, biennial. vernal very distinct, although akin to last and next. Stem semipedal, leaves small uncial, heads 2 inches long, calix as in most sp. upper lip 3dentate, lower bifid ciliate. 
261. Brunella heterophyla Raf, smooth erect. leaves petiolate subcrenate repand, radical ovate rounded obtuse, on stem ovate or oblong, heads sessile ovate short-on mts. Alleghany, akin to the last, but annual estival erect smooth, green not ash color.

262. Brunella cordata Raf. stem erect simple red, pilose above, petiols ciliate, leaves smooth ovate acute subentire pale beneath, lower cordate serrate, heads oblong sessile with 2 oblong leaves, bracts reniform reticulate ciliate-Alleghany mts. pedal, fine species, calix red, corol purplish blue, estival.

263. Brunella reticulata Raf. stem erect smooth, leaves petiolate elongate ovatoblong entire, acute at both ends, heads on a hairy peduncle, oval short, bracts reticulate acuminate ciliate, calix smooth-in Ohio, Kentucky $\& \cdot c$, fine species, sesquipedal, leaves 3 or 4 inches long, spike short hardly over one inch, calix with lips 3dentate and bifid as usual, but quite smooth. Akin to the last but differs by entire leaves and short heads not sessile.

264. Bronella rosea Raf. dwarf, stem decumbent hairy above, leaves petiolate smooth oblong and lanceolate acute subentire, lower crenate, heads oval subsessile, bracts scariose reticulate cordate ciliate acuminate-in the Turkey mts. of Alleghanies, only 2 to 4 inches high, stem 4gone, angles with a few hairs, leaves uncial, heads uncial or less, flowers estival of a fine rose color different from all the others. Very distinct sp. only slightly akin to $\mathrm{Br}$. microphyla in habit, but nothing else, calix ciliate. A variety has shorter heads and more crenate leaves, stem nearly erect. Var. breviflora. 
265. Brunella obtusifolia Raf. stem erect hairy above, leaves petiolate ovate obtuse entire or subrepand, heads oblong subsessile bracts scariose colored ciliate reniform acuminate; calix colorate ciliate-in Pennsylvania \&oc, more similar to $\boldsymbol{B r}$. vulgaris of Europe than any other, pedal, estival, perennial, bracts and flowers red. These $10 \mathrm{sp}$. of Brunella (miscalled Prunella by error of the press) are usually blended (when seen by our botanists) with the Br. pennsylvanica of Muhlenberg: to unite such diversities is preposterous. The real pennsylvanica which is the vulgaris of others differs from this my obtusifolia by creeping roots, ascending stems, leaves ovatoblong acute toothed at the base, \&c. I have even yet some other American and European blended sp. in my herbal, or at least striking varieties, some with white flowers.

266. Buchnera missurica Raf. rough pubescent, stem adscendent base hirsute, leaves opposite and alternate crowded imbricate lanceolate subentire, radical ovate, upper ones small subulate squamulose remote, flowers in short spike, alternate at base, bracts subulate short-Glades of Missouri and Illinois, pedal, perennial, calix ureeolate, tube of corolla slender strait.

267. Buchnera angustifolia Raf. stem virgate terete nearly smooth, naked above, leaves remote linear obtuse entire roughened by white hairs, flowers scattered sessile in the spike-in Alabama, sesquipedal, capsules globose in calix ovate 5lobed. These two sp. are quite distinct from B. americana, see 298.

268. Cupirea aldida Raf. stem simple humble pauciflore, leaves petiolate ovate lanceolate 
hardly viscose pubescent entire obtuse, flowers axillary subsessile, calix hispid striate, petals white cuneate small-in the Alleghanies of Pennsylvania, only found once in 1833, north of Carlile, annual, semipedal,quite distinct from C. viscosissima having many purple flowers, stem much branched and clammy, leaves narrower lanceolate of $c$.

269. Comandra obovata Raf. stem ramose angular striate, leaves oboval subobtuse, umbellules 3-5flowered, pedicels equal to flowers, bracts obovate equal to pedicels-mts. Alleghanies pedal. The Thesium umbellatum of $\mathrm{L}$. has been well described as a N. G. Comandra by Nuttal, but he neglected the species thereof, and so have done all our botanists, there are now 7 or 8 sp. of this G. and I will distinguish 5 sp. of it, all blended by our careless Authors. All have white estival flowers.

270. Comandra elliptica Raf. stem angular hardly branched, leaves broad oblong elliptic acute, umbellules sub 5flowered, pedicels shorter, bracts lanceolate equal to pedicelscommon, pedal, estival, probably the C. $\mathbf{\imath m}$ bellulata of Nuttal and most of our Botanists.

271. Comandra obtusifolia Raf. stem angular branched above, leaves imbricate narrow oblong obtuse, umbellules 3-5fl. pedicels very short or wanting, bracts subulate-Ohio to lllinois, semipedal.

272. Comandra media Raf. stem terete striate ramose, leaves broad oblong acute, umbellules 1-3flore, pedicels equal, no bracts-in New Jersey and Virginia, pedal.

273. Comandra cuneifolia Raf. stem slender subangular, leaves lax cuneate nearly acute umbellules 3-5flore, pedicels very short, bracts 
ovate short-West Kentucky, discovered 1823, pedal. I possess all these sp. which are such wide deviations as to be $\mathrm{sp}$. rather than varieties.

274. Hydrastis trifolia Raf. stem flexuose three leaved, Iflore, leaves ample, lower petiolate, 2 upper sessile, reniform 3-5lobed, unequally serrate ciliolate, lobes ovate acute, glaucous beneath, flower sessile at the third leafWest Kentucky, over one foot high, lower leaf 6 inches wide. This Genus was thought monotype, if this is not a N. sp. it is a very singular deviation of form, as $\boldsymbol{H}$. canadensis has always 2 leaves not ciliate \&c. Flower white early vernal.

275. Geranium lenticulum Raf. Pilose, stem erect slender sulcate branched, leaves opposite and alternate on long petiols 5-7parted segments linear lanceolate entire acute, peduncles biffore shorter than petiols, calix sepals lanceolate nervose aristate, seeds lenticular pubescent-West Tennessee and Kentucky, pedal, flowers small, petals purple, estival, annual, in glades.

276. Geranium pedatum Raf. smooth, stem diffuse filiform striate, leaves alternate on long petiols small pedate 7-9fide, segments linear, medial cuneate trifid, peduncles very long, filiform 1-2flore, calix sepals ovate enerve acuminate, seeds oblong smooth.-Glades and Prairies of West Kentucky and Illinois, semipedal, annual, flowers small purple vernal.

27\%. Isantuus pumilus Raf. smooth, stem dwarf hardly ramose, leaves subpetiolate lanceolate acute hardly trinerve, pedicels uniflore short, equal to calix, shorter than leaves, calix ciliate-Glades of West Kentucky and Tenn- 
essee, annual estival, only 3 to 4 inches highleaves not ciliate, but the calix instead.

278. Isanthus pubescens Raf. quite pubescent, stem branched, leaves sessile trinerve lanceolate acute, peduncles biflore curved subequal to leaves longer than calix-Mts. Wasioto or Cumberland of East Kentucky, annual, pedal. This is nearer to $\boldsymbol{I}$. ceruleus of Mx. my Is. ciliatus which has however leaves orate lanceolate ciliate, short peduncles and is nearly viscid.

279. Isanthus multiflorus Raf. smooth, very branched, leaves sessile linear lanceolate uninerve, peduncles multiflore, pedicels shorter than calix-with the last in the Wasioto hills, semipedal, annual. Thus this monotype American Genus is now increased by me to 4 species ; they are all estival and commonly grow in Limestone soils, I have perhaps another doubtful from Texas, with obovate leaves.

280. Parthenium hispidum Raf. stem flexuose sulcate hispid, hairs white, lower leaves obovate base acute, the lowest on a long hispid petiol, upper leaves sessile oblong and ovate, base truncate, all acute with large unequal teeth ciliolate, slightly hispid on both sides, flowers corymbose glomerate sessile tomentose pale fulvous-another sp. of this American Genus, from the Glades of Arkanzas and Texas humble, hardly over a foot high, with stiff white hairs, only one radical petiolate leaf, few leaves all different in size and shape, flowers fulvous white, perianthe with ovate obtuse sepals.

281. Triosteum connatum Raf. perfoliatum and majus of some bot-stem sulcate pubescent, leaves connate ovate rhomboidal acuminate undulate, rough above, tomentose beneath 
axils 1 or 2flore, flowers sessile calix unequal linear pubescent-in the Alleghany mts. bipedal, corol rufous red subequal 5lobed, berries purple. Of this Genus our botanists admit only two species perfoliatum and angustifolium, but the first also called majus by some contains many blended species, and it is hard to say which is meant by each, as few give original descriptions: this is the sp. of Elliot. I shall increase this Genus to $8 \mathrm{sp}$. quite distinct, they are all perennial estival plants, with stem simple and axillary flowers, commonly found in limestone or sandy soils. The roots of all are medical and febrifuge, see my medical ffora.

282. Triosteum molle Raf. entirely villose soft, leaves subconnate broadly oblong acuminate undulate repand, villose above, tomentose beneath, axils triflore, flowers subpedunculate -Received from Missouri, bipedal.

283. Triosteum villosum Raf. stem striated villose, leaves sessile ovate acute base attenuate, smooth above, villose beneath, axils multiflore upper sterile, flowers sessile, calix lanceolate-in the sandy soils from Maryland to New Jersey, bipedal, or tripedal corol short dark purple, berries purple.

284. Triosteum pumilum Raf. stem dwarfish sulcate villose, leaves sessile oblong elliptic acute, villose beneath, axils uniflore, flowers sessile calix villose long linear-on the Apalachian mts. of Virginia, only one foot high or even less, quite distinct from $\mathrm{Tr}$. angustifolium, probably the minus of some botanists.

285. Triostedm angustifolium L. Elliot \&c, stem hairy, leaves subconnate lanceolate spatulate acuminate slightly scabrous, axils 
uniflore, flowers peduncled-in Kentueky, Tennessee and Apalachian mts. of Carolina, 2 or 3 feet high, corol yellow, berries red. I collccted this in the glades of West Kentucky,

286. Triosteum hispidum Raf. stem flexuose striate hispid, leaves sessile ovate spatulate acuminate smooth ciliolate, axils uniflore, flowers sessile, ovary hispid, calix smooth linear lanceolate-in the glades of West Kentucky with the last, but quite distinct by broader smooth leaves quite sessile, corol orange color.

287. Triosteum hevigatum Raf. entirely smooth, stem fistular, leaves sessile ovate rhomboidal acute at both ends, axils 2-3flore, flowers sessile, berries safron color-on the Apalachian mts. of Georgia and Alabama, seen alive in gardens, quite distinct by perfect smoothness of stem and leaves, flowers small orange color, berries also or nearly safron color.

288. 'Triosteum obovatum Raf, stem fistular tomentose, leaves sessile obovate broad ample acuminate tomentose beneath, axils 2-3flore fl. sessile, berries red-from New York to Illinois, the most common sp. in the Western States, often mistaken for the Tr. majus, quite different from my connatum by sessile obovate leaves, larger than in any other, stem 3 to 4 feet high.

289. Phryma media Raf. subpubescent, leaves petiolate equally serrate, lower cordate, upper ovate acute, last pair sessile, bracts subulate shorter than calix-in Kentucky, annual and estival like all the species. Our botanists admit of only one, but it offers so many deviations that I have collected 3 incipient sp. which I add with the real type of Plir. leptostachya. 
290. Phry leaves subsessile ovate or elliptic, subcordate acuminate ciliate unequally crenate, last pair entire, bracts subulate equal to calix-Alleghany mts. pedal, flowers purplish.

291. Phrya parvifolia Raf. smooth, leaves all petiolate ovate oblong equally serrate bracts shorter than calix-Alleghany mts. pedal, leaves small uncial, flowers white.

292. Phryma leptostachya L. foc. smooth, leaves difforme lower petiolate ovate base acute deeply serrate, upper sessile ovate often entire, bracts equal to calix - the most common kind, from New York to Carolina, 1 or 2 feet high. If all the above are mere varieties of this, they afford a fine illustration of incipient species forming under our eyes in our woods.

293. THECANISIA Raf. a N. G. of Spirea tribe, near to Filipendula-cal, 5fid. persistent reflexed, petals 5, stamens few 12 to 15 , pistils 3-5 stipitate with a style, stigma capitate. Fruit 1 to 5 thecas unequal stipitate oblong 13seeded. Herbaceous perennial plants with lobed or palmate leaves subpinnate, stipulate, flowers paniculate.-The essential character besides habit is found in the stipitate unequal pistils and fruits, the types are Spirea lobata and discolor, but others probably belong here, and $I$ add two. The name means unequal thecas.

294. Thecanisia lobata Raf. Spir. do Authors leaves subpinnate smooth, folioles 3lobed, the last Flobed, lobes lanceolate doubly serrate, panicle cymose compound-from Carolina to Alabama in hills, large plant $\mathbf{3}$ to $\mathbf{4}$ feet high, flowers rose colored.

295. Thecanisia ponpurea Raf. stem stri- 
ate, leaves smooth, pinnate palmate triparted, medial lobe large petiolate 3-5lobed, lobes oblong acute, laciniate dentate, stipules oblong serrate, panicle lax naked-in 'Tennessee and West Kentucky, 2 or 3 feet high, flowers purple, probably blended with the last, chiefly distinct by lobes and panicle.

296. Thec. angustifolia Raf. stem striate flexuose, leaves palmate rugose, reticulate beneath, 5 to 7lobes lanceolate acuminate unequally serrate, stipules foliose laciniate, panicle lax.-Mts. of North Carolina and Georgia, very distinct by narrow lobes, flowers purplish.

297. Thec. discolor Raf. Spirea do P.\&c, stem angular sulcate, leaves subtrifoliate, lobes ovate acuminate unequally serrate, white tomentose beneath, middle foliole cordate trifid, some small pinnules interjected ovate sessile, stipules small, panicle interrupted coarctateApalachian mts. a beautiful sp. 1 or 2 feet high, flowers white.

298. Buchnera levicaulis Raf. stem virgate fistular quite smooth, above naked angular, leaves remote narrow lanceolate entire acute rough, spike short flowers alternate-Florida, a very distinct sp. stem 2 feet high very slender and smooth, leaves small uncial opposite sessile, spike uncial, flowers few small sessile alternate, bracts ovate acute half length of corolla. This with 266 and 267, increase to 4 our N. Amer. sp. they have probably all been blended in $\boldsymbol{B}$. americana which is quite distinct by roughness and opposite flowers \&c. They are all estival, growing in glades out of woods, and dry black in herbarium.

299. ECLIPTA of L. a good Monograph of this Genus is much wanted, I shall attempt 
it for our N. Am. sp increased to 6, while our botanists know only 2 or 3 , and blend half a dozen with $\boldsymbol{E}$. erecta of South America, quite different from ours. These plants are estival or autumnal, all annual, with a similar habit of opposite sessile leaves, flowers often axillary and geminate. All have the perianthe biserial, many narrow rays and the seeds naked; with a bristly phoranthe, whereby they differ from Bellis, and the habit is totally unlike; but some sp. are stated to have besides a small bristly pappus, such are E. procumbens of Elliot and my $\boldsymbol{E}$. ciliata fl. Iud. which therefore approximate to Verbesina and Galinsoga, and are perhaps two peculiar Genera Paleista and $\mathbf{C a}$ cotanis. As to $E$. brachypoda Mx. which was Amellus carolinianus Walter, with pentandrous florets, no one else has seen it since, not even Elliot, and it will perhaps be found also a peculiar Genus or a Paleista.

300. Echipta longifolia Raf. stem erect slender weak trichotome nearly smooth, leaves sessile long lanceolate, acute at both ends, uninerve remotely serrate, nearly smooth, flowers erect axillary and terminal 2 or 3 together, peduncles unequal hispid, sepals of perianthe unequal oval or lanceolate acute ciliolate-a very distinct sp. from $\boldsymbol{E}$. erecta mistaken for it by nearly all the botanists, growing from Florida to New Jersey near streams, lately found by me near Philadelphia at the mouth of the Schuylkill. Stem 2 or $\mathbf{3}$ feet high, leaves remote 4 to 8 inches long, hardly one broad, flowers whitish autumnal, seeds brown 4 gone, obovate. I add for contrast the others $\boldsymbol{E}$. erecta!

301. Eclipta dubia Raf. E. erecta Pursh, 
Elliot \&c erect dichotome strigose, leaves sessile lanceolate base attenuate, remote serrate, triplinerve, flowers geminate, peduncles long, sepals of perianthe ovate acuminate-Virginia to Florida in gravelly soils, flowers estival: thus very different from last, but I have not seen it, it may have been badly described, therefore is dubious.

302. Echipta flexuosa Raf. L. erecta L. fo. Stem erect nearly simple hirsute subflexuose, leaves sessile lanceolate undulate unequally serrate triplinerve, flowers 2 or 3 , peduncles wooly, sepals of perianthe ovate-in Guyana and South America, biennial 2 or 3 feet high, thus totally unlike the two above.

303. Echipta tinctoria Raf. $\boldsymbol{E}$. erecta Wild. Pers. \&oc. stem erect strigose, leaves sessile oblong lanceolate remote serrate-in Asia and Egypt, used to die black, certainly different again from all the American sp. but requiring a better description.

304. Echipta simplex Raf. stem erect simple strigose above, lower leaves ovatoblong obtuse petiolate, upper oblong or lanceolate sessile acute uninerve, subentire, hardly strigose nearly smooth, flowers solitary axillary or terminal, sepals of perianthe ovatoblong acutesent me from Alabama and Tennessee as $\boldsymbol{E}$. procumbens although quite erect. A small sp semipedal, with few leaves and flowers, leaves 1 or 2 inches long.

305. Eclipta sulcata Raf. stem erect trichotome sulcate nearly smooth, leaves narrow lanceolate sessile acute, subserrate in the middle, nearly smooth, peduncles geminate unequal hispid, sepals of perianthe ovate lanceolate acute-Louisiana, sent me by Riddell as 
the $\boldsymbol{E}$. procumbens ? nearer my longifolia, but leaves only 2 or 3 inches long, stem sulcate, sepals broader but not acuminate as in $\mathbf{E}$. dubia.

306. Eclipta dichotoma Raf. E. erecta Nuttal in Collins herb. stem erect dichotome smooth, leaves small sessile lanceolate and oblong acute entire or subserrulate substrigose, flowers 2 or 3 axillary and terminal, peduncles short subhispid, sepals ovate acute. Arkanzas, found by Nuttal, mistaken also for $\boldsymbol{E}$. erecta, quite distinct, stem slender 3 or 4 feet high, leaves remote uncial, sometimes small leaves on the lower peduncles, imitating short branches, flowers small smooth, seeds brown oblong sub 4gone.

30\%. Eclipta pumila Raf. dwarf hispid rough, stem simple erect 1-3flore, leaves sessile lanceolate acute or obtuse subentire, flowers axillary solitary, peduncle short, sepals oblong -Mts. Cumberland of East Kentucky, 1 or $\mathbf{2}$ inches high only, perhaps a deviation of $\mathbf{E}$. simplex.

308. Eclipta nutans Raf. stem decumbent or assurgent flexuose trichotome rough above, leaves sessile strigose, oblong lanceolate or cuneate hardly serrate acute uninerve, on the branches linear lanceol. entire, flowers axillary and terminal geminate nodding, peduncles very short, sepals ovate lanceolate acute-in Kentucky also the banks of the Ohio and Potowmak, pedal or less, leaves small uncial, flowers very small. This has probably been the $\boldsymbol{E}$. procumbens of $\mathrm{Mx}$ and many botanists, but not of Elliot and others. It has some varieties 1 pauciflora, assurgent nearly simple few flowers, 2 diffusa leaves often cuneate below, most- 
ly oblong. This is the only prostrate sp. I have seen, and it is often assurgent.

309. PALEISTA Raf. Perianthe uniserial 8-10sepals unequal serrate fimbriate, rays numerous 24-30 short linear 2dentate, floscules 4fid 4androus, phoranthe with fringed bristles, seeds 4 gone tuberculate, crown with a thick margin and a pencil of short bristles. Procumbent, radicant branched, leaves opposite, flowers commonly geminate.-Thus this $\mathrm{G}$. differs from Eclipta in perianthe, chaff and seeds.

310. Paleista procumbens Raf. Eclipta do Elliot not others. Procumbent strigose trichotome, leaves sessile triplinerve long lanceolate remotely serrate, peduncles elongate, 1 or 2 , sepals of perianthe lanceolate acute serrate fimbriate-in Carolina and Florida in damp soils, flowers small white estival and autumnal: certainly quite distinct from my Eclipta nutans, nearer to $\boldsymbol{E}$. longifolia in some things. I add to this the doubtful $\boldsymbol{E}$. brachypoda not seen by me, but to contrast them.

311. Paleista? braciypoda Raf. Ecl. do. Mx \&c Amellus Carolin. Walt. prostrate divaricate, leaves lanceolate nearly entire, peduncles 1-2 very short, sepals oval lanceol. floscules 5andre-in Carolina \&c perhaps a peculiar G. or subgenus to be called Brachypoda prostrata!

312. CACO'TANIS Raf. Perianthe conical imbricate, with many rows of sepals, many rays, chaff bristly, seeds compressed notched crowned by a few small bristles. Leaves alternate, flowers terminal.-I united this plant to Eclipta in 1817 by a mistake, the habit is totally unlike our Feliptas. It differs fiom all 
the genera blended in Verbesina by many rays and bristly seeds, from Galinsoga by the pappus not paleaceous \&c. The generic name means bad herb.

313. Cacotanis ciliata Raf. Eclipta do fl. lud 214. Stem erect terete smooth, leaves alterne sessile remote linear smooth ciliate thick -in West Louisiana, 2 or 3 feet high, flowers few terminal one inch broad, rays white, disk yellow. Autumnal. Smell like Cicuta, taste acrid, deleterious.

314. CLIPTERIA Raf. Perianthe nearly uniserial 8-10 unequal sepals, phoranthe convex bristly, rays none, florets crowded, seeds naked. Dichotome, leaves alternate, flowers terminal geminate - very distinct Genus known at first sight from Eclipta by alterne leaves, and flosculose flowers. The name means deficient around.

315. Chipteria dichotoma Raf. stem erect smooth dichotome, branches biflore, leaves sessile oval oblong acute nearly entire uninerve smooth, peduncles geminate elongate, sepals of perianthe ovate long acuminate-Sent me anonymously from West Tennessee and the Chacta Country, stem bipedal, leaves and peduncles uncial, flowers green and small. I had first called it Eclipta levigata, but it appears a peculiar genus by habit, even if there should be short rays, my specimens have none, but the dry Ecliptas seldom show them. Could this be the Galinsoga parviflora of Mg. Catal. mentioned by no one else? it is certainly not the peruvian plant.

316. DIPLOSTELMA Raf. Radiate, perianthe oblong turbinate imbricate sepals unequal, margin scariose external short. Rays 
few oboval, floscules few tubular. phoranthe naked, seeds oblong smooth crowned by a double pappus, external short paleaceous scariose, internal bristly longer. Annual ramose, leaves alternate, flowers terminal-a pretty little Genus near Bellis in habit, quite distinct by few rays and seeds. I find it under the name of Acticarnopus (in Collins hemb) Genus unknown to me and the name cant apply, the seeds and not the fruit being stellate. My name means a double crown. I have $3 \mathrm{sp}$. of it.

317. Diplostelia pumla Raf. divarf erect ramose strigose, branches angular uniflore, leaves sessile entire, lower cuneate or spatulate obtuse, lower linear cuneate acute, sepals of perianthe lanceolate acute rays about 5.Texas and Arkanzas a small annual plant 2 to 4 inches high, with many slender branches and leaves, flowers estival, rays apparently white obtuse subentire, floscules 5 to 8 only, seeds and pappus fulvous. Found by Nuttal in Arkanzas.

318. Diplostelma rabians Raf. strigose erect, branches filiform pauciflore, lower leaves petiolate spatulate obtuse entire, upper few linear acute, sepals lanceolate cuspidate rays obt. 8-collected by Drummond in Texas, 6 to 8 inches high, flowers smooth, white, rays cuneate 8 to 10 , floscules fewer 4 to $\%$.

319. Diplostelia filiformis Raf. erect, branches filiform rough, much divided, branchlets naked uniflore, leaves entire sessile, lower cuneate obtuse, upper subulate linear short, sepals lanceolate fringed at the end, rays about 4 -collected in Texas by Drummond, sent me by Torrey without name, 6 to 8 inches high, leaves small, reduced to scales above, sepals more 
scariose fewer, rays 3 to 5 , floscules 4 to 5 . 320. Laxanon diversifolium Raf. quite smooth, stem and branches flexuose, radical and lower leaves narrow pinnatifid segments oblong unequal remote falcate, upper leaves graminiform obtuse entire, umbels 2 -3flore, peduncles unequal smooth, filiform, sepals of perianthe ovatoblong obtuse-in Arkanzas, collected by Nuttal, found in Collins herb. among the Krigias as a N. G. not named: it is a second sp. of my G. Laxcinon see 204. Habit of a Krigia, lower leaves similar 4 or 5 inches long, stem pedal, leaves narrow 2 or 3 inches long, the 2 last subopposite forming a kind of involucre to the small umbellule, seeds ovate oblong striate.

321. BAPTISIA Vent. \&.c. 'This fine Genus of $\mathbf{N}$. Amer. plants had been blended with the African Sophoras and Podalyrias till lately. Even now it includes 3 or 4 distinct Genera ! Our compilers had only $8 \mathrm{sp}$. Nuttal had added 3 hardly congeneric, I shall add some others, and thus we shall have $15 \mathrm{sp}$. but now distribted in 4 Genera of which $I$ will give short monographs. They are Baptisia, Ripasia, Lasinia and Pericaulon... . . which differ more in habit and characters, than from the akin Genera Podalyria, Thermopsis, Rafnia, Templetonia, Pitcheria \&c.

Baptisia Raf. calix urceolate unequally 4 fid one tooth often emarginate, petals subequal papilionaceous, vexillum emarginate revolute vings callose or toothed inside, keel subequal obtuse, stamens 10 free unequal, style curved simple, stigma obtuse. Pod stipitate ovate or globose ventricose smooth polysperm.-Perennial plants, leaves trifoliate subsessile, not 
reticulate, stipules obsolete, flowers yellow racemose or solitary terminal, bracts obsolete.

322. Baptisia tinctoria of Authors. Raf. med. fl. tab. 14. Smooth, much ramose, terete folioles sessile obovate rhomboidal subobtuse, racemes nodding pauciflore pod turgid ovatecommon plant from Canada to Louisana in woods, but it has several varieties or deviations, some of which are assuming the rank of sp. Var. 1. procumbens, 2. thamnoides, 3. parvifolia \&ce, estival,

323. Baptisia retusa Raf. smooth folioles obovate emarginate or retuse ample, branches uniflore-this appears entitled to be deemed a sp. the leaves are 4 times as large, the flowers tivice as large, stem less ramose erect 4 feet high. Found in West Virginia and East Kentucky.

324. Baptisia spierocarpa Nut, pl, rar. 52. smooth, branches angular canaliculate, folioles sessile obovate oblong obtuse retuse, racemes erect multiflore, pods subglobose-in Arkanzas near streams, folioles uncial, flowers large deep yellow on short pedicels. In my specimens the raceme is not terminal as stated by Nuttal who first described this plant in 1834 Journ. Ac. N. Sc.

325. Baptisia albiflor $\Lambda$ Raf. Alba Authors. Smooth, branches terete, leaves on short petiols, folioles elliptic base acute end obtuse, raceme erect elongate multiflore, flowers white pods obovate-from Carolina to Alabama and Louisiana, vernal. Some Var. 1. latifolia, 2. glauca, 3. mucronata, 4. retusa $\mathscr{f} \cdot \mathrm{c}$, perhaps incipient sp. but all easily known by the fine white flowers. Perhaps a peculiar subgenus Eleucia Raf. bv nods, petiolate leaves \& $c$. 
326. RIPASIA Raf. diff. Baptisia calix campanulate base acute, petals unequal on long claws, vexillum shorter reflexed, wings longer, keel equal to vexillum, stamens subequal, stigma acute, pod oblong terete acuminate. Leaves with stipules, flowers blue racemose.-This Genus or subgenus is known at first sight by the flowers, calix, longer wings and pod, stipules \&c. The name implies its constant locality near streams.

32\%. Ripasia cerulea Raf. Bapt. Podalyria Sophora australis or cerulea of Authors. Smooth, branches terete, stipules lanceolate, leaves on short petiols, folioles sessile cuneate subacute, raceme erect elongate multiflore.On the margin of rivers from the Potomak and Ohio to Louisiana and Florida, estival. Some Var. 1. obtusifolia, 2. rhombifolia, 3. macrostachya \&c.

328. LASINIA Raf. diff. Baptisia, calix often hairy vexillum obcordate short, base auriculate, wings not callose, pistil quite hairy, style also at the base, pod subsessile, hairy oblong acuminate: Perennial plants more or less hairy, leaves reticulate with stipules and flowers with bracts or else axillary, yellowish or greyish-This group will be easily known by the hairy habit most intense in the pistil and pod, bracts, deeply cleft vexillum \&c Michaux had 3 such hairy kinds, Elliot suspected there were more, and I shall increase them to $y$ species.

329. Lasinia reticulata R. Bapt. lanceolata and uniflora of Authors. Stem smooth dichotome angular sulcate, stipules minute, leaves subsessile, folioles petiolate oblong obtuse base cuneate, minutely nervose reticulate on both 
sides, flowers axillary and subracemose bracts lanceolate-in Carolina, Florida and Alabama, leaves 2 or $\mathbf{3}$ inches long, flowers vernal dark yellow.

330. Lasinia Fulva Raf. branches terete and pubescent, stipules obsolete, leaves and folioles sessile, smooth oblong elliptic base acute, end obtuse retuse, minutely nervose reticulate on both sides, flowers chiefly axillary, some racemose, bracts oblong hairy calix pubescent pistil and pod fulvous very hairy.-Tennessee and Arkanzas. leaves uncial, flowers small of a dull fulvous yellow. A very distinct sp. probably blended among $\boldsymbol{B}$. villosa which includes several sp. according to Elliott.

331. Lasinia bicolor Raf. (or grandifolia) stem dichotome pubescent, leaves petiolate, stipules linear, folioles sessile obovate or elliptical base acute, end obtuse or emarginate, margin ciliate, pubescent beneath, reticulate above, racemes short ovate pauciflore-in Arkanzas and Texas, beautiful striking sp. leaves larger than in any other about 3 inches long, stipules petiols and calix pubescent, racemes with 8 or 10 flowers crowded large of a dull yellow with a large purplish spot at the base of the vexillum nearest to $\boldsymbol{B}$. mollis of $\mathbf{M x}$. but very different from the next.

332. Lasinia Pallens Raf. stem sulcate nearly smooth, pubescent above, stipules lanceolate, leaves sessile, folioles sessile oblong cuneate obtuse emarginate pubescent beneath, racemes oblong pauciflore, calix acute-Alabama and Apalachian mts. leaves biuncial, raceme triuncial of 10 or 12 large flowers of a dull yellow. Still nearer $L$. mollis, teeth of calix acute as in it, but very little hairy and not 
at all soft. 'The above $4 \mathrm{sp}$. are quite distinct, and may be the $\boldsymbol{B}$. villosa or mollis of some Authors, which I add here for contrast and comparison, although 1 have not seen them.

333. Lasinia cinerea Raf. B. villosa of Authors, stem and leaves beneath pubescent, stipules linear, leaves subsessile, folioles elliptic obtuse-in Carolina, Michaux says the flowers are pale, Elliot calls them grey.

334. Lasinia mollis R. Bapt. do Mx. \&o Quite pubescent soft decumbent, stipules lanceolate folioles, leaves petiolate, folioles rhomboidal lanceolate, calix acute-in North Carolina, flowers dark yellow, omitted by Elliot, discovered by Mx. found by Nuttal on the Catawba ridge, leaves 2 inches long one wide, pod small oblong acuminate.

335. Lasinia bracteata Raf. Bapt. do Mg. Elliot, \&c leucophea Nuttal \&c-quite pubescent hispid, branches angular divaricate, leaves and folioles sessile, stipules large ovate acute, folioles cuncate obtuse, racemes multiflore secund, bracts large lanceolate-from Carolina to Louisiana and Missouri, fine striking sp. folioles 3 inches long narrow, young leaves yellow beneath, flowers large on long peduncles, called ochroleucous by Nuttal, grey by Elliot, they are become brown in my Specimen. Vernal.

Decandole appears to have misunderstood some of these sp. he divides the bracteata and leucophea, while he deems the first the mollis of $\mathbf{M x}$. but has another mollis of Nuttal ....

336. PERICAULON Raf. calix campanulate unequaly 4 fid, upper bidentate, petals equal papil. not spreading, vexillum carinate $e-$ marginate amplectens not reflexed, stamens 10 
free equal, pistil stipitate, style curved, stigma acute, pod stipitate smooth subglobose acuminate swelled, seeds reniform. Leaves simple amplexicaule reticulate, flowers axillary solitary peduncled yellow-Genus quite distinct by habit, petals, stamens, pod \&c which has been shuffled by turns into Crotalaria, Sophora, Podalyria, Rafnia, Baptisia! 5 Genera ..! my name means around stem. Perennial and vernal.

337. Pericadlon perfoliatum Raf. (5 Genera do of Authors!) stem terete, subramose, leaves perfoliate rounded elliptic both ends obtuse reticulate smooth glaucous-Carolina to Florida, sandy hills, aspect of Buplevrum perfoliatum, flowers pale yellow. My specimens are from Kin, in Collins herb. Dillen and L. describe it with cordate ovate leaves, do they mean another sp? P. cordatum Raf...

338. Pericaulon microphylum Raf. Baptisia do Nut. rar. 53. stem ramose, leaves sessile obovate rounded, upper amplexicaule coalescent with rounded stipules-West Florida and Alabama, lately described by Nuttal, flowers and pod as in the last.

339. EAPLOSIA Raf. (to be simple) diff. Pericaulon, cal. camp. 4 fid subequal, petals unequal on long claws, kecl large much longer obtuse, wings oblong, vexillum obovate revolute, ovary conical desinent into a strait subulate style, stigma acute smooth. Pod substipitate conical smooth. Leaves simple sessile smooth reticulate, stipules none, flowers racemose bracteate yellow.-A fine distinct Genus by habit, petals, pod \&c: Nuttal did not see the flowers, the leaves become fuscate in drying, lucid above, dull beneath. 
340. Eaplosia ovata Raf. Baptisia simplicifolia Croom and Torrey, and Nuttal? pl. rar. 51. stem flexuose striate, leaves broad ovate quite sessile, base rounded, end obtuse or retuse, raceme spiked, bracts ovate acute longer than the short pedicels-in West Florida, discovered by Croom, specimen sent me by Torrey, sesquipedal, subramose above, leaves large 3 inches long 2 wide, raceme subterminal 3 or 4 inches long, flowers forming a spike by short peduncles, calix canescent inside, teeth large ovate, petals dull yellow. Nuttal states his specimen to have had oval rhomboidal leaves, thus nearer the next and perhaps a variety, rhomboidea.

341. Eaplosia longifolia Raf. stem flexuose sulcate, leaves oblong, elliptic subrhomboidal, base attenuate semiamplexicaule, end obtuse rounded-sent me from Alabama without flowers, but evidently akin to the last, leaves of same color and texture, minutely nervose reticulate above lucid blackish, beneath dull fuscate: but shape quite different larger 5 or 6 inches long, only 2 wide in the middle where swelled, both ends attenuated, and base a little decurrent.

342. DREPILIA Raf. calix campanulate subequal 5 fid. petals pupilionaceous subequal, vexillum revolute, stamens 10 free, style filiform stigma minute smooth, pod substipitate falcate compressed acuminate moniliform polysperm. Perennial, leaves petiolate trifoliate stipulate, flovers racemose subverticillate yellow-this Genus has been improperly united to Thermopsis of $\mathbf{R}$. Bruon which has calix bilabiate, pod linear strait \&c, a siberian G. based on Sophora fabacea. Drepilia derives from little scythe. It is very akin to Insinia. 
343. Drepilia rhombifolia Raf. Cytisus do Pursh. Thermia Nut. Thermopsis rhombif. Hooker fl. bor. t. 47. Th. oregonensis Decleaves petiolate rhomboidal silky beneath, stipules rounded foliaceous, raceme subsessile interrupted-Missouri and Origon, my specimens are from Bradburry, roots creeping, stems pedal angular.

This will conclude our Leguminose plants of Sophora tribe, the Virgilia is a tree and my N. G. Cladrastis, the Soph. sericea is subdiadelphous forming my N. G. Vexibia. I shall now give another interesting monograph of our Crotalarias.

244. CROTALARIA. Linneus had only 23 sp. we have now about 150 ! but many heterogenous sp. are blended even by Decandole, see my flora telluriana for $\mathbf{N}$. G. meantime most of our N. American sp. form a very natural group; our Authors have only 5 mostly deemed var. of C. sagittalis by Mx. some ascertained by Pursh and Elliott, but misnamed, since sagittalis, levigata and parviflora are exotic plants. I shall revise them and increase to $10 \mathrm{sp}$. having all simple leaves and long peduncles opposite to leaves, bracteate commonly multiflore, stem often winged by decurrent stipules, like a reversed arrow, mostly annuals, flowers bibracteate yellow estival. They must form a subgenus Iocaulon (arrow stem) with the similar kinds of South America \&c.

345. Subg. Iocaulon Raf. calix campanul. deeply 5fid subequal subbilabiate, equal to petals papil. Vexillum obcordate reflexed, keel acuminate longer than wings, stamens 10 monadelphous at base, split behind, filaments alternate longer beiring 5 round anthers com- 
monly sterile, $\mathbf{5}$ shorter with oblong anthers bilocular. Pistil subsessile, style lateral longer than stamens, stigma obtuse hairy, pod subsessile oblong turgid obtuse mucronate on one side black and smooth polysperm, seeds small reniform shining rattling. Habit as above stated.

346. Crot. or Ioc, linearis Raf. C. sagit. var. linearis Mx. smooth virgate erect, leaves linear elongate sessile ucute stipules linear erect hardly decurrent ; peduncles elongate triflore, bracts and calyx linear lanceolate ciliolate, pods subterete-from Carolina to Louisiana, received from Alabama, annual, estival, stem erect slender pedal, leaves long narrow, 2 or 3 inches long, stipules weH marked, peduncles very long 4 or 5 inches, with 1 or 2 bracts in the middle, flowers small near together. Pods longer and narrower than in the others, nearly terete oblong quite black.

347. Crot. or Ioc. LongIPEs Raf. sagittalis?

Dec. smooth assurgent, stem well winged, leaves sessile narrow lanceolate acute, stipules lanceolate erect foliose decurrent, peduncles very long incurved biflore, bracts and calix linear lanceolate hispid-sent me from Alabama, large bipedal, leaves 3 or 4 inches long, half inch broad, stipules large uncial, peduncles 6 to 8 inches long, with a bract in the middle, flowers small, pods not seen.

348. Crot. or Ioc. pilosa Raf. parviflora Roth Dec. P. El. \&c. excl. syn. Mx. non parvifl. Thunberg. W. Sm-erect ramose, pilose hirsute, leaves subsessile oblong lanceol, ciliate mucronate. stipules short irregular subdecurrent, peduncles short subracemose 3-5flore, bracts and calix ciliate linear lanceol. pods turgid oblong-from Pensylv. and New Jersey to 
Carolina and Missouri, small semipedal, leaves short uncial, peduncles biuncial flowers small, petals shorter than calix, porls brown. The Cr. parviflora Thunberg, miscalled parvifolia by Persoon is African and has ovate tomentose leaves. Annual estival, some Var. 1 Simplex leaves mostly oblong, in Pine Woods, 2 flexuosa lower leaves oblong obtuse, upper narrow lanceolate, Missouri. Formerly this was called C. sagttalis, and Beck, Torrey, Eaton... make $2 \mathrm{sp}$. of it, without any distinction!

349. Crot. or Ioc. cuneifolia Raf. Purshi Dec. levigata? Pursh. sagittalis Elliot. Smooth erect, leaves cuneate oblong mucronate glaucous beneath, upper leaves ciliolate, stipules lanceolate divaricate decurrent, peduncles short 2-3fl. pubescent, bracts and calix lanceolateCarolina to Florida, sent me as Cr. sagittalis, probably blended with the next by Elliot, leaves biuncial quite cuneate at base, stipules broad, flowers small.

350. Crot. or Ioc. lunulata Raf. sagittalis var. oblonga $\mathbf{M x}$. stem assurgent pilose ramose, leaves subpetiolate nearly smooth elliptic or ovatoblong obtuse cuspidate glaucous beneath ciliolate, stipules lunulate lanceol. decurrent ciliate, peduncles short 1-2flore, bracts and calix lanceolato pilose, pod uncinate-Carolina to Florida, my specimen from W. Florida, large plant sesquipedal, branches erect, leaves uncial, flowers small, peduncles biuncial, pods brown uncial oblong, with a hooked acumen. Stipules quite crescent shaped, very distinct sp. probably perennial like the next.

351. Crot. or Ioc. ovalis. P. El. \&c stem pilose prostrate, branches angular erect not winged, leaves ovate or obovate or elliptic 
smooth ciliate subpetiolate obtuse or retuse glaucous beneath, stipules minute not decurrent, peduncles elongate racemose 3-6flore, bracts linear calix hirsute lanceolate, pod obovate-from Carolina to Florida and Alabama, stem sesquipedal, leaves uncial or less. peduncles 4 to 8 inches long, petals exceeding a little the calix, pods uncial. Perennial, some Var. 1 Obovata many leaves obovate, 2 parvifolia \&c.

352. Сrot. or Ioc. pumila Raf. Dwarf prostrate branches flexuose hispid diffuse angular, leaves elliptic rounded subsessile obtuse or retuse rugose, stipnles obsolete, peduncles very short uniflore, bracts linear, calix lanceolate hirsute-Florida and Georgia, perennial, only 2 or 3 inches high or long, leaves and flowers very small. Habit of Polygonum aviculare. Probably a deviation of the last.

353. CRot. or Ioc. sagittalis L. \&c stem erect hirsute winged above, leaves lanceolate petiolate hairy beneath, stipules bifid decurrent peduncles racemose-in Guyana and Brazil, quite different from all ours. Decandole appears to omit it, and applies the name to ours, perhaps to $\mathbf{3 4 7}$.

354. Crot. (Ioc?) Flexuosa (Eaton.) Suffruticose, branches flexuose, leaves obovate dentate hairy, flowers corymbose downy-Carolina, quite distinct since shrubby with toothed leaves: not seen, I find it only in Eaton, who forgets to quote the Author.

355. Crot. (Ioc?) scariosa Raf. suffruticose branches erect simple slender terete silky, leaves adpressed sessile lanceolate acute entire, silky white beneath, peduncles subradical with scariose scales, flowers subcapitate, involucre 
scariose, bracts and calix broadly lanceol. silky-Texas and Arkanzas, submulticaule 5 or 6 tuches high, only woody at the base, no stipules, floriferous stems or peduncles 3 or 4 inches long, scales fulvous vaginate, flowers 5 or 6, yellow, vexillum large round longer than calix.

356. Crot. (Ioc?) asarifolia Raf. Prostrate puberulent, stem simple slender angular not winged, leaves on long petiols broadly cordate obtuse entire, stipules obsolete, peduncles axillary short 1-2flore, bracts and calix lanceolate-'Texas, collected by Drummond, a very distinct sp. by petiolate leaves, probably not a Iocaulon, yet flowers similar small, petals equal to calix, annual? leaves remote petiols uncial, leaves one inch broad but shorter, pods not seen.

357. Crot. (Ioc?) alatipes Raf. smooth, stem angular flexuose, leaves on winged cuneate petiols, oblong acnte base subcordate, reticulate above, stipules lanceol. scariose striate, flowers racemose terminal, bracts similar to stipules equal to pedicels-South Florida, herb. of Collins, not named, evidently of this group, but not a Iocaulon! probably a peculiar subgenus (Alatipes Raf.) calix short with a subulate calicule beneath, petals subequal, keel quite curved acute, vexillum reflexed, pod not seen. It must be compared with the tropical sp. Quite smooth all over, perennial, leaves rigid 2 or $\mathbf{3}$ inches long, petiols uncial, some lower leaves smaller oboval retuse, spikes slender curved 3uncial, flowers small saftron yellow.

Decandole has another from N. Amer. Crot. platycarpa of Link. which hardly differs from Cr. pilosa, and is probably var. simplex, by its 
oblong leaves; the name of platycarpa is an absurdity in a Genus having always turgid pods : if really with flat pods it is not of this Genus!

358. GERARDIA AND AKIN GENERA-Sir James Smith has stated in Rees Cycl. that this Genus of P'lumier was based on the G. tuberosa only, and that Linneus in adopting it had united thereto many plants that ought to be separated if with different characters: this is the fact with all our North American sp. which must even form 3 or 4 peculiar Genera. Nuttal deemed them confused, forming 2 sections with purple and yellow flowers as near Digitalis as Gerardia! I have reformed this G. in flora Tellur. I now mean to revise all our species, which I mostly possess and amount to over 20 . Some of these were once united to Rhinanthus Chelone and Erinus! but Seymeria, Pagesia, Dasistema,and others, have been already distinguished. I shall add many others.

Character of real Gerardia. Calix 5 fid, corolla tubulose bilabiate, upper lip emarg. erect, lower 3lobe, reflexed, middle lobe bifid, lateral lobes emarginate. Stamens 4 didynamous smooth, anthers smooth, a style, stigma obtuse. Capsule bilocular oligosperm, partitions contrary to valves, dehiscent below. Roots tuberose, leaves opposite entire, flowers axillary yellow. Several tropical sp. blended in G. tuberosa.

359. Lopuntuera Raf. differs by corolla campan. 5lobed, the anthers crested, leaves divided \&c. Type G. delphinifolia of Asia foc. The African sp. form the G. melasma of Berg.

360. AUREOLARIA Raf. calix campanul. 
semi 5 fid subequal segments simple, corolla campanul. ventricose, limb 5lobed obliqual,lobes subequal entire. Stamens 4 didyn, filaments hairy as base, anthers hairy not crested, base bifid biaristate. Capsule dehiscent above. Roots perennial, leaves opposite, flowers terminal bracteate yellow-This will include nearly all our golden sp. except G. pedicularis \&c. The name implies the golden flowers.

361. Aurfolaria villosa Raf. Ger. do Muhl. Ger. flava L. \&c. Easily known by its pubescence often all over, leaves oblong, the lower sinuate. Several var. 1. virgata, 2 sinuata, 3 montana all leaves entire, 4 heterophyla Mg. leaves very different and sinuate.

362. Aureolaria levigata Raf. Gerardia do Raf. annals Nat. 99, G. lanceolata Muhl. Cat? Quite smooth, leaves subsessile lanceolate acute entire, pale beneath, bracts ovate lanceolate, flowers subsessile, teeth of calix ovate obtuse-in the Mts. Alleghanies and Cumberland from Pennsylv. to Kentucky, disc. by me 1818 descr. 1820 in my annals, stem 1 or 2 feet high mostly simple faintly 4 gone purplish, bracts small, flowers large yellow estival. Var. 1. ramosa, 2 alternifolia some leaves and most of the flowers alternate.

363. Aureolaria reticulata Raf. stem assurgent terete smooth simple, leaves sessile oblong and cuneate entire acute, rough above and on margins, beneath smooth reticulate, flowers racemose peduncled, bracts linear cuneate, teeth of calix ovate acute-Florida and Alabama, pedal, stem dark purple, leaves biuncial.

364. Aueneolaria cuneifolia Raf. smooth, stem simple terete, leaves sessile cuneate acute 
sinuate dentate, flowers racemose, bracts linear entire, peduncles equal to calix. segments lanceolate-Mts. Alleghany rare, stem pedal dark purple, leaves 2 to 4 inches, upper narrow, calix broadly camp. subbilabiate, corollas large. Very different from Gerardia cuneifolia of Pursh, nearer to A. glauca.

365. Aureolaria rupestris Raf. Ger. do. R. Atl. Journ. p. 154. quite smooth, stem fistulose purplish, leaves petiolate bipinnatifid segments deep lanceolate acute remote, sinusses rounded, upper leaves oblong pectinate lacininiate. racemes often ramose, bracts lanceol. entire, flowers secund peduncled, segments of calix lanceol. acute-in the Alleghany Mts. on rocks, Tuscorora chain \&c, probably blended with the next by Authors, 2 or 3 feet high, often ramose, leaves large below and twice cut, narrower above, flowers smaller than in the other kinds.

366. Aukeolaria glauca Raf. Ger, do. Eddy, Eaton, Tor. Beck. G. quercifolia Pursh, Elliot. G. flava Walter, Rhinanthus Virginicus L.-Quite distinct from the last by larger size, stem solid glaucous, leaves subsessile the lower sinuate pinnatifid, attenuate at both ends, a little rough, upper entire, raceme paniculate, bracts linear, segments of calix linear elongate - from Isong Island to Carolina and West in the prairies of Kentucky, where it attains 6 feet var. 1. Gigantea, 2 purpurea stem purplish.

367. PANCTENIS Raf. (quite combed) diff. Aureolaria, calix urceolate 5fid segments unequal foliaceous pectinate or crenate. Corolla hairy outside, stamens quite hairy, capsule polysperm. Flowers axillary, this may 
be deemed a subgenus of the last if liked, but is very distinct and may as well be a Genus.

368. Panctenis penicularis Raf. (or Aureolaria) Gerardia do L. \&c. WVell known common species very branched and clammy villose, segments of calix crenate serrate or laciniate. Var. 1 ramosissima, 2 pumila, 3 simplex ofc, but 2 other varieties appears to be wide deviations and incipient sp. sprung from this.

369. Panctenis pectinata Raf. Ger. pedic. var pectinata Nut. leaves ovate pectinatly subbipinnatifid softly villose, peduncles short, segments of calix pectinate-found by Nuttal in pine woods of Carolina, by myself in pine woods of Alleghanies, sesquipedal.

370. Panctenis pumila Raf. dwarf, leaves lanceolate, crenate or pectinate hardly pinnatifid, petiols elongate, segments of calix only crenate-Alleghany Mts. found in bloom later than any other in Autumn, roots large thick branched, stem only 3 inches high, leaves small not bipinnate, flowers as large as usual. whole plant quite hairy but not clammy. Could it be a late Autumnal shoot thus deviating to form a peculiar species?

371. AGALINIS Raf. (remarkable flax.) Calix campanul. 5 dentate, often truncate, teeth subequal not obliqual. Corolla widely campanulate 5 lobes rounded equal obliqual often ciliate. Stamens didyn. villose, anthers bicuspidate at base, dehiscent lateraly. A style, stigma obtuse compressed. Capsule globose bilocular, bivalve quite split, polysperm. Chiefy annuals, slender stems and leaves, flovers axillary and terminal purplish-a very distinct natural Genus having the habit of flax, 
with toothed calix and purple flowers estival and Autumnal, leaves and flowers chiefly opposite, leaves always sessile.

372. Agalinis Palusiris Rat. Ger. purpurea L. \&c. that name applied to all. It will be known by its locality near marshes, stem branched rough 4 gone, leaves broad linear rough, flowers subsessile and large, teeth of calix elongate and broad. From New England to Carolina, sesquipedal. Var. Corymbosa branches crowded corymbose, 2. divaricata slender divergent, 3 ramosissima, 4 virgata \&c, but the next appears to be distinct.

373. Agalinis longifolia Raf. stem simple 4gone smooth, leaves long linear smooth thin margin rough, flowers subsessile, teeth of calix long subulate,-Near streams New Jersey to Virginia, stem $\mathbf{6}$ to $\mathbf{1 2}$ inches only, while leaves $\mathbf{2}$ or $\mathbf{3}$ inches long, often aiternate above, flowers rather large.

374. Agalins inatima Raf. Ger. do Raf. med. rep. 1808. Nuttal 1818. G. purpurea var. crassifolia Pursh. Quite smooth, stem branched, leaves linear thick convex beneath enerve, flowers on peduncles shorter than leaves, calix crenate, teeth short obtuse-on the Sea shores from New England to Chesapeak bay. Stem 2 to 8 inches high, flowers smaller. A very distinct sp. one of the few of my early discoveries in 1802 adopted by our botanists. Var. 1. purnila, 2 or 3 inches high, 2 gracilis less branched slender leaves remote.

375. Agalinis virgata Raf. quite smooth, stem simple virgate angular, leaves adpressed narlow linear, flowers racemose opposite on short peduncles, teeth of calix short acuteglades of Pine woods in South New Jersey near 
Mullica Hill \&oc, annual, estival, 6 to 15 inches high, leaves short semiuncial equal to internodes, shorter or remote above, flowers size of $\mathbf{A}$ maritima, peduncles eqnal to calix. 'I'his is most likely the erecta of Walter.

376. Agalinis corymbosa Raf. stem smooth angular filiform branches terminal corymbose virgate leaves adpressed setaceous linear scabrous with a thick nerve, flowers alternate subsessile, teeth of calix broad acute-Carolina and Florida, stem 1 or 2 feet very slender, leaves small semiuncial, flowers rather large. It appear to differ from the G. plukeneti of Elliot by the leaves, rough and broader, less branches, shorter peduncles and alternate flowers.

37\%. Agalinis plukeneti Raf. Ger. do Elliot. Pluk. phyt. t. 12. f. 4. not seen by me, appears to differ from last by stem much branched, setaceous smooth leaves, peduncles longer. Carolina.

378. Agalinis perennis Raf. Ger. linifolia Nut. El. \&c Perennial creeping roots, stem terete virgate smooth, few virgate branches, leaves smooth long linear thick, flowers terminal racemose smooth, peduncles subequal to the upper leaves, teeth of calix remote short acute-Carolina to Florida, a very distinct $\mathrm{sp}$. from my A. virgata, nearer $A$.maritima ; distinct from all by the roots that are annual in others. My specimen is from Florida, and has leaves nearly 2 inches long, rather divergent, flowers few remote, corolla smooth not pubescent and ciliate as in most species, peduncles nearly uncial.

379. Aganinis fasciculata Raf. Ger. do Elliot. I have not seen this sp. but it appears 
to differ fiom all mine by the tall rough rigid stem 3 to 5 feet high, leaves opposite and ternate with axillary fascicles, rough linear, flowers subsessile and teeth of calix linear longer than in any-Sea Islands of Carolina.

380. A galinis tenuifolia Vahl. and all bot. but Elliot suspects some sp. are blended sinee Nuttal calls the leaves rough, but his own specimens in Collins herb. are smooth. Easily known by complete smoothness stem 4gone, leaves linear, corolla short small smooth, peduncles as long as leaves, teeth of calix small acute-from Canada to Florida and Missouri, autumnal, woods and glades var. 1 paniculata 2 ramosissima 2 feet high Elliot. 3 humilis semipedal few branches, 4 saxatilis leaves longer, branches divaricate.

381. Agalinis setacea Raf. Ger. do Pursh. smooth, stem subramose terete filiform, leaves setaceous, peduncles filiform longer than leaves corolla short, teeth of calix minute acuteNew Jersey to Alabama and Kentucky, Illinois in glades,flowers as in the last. Var. humilis 6 to 10 inches, 2. major 1 or 2 feet more branched.

382. Agalinis obtusifolia Raf. quite smooth and glaucous, stem subramose angular filiform, leaves setaceous sulcate, end obtuse callose, flowers racemose, peduncles much longer than leaves, corolla short, teeth of calix minute remote callose-West Tennessee, Alabama and Florida, distinct from last by angular stem and leaves with a deep furrow, obtuse at the end, all other kinds have acute leaves. Stem with few slender branches, leaves and flowers often alternate; corolla smooth shallow or broadly campanalate. 
383. Agalinis filifolia Raf. Ger. do Nut. Ell. I have not seen this sp. of Florida, it appears to differ by terete stem, leaves filiform, carnose, corolla large similar to A. palustris, calix likewise.

384. Agalinis microphylla Raf. smooth, stem virgate terete costate sulcate, leaves remote adpressed scattered minute linear obtuse, flowers spicate subsessile, peduncles shorter than calix, teeth short acute, corolla smooth ciliate shallow-in Florida, collected by Leconte (Collins herb) very slender, few alternate branches, few leaves 2 or 3 lines long, stem deeply grooved and ribbed not angular. Flowers small similar to those of $\boldsymbol{A}$. glauca. Quite distinct from next by stem, leaves and peduncles.

385. Agalinis aphylla Raf. Ger. do Nut. El. smooth, stem virgate nearly simple 4gone leaves opposite like scales ovate acute deciduous, flowers racemose opposed, peduncles elongate triple of calix, teeth minute acuteCarolina to Florida. My specimen is only pedal,and in fruit, quite aphyllous, capsules ovate, there are 2 other doubtful sp. of this Genus, Ger. leucanthera fl. lud. 155, which is probably a var. of Ag. tenuifolia G. 2. Ger. flammea of Bartram travels omitted by all later botanists, is perhaps a Russelia! for G. auriculata see next Genus.

386. TOMANTHERA Raf. calix 5parted unequal, corolla smooth venose, rotate campanulate 5lobed, lobes rounded 2 superior larger, stamens 4 didynamic very unequal, 2 of double length,filaments smooth flexuose,anthers smooth bipartite, the 2 cells unequal,dehiscent lateraly, style flexuose, stigma obtuse. Capsule ovate 
acute bivalve as in Agalinis. Same habit annuals, leaves opposite sessile, flowers axillary purplish-A very distinct $G$. by calix, stamens and anthers, corolla as in Seymeria, but purple. 'The name applies to the split anthers.

387. 'Tomanthera lancelata Raf. Erinus! africanus Muhl. stem simple hirsute, leaves lanceolate acute entire pubescent, flowers subsessile, segments of calix ovate lanceolate pubescent-A very rare plant deemed doabtful because never described. In Pensylv. and Carolina, my specimen of Collins herb. was collected by $\mathbf{D r}$. Cleaver in New $\mathbb{J}$ ersey, it is annual only 4 inches high, with a thick stem of a dark purple, leaves few small 4 to 8 lines long, flowers large, size of Agalinis tenuifolia, calix subfoliose, corolla smooth. Never met by me in 25 years of researches!

388. Tomanthera? auriculata Raf, Gerardia do Mx. and all our copists, who have never seen it nor described it! by Michaux short account it differs by stem nearly simple very rough, leaves ovate lanceolate auriculate, flowers quite sessile-in Illinois and also Louisiana: I have not seen it and it must be better described.

389. DASISTEMA Raf. J. Sc. phys. 1819. Calix urceolate 5fid, segments unequal foliaceous dentate. Corolla with a short thick tube wooly inside, limb rotate 5lobed, lobes subequal concave wooly at the bottom. Stamens 4 didyn short wooly, anthers mutic smooth. a 5th sterile stamen, style short, stigma clavate. Capsule as in Aureolaria, seeds winged. Perennials, leaves divided opposite, fiovers spicate bracteate yellow.-This N. G. of mine disc. 1818 published 1819 with my $50 \mathrm{~N}$. G. is quite pe- 
culiar having the calix of Panctenis, but stamens unlike all.

360. Dasistema auriculata Raf. quite villose, stem 4 gone ramose, leaves petiolate broadly lanceolate, the lower auriculate at base, medial truncate at base, upper acute at base, all crenate serrate subobtuse, bracts sessile ovatoblong, flowers subsessile, calix crenate-on the banks of $\mathbf{R}$. Ohio in West Kentucky and Illinois, estival, fine plant 3 or 4 feet high, leaves 2 to 4 inches long, flowers large golden yellow.

391. Dasistema macropuylla Raf. Seymeria do Nuttal foc Erinus pinnatif? Mg. stem ramose, leaves nearly smooth subsessile, lower elongate pinnatifid or sinuate, upper lanceolate entire, flowers subsessile, segments of calix entire ovate - found by Nuttal in Ohio, I have his specimen in Collins herb. whereby I have ascertained what I already surmised, that it is really a sp. of this Genus and not Seymeria, Nuttal says the stamens are smooth, but involved in the wool of the base, he meant the anthers, the filaments being also wooly. Tall plant, leaves 3 to 6 inches long, flowers yellow. 392. SEYMERIA Pursh. Afzelia Gm. not Smith. Calix camp. deeply 5fid. subequal. corolla rotate campanulate deeply 5lobed, lobes subeqnal, stamens 4 very short subequal quite smooth, except at insertion subsessile deflexed anthers oblong smooth emarginate, incumbent, two equal cells opening by ovate terminal pores. Style filiform declined, stigma obtuse. Capsule bivalve ovate 2loc. polysperm, seeds minute. Annuals, leaves opp. and alt. small divided, flowers axillary yellow-a very distinct Genus mistaken by Nuttal who gave the character out 
of his S. macrophylla, the stamens and pores are quite different. Elliot has better uuderstood the characters and the $3 \mathrm{sp}$. which I all possess.

393. Seymeria tenuifolia Pursh. N. E. \&c. Afzelia cassioides $\mathbf{G m}$. Gerardia afzelia Mx. branches terete rough, leaves smooth setaceous lower pectinate pinnatifid, upper subentire, flowers racemose, peduncles subequal to leaves, segments of calix linear-Carolina to Alabama, stem 3 or 4 feet (Elliot) much branched, small slender leaves, calix quite cupular at base with rounded sinusses and linear segments, corolla with purple dots inside, segments oblong obtuse, capsule smooth.

394. Seymeria pectinata Pursh \&oc, Viscose pubescent leaves pectinate pinnatifid, segments of calix cuneate-Carolina to Florida, although Nuttal calls this common, Elliot did not see it, and I have fewer specimens than of the last. Branched, leaves short, calix with deeper and broader segments, sinusses obtuse, corolla and capsule pubescent.

395. Seymeria heterophyla Raf. S. jacksoni $\mathbf{E}$. viscose pubescent, branches virgate, leaves oblong lanceolate, lower pinnatifid segments oblong the last larger, upper leaves entire or auriculate, peduncles equal thereto, segments of calix oblong deeply parted-a very distinct sp. which Elliot deemed doubtful. Alabama and Georgia, my specimen from Leconte C. H. 2 to 4 feet high, branches incurved subterete, leaves minute very short, calix almost 5parted, corolla small segments ovate obtuse, style short.

396. DASANTHERA Raf. 1817. Calix 5 parted unequal, corolla campanul. 5lobed une. 
qual, stamens 4 unequal, anthers villose. Leaves opposite serrate, flovers purple-to complete the compared account of all the Gerardias I add this Genus, with some others not seen by me, and very little known, which must be described better hereafter. This appears medial between Aureolaria and Dasistema, but the calix and purple corollas differ from both.

397. Dasanthera fruticosa R. Gerardia do Pursh \&c shrubby, leaves lanceol. serrate subpetiolate, flowers racemose bracteate.-Origon Mts. only seen dry by Pursh and Torrey.

398. Dasanthera? cuneifolia Raf. Ger, do Pursh ofc perennial, branches erect, leaves cuneate unequaly serrate, upper alternate, peduncles axillary longer than leaves or bractsFlorida, disc. by Bartram but not his flammea, of doubtful G.enus not even seen by Elliot. Calix 5parted and purple flowers.

399. PAGESIA Raf. fl. lud. calix 5parted unequal, upper segment larger, corolla tube ventricose limb rotate bilabiate, upper lip reflexed flat emarginate, lower trilobe. Stam 4 didyn. style and stigma simple, capsule as in Auredaria. Leaves oppos. sessile, flowers racemose white-This $G$. of mine 1817 is akin to all the above, but distinct by the calix bilabiate, white corolla of c.

400. Pagesia leucantha Raf. fl. lud. 149. Stem weak decumbent 4 gone ramose, leaves sessile ovatoblong serrulate smooth, axils biauriculate, flowers racemose on long peduncles, segments of calix striate-in West Louisiana and Texas probably, disc. by Robin, many weak stems pedal, white smooth flowers, capsule oval polysperm. This may be the white flowered Ger. auriculata of Louisiana hinted at by some botanists. 
401. OVOSTilis Raf. Cal. campanul. 5 fid, segments unequal leafy entire. Corolla tubular ventricose smooth limb large spreading with 5 lobes subequal rounded. Stamens 4 didyn. included, filaments subequal smooth; anthers obtuse base sagittate bifid bicuspidate 2locul. opening latera!y, sutures pubescent. Style elongate strait, stigma capitate ovatoblong acute nodding. Capsule sinall inclosed. $\boldsymbol{H} e-$ rennial? lcaves opposite petiolate, flowers axillary white-a singular Genus partaking of the characters of many akin, but distinct by calix, stigma and white flowers as in Pagesia. The name means ovate stigma.

402. Ovostima petiolata Raf. quite smooth stem simple terete purplish, leaves opp. petiolate oblong lanceolate both ends acute, lower repand or with remote unequal obtuse teeth, upper subentire, flowers subsessile, segments of calix ovatoblong-Florida or Alabama, received without name with many other rare plants. I first called it Aureolaria pallida, but have been able to ascertain it since as a N. G. near $\mathbf{P a -}$ gesia; I have not the ripe fiuit however. Stem sesquipedal, leaves thin pale beneath 2 or 3 inches long, flowers large nearly 2 inches long, segments of calix longer than camp. base, corolla thin apparently white or very pale ochroleucous.

403. RUSSELIA Jaq. Jus. W. not of Lin. junior which is Vahlia. Calix 5parted, corolla tubulose limb spreading bilabiate, upper lip emarginate, lower longer trilobe stamens $\mathbf{4}$ didyn. inclosed. Capsule acum. subuniloc? valves inflexed. Leaves oppos. peduncles axillary flowers red or scarlet-this fine tropical Genus must be added to our Flora. Gal- 
vezia of Dombey in Jussieu united thereto by W. P. differs by calix 5 fid, tube ventricose below and capsule globose.

404. Rinsselia juncea. Zuc. in bot. reg. 1773. Branches 4gone erect virgate, leaves minute petiolate ovate subentire, peduncles filiform subbiflore-'Texas and Mexico, flowers scarlet.

405. Russelia flamia Raf. Gerardia do Bartr. trav p. 412. stem ramose pyramidal, leaves lanceolate? flowers in a pyramidal foliose panicle-Alabama, indicated 60 years ago by Bartram, and still not in any work nor garden as yet: although a splendid plant 4 feet high, crowded with large scarlet flowers, tubular and bilabiate; therefore referable to this Genus, unless it is a new one to be called $F_{\text {LA- }}$ MARIA COCCINEA Raf.

406. MACR ANTHERA 'Torrey 1835. Conradia Nuttal 1834 but not of Martius. Calix deeply 5fid, corolla tubular border 5fid subequal. Stamens 4 subequal exserted, filaments hairy, anthers linear sagittate. Style long filiform, stigma simple or bifid. Capsule ovate acum. polysperm, as in Aureolaria. Perennials, leaves opposite dirided, flowers axillary racemose yellow on long refiexed incurved peduncles.-I adopt the namie of Torrey instead of Conradia already twice employed, by myself in 1825 for my Leptiix Neog. 25 for the American Tofieldas, sec Abama 1st part, and also by Martius, Hacranthera is not however a very good name as the anthers are not very long, the name of 'Toxores (Paf.) meaning incurved peduncles would have been better, but the 2 sp. known (and there may be more) ap- 
pear types of two subgenera differing as Pnnctenis and Aureolaria.

407. Macranthera Leconti Torrey (or Toxopus gymnanthes Raf.) leaves smooth petiolate ovate lanceol. sinuate pinnatifid, bracts and segments of calix linear lanceolate entire in Florida and on the R. Alatamaka, 2 or 3 feet high, flowers autumnal deep yellow. Torrey states the stigma to be simple and yet his figure shows it quite bifid and bilamellar.

408. Macranthera fuschioides ' 1 '. Benth (or Toxopus calycinus or Tomilix bracteata Raf) Conradia Nut. rar. 41. fig. Smooth leaves petiolate lanceolate sublyrate pinnatifid, bracts ovate sinuate, segments of calix lanceolate unequal foliose serrate-in"Alabarna, fine large plant with golden flowers, the calix is nearly as in Panctenis, and the stigma certainly simple, these two characters indicate a subgenus if not a Genus! my 'Tomilix meaning cut calyx.

409. APENTOSTERA Raf. (no fifth sterile) Calix 5 parted subequal, corolla ventricose campanul. bilabiate, upper lip erect bilobe, lower trilobe. Stamens 4 didyn. anthers villose, no fifth sterile filament. Capsule ovate acute, seeds angular not winged. Leaves opposite, flowers axillary, racemose purplish-this $\mathbf{N}$. G. of Origon is probably fecond in sp. It links the Gerardia group with the Pentostemon. Totaly unlike our real Chlonanthus (chelone) having the corolla convex short and winged seeds. Pentostemon which now includes a crowd of sp. that must be divided into 5 Genera, differ by the fifth filament and various corollas. Also near to Pagesia.

410. Apentostera secundiflora Raf. Pen- 
tost. scouleri Lind. bot. reg. 1277. Suffiruticose, leaves cuneate serrate, upper linear obtuse entire, flowers subracemose secund-Origon, large purple flowers. Akin to Dasanthera fruticosa 397.

411. Apentostera triflora Raf. Chelone! nemorosa Lind. bot. reg. 1211. Herbaceous, leaves ovate acum. serrate, upper amplex. cordate, peduncles axillary triflore-Origon, quite similar to the last in the structure of flowers, yet put into a different Genus by Lindley!

412. LEPTEIRIS Raf. (minute sterile) calix 5parted, corolla tubulose incurved bearded inside, limb 5lobed subequal. A minute rudiment of a fifth sterile stamen. Leaves oppos. narrow, flowers glomerate verticillate whilish - another and nearer link to Pentostemon, distinct from it by corolla and habit quite peculiar : akin to Russelia and Pagesia.

413. Lepteiris parvirlora Raf. Pentostemon micranthum Nut. cat. 83. Smooth, leaves linear lanceol. acute entire subamplex. flowers spicate paniculate glomerate in whorls, segments of calix lanceolate-Origon, stem slender pedal, seen dry, collected by Wyeth.

I must end here this long survey of the Genera akin to Gerardia, without attempting yet all those akin to Pentostemon. 'They are further removed from Digitalis to which Nuttal compared them. Thus we have already 12 Genera and $40 \mathrm{sp}$. of plants akin to Gerardia or once added thereto, many of which are quite rare plants seldom seen by our botanists; some are beautiful and yet hardly known in Gardens. There must be others in the Missouri and Origon regions. It is a fact that in this tribe the colors of flowers indicate Genera! I have not 
yet seen the labor of Hooker on the Gerardia. 414. Schwalbea Americana I.. \&c. I have several specimens of this fine and rare plant, collected from New Jersey to Carolina ; yet $\mathbf{I}$ never could meet it myself in $\mathbf{2 5}$ years of botanical herborizations! I mention this to show again how easy it is for careless botanists to overlook my new and rare plants or blend them with others, if such plants escape my keen researches. Well described by Elliot. T'he alternate leaves and capsule with partition formed by the valves, remove this $G$. from the group of Gerardias.

\section{MONOCOTYLES.}

Although 1 wish to be concise I have been compelled to dwell upon some Genera improperly known, and thus give again monographs instead of mere insulated new species; this plan will be preferred by those who like to compare the whole at once. Having till now described Dicotyles only, I now mean to give some new or rare Monocotyles in the remainder of this second part of my Fora ; the third part whereof will be chiefly upon trees and shrubs.

415. UNISEMA Raf. 1803. Med. fl, 1830. Fl. tell. 6. Beautiful distinct Genus of mine based on the various species blended in Pontederia cordata! with a fruit quite peculiar similar to Grasses! which our botanists have hesitated to adopt, altho' they knew it was guod, having verified the fruit!-Perigone corolliform bilabiate 6 fid, stamens 6 unequal filiform 
incurved. Style filiform, stigma simple. Fruit a single oblong seed covered by the marcescent 6 ribbed perigone, perisperm farinaceous, embryo fleshy central terete. Aquatic plants, roots fleshy creeping, leaves radical petiolate, stem unifoliate articulate, spadix terminal spicate with a vaginal spatha below the base, flowers blue.-Thus quite a natural Genus, widely different from Pontederia and the akin Genera Kadakia, Carigola, Gomphima, Piaropus, Lunania or Endolimna see my flora tell. This forms the type of a peculiar family UNISEMIDes 1815 near to Aroides and Typhacea, the spike is a real spadix. I have given a long history of this G. in my Medical flora.

416. Unisema deltifolia Raf. m. fl. fig. 93. Radical leaves oblong deltoid obtuse, base acute or truncate, stem leaf subsessile similar undulate base subreniform; spike terete, peduncle subequal to spatha, segments of flowers oval obtuse-in West Kentucky, Tennessee, Alabama and Florida. Stem $\mathbf{3}$ feet, leaves 5 to 8 inches long, spke 3 inches.

417. Unisema Peduncularis Raf. purshiana? Raf. m. fl. (angustifolia? Pursh) This differs from last by leaves truncate or subcordate the stem leaf on a long petiol, the peduncle of the spike twice or thrice as long as the spatha, segments of flower linear lanceolate-Carolina to Florida. Spike shorter hardly 2 inches. Var. parvifolia, leaves 3 or 4 inches long only, spike only one inch, peduncle and petiols not quite so long. My specimens of both have all obtuse leaves, none are acute.

418. Unisema media Raf. $m$. fl. 3 . Leaves oblong cordate obtuse consimilar, spike terete peduncle longer than spatha, segments oblong 
obtuse-New York to Carolina, called P. an. gustif. by many, not at all deltoid, lobes deep rounded, breadth of leaves about one third of length. spikes 2 or 3 inches long. Var. angustifolia leaves still narrower, Var. albiflora with white flowers.

419. Unisema acutifolia Raf. 6 P. cordata Lamark. Leaves cordate acute, spike terete, segments oval oblong-Carolina found by $\mathbf{H}$ osc, I have not seen it yet, is it a Var. of U. latifolia?

420. Unisema heterophylla Raf. 8. Leaves oblong lanceolate obtuse, base subcordate or truncate, stem leaf cordate on long petiol, spike oblong, peduncle equal to spatha, segments linear oblong-New York to Louisiana, found at Trenton falls of Delaware and on the R. Ohio, a small plant, 12 to 18 inches high, leaves 1 to 3 inches long very narrow, therefore the $\mathbf{P}$. angustif. of some botanists. Var. lanceolata, 2 stenocardia.

421. Unis. lancifolia Raf. fl. tex. 27. Pont. lanceolata Mg. Elliot. Leaves linear lanceol. base rounded or acute, end acute-Florida to Texas. Leaves 3 or 4 inches long broader than in last, sometimes ovatoblong, but really acute.

422. Unis. obliquata Raf. m. fl. 4. Leaves more or less obliqual with unequal sides, obtuse oblong cordate or subhastate, spikes ovatoblong peduncles equal to spatha, segments linear obtuse-from New Jersey to Virginia, about 2 feet high, leaves 4 to 6 inches long, spikes one inch.

423. Unis. latifolia Raf. 5. Pont. cordata of most botanists. Leaves ovate broadly and deeply cordate very obtuse, spike oblong terete 
peduncle equal to spatha, segments oval-the most common kind from New Jersey to Flori$\mathbf{d a}$, in marshes and streams, 3 to 5 feet high, leaves nearly as broad as long. Var. 1. Elatior, 2 undulata, 3 pallida, 4 albiflora . 90.

424. Unis. mucronata Raf. $1808 \mathrm{~m}$. f. 7. Leaves narrow oblong, base broader cordate; end with a long obtuse point, spike terete, segments oblong-found by Mr. Hingston in Virginia 1800, seen in his herbal.

425. Unis. Rotundifolia Raf. m. fl. 9. Leaves rounded obtuse hardly cordate at base, spike oblong, segments oval-Kentucky and Illinois. Stem weak, one foot high, leaves small about 2 inches. Not the Ponted, rotundif. of Linneus and South America,which appears the real type of Pontederia having a trilocular capsule.Thus I have increased this fine Genus to $10 \mathrm{sp}$. and they may be more: to deem them mere varieties would be preposterous; but they may be specific deviations of a single original type. These plants were called Wampi by the Indians and the seeds eaten by them. They are now called Pickerelweed in the Northern States. The articulated stem at the leaf aud spatha is similar to that of those Amaryllis lately divided on that score.

426. CLIN'TONIA Raf. 181\%,1819. Anals 1820 Med. fl, 1830,atl. j. 1832, adopted by Beck 1833; not the Clintonia of Lindley 1829 which is $\mathrm{my}$ Gynampsis 1833-Beautiful distinet G. of mine indicated since 1817 in my reviews, described in 1819 in Silliman's Journal and 50 N. G. of plants: it is formed by the plants blended in Dracena borealis and since united to Convallaria and Smilacina! that have quite a peculiar habit and a bilocular berry, striking character common with Styrandra, but this has only 
4 stamens. See my med. flora article Sigillaria, and my flora tellur. for the Genera blended in Convallaria and Dracena. The characters of Chintonia are perigone corolliform 6parted campan. deciduous, 6 stamens inserted at the base, filiform, anthers oblong, style compressed, stigma bilobe compressed. Berry bilocular, cells polysperm. Roots creeping perennial, stem scapose leafy at the base only, flowers terminal geminate or umbellate whitish, berries blue-they are rare plants of the Canada region and the highest Mountains, flowers vernal, called Cuscum by the Linapian tribes. Dedicated to my friend the worthy D. Clinton a worthy Philosopher, Naturalist and Botanist as eminent as Jefferson. Beck reduces the sp. to $\mathbf{C}$. borealis and multiflora which are each the type of a subgenus, but include several sp. and varieties, that $I$ have carefuly studied.

427. Subgenus Cuscumia Raf. (or PodaniSIA if too barbarous) flowers 2 to 5 no bracts, sepals oblong or lanceolate opening like a bell, style equal or longer than stamens, stigma bilobed. Only 2 or 3 leaves, flowers ochroleucous, peduncles unequal.

428. Subgenus Onyxula Raf. flowers umbellate 7 to 15 with one or more minute bracts, sepals unguiculate or base attenuated, claws erect, limb oboval spreadihg or rotate, style shorter than stamens, stigma notched. Several leaves 4 to 7 subradical, flowers white, peduncles eqaal.

429. Clintonia (Cusc) biflora Raf. Three similar leaves elliptic cuneate acuminate ciliate, scape smooth elongate biflore, peduncles erect unequal, sepals lanceolate obtuse berries rounded-Apalachian Mts. or Southern Alle- 
ghanies, flowers medial whitish, style longer than stamens, stigma quite bilobe, leaves 5 or 6 inches long, scape 7 to 8.

430. $C l$. biflora Var. humilis differs by smaller leaves more cuneate, 3 to 4 inches long, scape 4 to 5 .

431. CL. (Cusc) triflora Raf. Leaves 3 dissimilar unequal, 2 elliptical, 1 lanceol. smaller, all ciliate acute, scape pubescent elongate triflore, peduncles unequal pubescent erect, sepals oblong obtuse berries globular-Mts. Alleghanies on rocks in summits of ridges, humble, leaves 4 to 5 inches long, scape 5 to 6 , flowers pale, commonly 2 peduncles opposite shorter incurved with nodding flowers, one erect longer. Var. triaens, the peduncles subequal like a trident.

432. Cl. (Cusc) angustifolia Raf. subcaulescent, leaves $\mathbf{3}$ similar alternate elongate narrow cuneate lanceol. acumin. ciliate, scape smooth subequal to leaves,commonly 5flore, peduncles unequal flexuose, sepals oblong obtuse, berries globular-summits of Central and Northern Alleghanies, larger plant nearly pedal, with narrow leaves 8 to 10 inches long and only one wide, flowers smaller than in the two last, but berries larger.

433. Cl. (Cusc) ralcata Raf. Leaves 3 dissimilar, 2 broad lanceol. acum. one narrow lanceol acute falcate, all smooth like scape elongate 3-4flore, peduncles subequal erect, berries oblong - found only once in fruit on the summit of the Oquago Mts. leaves equal in length about 6 inches, scape 9 inches, peduncles-elongate uncial fastigiate.

434. Cl. falcata Var.tridens. Raf. 2 leaves radical elliptical lanceol. one on the stem quite 
narrow falcate, scape triflore, peduncles pubescent shaped like a trident. Also on the Oquago mits.

435. CL. (Cusc) pon.tyisia Raf. annals 118. Leaves 3 similar elliptical acute ciliate, scape pubescent double of leaves, umbel 4-5flore pubescent, peduncles very unequal mostly incurved, flowers creet, sepals lanceolate acute, berries globular. - summit of Backbone mts. of Alleghanies, leaves 4 inches long, scape 8 inches, flowers large whitish.

436. CL. (Cusc) nutans Raf. 1819. borealis Beck 1833. Convallaria and Smilacina borealis of some botanists P. N. E. not in Mx. nor Torrey. Subcaulescent, leaves 3 to 4 similar obovate or broadly elliptical acuminate ciliate, scape longer 5-6flore smooth, peduncles unequal nodding, sepals oblong obtuse, style shorter, berries oblong-Kiskanom and Oquago mts. Alleghanies of Pennsylv. and the most common kind, yet not seen or overlooked by some botanists, quite distinct from the last by larger flowers not white but yellowish; and oblong berries as in Cl. falcata, 8 to 10 inches high. A fine specimen has 3 leaves and 6 flowers.

437. Cl. nutans Var. bifolia Raf. differs by 2 leaves, umbel 4 flore, peduncles erect subequal. Mt. Pocono of Alleghanies.

438. Cl. nutans var. flexipes Raf. differ leaves twin long elliptic acute, scape flexuolate elongate 3 flore, peduncles pubescent unequal flexuose, berries ovate oblong. Mts. Tuscorora and Mahantango of Alleghanies, scape pedal, flowers pale. Perhaps rather a var. of $\mathbf{C l}$. triflora.

439. Cl. (Cusc) ophioglossoides Raf. cau- 
lescent, only one radical leaf obovate acute ciliate, a stem leaf smaller oblong lanceol. acute, scape pubescent 4 flore, peduncles pubescent unequal, 2 shorter incurved, 2 longer erect, berries globular-Sent me from Michigan, semipedal, leaves 3 or 4 inches. Is it a var. or deviation of $\mathrm{Cl}$. podanisia?

440. Cl. (Cusc) latifolia Raf. Leaves 4 similar short broad subovate abruptly acum. ciliate, scape elongate 4 flore, smooth, pedurcles erect subequal, sepals oblong, obtuse, style elongate, berries oblong-Mts. Taconick and hills of New England, probably in Canada also, scape pedal, leaves 4 to 6 inches, flowers ochroleucous larger even than in $\mathrm{Cl}$. nutans, with style longer than flower, a large bilobe stigma, leaves really broadly ovail.

441. Cl. (Cusc) biumbela Raf. Leaves 3-4 similar elliptical ciliate, scape with 2 umbels the lateral 2-3flore, the terminal 4flore, peduncles smooth unequal, petals lanceolate obtuse, berries globular and oboval-Mts. Alleghany, pedal, fiuits singular unequal in size and shape.

442. Cl. biumbella Var. aitoni Raf. Cl. aitoni Raf. atl. J. p. 120. Dracena borealis Ait. Andr. repos. t. 206. Leaves undulate not ciliate? scape flexuose, 2 umbels 3 -4flore noddirg berries globular-from Canada and Hudson Bay, cultivated in England. Is it a peculiar sp. to be called $\boldsymbol{C l}$. undulata or Aitoni? the figure in Andrews represents the stigma as oblique truncate dilatate emarginate.

443. Cuin'ronia (Onyxula) parviflora Raf. annals 117. Leaves 5-6 elliptical or lanceolate acuminate, margin and nerves ciliate, scape equal to leaves pubescent, umbel 5-6flore bract obsolete, peduncles crect equal, sepals ungui- 
culate spatulate obtuse, berries globular.-Summit of the Central Alleghanies of Maryland, only found once in $\mathbf{1 8 1 8}$ on a single rock, small plant 4 or 5 inches high, flowers snowy white not spotted very small, limb of sepals rotate obovate. Certainly distinct from all the next.

444. Chintonia (Onyx.) odorata Raf. Dracena borealis Big. Conval. umbel. Mx. Eat. Smilacina do. P. N. E. T. Leaves oblong elliptical with an obtuse point, ciliate, but nerves smooth, scape elongate pubescent above, umbel multiflore 9-15flore, a short oblong bract, peduncles subequal, sepals unguiculate spatulate undulate ovatoblong obtuse, berries globularMountain bogs from Canada to Carolina says Beck, never met by me, my specimen is from Collins H. and has only 9 flowers, they are white and small but larger than the last, Michaux says they are odorous and have some red dots; no other kind is odorous. 'This is the only sp. known or acknowledged by Torrey and others, who have never travelled in the Mts. in the vernal season.

445. Cl. odorata var. decantha R. my Cl. decantha of atl. J. only differ by $\mathbf{1 0}$ flowers petals lanceolate (acute?) 4 leaves oblong acute. -In the Mts. of Virginia, seen drv.

446. Cl. odorata var. multijiora Raf. my Cl. multifl. of atl. $\mathbf{J}$, only differs by leaves large elliptical acute, scape pedal smooth, umbel of 12 to 15 flowers, white sepals obovate acute? - Seen in the herb. of Torrey as Conval. umbellata, from Canada, is it odorous? is it rather a var. of the next sp?

447. Clintonia (Onyx) fulva Raf. Leaves ample cuneate elliptical acumin. glaucous ciliate, nerves smooth, soape subequal sulcate cos- 
tate, pubescent above, umbel multiflore (16) peduncles unequal some forked fulvous villose, bracts obsolete sepals unguiculate ovatoblong acute, berries globular-found in Collins herb. as Conv, umbel. certainly not the same as the last, distinct by leaves, scape sulcate, larger flowers nearly as large as in Cl. podanisia, apparently fulvous or nankin color, leaves 8 inches long.

448. Clintonia (Onyx) glomerata Raf. Leaves 3-4 similar obovate elliptical obtuse ciliate, scape equal villose above, umbel multiflore, bract lanceolate elongate, flowers subsessile glomerate pubescent-Apalachian and Wasioto Mts. my specimens have the flowers not quite unfolded with a longer bract. Only 3 to 4 inches high, quite distinct by obtuse leaves and sessile hairy flowers.- Thus I have noticed about $20 \mathrm{sp}$. or striking var. of this pretty $\mathbf{G}$. I had only 7 in my remarks of 1832 . None of our Botanists know them, because rare vernal and alpine; or when seen mistaken for a single kind! yet I venture to say they all originate from 4 or 5 original types.

449. ETHEOSANTHES Raf. Neog. 42. fl. tell. 27. Near Tradescantia, difference Calix and Corolla unequal, one petal larger concave,stamens 6 unequal curved villose, 3 longer. Stem ramose, flowers racemose without spathas-a fine Genus described by me as early as 1825 , seen alive since 1820 in the gardens of Kentucky where received from Louisiana. I collected $\mathbf{5 0}$ specimens and have sent it to all my correspondents. I sometimes spelt the name Eothinanthes, both mean evanescent flowers.

450. Etheosantues cimiata Raf. stem erect 
dichotome, leaves ovate acute undulate ciliate, flowers racemose secund.-Texas and Louisiana, fine plant 3 feet high, leaves 2 or 3 inches long, flowers large blue, the $\mathbf{3}$ petals are quite evanescent, lasting only one hour expanảed towards noon, but the calix is persistent as in Tradescantia. See in fl. tellur. my reform of the Genera blended in Tradescantia ; without attempting to give a complete Monograph of our real Tradescantias (which now amount to about 15 species:) I shall here chiefly enumerate my new species and varieties.

451. Tradescantia Virginica $L$. this well known linnean sp. may be known by the lanceolate smooth leaves, long foliose involucre of multiflore umbels and villose calix; but so many sp. and var. are blended with it in gardens and herbals that it is needful to attend to many other differences, as will be seen below in my New sp.

452. Trad. Virginica Var. alba. Hooker b. $m$. 3501. this white flower variety is not my $\mathbf{T r}$, ohiensis.

453. Trad. ohiensis Raf. precis 146. Leaves flat linear acute smooth, umbel multifore, involucre longer than flowers, calix smooth.-In Ohio, flowers white, described in 1814 from a specimen of Dencke given me by Vanvleck, but I have not met it in Ohio, and it may be a var. of my Tr. levignta.

454. Trad. virginica Var. purpurea Raf. differ by leaves narrow lanceolate, 6 to $10 \mathrm{in-}$ ches long, umbel pauciflore 5-6fl. petals purple - seen only in gardens, not met spontaneous, yet probably a peculiar sp. Tr. purpurea.

455. Trod. virgin var. barbata Raf. differ by umbel. pauciflore 5-6fl. calix smooth except. 
a tuft of hairs at the tip-very different fiom my $T r$. barbata, only seen in gardens, leaves broad, involucres large long not bearded.

456. Trad. virgin, var. ramosa Raf. 3 to 4 feet high much branched, with large leaves and flowers. Another garden variety.

457. Trad. virgin. var. angustifolia Raf. Probably the real type of Virginica, since the most fiequently found wild by me on the $R$. Schuylkill, the hills of Maryland and Virginia. Stem simple pedal, leaves linear lanceolate very long, longer than stem, 6 to 9 inches, flat and margin ciliate at the base. Umbel multiflore 6-12flowers nodding, 2 foliose involucre flat subequal 3 to 4 inches long, peduncles and calix pilose, flowers rather small, vernal in May. Roots perennial fasciculate. If a peculiar sp. it may be called Tr. ciliata.

458. Trad. Levigata Raf. Quite smooth ramose, leaves narrow lanceolate elongate flat glaucescent, base dilatate undulate and vaginate, umbels terminal and axillary multiflore glomerate, involucres foliose lanceol. unequal, calix smooth glaucous or incarnate-in the Apalachian Mts. of Virginia and Carolina, introduced in our gardens, 2 feet high, very pretty, flowers blue. A var. incarnata has flesh colored flowers.

459. Trad. Barbata Rrf. Smooth simple, leaves linear lanceol. canaliculate pale elongate erect; umbel pauciflore involucre subunifoliate very short, peduncles unequal erect; calix bearded at the tip as well as the involucresIllinois and West Kentucky, pedal, flowers blue 4 to 5 . Several varieties.

460. Trad. barbata var. pumila Raf. diff. semipedal, invol. bifoliate base swelled. Kentucky. 
461. Trad. barbata var. trachiloma Raf. Diff. Leaves and invol. rough or subciliolate on the margins, two invol. very unequal. Kentucky.

462. Trad. canaliculata Raf. atl. J.p. 150. Quite smooth simple slender, leaves slender linear narrow canaliculate, falcate umbel pauciflore, invol. short flat very unequal, flowers smooth nodding.-In Kentucky and Missouri; estival blue flowers, stem pedal, different from $\mathrm{Tr}$. levigata by narrow hollow falcate leaves few flowers \&c, described since 1832 in Atlantic Journal.

463. Trad. rupestris Raf. atl. J. 150. Simple smooth, leaves elongate narrow canaliculate, umbel multiflore, invol. foliose divaricate very long, peduncles pilose-Cliffs of Ohio and Wabash $\mathbf{R}$. it has the leaves like the last and flowers like 45\%. Estival pedal.

464. Trad. Brevicaulis Raf. atl. J. 150. Stem simple very short flexuose, leaves much longer narrow nearly flat carinate, sheaths tubular ciliate, umbel pauciflore, invol. similar to leaves, peduncles and calix very pilose-Illinois and Kentucky, stem 5 to $\mathbf{6}$ inches high, flowers blue and small vernal.

465. Trad. pumla Raf. Nearly stemless quite pilose, scape 1-2inches strait, leaves few lanceolate ciliate, umbel multifl. 8-12fl. involucres foliose subequal larger and broader than leaves, pilose, peduncles filiform unequal pilose, calix pilose-a very fine singular sp. found near the Kentucky $\mathbf{R}$. in abundance in a single spot in 1821. Quite dwarf and with long soft hairs, sometimes quite scapose, leaves longer than stem radical commonly 2 with membran. sheaths. Flowers quite large blue vernal. 
466. Trad. pilosa Lehman 182\%. Hook. b. m. 3291. Stem flexuose nodose villose above, leaves broadly lanceol. undulate pilose, umbels terminal multiflore, involucres foliose, peduncles and calix villose.-Louisiana and Florida.

467. Trad. axillairis Raf. subaspera? Lodiges cab. flexuosa Raf. atl. J. 150. Stem ramose sulcate often flexuose, leaves broad lanceolate flat pubescent pale beneath, margin rough, umbels axillary subsessile, involucres lanceol. short peduncles and calix villose.-In Central and West Kentucky, estival, flowers dark blue handsome, stem 2 or 3 feet high, leaves one inch broad 4 to 6 long, rather rigid. Var. flexuosa, stem dichotome zigzag. 2 subaspera leaves roughly pubescent.

468. Trad. discolor Raf. virginica var. pilosa Lindl. bot. reg. 1055? Stem strait pilose simple. leaves lanceolate divaricate ciliate,glaucous and pilose beneath, umbel terminal multiflore lax, involucres foliose divergent, peduncles short nodding pilose like the calix-In Florida and Alabama, stem pedal and bipedal leaves like the last, but thin, smooth above, not rigid nor rough. Var. ramosa, branched, leaves narrow lanceolate.

469. Trad. Reflexa Raf. Quite smooth, stem subramose slender purplish, leaves remote narrow lanceol. falcate flat, sheaths swelled, umbels multiflore glomerate, the rameal with unifoliate involucre, the terminal with 2 foliose falcate reflexed invol. peduncles often reflexed, calix ciliate at the end-Alabama, sent me as Tr. virginica! near to levigata and barbata, distinct by few leaves far apart 6 to 8 inches long only half inch broad, pale beneath, stem 1 or 2 
feet high, flowers small, umbels crowded 12 to 24 flowers.

470. Trad reflexa var. drepisia Raf. diff. umbels pauciflore 6-8f. 2 invol. quite equal fal cate. Alabama.

471. Trad. rosea Mx. Carolina to Louisiana, very distinct sp. by many short involucres, smooth graminiform leaves and rosate flowers.

472. Trad. rosea var, pauciflora Raf. Tr. graminifolia Raf. atl. J. 148. differs by few unequal flowers in the umbel. Florida and Alabama.

473. Trad. pivaricata Raf. atl. J. 148. Eeaves remote divaricate oblong lanceolate, umbels multiflore, invol. 2 subequal lanceol. divaricate, calix smooth.-In Florida, near the next, but quite smooth and umbels different. Seen in the herbal collected by Gates.

474. Trad. riparia Raf. stem simple, leaves oblong lanceolate flat abreviate smooth, base and sheaths ciliate, single terminal umbel 3-5 flore, involucre 2-3foliose subequal, peduncles short erect calix bearded-a very distinct and rare sp. only found once in 1818 , in the bed of Green R. in Kentucky near the mouth of it, and since received from Alabama; it has the habit of a Commelina, the stem only 6 to $10 \mathrm{in}$ ches high, leaves shorter than in any other kind 1 to 3 inches long, thin and smooth, invol. similar, flowers pale blue as in Commelina, estival, blossoming in August.

475. Dioscorea megaptera Raf. scandent, leaves alternate smooth cordate acuminate $\boldsymbol{\gamma}$ to 9 nerved, petiols elongate spikes axillary ramose lax, fruit large uncial fulvous rounded with 3 wide wings - in Kentucky, estival, near to $D$. villosa but smooth and fruit uncommonly 
large, emarginate at base, leaves pale beneath. This tropical Genus extending to N. America has there many more sp. only two were known, I shall add 6, they have all perennial thick roots called yams.

476. Dioscorea mexaphylla Raf. erect, leaves whorled by 6 on very long petiols, subcordate shortly acuminate smooth glaucous beneath with 11 fulvous nerves, spikes whorled ramose filiform, flowers often geminate-Apalachian Mts. of Virginia, stem rigid brown tripedal. Near to D. quaternata, first leaves opposite.

477. Dioscorea repanda Raf. stem flexuose scandent, leaves whorled by 4 below, alternate above, petiols equal to leaves filiform sulcate hairy above, leaves smooth ovate acuminate base reniform, margin repand, beneath glaucous 11 nerved, spikes short, capsules small fuscate-Virginia and Alabama in hills, leaves large truiy repand hardly cordate, apex falcate acuminate.

478. Dioscorea longifolia Raf. scandent, leaves ovatoblong base deeply cordate, lobes elongate proximate, apex acuminate, smooth concolor 5nerved, lateral forked-sent me from Alabama without flowers, leaves 6 inches long 3 broad.

479. Dioscorea sativa L. cult. in Florida, and perhaps wild also.

480. Dioscorea bulbifera L. 'The sp. was found at Mobile by Bartram (trav. p. 439) cultivated 60 years ago. It is remarkable by the large kidney bulbs 1 to 3 together axillary of leaves, tasting like the Yam root. My specimens have large cordate leaves 8 to 10 inches long, quite smooth acum. with 7 nerves lateral forked. 
481. PROVENZALIA Adanson 1763. Raf. fi. tel. 679. Calla L. and Authors which is root of Cala-dium. Cala-mus $\& \circ$.... Of this boreal G. only one sp. is admitted said to be common to both continents, but I shall now describe 4. C. ethiopica is a peculiar Genus, which I call Orosma ; $C$. oculta of Loureiro another that I call Spirospatira, see fl. tel. Calla ought to have been written Callaion! see Smith.

482. Provenzalia (or Callaion) palustris Raf. Leaves similar cordate subacuminate, scape equal to petiols, spatha ovate cuspidate -in boreal Europe and America, Canada, \&.c. Var. 1. parvifolia leaves uncial.

483. Provenzalia (or Callaion) heterophyLA Raf. Leaves dissimilar reniform or cordate acute, or rounded cordate obtuse, scape equal to petiols, spatha elliptic cuspidate-Hudson bay and Sibiria. probably also Origon, rhizome or radicant stem articulated with fibres, leaves on long petiols unequal in size and shapes from 1 to 3 inches long or broad.

484. Provenz. (or Callaion) brevis Raf. Leaves ovate base subcordate subobliqual, apex acuminate, petiols very long, scape very short, spatha elliptic retuse cuspidate-Lakes and Swamps of the Alleghanies, Mt. Pocono and others. Roots fibrose matted very long, petiols thick 6 to 8 inches long, leaves 3 to 4 inches long, scape about 3 inches high.

485. Provenz. (or Callaion) bispatha Raf. Leaves ovate base cordate end obtuse or hardly acute, scape equal to petiols, spatha double large ovate acuminate not cuspidate, divaricate-from Origon collected by Walton, petiols and scapes thick: flowers very peculiar by the double divergent spathas (anomaly in the family of Aroides) foliaceous 2 or 3 inches long 
base amplexic. subalternate, spadix large elliptic, leaves 4 inches long, 3 broad. 'This shall form my subg. Callaion.

486. 'Typia crassa Raf. atl. J.p. 148. latifolia of Amer. bot. not L. stem humble foliose, leaves equal to stem, flat above, convex beneath at the base and not vaginate, end obtuse, spikes united and thick subequal, a bract between them ovate lanceol. membranaceousCanada to Maryland and Missouri. Stem only 3 to 4 feet high, spikes 4 to 6 inches long, one inch thick, lower brown very dense, leaves half inch brnad. In marshes as all the sp.

487. Typha elation Raf. atl. J. p. 148. latifolia Elliot and Southern botanists not L. stem gigantic, leaves shorter broad flat base vaginate, end acute, spikes confluent terete without spatha-Carolina to Kentucky, 8 to 10 feet high, stem round solid and smooth, leaves one inch broad. These 2 sp. are certainly different from the latifolia of Europe.

488. Typira spiralis Raf. atl. J. p. 148, iatifolia Sw. Lunan \&c. Leaves spiraly contorted, ensiform and vaginate at the base, end flat thick obtuse, spikes annexed each with a spatha-Florida, Cuba and Jamaica, mistaken alsu there for the latifolia, diferent from ' $T$. domingensis.

489. 'Typra gracilis Raf. angustifolia of Amer. bot. not L. stem slender, leaves equal narrow flat glaucous acute, beneath hardly convex and striated, spikes subequal slender widely divided without spathas-New Jersey to Virginia in marshes and near streams, 4 to 6 inches long, divided by a bare space of 2 or: 3 inches.

490. Typha angustifolia L. f.c. My specimens of this European sp. differ from the last 
by very long leaves 3 or 4 feet long, thus longer than stem less giaucous, same breadth but concave or canaliculate above, beneath quite convex and subangular, spikes unequal, lower or female 8 or 9 inches long, upper or male only 4 or 5 inches separated only by a space of one inch.

There is another undescribed sp. in Origon, and several in Asia, Australia, \&c, besides the T. domingensis, media and minor, all different from ours.

491. Iris floridana Raf. nearly stemless glaucous, leaves graminiform carinate trinerve not gladiate, scape uniflore shorter than leaves, petals spatulate obtuse smooth, 3 patent larger and 3 reflexed-Florida and Alabama, small 6 inches high, scape 4 inches, stigmas yellow pandurate obtuse. A striking species with small white flowers, ovary filiform striate, bract subulate.

492. Iris biflora (or virgata) Raf. stem slender virgate bisulcate biflore, leaves gladiate narrow graminiform nervose, striate, 2 spathas membran. lanceol. striate peduncles filiform, petals narrow beardless unguiculate below, tube very short.-Cheroki Mts. of Unaka, found by Mrs Gambold, Collins Herb. stem bipedal quite virgate few leaves, upper very short, spatha convolute acute subequal, ovary oblong, tricostate pinched above at the union with the corolla that is hardly tubular at base, flowers middle size, petals pale blue cuneate obtuse, the 3 inner petals not much shorter, stigmas or rather styles deeply divided to the base similar to petals but bifid at end. By this and corolla almost a subgenus to be called Stenilis. If biflora is preocupied it will be my I. virgata. 493. Iris convoluta Raf. stem slender,te- 
rete unifore, leaves slencer convolute striate mucronate, spatlis bivalve striate, peials beardless subequal oblon'g end ilabellate, stigmas lanceolate acute-Arkanzas and 'T'exas, another very peculiar sp. of this fine genus, one or 2 feet high, leaves long but shorter than stem, spatha convolute elongate inclosing the long ovary, flower large versicolor, petals fulvous edged with white, large end rounded tinged with blue like the stigmas.

494. Iris blevicaulis Raf. ff. lud. 55. stem angular pauciflore very short flexuose, leaves gladiate very long, terminal flowers geminate, spathas bivalve lanceol. equal to flowers, petals and stigmas beardless narrow subequal-Louisiana to West Kentucky, seen alive 1823, disc. by Robin long before, neglected as usual by our botanists. Stem only 6 to 10 inches 3-5 flore, leaves 12 to 18 inches, mostly radical, flowers very lerge vernal, white with blue tinges and base yellow, capsules hexagone.

495. Iris glumacea Raf. stem angular fistular flexuose pauciflore, leaves shorter gladiate striate, flowers solitary and geminate, spathas 3-5valve glumaceous ovate, petals beardless spatulate spreading yellowish whiteGlades of Alleghany Mts. akin to last, yet very distinct by broad glumaceous spathas, 3 petals much sinaller, tube of corolla slender elongate.

496. Iris glumacea var. angustifulia Raf. diff by stem not flexuose, leaves narrow gladiate, 2 or 3 flowers, spathas fulvous, petals pale yellow-in the glades of Illinois, if a peculiar sp. it may be called 1. pallens.

497. Iris Aurea Raf. atl. J. p. 80. Stem strait biflore, leaves longer broadly gladiate, end acum. falcate, flowers geminate beardless, 3 petals obovate entire, 3 lanceolate undulate, 
stigmas dilatate notched-in the ponds of high Alleghanies, discovered by Mr. Carr on the Pocono MI. and brought by him to Bartrams garden, where seen alive and compared with $\boldsymbol{I}$. pseudacorus very akin, but with bifid toothed stigmas. 3 or 4 feet high, flowers small golden yellow, the 3 inner petals shorter than stigmas, equal to anthers,capsules oblong deeply sulcate.

498. Iris fulva Mg. cuprea $\mathbf{P}$. N. E. rubescens Raf. fl.lud, 56. This sp. of Louisiana is easily known by its flowers of a coppery or brick red color. I have seen it alive in gardens since 1817 and ascertained that my I. rubescens was only a var. of it with leaves rather longer, and flowers darker brick red. Vernal.

499. Iris lacustris Nut. Dwarfish creeping stemless uniflore, leaves longer glaucous narrow gladiate,spatha convolute lanceol. acum. shorter than tube, petals beardless obovate subequal 3 patent spotted, 3 erect, stigmas shorter bifid dentate-On Lake Erie \&c, disc. by Nuttal, found by me again 1825 and seen also in gardens, vernal in May. Scape only one inch high, flower 3 to 4 inches long, tube rather longer than sepals, flower with a faint iris smell, of a violaceous color with a large saffron spot on 3 petals and dark dots on the claws and base of sepals. Iueaves strait erect 6 to 10 inches long, often marginated with white. My description is original and made on the living plants.

500. Iris tripetala Walt. El. Hooker b. mag. 2886. tridentata Pursh. A fine rare sp. from Carolina and Florida, easily known by the narrow leaves and 3 inner sepals very short tridentate. Well described by Elliot and Hooker, my specimen is from Elliot; the flower appears blueish, the 3 large sepals unguiculate, end fabellate, the 3 smaller reflexed. 
Thus I have given here $10 \mathrm{sp}$. of Iris, either new or quite rare; this account doubles our knowledge of this Genus, of which we have now about $20 \mathrm{sp}$. I possess nearly all the others Iris cristata, verna, virginica (these 3 often blended like the 3 next) versicolor, prismatica, gracilis, hexagona, missurica, sibirica, tenax figured by Hooker 3343 and Lindley 1218. These two last are from Origon. I shall perhaps resume a monograph of this pretty genus.

\section{APPENDIX.}

My Genus Diplostelma 316 which Nuttal had wrongly reduced to Actinocarpus in Collins herb. (there is no such genus, he meant probably Actinospermum of Elliot) has been described by him under the name Chetanthera in his new plants 78, without any reference to former name! whence it escaped my notice; but he has only one sp. C $h$. asteroides (a bad name) which is my Dipl. pumila, the rays are violet and the blossoms are vernal. I have added 2 other sp. and my name is the best, although Nuttal's dates of 1834 , Chetanthera means bristly anthers, while this is not the case, he ought to have named it Chelopappus, but as the pappus is double and. different mine is the best and must be retained.

\section{INDEX OF GENERA.}

SUBGENERA and SYNONYMS of this NEOPHYTON. Synonyms are in Italics-References to the numbers.

Afzelia 392. Agalinis 371 to 385 . Alatipes 357. Aliseta 233.

Apentostera 409 to 411 , Arnica 236.

Asarum 221 to 224. Aureolaria 360 to 366 . Baptisia 321 to 341." Bellis 237 to 240. Brunella 256 to 265. Buchnera 266,267,298. Cacotanis 312. Calla 481. Calystegia 255.

Capsella 248 to 254. Chetanthera, Apx. Chlonanthes ? 220. Chelone Clintonia 426.

Clipteria 314. Comandra 269 to 273. Conradia 406.

Crotalaria 344 to $35 \%$. ( Cuscumia 427. Cytisus 343. Dasanthera 396-8 Dasistema 389 to 391. Desmodium 216. 
Dioscorea 475 to 480 . Paleista 309-11.

Diplostelma 316 to 319, Panctenis 367 to 370. Apx.

Drepilia 342.

Dracena 426.

Eaplosia 339 to 341. Eclipta 299 to 315.

Epatitis 205.

Erinus 387. 391.

Etheosanthes 449.

Eustachya 227.

Galeopsis 226.

Galinsoga 314.

Geranium 275-6.

Gerardia 358 to 388.

Hedyotis 225.

Hydrastis 274.

Iocaulon 345 to 357.

Iris 491 to 500 .

Isanthus 277-9.

Lasinia 328 to $\mathbf{3 3 5}$.

Laxanon 203 to 320.

Leptandra 227.

Lepteiris 412.

Lobelia 209 to 214.

Lophanthera 359.

Macranthera 406.

Menyanthes 218-19.

Myctanthes 228-30.

Nymphea 208.

Odoglossa 201.

Onyxula 427.

Otosma 481.

Ovostima 401.

Oxalis 246-7.

Pagesia 399, 400.

Parthenium 241 to 244, 280.

Pentoștemon 409 to 412.

Pericaulon 336 to 338.

Peritris 234.

Phryma 289 to 292.

Podalyria 321 to 341.

Pontederia 415 to 425,

Provenzalia 481 to 485 ,

Rafnia 336.

Ripasia 326.

Ropalon 207.

Russelia 403 to 405.

Schwalbea 414.

Seymeria 391 to 395 .

Smilacina 426 \&c.

Sophora 321 to 343.

Spirea 293-7.

Spirospatha 481.

Stenilis 492.

Thecanisia 293-7.

Thermopsis 343.

Thlaspi 248 \&.c.

Tomanthera 386-8.

Tomilix 408.

Toxopus 406.

Tradescantia 451 to 474.

Triosteum 281 to 288 .

Tropitoma 216.

Typha 486 to 490 .

Unisema 415 to 425 .

Urtica 245. 


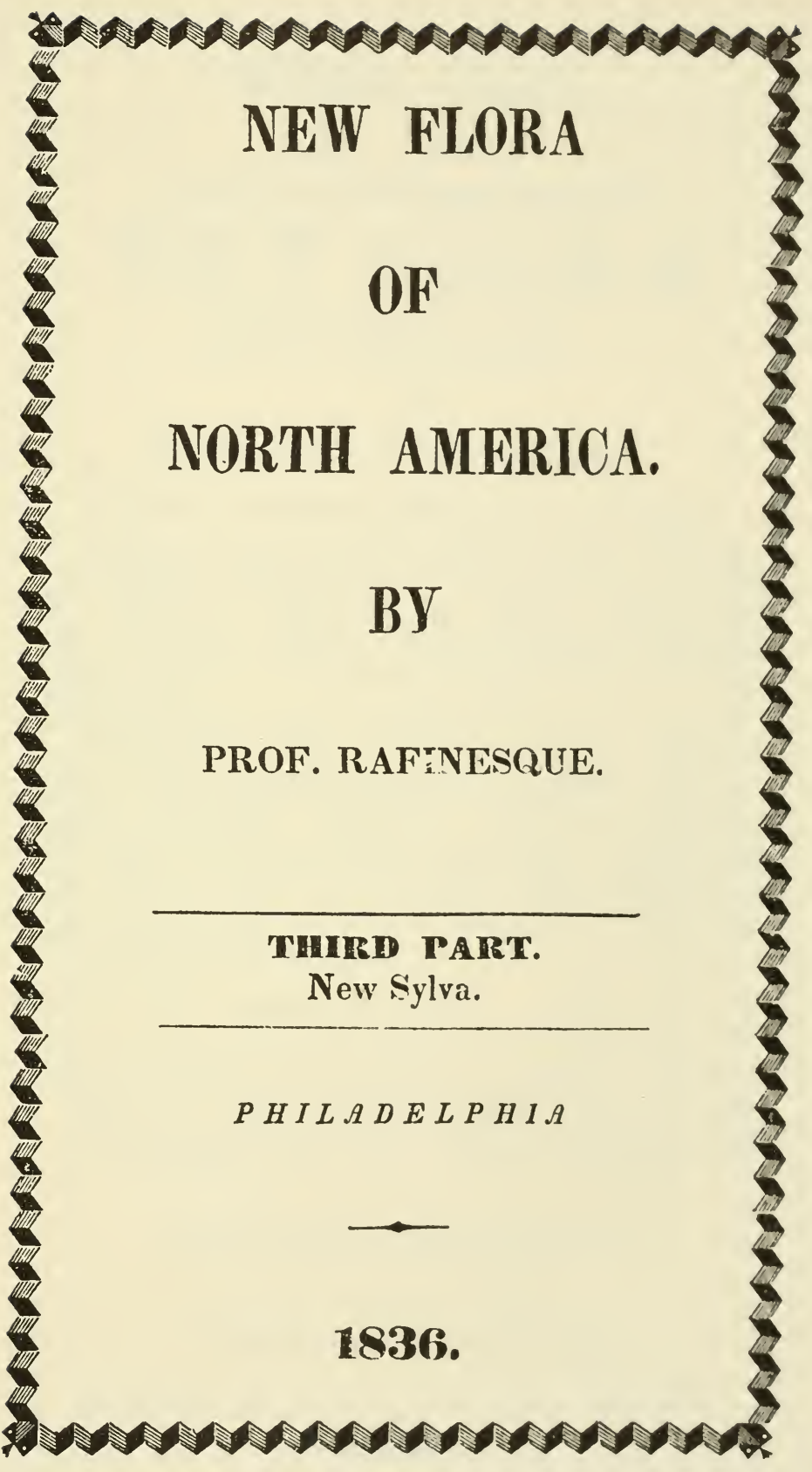





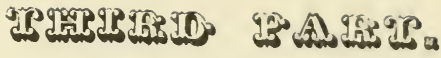

\section{NEW SYLVA.}

NEW FLORA AND BOTANY

$\mathrm{OF}$

\section{NORTH AMERICA.}

\section{BEING A SUPPLEMENTAL FLORA,}

To the various Floras and Botanical Works of Michaux, Muhlenberg, Pursh, Nuttal, Elliot, Torrey, Beck, Eaton, Bigelow, Barton, Robin, Hooker, Riddell, Darlington, Schweinit\% Gibbs, \&c.

Besides the great works of Linneus, Wildenow, Vahl, Vitman, Persoon, Lamark, Decandole, Sprengel, Jussieu, Adanson, Necker, Lindley, \&c. Containing nearly 500 additional or revised New Genera, and 1500 additional or corrected New Species, illustrated by figures in Autikon Botanikon.

BY C. S. RAFINESQUE, A. M.-PH. D.

Prof. of Botany, the historical and natural sciencesMember of many learned Societies of Paris, Vienna. Bonn, Bruxelles, Bordeaux, Zurich, Naples, \&c. and in Philadelphia, New York, Cincinati, Lexington, \&c.

The Floral weallh in this wide land concealed, Will be at last by learned care revealed.

P HILA DELP H IA:

PRINTED FOR THE AUTIOR AND PUBLISHEK. 



\section{NEW SYLVA OF NORTH AMERICA.}

Or the New and revised Trees, Shrubs and Vines observed, collected, and ascertained or corrected between 1802 and 1836 , by C. S. Rafinesque f.c $^{\circ}$ all figured in my AuTIKoN and Icones unless otherwise stated.

The Trees and Shrubs of North America have received very early attention, because they could usually be cultivated in Europe in the open grounds; several were introduced there long ago: Duhamel wrote chiefly upon them about one hundred years ago. Michaux and his son were sent to collect them for the public nurseries of France. Bartram and Marshall collected them here for English nurseries, and Marshall published in Philadelphia about 50 years ago, a general account of those known to him. He was followed and improved upon by Castiglione in Italy and Vangenheim in Germany, who both wrote on North American Trees and Shrubs, publishing figures of many. In England Miller, Trew, Catesby \&c, published also many figures of them in their works; but they were all exceeded by Michaux junior who after publishing the splendid Monograph of American Oaks of his father, printed both in French and English a very good special work on our Trees.

Watson, Jacquin and others have since published iconographical dendrologies, and several monographs have appeared; among which deserve peculiar notice, those of our Willows by Muhlenberg, Wildenow, Smith $\mathcal{f} \cdot c$, Pines and Firs by Lambert, our Ash trees by Bosc increased by him to 27 species, and my N.Am. Roses $\mathbf{1 8 2 0}$ increased to $\mathbf{2 5}$ species, with my 
N. A. Grape Vines 1830 , increased to 40 species, just as good and proper as the 40 willows and 36 oaks of our Authors.

All our botanical writers have of course attended more or less to our trees; but the only late special work upon them is an American Sylva with wood cuts published in 1832 by $D$. Browne in Boston, which however only contains 150 trees and shrubs, being a kind of abridgment of the larger work of Michaux junior, with all its faults and omissions, having forgotten like him, the Genera Sorbus, Aronia, and others, with many Cherry and Plumb trees, Ash trees, Willows and Poplars, foc. Besides all the large Shrubs and Vines, Palms and other monocotyle woody plants.

A true Sylva ought to include besides Trees, all the Shrubs that form the undergrowth of forests or fringe the banks of Rivers. In fact there is no actual difference between them in size; since all young trees are shrubs, and many shrubs become trees when old or in warmer climates. It is commonly stated that Trees have only one stem, while shrubs have several shoots; but many of our tress have several stems, while many shrubs assume the appearance of small trees by having only one. The distinction is therefore merely nominal, as between Rivers and Creeks, Lakes and Ponds, Mountains and Hills ....

Bushes or under shrubs unite likewise the shrubs to plants, the difference being the permanent perennial stem.

Twining or trailing shrubs are called Vines and creepers and belong also to the sylvan Flora; but there are Vines that are not woody, therefore perennial or annual Vines. 
The woody structure and permanence over ground during Winter under a state of hybernation, with evergreen leaves or sleeping buds, might most properly distinguish this series of Vegetation, and XYLoGY might be a better term to apply collectively to their knowledge than Dendrology and Thamnology.

Every one of the Botanical Regions of North America is distinguished by peculiar Trees, Shrubs and Vines; in fact they form the most prominent feature of each by their size and permanence. See my botanical regions.

Although so much attention appeared to be paid to these ornamental and useful productions, it was only lately that the multitude of our Pines, Oaks, Willows, Poplars, Ash trees, Hicories, Vines, Roses \&c have been ascertained: and it is a fact that many Genera are as yet little attended to or in utter confusion; many species and varieties being overlooked or blended as were formerly those of Oaks, Ash trees before Bosc \&c: my own sp. of Rosa and Vitis, well distinguished by me, are nevertheless invisible to some blind Botanists around me. I have been engaged for years in studying the fine Genus Prumus, now divided into Prunus, Cerasus, Padus, Orospodias \&c, and instead of 20 I know 30 or 40 species of it. I have discovered and possess a crowd of $\mathbf{N}$. sp. belonging to the Genera Prinos, 1lex, Spirea, Ceanothus, Rluamnus, Celtis, Pavia, Hydrangea, Viburnum, Caprifolium, Evonymus, Clematis \&c. I have even some new Genera of shrubs to describe in this Sylva.

The Genera Vaccinium and Andromeda, must be divided into many, and quite reformed, revised, corrected as to sections and species. 
Calycanthus, Hamamelis, Crategus, Viburnum \&c demand also a new revision. Abies and Aker have been partly corrected in the Lexicon of first part. Salix and Populus certainly require to have subgenera or better sections.

Much therefore remains to be done to detect, describe and name properly all our woody plants. I hope to do something towards it in this New Sylva. My reward will probably be as usual a denial of justice and neglect of my species, until they shall be introduced at great cost into the European Nurseries. It is said that a gardener that introduces a new T'ree or Shrub in England, often makes a great deal of money ky it ; but the learned Botanist who by 20 years of travels and exertions detects the locality, sends specimens or seeds, is unrewarded: nay it is expected that he should give away his specimens and seeds! If like myself he has discovered 100 or 200 new trees and shrubs, he is expected to give them all away for nothing! and not believed unless he does!

In the name of justice, pray why is a Botanist to be denied the privilege of Nurserymen and Sellers of plants? Michaux was paid for his collections and informations, Bose has been rewarded. Vanderschot was sent from Germany on purpose to collect seeds of trees by the Prince of Lichtenstein who has planted forests of American trees therc.

If I had been attended to and rewarded I could have introduced into our gardens, nurseries, and those of Europe, all my new Grape Vines and Roses, with 100 other fine trees and shrubs discovered by myself between 1802 and 1836. If they are yet unknown there or are very 
rare, it is because after paying myself all my expenses of travelling, collecting, preserving \&c I cannot afford to double them for others without reward.

Some of our trees have a wide geographical range, being found from Canada to Louisiana, such are Cornus florida, Cercis canadensis, many Oaks, Maples \&c; but others are confined to narrower limits, or even few localities. The Magnolia macrophyla, Virgilia or rather Cladrastis, Hamiltonia, Bigelowia, Franklinia, Planera \&c have each been met with only in 3 or 4 places as yet by botanists, altho' probably growing in others; but when found they are commonly abundant in the station. There are however solitary trees and shrubs that are never or but seldom found in groves or social groups; such are some Pavias, Calycanthus, Crategus, \&c, with many that I shall cnumerate in this Sylva.

The foliation, floration and semination of our woody plants, deserve to be better studied as . to periods and duration, in order to seek them at the proper times and places.

Their station is not always in Groves and. Forests; many are only found on the Sea Shores, these are called maritime-others in sands, or among rocks, in high Mountains, or along the banks of streams, or in marshes and swamps : they must be called arenarian, rupestral, montaneous, riparian and palustral.

As to foliation they must be divided into evergreens and deciduous. These last vary much in the time they put on and drop off their leaves. I have made 4 series of them in my dissertation on the foliation of our Trees, 1. Early leaves of long duration as Willows, Ma- 
ples, Larch \&c, 2. Early leaves of short duration as in Pavias, Prunus \&c. 3. Late leaves of long duration, as in Ash trees, Oaks, Chesnuts of c, 4. Late leaves of short duration, as in Catalpa, Liriodendron \&c ; but the exact times vary by 2 months from Canada to Florida, and in Florida many deciduous trees become nearly evergreens

The floration is either early or late vernal as in most species, before the leaves or with them Early or Late estival ; but fotw are serotine or autumnal as Hamamelis. The few hyemal trees may be deemed very early vernal. The duration of these flowers is seldom larger than half a lunation, some only last a week or a few days; whence they must be watched. Semination is more lasting, as seeds succeed the flowers, and are often a long while ripening; in some they even last on the trees and shrubs over the Winter.

The majority of our Northern trees and shrubs belong to the Amentaceous tribe, the Conifers, Rosacea and Senticose, Pomacea, Bicornes, Viburnides, Hederacea \&c. As we advance South; we meet a great variety of Rhamnides,Fraxinides, Magnolides, Ribesides, Akerides, Vitides, Ulmides, Cistides, Araliacea, Terebinthides, Lonicerides \&c, while when we reach Florida and 'Texas, several other natural families appear, the Rubiacea, Cactides, Laurinia, Eleagnides. with the palms and yucas of the Endogenous series. There also gradually appear the fruticose Malvacea, Leguminose, Saxifragides, Labiate, Hypericina \&o which are either unknown or rare towards the north or even the middle regrions of North America.

Few kinds of trees and shrubs are found in 
the Missourian regions, with its vast central plains; there they chiefly fringe the banks of streams, seldom forming groves and forests. 'This scanty dispersion prevails also more or less into the Origon Mts. and Shores, extending South to New Mexico, California, 'Texas and even Mexico; where the thick extensive Forests of the Alleghanian and Canadian regions are unknown. This straggling growth of 'I'rees prevails also to a certain extent from Louisiana to Florida where groves are intermixt with meadows, glades, sand flats, cane brakes, swamps \&c, and even in the Western States, on both sides of the River Olio, the trees are not so thick set, being far apart and with fewer shrubs for undergrowth.

Of the extensive tribes of Composites, Cruciferous, Euphorbides, Alsinides, Dianthicles, Geranides, \&c hardly any are shrubby in North America, while so many are such elsewhere. Our shrubby Vines belong chiefly to Sarmentacea, Rhamnides, Bignonides, Woodbines, Smilacea $\boldsymbol{g} \cdot \mathrm{c}$.

All the tribes of European and Siberian trees or shrubs are found also in North America, and nearly all their Genera likewise, except the Heaths, Daphnes, and a few others. But the American Sylva can boast of a greater number of species in all the Genera, with several peculiar tribes and many American Genera; such as Liriodendron, Magnolia, Asimina.Aralia, Catalpia, Hamamelis, Fothergilla, Gordonia, Dirca, Diervilla, Comptonia, Hicoria, Amorpha, Gleditsia, Robinia, Cladrastis, Chionanthus, Cephalanthus \&c.

It is very remarkable that nearly all the $\mathbf{A}$ merican trees, and shrubs except some boreal 
Willows, Brambles, Currants, Vacciniums ofe are specificaliy distinct from their congeneric kinds in Europe. The same fact appears in $\mathbf{N}$. W. America and Origon, where most are distinct from the Asiatic Species. In that region the prevailing Genera are Salix, Populus, Abies, Pinus, Ribes, Rubus, Vaccinium, Crategus, Cactus, Prunis, Quercus, Aker, Juniperus, Fraxinus \&c with but few peculiar Genera; but we lack as yet a proper account of all the sylvan productions of that region, and even many trees have not been described, much less the shrubs and vines, which are very abundant.

Trees and shrubs may be known by their foliage as well as flowers; in fact they are thus distinguished by Gardeners and the ignorant: their blooming is generally very short, but the seeds or fruits last longer, and are good indications of Genera. Even their bark and wood is of use to discriminate them. It is always important to notice if the leaves are opposite or alternate, distichal or spiral, simple or compound, entire or jagged \&c, since these peculiarities of frondose habit almost always indicate generic distinctions.

The North American Mountains cradles of our trees had been disguised by nicknames and mistaken heights, generally estimated too low. I shall restore and use throughout this work the original names. This I call the highest by the oldest name of Ourcos (which means hollow noisy ground or IIts. Oiigomenk in Linapi) those misnamed rocky Mts. shining Mts. and Chipewyan Mts. the snowy peaks of which rise 20 to 25 thousand feet.- Ihe Aprelachian Mts. are the Southeru Alleghanies, the highest be- 
ing the Unaka or Iron Mts. of North Carolina, their Western ridges are the Wasioto Mts. vulgarly Cumberland Mts : the lofty Kislicunom and Oquago Mts are the N. L. end of the Alleghanies nicknamed Catskill: the Mattaroun Mts. are those highlands broken through by the Hudson, and East becoming the T'acunic Mts. The Saranac Mts. are those at the head of the Hudson R. misnamed Peru Mits. 'The Wapanunk are the White Mts. highest of New England with naked or unwooded summits, a rarity in this continent.

\section{NEW SYLVA.}

501. XEROKALON Raf. calix adherent globular. disk hairy, crown 5parted, sepals unequal foliaceous persistent serrate. Petals 5 oboval concave subequal. Stamens 15 perigyne subequal erect, subulate, base nearly monadelphous, anthers bilocular elliptical. Ovary adherent, styles 5 filiform distinct, stigmas capitate truncate. Fruit umbilicate crowned a dry hard pormum, inside 5locular 5seeded, seeds cartilaginous oblong compressed nearly winged around. Shrub with alternate leaves and terminal flowers-This Genus has aftinities with Pyrus, Aronia, Mespilus, Crategus \&ce, being of same family : it differs from all by the unequal calix, 15 stamens, and dry fruit; the seeds are nearest Aromia, yet I apprehend it has been blended with Crategus, if already described elsewhere; but I could not find any sp. to agree. Discovered 1818, the name means dry apple. Only one species; but all the sn. of Crategus and Mespilus with serrate 
or laciniate calyx must be compared, and perhaps are akin, or form another Gienus near this: Cr. parvifolia is nearest, but is thorny with variable leaves, solitary fleshy fruits, with 5 or 6 laciniate sepals, reflexed oblong neither nervose nor acuminate. Cr. tomentosa of the South is a different sp. Cr. pyrifolic has corymbs and 3 styles only. I shall return on these in my monograph of the Pomaceous tribe.

502. X. овоvatum Raf. Autikon. Branches round inerme pnbescent above, leaves subsessile obovate unequally serrate, base entire, end acute, lucid above, puberulent beneath ; peduncles terminal pubescent commonly geminate, bracts sessile lanceolate dentate, sepals spreading ovate lanceolate acuminate nervose serrate puberulent, fruit globose semirugose-a small shrub hardly 2 feet high, flowers white blossoming in June, fruit redish rather large. Found on the summit of the Alleghany Mts. in Maryland only twice in June and October 1818. Seen no where else, probably growing also further South in the Apalachian Mts. of Virginia.

503. NESTRONIA Raf. Dioical. male fl. calix campanulate quadrifid, segments ovate obtuse spreading. Petals none. Stamens 4, inserted at the summit of the tube, opposite to segments but shorter, filaments linear flat, anthers oval bilocular dehiscence pubescent. Ovary totaly lacking. Fem. fl. . . Fruit monosperm Drupe? shrub with opposite leaves, and multiflore peduncles-singular new Genus, the name is derived from Knestron greek name of Daphne, since although the female plant is lacking, I have little doubt by the free calix that it belongs to the Daphnidia family and has 
a free one seeded berry. It will be with Dir$c a$ and Lagetta the third American Genus of it; but by the 4 stamens and opposite leaves, it is nearest to Struthiola, that differs however by calix filiform, 8glands and is not dioical. Two types if both are congeneric.

504. N. unbelula Raf. Autikon. Anonymos Boyken in Collins herb.-Branches hardly 4gone, leaves on short petiols, ovate rhomboidal acute at both ends, very entire and very smooth, thin membranaceous; peduncles axillary longer that petiols 3-5ftowered umbellate, partial equal to calix-discovered by Dr. Boyken in Greorgia, but not named, probably found also in Florida: a small shrub, branches brown leaves unequal very thin, one or two inches long, flowers small, probably somewhat yellowish, brownish when dry.

505. Nestronia? undulata Raf. Physic nut or Indian olive, Bartr. trav. p. 41. leaves broad lanceolate on short petiols: entire undulate smooth, drupes solitary pedunculate yellow olive like-I refer to this new Genus, a small shrub 2 or 3 feet high found 60 years ago by Bartram in the hills of Georgia, and omitted by all our Betanists. Bartram only saw the fiuit, and if I am right in my conjectures we have thus the fruit of Nestronia. Before obtaining $N$. umbellulu I had considered that it was a new Olea or Adelia of Michaux; but it agrees with none while it agrees much better with my NestroNIA, although still a peculiar species by narrower undulate leaves. The fruits are yellow like an olive on long slender erect peduncles, Bartram says it was used by the Indians as a charm to entice game. 'I'hese two shrubs may be easily distinguished at first sight from Nyssa 
and Hamiltonia by the opposite leaves. I suspect that the Rlammus? cuneatus of Hooker flora and Origon may be a third sp. having opposite leaves it can be no Rinamnus! Hooker did not even see the unfolded flowers. It might be called $N$. cuneata Raf. leaves petiolate cuneate entire, smooth above, pubescent beneath, branches rusty pubescent, fl. capitate axiliary peduncled bracteate.

206. Cenastrus acuminatus Raf. Autikon, an C. myrtifolius? L. ad Virg. not Jamaica! erect? branches subangular, leaves petiolate ovate or oblong, serrulate, base acute obliquate, end long acuminate falcate; flowers terminal racemose paniculate peduncles ramose-discovered in 1825 in the Apalachian Mis, of Virginia, where also Linneus indicates the locality of the C.myrtifolius; but this Jamaica plant of Sloane differs by ovate acute leaves not acuminate nor oblique. Both C. myrtifolius and bullatus are omitted or denyed by our compilers, but the last is now cultivated in Europe, and has entire oval leaves. Because Nuttal and Elliot have not yet found them, they are doubted; let them be sought where they grow, in the Unaka Mts. This is a tall weak shrub with thin smooth leaves larger than in $C$. scandens 3 to 5 inches long, the lower oval, the upper nearly lanceolate, flowers white size and form of $C$. scundens, aceme not simple but compound.

507. Amorpina punctita Raf. Autikon. Smooth, folioles elliptical obtuse, but cuspidate, punctate beneath, base petiolate with a subulate stipule; spikes terminal curved cylindrical-a fine shrub with puiple flowers, folioles small, spikes 3 or 4 inches long. Discovered by Bradbury in the upper Missouri. 
508. Sorbus ripairia Raf: Autikon. Branches rugose, folioles 9 to 15 oblong sessile, base oblique entire, end acute equaly mucronate serrate, odd leaf petiolate broader acuminate; corymb paniculate, berries pisiform globular. -A small tree 10 to 20 feet high, growing on the margins of Rivers, the Missouri, upper Mississippi, lower Ohio, Wabash, Illinois; but rare. 'The fruit is very small commonly of a saffron color with 3 seeds oval compressed inclosed in a tongh shell, and thus nearly a drupe sometimes only one seed by abortion. Near S. microcarpa, which however has folioles acum. unequaliy serrate, not obliquate, berries scarlet and larger. Here the folioles are 2 or 3 inches long, pale beneath, quite smooth, petiols compressed at the base. The genus SorBus must be preserved, alihough some writers wrongly unite it to Prists: it is known at first sight by the pinnate leaves, and the calix not persistent nor crowning the fruit. It would be better to unite to it all the tristyle sp. of Crategus than to abolish it.

509. TRILOPUS Hitchell, or HAMAMELIS Linneus, name posterior? 'This G. has puzzled the Botanists, Jussieu wrongly united it to Berberides. It has now be made the single type of the Hamaneribes ; but it so near to my Sclerantmoes, that it must probablybe united thereto as a subfamily. Only 3 species were known; besides the doubtful varieties of Walter; but I have observed 6 species, and therefore shall now give their Monograph. They may be called hycmal shrubs, since they blossom late in the antumn, after the leaves have begun to fall.

510. 'Tr. or H. virginica Raf. med, fl. tab. 
45. Leaves ovate and obovate obtuse repand, base obliquely cordate, smooth ; flowers sessile clustered by 3 to 5 , calix and fruit pubescentthe names of $\boldsymbol{T} r$. or $\boldsymbol{H}$. riparia or hyemalis, would have been better, since it only grows on the margins of streams from New England to Carolina. It is in bloom in December and January, even when the snow is on the ground, and the fruit is ripe in the spring. Branches punctate.

511. 'Tr. or H. nigra Raf. Autikon. Leaves ovate and obovate, acute, repand subsinuate, base oblique obtuse not cordate, smooth and coriaceous, brown or blackish above, rusty and lucid beneath, flowers and fruits solitary.-On the Mountains Alleghany of Pensylv. and Virginia, in dry hills, shrub 6 to 10 feet high, found in bloom in Obtober 1818. Var. Catesbiana figured by Catesby, leaves ovatoblong, quite acute, serrate repand, is it a sp?

512. Tr. or H. estivalis Raf. Autikon. Leaves obovate acute, repand erose, base obliqual obtuse not cordate, smooth thin and green on both sides, flowers geminate mostly axillary - small shrub 3 to 5 feet high growing in West Kentucky and probably further west also, near streams, but blossoming in July when in full leaf: these leaves are thin and not leathery as. in 510. Discovered in 1818 and 1823.

513. Tr. or H. Rotundifolia Raf. Autikon H. macrophyla P. E. Leaves orbicular or broadly ovate, base obliqual subcordate, repand sinuate obtuse, beneath reticulate roughly punctate, flowers subpedicellate 3-4-A large shrub, leaves only 3 to 4 inches long, not larger than in 510, 511, thus macrophyla was a bad name. First found in Alabana by Lyon, deem- 
ed doubtful by Elliot, but 1 have received specimens from Alabama and Georgia and describe it anew. The branches are round and smooth, not punctate nor geniculate as in 509, the fruit is rounded and pubescent, not sessile as in 509.

514. Tr. or H. Dentata Raf. Autikon. Leaves oboval acute with unequal acute teeth, base obliqual cordate, flowers sessile clustered -In Canada and New England, flowers polygamous and odorous as in most species, nearest to 509 , but leaves smaller while shrab larger often 10 to 12 feet high. Mistaken for H. Virginica by many or for a variety.

515. Tr. or H. Parvifolia Nut. R. aut. Leaves oblong obovate obtuse, undulate crenate, pubescent beneath, flowers agregate, calix oblong colored.-Mts. Alleghany of Pennsylvania yet very different from 210 , a small shrub 3 to 5 feet high with smaller leaves: yet deemed only a var. of 509 by Eaton, Beck, 'T. \&.c. They will probably deem all these $6 \mathrm{sp}$. as mere varieties also : yet they have good peculiar characters. As to those of Walter they must yet be described, since all the species are more or less polygamous and some even dioicaly so. See Fothergilla for other natural affinities.

\section{LONICERA or CAPRIFOLIUM.}

I shall begin now the account of my new or rare Loniceras or Honeysuckles by those of this Genus, their main type. They are all vernal, and blossom so early that the flowers are not easily seen in their native localities.

216. L. or C. rupestris Raf. Autikon. 
Smooth erect, leaves sessile obovate or rounded, glaucous cartilaginous retuse, floral connate cycloidal; flowers in whorls of 4 peduncles opposite biflore, berries oblong black-on the lime rocks of lientucky and Illinois, rare, seen only in. 3 localities, one at a Cave on the Elkhorn creck, 3 or 4 fect high, branches of a pale color. It blossoms in $A$ pril, so early that $I$ always missed to see the full bloom : near to $\boldsymbol{C}$. flarum but different.

517. L. elliptics Raf. Autikon. Climbing smooth, leaves all connate elliptic obtuse glaucous bencath subundulate not reticulate, floral connate in a single ellipse; flowers subgessile small purple, base gibbose-in the Apalachian Mts. of Virginia and Carolina, seen alive in gardens There are two varieties, 1 Macrophyla with long leaves 6 inches by 3 , the second Minor small leaves 2 inches by one. Does the doubtful undescribed $C$. rubrum of $\mathrm{ft}$. Louis. 248 belong here?

518. L. ovata Raf. Autikon. Climbing smooth, leaves all sessile ovate acute; flowers in axillary pedicelate corymbs, corols incarnate tube slender-on the same Mts. A palaches rare, only met once, leaves small, flowers middle size.

219. L. Reticulata Raf. Autikon. Erect smooth, branches angular, leaves all connate cycloidal neither acute nor retuse, beneath white and reticulate; flowers axillary and terminal berries red-shady hills of Ohio and Mts. Wasioto of East Kentucky, very small shrub only 2 or 3 feet high, leaves ample, the lower nearly elliptical, flowers not seen, near $\boldsymbol{C}$. gratum, but branches and leaves different.

520. L. eniexsis Raf. Autikon. Erect, 
branches brown, villose above, leaves all sessile smooth ovate mucronate, fuscate above, pale and reticulate beueath; bracts ovate villose, flowers villose outside-on the shores of Lake Erie, flowers large white and red: near to $\boldsymbol{L}$. hirsuta but this is quite hairy with obovate acum. leaves, the floral connate.

521. L. Acutirolia Raf. Autikon. Climbing flexuose smooth, leaves all connate subovate acute, terminal cycloidal biacute, glaucous beneath ; flowers axillary and terminal pedicelate corymbose, corol small gibbose incarnate-in the Mts. Alleghany, leaves ample 3 to 4 inches long. Near to $L$. parviflora, and $L$. elliptica 516, distinct from both by acute leaves and corymbose flowers.

522. L. Dentata Raf. Autikon. Erect smooth, leaves all connate oblong acute, remotely toothed, glaucous beneath, terminal united like a bell biacute; berries sessile ternate red at the bottom of the bell-near the last by acute leaves, yet different from all by toothed leaves. Flowers not seen. In the upper Alleghanies and Kiskatom Mts.

523. L. angustriolia Raf. or Kantemon do Raf. Autikon. Erect evergreen, branches round, leaves elliptic or cuneate all sessile, base acute, end obtuse, lucid above, glaucous and reticulate beneath : flowers naked verticillate, 4-6sessile, berries oval with a marginal crownin Florida, sent to me dry in fruit. Leaves 2 inches long, some very narrow, none comnate, the entire marginal calix appears to persist on the berries. Near to $\boldsymbol{L}$. or $\boldsymbol{K}$. ciliosum, but leaves neither ciliated nor ovate nor any connate.

This pretty Genus will thus be more than 
doubled by me; we had 7 sp. L. hirsuta, flava, parviflora, ciliosa, grata, douglasi; besides semporvirens, which is hardly of this Genus, and I have added $8 \mathrm{sp.}$ There are also peculiar sp. in Origon of which I will add one, thus $9 \mathrm{sp}$.

224. C. hispidulum Lindl. bot. reg. 1761. Hispid all over, stem weak prostrate, leaves petiolate cordate ovate obtuse glaucous beneath, upper sessile; umbel pedunc. stamens exerted-found by Douglass in N. W. America, f. red small scentless, umbels trifid, glomerules with 2 bracts.

525. DIS'TEGIA Raf. Lonicera and Xylosteon of Authors. Flowers geminate inclosed within 2 large bracts calix entire. Corolla urceolate, base saccate swelled, limb unequaly 5 fid. stam. 5 subequal style filiform declinate, stigma 2-3lobe, berry 2-3locular, at maturity subunilocular 1 or 2seeded. Habit of Xylosteum which differs by naked twin berries, corol not swelled, stigma entire \&c. This must at any rate be a subgenus of it. Notwithstanding the restoration of Caprifolium, Xylosteum, Diervilla \&c, these must again be revised. I think that Lonicera must have at last 4 subgenera, and besides $3 \mathbf{N}$. G. out of Xylosteon.

1. Caprifolium. Calix entire corolla bilabiate 1-4, tube terete.

2. Cypheoln Raf. diff. tube gibbose or swelled below, as in C. parviflorum, ellipticum, acutifolium, hispidulum of.c.

3. Kantemon Raf. cal. 5dentate, cor. subequal 5 fid tube fusiform or clavate. C. sempervirens, ciliosum, angustifolium \&c, which deserve to be a Genus? the stigma is capitate, berry 3 loc. cells 2 to 4 seeds. 
4. Eunemium Raf. cal. 5dent. cor. bilabiate 4-1, tube filiform very long, flowers geminate as in Xylosteon. 'This also might be a Genus. The type is C. longiflorum of Nipal, Lindl. b. reg. 1232, with leaves petiolate oblong lanceolate acute smooth, fl. axill. pedunc berries white. Lonicera glabrata belongs to it perhaps, although the tube is short.

Meantime my G. Distegra has 2 types, Lonicerce ledebouri? and involucrata, which is my.

526. Distegia nutans Raf. Xylosteon involucr. Richardson, Dec. Lonic. do Spreng. Lindl. b. reg. 1179. Leaves petiolate ovate oblong acute, pilose beneath, fl. axil, drooping -at Hudson bay and Boreal America, flowers small yellow.

527. Xylosteon puniceum Raf. Symphorea do. Loudon,Lonicera do Hooker bot. mag. 2469. Leaves cordate ovate petiolate acute concolor smooth; peduncles axillary biflore, berries distinct.-Canada, flowers red. Loudon made this a Symphoria, but it appears a Xylosteon.

528. Sympioria neterophyla $R$ af. leaves petiolate ovate and obovate, lobate or entire, obtuse and acute, upper elliptical, flowers glomerate terminal naked, berries white-from Missouri, seen alive in gardens, probably a singular deviation of $\boldsymbol{S}$. alba our Snowberry. $\boldsymbol{S}$. rubra is called Raccoon berry.

529. Dienvilla rongifolia Raf. Autikon. Leaves with short petiols, oblong ovate 4 to 6 inches long, acuminate serrate, base subcordate or obliqual, beneath glaucous reticulate peduncles $2-3$ flore-if this is only a variety of Diervilla canadensis, it is like the next, a wide deviation and incipient sp. A shrub 3 to 5 
feet high, with large leaves, and few small flowers, often axillary. On the Oquago Mts. of New York, north end of Alleghanies, it blossoms late in August.

530. Diervilla parvifolia Raf. stem or branches decumbent, leaves with short petiols, uncial, ovate acuminate scrrulate, lower rounded, fl. terminal subsessile 1 to 3 -in the Mts. Alleghany, leaves seldom over one inch long. The real D. candensis is a shrub of 5 to $\mathbf{1 0}$ feet high with ovate leaves, and trichotome corymbs of flowers. I noticed in this sp. or deviation a very long style with a large stigma like the head of an Amanita, convex above, conçave beneath.

531. Sapindus acuminata Raf. S. saponaria Elliot and North Am. bot. not Lin. and Antilles! Leaves with 8 or 9 pairs of folioles alternate lanceolate acuminate obliqual entire, petiols simple striate, calix with 2 larger sepals, 4 to 6 petals lanceolate base hairy -in Florida, Carolina, Alabama ofc, seen alive in Bartram's garden: wrongly mistaken for the Antillian sp. which is very different by winged petiol. A tree 20 to $\mathbf{3 0}$ feet high, pistil trigone, $\mathbf{3}$ united styles, 3 obtuse stigmas, 3 united capsules ventricose monosperm. 'The $S$. marginata of Wild. and Dec. found also in Florida and Georgia and the S. saponaria of Mx. differs by 6 pairs of folioles not acuminate, and half winged petiols as in real S. sciponaria. I have both our compilers call them both by that old name.

\section{Genus VISCUM.}

532. Viscum serotinum Raf. purpur. and verticil. of some bot. stem thick terete rugose 2-3chotome geniculate, leaves opposite evergreen subpetiolate, obovate obtuse hardly uninerve thick; flowers trifid 
monoical axillary spicate, male spikes terete verticillate triandrous shorter than leaves, female spikes glomerate, berries snowy white.Kentucky, Illinois, Missouri, \&c, parasitical shrub on trees, it blossoms late in the full and till December, flowers yellowish, almost similar to those of Cienus Osyris (see my dissertation, discovered 1819, indicated 18:0 as new. We have in $\mathbf{N}$. Amer. at least :3 sp. of Viscum with white berries, blended with $V$. album of Europe by Walter, Muhlenberg \&c, or with $\boldsymbol{V}$. flavens and verticillatum of South Amer. and Antilles by Pursh, Elliot \& c, but quite different from all these. This is the W estern sp. the berries are snowy white persistent in Winter, purplish when dry; thus perhaps V. purpureum of some botanists.

533. Viscun ochroledcum Raf. V. verticillatum Elliot Nut. 'Tor. not L. album Walt. not L. flavescens Pursh, Beck, not SwartzBranches terete opposite or quternate geniculate leaves subsessile obovate obtuse trinerve often quaternate, spikes nearly equal to leaves axillary often 4nate, flowers 3-4fid, 3-4andr. berries spiked yellowish white.-From New Jersey to Florida, parasitical, stem 1 or 2 feet, flowers very small vernal $A$ pril and May.

534. Viscum redcarpum Raf. fl. lud. 251. exclus. syn? stem articulate very branched, leaves opposite sessile oblong obtuse, flowers sessile axillary glomerate, glomerules pauciflore 2-3flore and 2-3berries white-in West Louisiana and Texas probably, distinct by the few flowers, probably enervate also.

535. Viscum oblongholium Raf. V.rubrum? auct. Branches rugose, leaves petiolate oblong or narrow elliptic, base acute, end obtuse, se- 
mitrinerve, rugose, spikes very short, berries solitary oblong (red?)-my specimen is from Florida, there also grow the V.rubrum of $\mathbf{L}$. and Catesby, stated to have lanceolate leaves; not seen by Elliot nor any of our Authors. Mine is now better described.

536. Viscum rugosum Raf. purpureum? of some Authors! Branches rugose, leaves petiolate oboval or broad elliptic obtuse trinerve rugose; spikes very short, berries spicate ternate or geminate oboval white, but red when dryin Delaware and Virginia, often on the Nyssa. The V. purpureum seen by few botanists is stated to have retuse avenous leaves, my specimens have 3 nerves reaching beyond the middle of the leaves.

Therefore it is evident that this Genus was quite obscure to our botanists, who had seen few species, and mistaken those seen. Neither Smith nor Elliot had seen the V.rubrum and purpureum, and only copiecl the errors of Linneus, who blends 2 or $\mathbf{3}$ species in $V$. purpureum, with purple and white berries, the sp of Plumier and the Antilles is probably the real species, yet Smith deems it the $\boldsymbol{V}$. buxifolium. The $2 \mathrm{sp}$. of the Bahama Islands figured by Catesby appear different from all ours, and are thus. 1. V. vulram of Cat. 2. t.81. leaves petiolate cuneate obtuse concave, berries red globular spiked verticillate. 2. V. purpureum. Cat. 2. t.95. leaves petiolate obovate obtuse enerve, berries purple turbinate racemose opposite, peduncles swelled.

'The blunders of Linneus on this Genus are egregious, see the criticism of Smith in Rees. His V.terrestre! is a Lysimachia! He has blended $2 \mathrm{sp}$. in V. verticillatum, the real sp. 
of Jamaica is aphyllous and perhaps not of this Genus; the other is V. buxifolium? of Smith with leaves ovate obtuse trinerve, and berries safron color. Yet our American Botanists persist to this day to call 2 or $\mathbf{3}$ of our species by that name! others unite our sp. to the V. flavens of Schwartz and Jamaica with ovate venose leaves and yellow berries! none of our sp. have ovate leaves, they are obovate! Such are the blunders of our best Botanists, and yet they pretend that our Botany is well known and our shrubs \&c properly named ... !

537. Diospyros ciliata Raf. Branches divaricate pubescent, leaves ovate and obovate or elliptic shortly acuminate, smooth above, pubescent beneath when young, margin ciliated, flowers axillary, solitary or geminate subsessile -Florida, seen alive in gardens, only a shrub 5 to 6 feet high, much spreading, branches terete ash color, leaves very unequal and various on the same branch, 1 to 3 inches long, smooth beneath when old, but always ciliate, petioles short, peduncles still shorter, calyx flat 4 lobed corolla ovate urceolate end 4lobe, lobes broad short, stamens 8 to 12 , anthers just protruding.

538. Cephalantius obtusifolia Raf. branches nearly hexagone, leaves ternate petiolate ovate elliptic obtuse not acuminate, base subobliquate, beneath smooth yellow glaucous,nerves subpubescent-sent me from Missouri, also seen in West Kentucky : differs from both $C$. pubescens and $\boldsymbol{C}$.acuminatus or occidentalis. The peduncles of heads has verticillated scales the corolla is slender equal to stamens, but the style is twice as long; flowers estival white and fragrant. It forms a shrub 5 to 6 feet high growing as the others near streams. 


\section{Genus CHRYSOBALANUS.}

This tropical Genus near to Prunus extends to Florida and we have several sp. only one was known, I shall describe 4.

539. Chrysob. oblongifolius Mx. Branchlets redish rugose, leaves subsessile oblong or subcuneate undulate, acute at both ends, lucid reticulate quite smooth, flowers terminal paniculate, dichotome and trichotome, calix white tomentose-in Florida, leaves 3 inches long, yellowish minutely reticulate on both sides, flowers small white, calix campanulate acute, stamens smooth. Not less than $3 \mathrm{sp}$. appear to have been blended by our Authors with this.

540. Chrysobalanus retusa Raf. Branches dark purple leaves subsessile entire, oblong base acute, end obtuse retuse emarginate, reticulate and quite smooth on both sides, above coppery lucid, beneath pale yellowish less lucid -found by Nuttal in Georgia and Alabama, not named but Genus ascertained (Collins herb.) It differs from Chr. oblongifolius by the retuse leaves of a metalic color above, 3 to 4 inches long, over one broad, but 2 other sp. have evidently been blended by Michaux and Nuttal.

541. Chrysobalanus incanus Raf. Var. of oblongif. Mx. leaves oblong oboval, white and wooly beneath-Florida. 'This must certainly be distinct from the 2 above, having no specimen I cannot describe it better.

542. Chrysobalatus (Spondolobus) PruniFourus Raf. Branches smooth, leaves petiolate ovate serrulate acute at both ends, base biglandular, both sides smooth not reticulate; flowers racemose, raceme pauciflore, drupes oblong-from Florida, in the Herbarium of 
Collins, mistaken for Bumelia! leaves small 1 inch long, quite similar to those of Prunus! racemes terminal 5-6flore, no bracts, pedicels long, calix broad flat campanulate 5dentate persistent, 5 petals obovate, stamens about 15 almost monadelphous at the base, filaments subulate, pistil on a thick thorus. oblong acute prominent, style lateral inçurved or flexuose, stigma obtuse. I have not seen the ripe fruit, but the young fruit is unlike any Prunus being oblong elongate acute like a pod one side strait. I have united this shrub with this Genus for the lateral style; but it deserves to be a peculiar subgenus by the calix, thorus, stamens \& c, a connecting link with Padus, I propose to call it Spondolobus Raf, meaning plumb-pod.

543. Chrysophylum lodovicianum Raf. fl. lud. 165. C. glabrum Robin not L. Spinose, leaves oblong lanceolate acute, silky beneath, flowers fasciculate axillary -in West Louisiana and Texas, only seen by Robin, mistaken for C. glabrum of Antilles, but this has smooth leaves. Omitted by our compilers and added here to recall it to their dull memory. A shrub 8 to 10 feet high, flowers small greenish, calyx 5parted, stigma sessile, berry globular, seeds compressed.

544. Chrysophylum Cainito var. potundifolium Raf. Leaves on short petiols rounded ovate acute at both ends, veins paralel, above shining lucid brown, beneath silky lucid rusty, flowers geminate, pedicels longer than flowers, fruit oboval rounded.- South Florida, and Florida Keys, A small tree, branches smooth ashy brown, leaves alternate coriaceous thick beautiful almost round very entire 2 or 3 inches long, nearly as broad, with a single thick 
nerve and many paralel veins. Flowers scattered, very small. My specimens labelled C. cainito appear to form another variety or deviation, perhaps it is a peculiar sp. as many have beon blended in $\mathrm{C}$. cainito with round and oval fruits.

\section{Genus BUMELIA,}

545. Bumelia unducata Raf. Branches inermous subopposite striate brown, leaves terminal alternate on long petiols, broad elliptic smooth minutely reticulate on both sides, base acute, end obtuse, margin undulate entire; flowers scattered fasciculate shorter than pedicels-a small tree from South Florida, labelled B. salicifolia in Collins Herbal, but quite distinct from the Bahama and Antillian sp. with narrow acuminate leaves. This has leaves 2 or 3 inches long and $1 \frac{1}{2}$ or 2 broad, quite obtuse and even somewhat retuse at the end, petiols 1 or $\boldsymbol{z}$ inches long: flowers not axillary scattered below the leaves 2 to 5 together, seldom solitary, calix smooth, sepals ovate acute, fruit oval style persistent.

546. Bumelia arachnoidea Raf. Arborescent, inermous? branchlets dark purple subrugose, leaves petiolate fasciculate cuneate oblong entire obtuse, smooth and reticulate above, beneath and petiols hairy arachnoidal, flowers on short pedicels fasciculate rufous hairy-in Arkanzas and Texas, large tree 40 to 50 feet high, leaves about 4 inches long and one broad, not lucid, dull on both sides, minutely netted nerves above, tomentose like spider webs beneath, very acute at base and very obtuse at end. Flowers very small and short, sepals of calix ovate obtuse. The $\boldsymbol{B}$. oblongifolia of Nuttal is akin hut differs by being a small tree 
15 to 20 feet high, leaves smooth (so says Nuttal although Eaton calls them hairy beneath) not so cuneate, branches thorny, flowers subsessile $\boldsymbol{f} \cdot \mathrm{c}$.

547. Bumela denticulata Raf. shrubby inermous? branchlets smooth rugose, leaves petiolate thin, broad oval elliptic, base acute, end subacuminate, margin remotely denticulate smooth on both sides, flowers solitary on long erect filiform pedicels, calix smooth, sepals round-from Florida, leaves 2 or 3 inches long with a few remote obtuse teeth on the sides, texture very thin, with veins rather than nerves slightly reticulate, pedicels over one inch long, stiff although filiform, flowers pretty large smooth. A very distinct species.

548. Bumelia? sernulata Raf. shrubby inermous, branchlets cinereous with white dots leaves subopposite petiolate smooth, obovate elliptical acute at both ends serrulate glaucescent beneath minutely veined reticulate with some scattered hairs-from Apalachian Mts. of Alabama small shrub, leaves small pale green, nearly glaucous beneath. Collected by Lyons, my specimen of Collins herbal has no flowers, but is labelled a new Bumelia. We have thus at least $10 \mathrm{sp}$. of this Genus with the 6 already known, and I have nearly all in my Herbarium ; but one requires correction, 2 or 3 sp. being perhaps blended under B. lanuginosa. My specimens collected by Ware in Florida have leaves elliptic obtuse or acute, hairy rusty beneath like the branches, and flowers thickly glomerate rufous hairy, is it a peeuliar sp. B. rufa? Raf. while the B. lanuginosa of Elliot and Authors, has leaves ovate lanceolate tomentose beneath, a third var. is 
the var. sericea or B. chrysophyloides of $\mathrm{fl}$. Louis. with similar leaves, but silky silvery and gilded beneath.

\section{Genus ANTHELIS.}

The Genus Crstus of Linneus was a medley of $\mathbf{1 5 0}$ heterogenous species, the modern botanists in restoring Helianthenu overlooked the perfect identity wiu. Heuia THus! both meaning Sun flower. To avoid this equivocal name I changed it in $\mathbf{1 8 1 2}$ in my Chloris Etnensis to Antuelis being a transposition (flower of the sun) this correction is indispensable. Of this Genus 5 sp. have been described as North American, and with 5 others from Mexico and Brazil form a peculiar group or subgenus quite American; Decandole calls this group Lecheoides owing to the similarity with Lechea, but if it is to become a Genus in future this derivation will not do. I am going to add several new sp. thereto and thus venture to call it Horantires flowers of an hour.

S. G. HOR AN'THES, sepals 5, external 2 narrow, internal 3 margin scariose, petals 5 yellow, stamens few 12 to 20 , stigma capitate large sessile or subsessile, capsule glabrous uniloc, 3 valve-small suffruticose plants, leaves opposite below, no stipules, flowers evanescent or petals fugacious. The $\boldsymbol{H}$.tripetala of Mexico is probably a Lechea! all our sp. are estival.

550 Anthelis (Horantues) podanisia Raf. erect pulverulent pubescent, stem virgate simple, leaves adpressed linear cuneate acute margin reflexed; flowers in axillary fascicles, or racemes, pedicels unequal, one terminal much longer, calix with 3 oval sepals, 2 linear equal, capsule oval equal to calix - on the Red River 
in Arkanzas Louisiana and 'Texas, stem pedal base suffruticose, leaves one inch long narrow, flowers small, calix cinercous pubescent.

551. Anthelis (Horanthes) arenaria Raf. many procumbent stems nearly smooth. leaves linear acute sometimes ciliate, pedicels axillary uniflore equal to leaves, 3 sepals membranaceous rufous smooth trinerve ovate acute, 2 linear subciliate-in sands of Pine barrens in South New Jersey and Florida, first discovered by $\mathrm{Kin}$ in 1801. Root large deep, many short diffuse stems, leaves small, flowers rather large. Monograph of CELTIS.

I mean to give a complete account of the N. American sp. of this Genus, increased to $\mathbf{1 5}$ kinds whereof 9 are trees and 6 are only shrubs. Linneus had only one, Lamark and others increased it to 3 or 4 , our latest compilers have only 4 sp. although I had added 3 others as early as 1817; but this Genus was little attended to, the species being very similar in habit have usualy been blended, even when seen, and often reduced by the leaves rather than flowers. They are known indiscriminetly by the vulgar names of Nettle tree, Beaver wood, Hackberry, Dogcherry, Cherry elm, Hoopash, \&c ; they bear vernal blossoms, and edible berries, leaves distichal alternate, the wood is hard and valuable; but they are rather uncommon in our forests except two kinds.

552. Celtis canina Raf. Am. M. M. 1817 Decads 6. Tree with smooth bark, branchlets smooth angular dotted, leaves ovate acuminate, unequaly uncinate serrate trinervate, base acute entire obliqual unequal, smooth on both sides.but wrinkled above, and axils of nerves pubescent beneath, fruit red globular 
solitary axillary, pedicels longer than petiols-a small tree 15 to 25 feet high, discovered 1816 in the State of New York, near the Mattawan Mts. it blossoms in April and May, the branches are spreading, covered with glandular dots. Torrey insisted that this was the C.occidentalis of Linneus, and yet believes it perhaps, therefore I will give the contrasted account of that sp. from my specimens, confirmed by the ample descriptions of Lamark, Smith and Elliot.

553. Cemtis occidentalis L. and Authors. C. virticifolia Raf, a better name-tree, bark rimose, branchlets pubescent angular not dotted, leaves ovate acuminate subequaly uncinate serrate trinervate, base acute entire obliqual unequal, young leaves villose, old leaves smooth even above, beneath quite pubescent, petiols pubescent, fruit purple globular solitary axillary, on pedicels subequal or shorter than petiols. -A large tree 30 to 70 feet high, spread thinly from New England to Carolina, flowering in March and April.-Thus it differs from the last by the bark branches, being larger, quitc pubescent, leaves also larger 3 to 5 inches long, fruit sweeter dark purple, Elliot says the sterile flowers are frequently ternate. The C. australis of Europe hardly differs except by rougher leaves and black fruit. The C.tenuifolia, pumila, alba \&c had all been deemed varieties of this by turns, and even Nuttal deems the $\boldsymbol{C}$.cordata as such! they might as well unite all the sp. of Asia and the Antilles into one!

554. Celtis alba Raf. fl. lud. 68. Var. integrifolia of Amer Authors, not the C. integrif. of Lamark, african sp.-Tree with smooth bark 
branchlets tomentose, smooth when older subangular dotted, leaves broadly lanceolate entire gradualy acute, base acute obliqual unequal trinervate, quite smooth on both sides, glaucous above, nerves reticulate beneath, fruits red small globular solitary or ternate, axillary on pedicels equal to petiols-a very distinct species, well described and named by me as early as 1817, neglected by our compilers; I have specimens collected in Arkanzas by Nuttal as a N. sp. or mistaken for the C. integrifolia of Senegal, which is totaly unlike having round and rough leaves \&c. It grows in Missouri, Arkanzas, Louisiana and Texas. Fine shady tree $\mathbf{4 0}$ feet high, bark whitish and scaly, cooling and anodyne. Leaves 2 or 3 inches long, one wide, of a whitish color, being glaucous above, while beneath less so, flowers small green; anthers opening as in Laurus says Robin, 2 hairy stigmas. Berries small red sweet. Blossoms in March.

555. Celtis fuscata. Raf. C. longifolia Raf. fl. tex. 9. Tree, branchlets smooth subangular verrucose, leaves smooth oblong lanceolate acuminate trinervate, fuscate base acute obliqual unequal, margin equaly serrate, beneath reticulate, pedicels equal to petiols-a small tree from Florida, Texas and also the Island of Cuba, where collected by Jalambic: quite distinct from the rough leaved sp. of the Antilles with broad or cordate leaves. Some of the leaves are broadly lanceolate, others quite narrow, commonly 2 inches long, their color is peculiar brownish, dark above, yellowish beneath. My specimens have no fruit. Found anonymous in Collins Herbarium. Var, texensis was my C. longifolia of 1833 only differ- 
ence leaves base truncate, roughish above.

556. Celtis salichiolia Raf. 'Tree, branchlets terete pilose with white dots, leayes oblong elongate narrow subacuminate sharply serrate, base obliqual acute trinervate, potiols and nerves pubescent-in Arkanzas and Louisiana, a small tree 20 feet high, leaves 2 to $\mathbf{4}$ inches long similar to some Willows but quite obliqual, very different from all the narrow leaved kinds, nearer to $\mathbf{C}$. occidentalis, but very different leaves. Is it a deviation of $\boldsymbol{C}$. fuscata? chief difference in terete pilose branches, nerves pubescent \&oc.

55\%. Celtis levigata W. Loud. Leaves unequaly cordate obliqual acuminate nearly entire, smooth on both sides-in Louisiana, small tree 20 feet high. I have not seen it, it was described in Wildenow Enumeration, I copy the notice from Loudun Cyclop. of plants. It appears different fiom all the cordate leaved kinds by the smooth leaves, and from my morifolia and patula by obliqual acuminate leaves.

558. Celtis morifolia Raf. C. cordata of some botanists?-Tree, branchlets redish hirsute angular or striate, leaves ovate oblong serrate acute or acuminate, base subcordate or truncate, slightly obliqual, scabrose above, beneath snooth pale reticulate, nerves yellow hirsute, petiols pubescent, pedicels longer than petiols - this is one of the $3 \mathrm{sp}$. blended and called Hackberry in the Western States. This is a tree 20 to $\mathbf{4 0}$ feet high, the branches have neither warts nor dots. Leaves 3 to 5 inches long, 1 or 2 wide, becoming quite smooth beneath when old, but always rough above hardly trinervate, but nerves regular and reticulate. Found in Illinois, Kentucky $\& \cdot c$, if I remember 
right the berries are blackish and ovate; but my specimens have no fruit. It has evidently been often mistaken for the next, which has shorter thicker leaves more acuminate, more cordate and more obliqual, quite pubescent beneath; it is nearer to C. micranthes of Antilles differing chiefly by larger serratures, pubescent branches, petiols ofc.

549. Celtis crassifolia Lamark and many Authors, C. cordata Persoon and others-tree, branches terete rough, leaves broadly ovate acuminate, unequaly serrate, base cordate obliqual, thick or subcoriaceous, rough on both sides, peduncles mostly biflore-a small tree 15 to 40 feet high, with large dark thick leaves quite rough, common from West Pennsylvania to Missouri and Kentucky, blossoms in May. Berrics black large sweet, called Hackberries or by corruption Hagberries, Hogberries.

560. Celtis reticulata Torrey, Eaton. Leaves broad cordate pubescent subcoriaceous, subentire, subobtuse, base unequal obliqual, papillose scabrose above, reticulate prominent nerves beneath, peduncles uniflore-in the Western parts of Missouri and Arkanzas extending probably to the Origon Mts. found by James deseribed by Torrey; I have not seen it and only copy his account to show that it differs no more from C. crassifotia than my C. morifolia, all 3 have cordate leaves and reticulate nerves, whence the name is not very proper. Is it a tree or a shrub? compare $\mathbf{C}$. patula.

561. Celtis maritima Raf. 1817. Decads 7. Shrubby, branchlets terete tortuose pubescent, leaves ovate acuminate trinerve rough on both sides with large equal serratures, base 
broad nearly cordate obliqual, petiols and nerves pubescent, pedicels subequal to petiols, a small crooked shrub $\mathbf{3}$ or $\mathbf{4}$ feet high growing on the downs of the sea shores from Long Island to Chesapeak. It blossoms in May, the branches are cinereous and slightly dotted, leaves small uncial. Very near to the next, but distinct by locality and acuminate rough leaves.

562. Celtis pumila Raf. C. occid var. pumila Mg. and some others, but not Pursh nor his copists.--Shrubby, procumbent, branchlets slender terete subtomentose, leaves thin ovate acute with large equal serratures, base truncate hardly obliqual trinervate both sides nearly smooth, petiols and nerves hardly pubescent -in the Alleghany Mts. from Pennsylvania to Virginia. A sinall low shrub only 2 feet high or long. Ieaves hardly over one inch, hardly acuminate rather acute, very thin and green, with very large teeth. This is marked in Collins Herb. as the real pumila var of Muhlenberg, but it appears that all our 6 shrubby sp. must have been blended under this name; I shall now distinguish them properly although the synonyms are difficult to fix, owing to all copying Pursh rather than describe what they saw. The large teeth and truncate base will distinguish this from all others besides the procumbent stem.

563. Celtis tenuifolia Raf. (or parvifolia) C. pumila Pursh, T. B. \&c. C. occid. var. tenuif. Lam. Pers. Nuttal ? \&c-shrubby erect branches divaricate, branchlets angular smooth leaves uniform ovate acuminate, serrulate in the middle, base acute obliqual unequal entire trinervate, both sides smooth, pedicels axillary 
uniflore longer than petiols, fruits round oboval brown-a shrub 3 to 5 feet high, erect with spreading branches, found by myself in the hills of Maryland, blossoming in May, said to grow also in the Mts. of Virginia and in Louisiana, easily known by the few small teeth, leaves 1 or 2 inches long rather thin.

564. Celtis heterophyla Raf. shrubby, branchlets smooth terete rugose, leaves multiform, ovate or cordate, oblong or lanceolate, base hardly obliqual rounded or cordate, end acute or acuminate margin entire or with a few teeth, but all smooth thin with nerves reticulate beneath, pedicels axillary uniflore longer than petiols, young fruits ovate-sent me from Alabama, a very singular species offering all kinds of leaves on the same small branches ( 1 or 2 inches long) yet unlike any of the other shrubby kinds. Is it the C. pumila found by short and Riddell in Kentucky?

565. Celtis patula Raf. shrubby diffuse, branches divaricate, branchlets angular smooth leaves uniform cordate acute, entire or serrulate in the middle, rough above, beneath smooth reticulate, base not obliqual, petiols and pedicels very short-from Florida, humble shrub, branches quite divergent, sometimes reflexed, leaves over one inch long and broad, pale above as in C. alba. Near to C. reticulata, which differs chiefly by leaves pubescent obliqual obtuse.

566. Celtis floridana Raf. shrubby, branchlets angular pubescent above, petiols pubescent very short, leaves broad ovate obliqual acute serrulate in the middle above rough rugose, beneath reticulate by grey pubescent nerves, pedicels short but longer than petiols, fruit depres- 
sed ?-Florida and Alabama in the hills, leaves uncial, base and end quite entire, middle teeth sinall but close subequal.

\section{Genus ULMUS.}

Without giving a complete monograph of all our EIms, I will try to rectify and improve this Genus by adding 5 to those already known or admitted. There are several overlooked sp. of it, since 'Thomas has quite lately described the U. racemosa from New York: the others known are $U$. americana, nemoralis, fulva and alata, to which $I$ shall add $U$. longifolia. oborata, aiba, dentala and dimidiata; thus we know already $10 \mathrm{~N}$. Amer. Sp. and there are more perhaps, those of Origon are not yet described.

567. Ulinus longifolia Raf. shrubby, branchlets slender smooth striated, leaves on short petiols, smooth on both sides, thin, oblong elongate, base subcordate hardly obliqual, end acuminate, margin duplicate serrate-Alabama and Tennessee, near to $U$. clata, but branches not winged and leaves longer subcordate. A shrub 8 to 10 feet high, leaves 3 to 4 inches long about one wide.

568. Ulwus obovata Raf. 'Tree, branches patent, branchlets terete smooth rugose, leaves ample on short petiols obovate acuminate, base obtuse obliqual, margin duplicate serrate, nearly smooth above, villose beneath-in Kentucky and Illinois, a tree 30 to 10 feet high, with large leaves 4 to 6 inches long, 3 to 4 wide, near to the two next which differ by oblong leaves and white hanging branches, or ovate rough leaves \&c.

569. Ulyus alba Raf. fl. lid. 387. U. Amer. Var, pendula of Authors-'Tree with hanging 
branches, bark whitish, leaves oblong, base acute obliqual, duplicate dentate, roughish and lucid above, villose beneath-in Louisiana and other States, 50 to 60 feet high, long flexible branches. As this with the last and next are often blended under the vulgar name of White EIm, I must add what I consider as the real U. Americana.

570. Uluus anemicana L. Authors: (sessilis Raf. better name.) 'T'ree, branches divargent, branchlets terete smooth rugose, leaves subsessile ovate acuminate, duplicate serrate, base very obliqual subcordate, above rough, beneath soft hardly pubescent-chiefly in the Alleghany mts. large tree 60 to 80 feet high, leaves 3 to 4 inches long 2 or 3 broad. Thus quite distinct from both the preceding.

571. Uluus dentata Raf. 'Tree, branchlets terete smooth, leaves ample and thin, on long petiols, obovate, base acute entire, not obliqual, large sharp teeth above, end subacuminate, smooth on both sides, fruits fasciculate peduncled oblong bifid fimbriate on the sides-a fine new Elm, sent me from Alabama as $U$. fulva, but totaly unlike, much nearer to $\boldsymbol{U}$. nemoralis? which differs by oblong leaves and sessile flowers. Leaves very large 6 to 7 inches long, 3 to 4 broad, petiols over one inch longer than in any other sp. the large subequal teeth are only in the upper half, fascicles of flowers multifiore, pedicels filiform, calix campanulate,stamens exserted, pistil cuneate oblong bifid by the 2 styles. It is called the yellow EIm.

572. Ulues mimidata Raf. shrubby, branchlets smooth angular, leaves on very short petiols, quite smooth biforme, some smaller ovate 
acute, some larger oblong acuminate dimidiate, all equaly serrate, base very obliqual, often one side decurrent the other reduced in size or dimidiate.-In Florida and Georgia, shrub 8 to 12 feet high, leaves pale subcoriaceous, 1 or 2 inches long, in the narrow leaves the base of one side is removed upwards of the petiol and that side is much reduced in size whence the name: unlike any other sp. very singular and curious, fruit not seen. The fine U. alata is alone somewhat akin in size of shrub and leaves I have found that fine sp. in Kentucky and have it also from Tennessee and Arkanzas. The $\boldsymbol{U}$. pinguis or fat EIm of Louisiana must be compared and distinguished if different from both. 'The $\boldsymbol{U}$. pumila of Walter is said to be the U. alata.

This fine and useful Genus was thus like Celtis in great disorder, Linneus united six European sp. in his U. campestris! and we have nearly as many in our White Elms! It is now supposed that U. nemoralis is the Planera aquatica and also Rhamnus carpinifolia! being put into 3 Genera! and although Sir James Smith doubts the fact, he acknowledges having seen only one kind. I have not yet obtained the Planera and cannot clear the subject; but all our botanists distinguish it from U. nemoralis, altho' they cannot show distinct specimens of both, if two they are both called Water Elm. Elliot omits the U. nemoralis, but describes twice the Planera in pentandria and polygamia! I hope my remarks and new sp. will make this Genus better known. Abelicea or Planera will only be perhaps a subgenus of Ulmus, merely distinguished by polygamy and capsule 
swelled obliqual reticulate or squamose. $3 \mathrm{sp}$. Abelicea cretica, sibirica, and aquatica our own.

573. PLEUROSTENA Raf. fl, tel. 413. Calix rhomboidal 5fid unequal. Stamens 5 subequal, stigmas 3 sessile. Seed conical longer than calix, unequal trigone, one side narrower. Flowers axillary polygamous. One of the 20 Genera blended in Polygonum, revised by me in $\mathrm{fl}$. tel. The type of this is a sinall western shrub. The name means narrow side.

574. Pleurostena serotina Raf. Polyg. do Raf. An nat. 93. Suffruticose, stem striate much branched, branches angular virgate, leaves ncarly sessile ovatoblong acute smooth, sheaths split lacerated, flowers axillary fasciculate-discovered and published in 1820, a small shrub 2 or 3 feet high woody only at the base, quite autumnal blossoming late in October, growing in fields and glades in Kentucky. Leaves quite small, flowers green 2 to 5 together on short peduncles, often polygamous by the abortion of stamens. Different from Stopinaca fl. tel. 405 or Polygonella of Mx. which I have also.

575. SPERM IULAXEN Raf. fl. tel. 416. Monoical, male fl. campan. 4-5fid, segments subequal obtuse colorate. Stam 4-5 very short, female fl. similar larger more unequal, segments erect obovate, stigmas 2-3sessile. Seed pyramidal double of calix trigone, base concrete, one side concave canaliculate. S/ırubby $\boldsymbol{f}$. spiked - another very distinct G. of same tribe akin to the last, to which perhaps belong also the exotic sp. blended as Polyg. ochreatum 
and grandiflorum. The name applies to the sulcate seed.

576. Spermatlaxen dichotonus Raf. stem shrubby dichotome sulcate, leaves petiolate oblong lanceol. acute smooth, margins rough, sheaths obsolete, spikes filiform, flowers remote some are peduncled-Florida, found without name in Col. herb. flowers small purplish male and female on same spike, no tubular sheaths but instead a small subulate deciduous stipule in some leaves and flowers.

577. TOXYLON Raf. 1817 in Mus. Nat. Sc. misprinted Ioxylon (an I for a 'I) corrected in Med. flora Vol. 2 page 268. Maclura of Nuttal 1818 posterior name, and a Genus of shells was since called after Maclure who was no botanist! Moleus or Birussonetia tinctoRIA ! of Sprengel Kunth and Torrey! not of Linneus, quite a different tree ... I was the FIRst to describe this Genus of trees and give it a better name than Nuttal. His name however was adopted by some botanists, while others blundered so far as to blend it with the tropical Morus tinctoria of Linneus, I corrected this mistake in $\mathbf{1 8 3 0}$ in my medical flora, Nuttal has also corrected it in $\mathbf{1 8 3 4}$ in his plants of Wyeth; but without mentioning my previous name!-I gave a long account and history of it in 1817 to which I refer Amer. Monthly Mag. Vol. 2 p. 118, and will only recapitulate the main characters here: adding the real $\boldsymbol{I}$. tinctoria (to evince the difference) which forms the Genus Fusticus.

Characters of Toxyus Raf. flowers dioical in catkins, male fl. calix 5parted, 5 stamens, female fl. in globular fleshy catkins, calix immerseal pentiagonal concrete, Ovary oboval 
simple deciduous filiform villose stigma simple fiuct a fleshy syncarpe or concrete berry by coalescent berries verrucose tesselated as in Artocarpus, forming many cells at the periphery, each with one seed obovate. Spinuse tree woith alternate distichal leaves, fruits large axillary.-Thus intermediate between Artocarpus and Fusticus. My name means Bonwood (Ioxilon would have meant arrow-wood) one of its name.

578. Toxylon maclura Raf. 'T. pomiferum Raf. 181\%. Maclura aurantiaca Nuttal 1818, Eaton. Brouss.tinctoria Spr. K. 'I'orrey! Leaves smooth lucid ovate acuminate petiolate entire, a recurved spine near their base, fruits oiange like, axillary subsessile drooping-in Arkanzas, Texas and upper Missouri, a small tree 20 to 30 feet high, branches spreading, leaves 2 to 4 inches long, petiol about one inch, fruits size and shape of an orange, nearly same color, but structure like the bread fruit or pine apple, containing a sweet emylaceous milk. Wood yellow tough and heavy, used to make excellent bows, bark affording a fine flax. Tree easily raised from cuttings and layers, forming excellent hedges. Called Ayac by the Indians, also Bow-wood, yellow wood, stinking wood, Osage apple. - I made two oversights in my first account of this valuable tree in 181\%, calling the leaves serrate and wood used for arrows. Seen alive in many gardens with flowers and fruits. Nuttal calls the nerves puberulent beneath, they are only so when young, the flowers and styles are yellow.

579. FUSTICUS Raf. Fustic tree difiering from Morus or Mulberry by female Catkins globular, flowers distinct, calix scariose Apar- 
tite, sepals unequal obovate obtuse, ovary obovate compressed, a single style terminal smooth filiform flexuose, a single stigma. Fruit a globular compound berry or syncarpe by baccate calix as in Morus, concrete at the base but distinct at the end, seeds compressed. Trees distichal serrate leaves, fruits axillary pendulous-several blended species. If the good name of Fusticus does not appear classica enough, I propose for substitute Sukaminea name of Dioskorides for the Mulberry. This G. is nearer Broussonetia than Morus and Toxylon. The first only differs by fem. calix tubuhar 3-4dentate, style lateral, seed clavate: the Morus differs from all 3 by the double styles and stigmas, with the oblong fruits. My G. Calostima fl. tel. 589 which was the Urtica baccata of $\mathbf{I}_{\text {. }}$ is akin to all these, a connecting link with Basella, it differs by the many radiated stigmas and racemose fruits not forming a syncarpe, All are deemed to belong to the tribe of Urticides or Nettles, forming a peculiar group Monines by baccate seeds. Sir J. Smith regreted that the blended Fustic trees had not been well distinguished, I shall try to distinguish 4 of them.

580. Fusticus grabra Raf. Broussonetia tinctoria Jalambic in Collins herb. Branches terete inerme yellowish punctate of white, petiols very short, leaves quite smooth ovatoblong repand or serrate in the middle only, base obliqual subcordate, end acuminate elongate, female catkins on short peduncles-in South Florida and Cuba. It is on this sp. that I have framed the Generic character. Leaves $\mathbf{2}$ or $\mathbf{3}$ inches long without spines, catkins small not one fourth of Toxylon. It is probably this sp. 
that is meant by some writers, but I cannot ascertain the synonyms; yet I can vouch that it is quite unlike my Toxylon, having seen both. The flowers are pale yellow, styles of same color, fruits not seen.

581. Fusticus vera (or tinctoria) Raf. Morus tinctoria Lin. syst. nat. Mant. not sp. pl. Miller, Brown, Sloan, Smith \&c. Bark yellow leaves oblong acute entire rough, base obliqual cordate, no spines-in Central America, Yucatan, Jamaica \&c the real Fustic of dyers, a large tree 60 feet high, fruits sweet eatable size of a nutmeg.

582. Fusticus xanthoxy yon Raf. Morus do Lin. Syst. nat. et Mant. 495. Smith, Morus tinctoria Lin. sp. pl. Poiret, Jaq. t. 247. Pluk. phyt. t. 239. Bark grey, leaves ovatoblong acute serrate nearly smooth, base obliqual, spines axillary half uncial equal to petiols.From Yucatan to Bahama, it is the Bastard Fustic a smaller tree 40 feet high, it was the original M. tinctoria of $\mathbf{L}$. but he since described the real one above: Lamark again blends them; but they are quite distinct botanicaly and economicaly as proved by Smith, the wood being less valuable as a dye. Perhaps found in Florida.

583. Fusticus tataiba Raf. M. tinctoria L. Sm. Poiret ofc. Tatai-iba Marcgrave hist. braz. 119 fig! Bark grey, leaves petiolate ovate lanceol. acumin. serrate or repand smooth, base acute not obliqual nor cordate, no spines, fruits subsessile-Brazil, a very distinct sp. figured 150 years ago. A very large tree, with leaves like the Beech tree. Fruit pretty large sweetly acid eaten with wine and sugar, the flowers are pale, the styles brown. I have verified the 
figure-the Quechue of Orinoco mentioned by Caulin p. 15. is probably another Fustic, the fruit is green and sweet falling as soon as ripe.

591. Brovssonetia Papyrifera Duhamel, W. Éc Papyria of́ Lamark, Morus papyrifera L. Sim. \&c. A well known usefin tree native of Japan and Polynesia, now introduced in the open grounds of Wurope and America, quite common in our gardens where it bears the winter pretty well, altho' injured sometimes by frost. We have oniy the male trees.

\section{Genus MORUS.}

585. Monus alba L. a c. A well known tree, now widely spreading with us, almost wild in some localities. White Mulberry. This is said to be constantly monoical, but the other sp. are often dioical and polygamous.

596. Morus nigra L. \&c. Black Mulberry, also cultivated for the fiuit.-C'The best Monograph of this Genus are those of Lamark and Smith, including the Fustic trees however; but Lamark has a new American sp. MI. canadensis, and Wildenow another MI. Scabra, I can add 4 others besides the M. multicaulis. Eaton has only 3! Nuttal admits the M. scabra. I have 9 whereof $y$ seen alive and one dry.

58\%. Monts rubra L. our well known Red Mulbery found firom Canada to Louisiana. It has some Var. I pallida fruits pale, 2 heterophylla with all the leaves unlike. Often dioical like all on American kinds. It is even stated that the same trees often vary each year in their seres?

588. Mones rmaria Raf. distinct from M. rulua by long petiols, sinooth leaves ovate deeply cordate, schlom lobed lateral, quite smooth and thin crenate serrate, acute not acuminate, 
and not obliqual at base. Found in the Alicghany mis. on the banks of the Susquehanah, leaves 3 to 5 inches long nearly trincrve at base nerves yeliow quite smooth, berries dark red, called the wild black Mulberry, or Water Mulberry. A preity tree growing even among rocks.

589. Monus caradensis Lamark. leaves ovate obliqual base rounded not cordate, serrate nearly smooth long acuminate-in Canada Maine and the Alleghanies, calied the Rock Mulberry, fruits not seen.

590. Morus parvifolia Raf. Ilonoical, petiols long and slender, leaves small and smooth, ovate acute or obtuse not lobate, equaly subcrenate, base truncate often obliqual,fruits short on very short peduncles.-MIs. Alleghanies and Apalachian, called the Indian Mruberry, said to have been cultivated by the Indians, often mistaken for the White IF Fulberry, the fruits being very small ovatoblong of a flesh color and sweet. Leaves only 1 or 2 inches long, not so thin as in $R$. riparia, petiols over one inch. Male catkins on same branches, with longer peduncles, segments of calix rounded. Styles very short.

591. Monus scamea W. entim. Lcaves ample thin trilobed, base cordate, rough on both sides, pale beneath, serrate, large tecth interjected in the sinusses, fruits terete black acidin Louisiana called the black Indian Mulberry, communicated to me by Di. Nease. Leaves 5 to 8 inches long and wide, lobes acute not acuminate, lateral lobes oblong, terninal oval or narrowest at base.

592. Morus momextoni leaf. fl. lud. :379. Leaves broadly cordate acuminate dentate. 
above lucid rough, beneath tomentose, spikes often monoical, fruits oblong white-in Louisiana, well noticed by me in $\mathbf{1 8 1 7}$ in my flora of Louisiana where detected by Robin. It is the White Mulberry of the S. W. often mentioned by the old travellers. A large handsome tree, bark white and smooth, it blossoms in March, male catkins terete and loose, female shorter and thicker, but they are generaly united, the male flowers being then at the base.

593. Morus multicaulis Raf. and of Gardeners, not introduced yet into our books, nor do I find any botanical account of it, even in Loudun Cycl. A small shrub with many stems and ample leaves, cordate rounded not obliqual, nor lobed, crenate, acute, somewhat rough, but thin. I have seen leaves one foot long and wide. Native of China and the Philipines, lately introduced and much esteemed as the most productive for the breeding of silk worms and easy gathering of leaves. But all our Mulberries are eaten by the silk worm, and the $\boldsymbol{M}$. rubra produces a fine strong silk. - As the subject of silk culture now begins to attract much attention, I hope this account of all our Mulberries will be acceptable.

N. O. EMPETRIDIA Raf. 1815. EMPETreae Nut. 1818, Don 1826, Torrey 1835 !

I first noticed this order in my Analysis of Nature 1815, therefore 'Torrey is wrong to ascribe the discrimination of it to Nuttal 3 years after, who had besides deemed it only a section of Conifera! while I had perhaps properly united it to Phytolacca! and if the berry is multilocular they are quite akin notwithstanding the remote habit. I have since in my Flora tellur. 
633 revised it and separated by the unilocular berry, reducing to Sarcocrdia the Genera Phytolaca, Raxamaris, Schefferia \&c, and to $\mathbf{R}_{\mathbf{I}}$ vinidia the pretended Chenopodea with a berry.-The Eupetrides are more akin to those than to Euphorbides and Celastrides, and are quite unlike to Conifera. The genera belonging thereto are Grubbia, Coilosperma, Batis, Ceratiola \&c besides the types Empetrum and Colema.... but the Genera Skimmia, Nandina, Melicytus \&c are very near also. The whole requires a careful revision.

594. COLEMA Don 1826. Eureucum Raf. 1886 fl. tel. Dioical, calix 5-6parted, stamens 3 to 4, style 3-4parted, berry 3-4locular, 3-4 sperm. Evergreen shrubs, habit of heaths, flowers terminal and axillary glomerateThis had been based on the Empetrum album of $\mathbf{L}$. but our sp. may be of quite a different Genus, the real Colema having the ternary part constant, no style but 3 stigma, a berry nearly monolocular when ripe. Therefore it must form the subgenus Euleuca, and our sp. with heterogonal parts and stamens, a style, and probably a 4locular berry must form a subgenus Endammia Raf. if not a Genus, meaning in sands.

595. Colema arevaria Raf. or Endammia ericoides Raf. Empetrum conradi, Torrey 1835. Cespitose procumbent smooth. leaves subverticillate and alternate, narrow linear acite glandular, margin revolute, flowers glomerate and capitate-in the sandy tracts among the Pine woods of New Jersey, first noticed by Kin in 1800, who gave it to me as an American heath in 1802, found by me in 1804 near Pemberton, long before Conrad, and twice again in 1833 at 
Cedar bridge; but always without flower's and seeds. It must blossom in winter or very seldom. Torrey only sav the flowers dry and in a garden and omits to state the time, his account is however very good. It is a small evergreen shrub 5 to 10 inches high, much branched and growing in patches like the Hudsonia.

596. Ceratiola ericoides Mx. and all botanists, Hooker bot. mag. 2758. From Carolina to Florida, well described by Michaux, Elliot, Hooker \&c. I have many specimens, in which the leaves are mostly fallen as in the dry Heaths.

59\%. Eupetrum purpureum Raf. E. nigrum Mx. and all our Amer. botanists, not of Lin. and European bot. E. rubrum Lapilaye fl.Procumbent smooth, leaves scattered crowded, lower patent, upper imbricate, oblong linear sessile uninerve obtuse flat on both sides, thickish, berries purple, sessile equal to the leaves and costate-in Canada, Labrador, Newfoundland, White Mountains, Lake Superior, near the rocky shores. Michaux who first noticed this blended it with the boreal sp. of Europe, and has been followed by all our subservient botanists except Lapilaye who has blended it with E. rubrum of Austral America in his Newfoundland Flora. My specimen is from Labrador and has red berries strikingly like those of Phytolaca! Those of our Botanists who saw the berries are few, they mostly copy Michaux! is there a sp. in boreal America with black berries? My sp. is perfectly distinct, the branches are terote smooth but sulcate among the leaves, these are only 2 or 3 lines long, with a single nerve beneath not at all revolute and hardly any verticillate; the flowers and berries 
are solitary near the end, calix scaly of about 6 unequal ovate and obovate scales persistent much shorter than the large berry which has about 9 oblong seeds and is crowned by as many thick stellate clavate stigmas.

598. Empetrum nigrum L. and all European bot. A boreal plant of which I have specimens from Sweden and the Alps. 'They answer to the Linnean description of it by leaves quaternate petiolate ovate lanceolate obtuse, berries black subsessile. Therefore quite different from our American species; but I have also specimens from Sibiria and the Alps nearer to our sp. and therefore there may be two species in Europe as probably also with us. Wildenow thus say $\boldsymbol{E}$. nigrum has oblong revolute leaves.

599. Enpetrum crassifolium Raf. smooth procumbent, leaves 3-4nate petiolate linear obtuse thick, flat above, convex enerve beneath, patent crowded.-Sibiria and perhaps other parts, my specimens have no berries, and but few flowers, leaves 3 lines long, quite thick, sometimes sulcate beneath, but not nerved,some appear to be fistular: flowers as in $\mathrm{E}$. nigrum, sent me as such. Is it found in Origon? berries probably black.

Shrubby LABIA'TE.

600. RAFINESQUIA or DIoDerLIS R. fl. tel. 750. Cunila, Melissa and Gardoquia of Authors!.. Calix tubular strait striated subbilabiate upper lip bidentate, lower tridentate, mouth closed by hairs, corolla tubular erect bilabiate, upper lip concave notched, lower 3lobe subequal stamens 4 remote, anthers cordate bilobe, seeds smooth. Shrubby, flowers axillary red.-A very fine peculiar Genus forced into 3 alien 
Genera, I have proved in flora tellur. how different is Gardoquia. It is one of the Genera to which I give my own name, and if any one cavils at it I offer a second abridged from Diodontocheilis! that 1 may not lose the merit of my sagacity in ascertaining this Genus. I have already two sp. of it.

601. Rafinesquia coccinea fl. tell. 751. Cunila! do Hooker, Melissa! do Spr. Gardoquia! hookeri Benth. Don. Lindl. b. reg. 1747. Shrubby smooth, leaves obovate sessile subacute, peduncles axillary 1-3flore-A small shrub of Florida with handsome large scarlet flowers, branches terete sub 4 angular, leaves commonly remote small.

602. Raf. coccinea var. obtusifolia Raf. differ. branches more 4 angular, leaves equal to internodes obtuse one third inch long, flowers scarlet over one inch long.

603. Rafinesquia angustifolia Raf. suffruticose, branches filiform hardly angular,leaves sessile smooth oblong or cuneate obtuse crowded above, peduncles very short uniflore-in Alabama, smaller shrub still with narrow leaves and smaller flowers rather red than scarlet. Given me as a var. of $\mathbf{R}$. coccinea by Durand; it is very near Gardoquia chilensis in habit, but quite cinlike in the calix and flowers.

604. PILOBLEPHIS Raf. Satureia and Cephalothymus Benth. Quite a peculiar G. discovered by Bartram 60 years ago, unnoticed by all our botanists, altho' in their herbals! until Bentham found it in Banks Herbarium, but he left it with Satureia as a subg. with an im. proper name, mine means ciliated head. It differs as much from Satureia as Pycnanthes does, both by characters and habit. Shrub 
with habit of Ericas and Empetrum, flowers capitate without involucre, but many ciliate imbricate bracts, calix large membranaceous 5fid subequal campanulate, corolla nearly as in Satureia, 4 filaments and anthers, seeds 1 or 2 at the bottom of the large calix - this will probably be like Pycnanthes an American Genus of many sp. but now I know of only one type. All the Satureias are foreign to America.

605. Piloblephis rigida (or ericuides) Raf. Satureia rigida Bartr. 1775, Bentham. Anonymos N. G. Baldwin in Collins herb. Śhrubby decumbent, branches terete rigid leaves imbricate linear obtuse smooth margin revolute, flowers in terminal globular heads, bracts linear lanceol. obt. hairy ciliate as long as flowersShores of Florida, in sands, small procumbent Shrub quite evergreen, flowers incarnate concealed among the bracts. If this shrub has been unnoticed for 60 years (after Bartram) in our books, I may hope that in 60 years hence my new plants will also be properly noticed again ! . . . Bartram did not describe it, I describe my new plants! Baldwin found it again in 1816 and deemed it a new genus as I do, altho' he neglected naming it like so many other rare plants of his.

606. Audibertia incana Benth. Lindl. b. reg. 1469. Suffruticose glaucous, leaves cuneate and obovate, flowers verticillate, bracts orbicular ciliate-Origon, a N. G. of Bentham with habit of Origanum, but very distinct by 2 stamens like Cunila, flowers blue, calix ovate bilabiate, upper lip entire, lower bifid, corolla tubular, subbilab. upper lip bifid, lower trifid, medial lobe notched, anthers dimidiate. Not 
in Eaton, nor any of the above shrubby Labiate.

MONOGRAPH OF CEANOTHUS.

This pretty and useful natural Genus deserves a complete examination, being now greatly increased in species: they are all small shrubs, or bushes, but some are perennials. Linneus had only one, Michaux, Bigelow, Nuttal Hooker and myself have added many others, altho' Eaton enumerates only 6. All have estival white flowers in thyrsoid corymbs, but $C$. azureus has blue flowers. Leaves alternate with short petiols. Roots red and medical see my Med. flora. This G. commonly united to the Rhamnides, rather belongs to the Phylicides with Phylica, Bumalda, Brunia, Hovenia, Colletia, \&c, having all fruits coccular as in Euphorbides; but the stamens are opposed to petals and often inserted thereon. 'The Asiatic and African sp. of this G. appear to form peculiar genera, the asiatic form the $G$. Carpodetus, the polynesian the G. Pomoderis, and the African must form my G. Iypcina, see fl. tel.

60\%. Cennothus officralis Raf. Med. fl. 2 p. 205. Americana L. and Authors, now become an absurd name, the whole $G$. being American-Shrubby, branches terete smooth fuscate leaves ovatoblong acum. serrate trinerve pubescent and pale beneath, petiols pubescent, base rounded, panicles lax terminal or on long peduncles angular, pubescent. pedicels geminate or fasciculate-from Canada to Alabama and Louisiana, 2 or 3 feet high, leaves 2 or 3 inches long, end often obtuse altho' acuminate, flowers very small, panicles often with one or two small leaves. Var. 1. Otratus, leaves rather oval, 2 Acutus all the leaves acute. :3 
Paniculatus large compound ovate panicles. 4 Foliosus, with foliose panicles.

608. Ceanothus gloneratus Raf. americ. Elliot. Shrubby branches pubescent angular fuscate, leaves ovatoblong acute at base and apex, serrulate trinerve, petiols and nerves pubescent fulvous, panicles glomerate axillary on long hairy peduncles, pedicels short crowded with lanceolate bracts - in Virginia, Carolina, Tennessee, Alabama, Kentucky \& c commonly blended with the last, leaves smaller with fuscate or rufous nerves pale beneath with few. hairs except on the nerves, flowers on smaller panicles glomerate crowded larger, the small bracts often fall off in the anthesis. Var. fuscatus, with dark fuscate branches and nerves, even leaves fuscate above, flowers quite glomerate. Both 2 or 3 feet high. Root more astringent and darker red.

609. Ceanothus latifolius Raf. americ. var. tardiflora Eaton. Shrubby, terete pubescent fuscate, leaves broadly oval, base subcordate, unequaly serrate acute trinerve, petiols hirsute, quite villose and glaucous beneath, panicles lax ovate compound axillary, peduncles villose cinereous bifoliate-Glades of West Kentucky and Tennessee, stem 2 or 3 feet, leaves large 3 or 4 inches long, 2 or 3 wide, panicles with shorter peduncles, but long pedicels.

610. Cean. herbaceus Raf. 1808 Tor. Beck Eaton (or C. levigatus) C. perennis Pursh, Nut. El. Perennial, quite smooth, stem simple annual terete fuscate, leaves ovate acum. base acute, trinerve serrulate, glaucous beneath nerves fuscate, panicles lax thyrsoidal-Virginia and Carolina near streams, disc. by Hings- 
ton in 1800 at the falls of the Potowmak, where found by me again, stems 1 or 2 feet high seldom branched, leaves as large as in C. glomeratus, peduncles, and flowers similar to it, but not glomerate quite lax.

611. Cean. ellipticus Raf. Shrubby, leaves remote elliptical hardly serrulate trinerve obtuse, beneath puberulent, raceme thyrsoidal small on short petiols and bracteated-Apalachian Mts. of Georgia and Alabama, Cheroki and Wasioto Mts. one or two feet high, leaves small on very short petiols, flowers small with bracts as in C. glomeratus.

612. Cean. virgatus Raf. intermedius Mg. El. P. N. Shrubby, branches elongate slender virgate subangular smooth rusty, leaves broadly lanceolate acute subserrate trinerve, nerves and petiols pubescent, racemes short corymbose lax -from Virginia to Florida, pedal or sesquipedal, with some long branches at the base, leaves small uncial narrow, panicles quite small on long peduncles, formed by two or 3 small umbels.

613. Ceanothus? atropurpureus Raf. Shrubby, quite smooth, branches terete spreading rigid dark purple, leaves subsessile oblong entire, lower acute, upper obtuse, not trinervate, tip of petiol and base of main nerve often bearded-I refer protem to this Genus, a doubtful shrub of Florida, found without flowers in Collins Herb. owing to the similarities of habit with the last and next sp. but it may turn out to be something very different, perhaps an Ilex? or Bumelia? Leaves just like the last in size, but entire or slightly erose, and petiols exceedingly short. 
614. Cean. sanguineus P. N. Hook. Eat. Shrubby, branches purple, leaves subsessile cuneate oblong serrate pubescent beneath, panicle axillary glomerate, flower's crowded-regions of Missouri and Origon, seen dry, shrub 3 feet high.

615. Cean. alandulosus Raf. ovalis Big. Beck, Eat. ovatus Dec. intermedius Hook. fl. interm. var. corymbos. Mg. Perennial? stem sulcate pubescent, leaves ovatoblong obtuse some obovate, glandular crenate trinerve, petiols and nerves pubescent, panicle terminal corymbose formed by lax umbels-Canada and Lake Champlain, a very distinct sp. my specimen is quite heterophylous, the name of Ovalis does not apply, blended with my Southern C. virgatus by Hooker, leaves 1 or 2 inches long, large flowers, peduncles calix and corols white. Apparently not shrubby. This was my Forrestia thyrsoides of 1808 but it is not even a subgenus, unless the glandular leaves of this and the 3 next appear to indicate one.

616. Cean. velutinus Hook. fl. tab. 45. Shrubby, leaves rounded elliptic coriaceous glandular dentate trinerve, white tomentose beneath, panicles terminal thyrsoidal foliose at base-in the Origon Mts. not seen by me, adopted from the good figure of Hooker, and I add two others of his to complete this monograph.

617. Cean. levigatus Hook. fl. difiers from last by, quite smooth, panicle quite foliose, flowers glomerate-found at Nutka by Menzies.

618. Cean. Bicolor Raf. thyrsiflora Esholtz and Hook. fl. shrubby, branches angular, leaves subsessile oblong trinerve, nerves pilose, glandular serrate, panicle thyrsoidal base folioseNew Sibiria in N. W. America, calix bluc, pe- 
tals white, whence my name, since all the sp. are thyrsiflore.

619. Cean. azureus Desf. ic. 232. Lod. cab. 110, Edw. b. reg. 291. Dec. Shrubby pubescent leaves ovatoblong acute rough serrate, beneath tomentose, panicle thyrsoidal, base foliose, flowers blue-in Mexico, New Mexico and Texas, an elegant species.

620. Cean. microphylus Mx. E. \&c. Shrubby much branched, quite smooth, branches divergent, leaves fasciculate minute oboval or rounded obtuse trinerve, racemes terminal corymbose-Florida, Georgia, Alabama, a very peculiar sp. habit unlike the others, but like the next, flowers vernal as in the Southern species.

621. Cean. serpyllifolius Nut. Eat. Decumbent bushy, branches filiform, leaves minute nearly smooth elliptic ovate obtuse serrulate, petiols and nerves strigose, panicles axillary peduncled pauciflore glomerate-Florida, very small, habit of thyme like the last, and probably both ought to form a subgenus. Is it only a var. of it? Elliot has blended both; disc by Dr. Baldwin near St. Mary.

\section{Genus EVONYMUS.}

Without giving a complete monograph of our sp. I can greatly increase them having 4 or 5 new ones to describe. They form 3 subgenera with opposite leaves and axillary peduncles. This $\mathbf{G}$. had been wrongly united to Rhamnides, since the stamens are alternate to petals, and the fruit is peculiar, it belongs to a peculiar family (with Tobira) near to the Celastrides. T'obira differs by 6 stamens and caps 3loc. polysperm.

622. Platomesus Raf. calix 4lobed, 4petals, 
4 stamens, capsule commonly 4lobe 4loc. 4 sperme.

623. Pentinius Raf. cal. 5dentate, 5 petals, 5 stamens, capsule commonly 5lobe 5loc. 5 sperme.

624. Priyscondra Raf. calix inflate membranaceous entire or subcrenate, petals 4 or 5 , anthers 4 or 5 sessile, capsule 4 or 5 sperme.

625. Evonymus (Platom) cuneatus Raf. Branches terete smooth, leaves cuneate acute serrulate smooth, peduncles trifiore longer than petiols, petals 4 oblong obtuse-Origon region, shrub 4 or 5 feet high, branches naked below nearly articulate, petals white, fruit not seen, leaves uncial terminal.

626. Evon. (Platom) heteropmylus Raf. Branches subangular smooth subrugose, leaves dissimilar cuneate or obovate acute, or elliptical acuminate, entire or serrulate, rugose beneath, peduncles biflore elongate longer than petiols, pedicels divaricate, petals 4 obovate obtuse, fruits smooth-A palachian Mts. shrub 4 feet high, petals white, fruits incarnate $\mathbf{2}$ to 4 lobed.

627. Evon. (Platom.) acuminatus Raf. Branches terete smooth, elliptic acuminate, base acute, subcrenate, some lower ones obtuse or retuse, peduncles elongate 1-2flore, petals 4 cuneate obtuse, fruits smooth deeply lobed.-Origon and Sibiria, has been blended probably with E. europeus, which I have also and differs by smaller narrower entire leaves and peduncles multiflore as long as leaves. This has large leaves on long petiols, the petals white fruits red with 2 or 4 lobes.

628. Eron. (Pentinius) murrcatus Raf. americanus L. \&.c. Branches 4 gone smooth, 
leaves subsessile ovate or lanceolate acute or acum, serrate, peduncles 1-3flore, petals 5 obovate, capsules muricate verrucose-from Canada to Carolina in Mts. Shrub 4 to 6 feet high, branches rigid, leaves middle size, petals greenish white with rose tinge. Several varieties 1. Biflorus, leaves all lanceol. acum. subserrate, peduncles all biflore, petals rounded unguiculate. 2. Obliquatus, leaves ovate lanceol. commonly obliqual, peduncles uniflore, Mts. Alleghanies.

629. Evon. (Pentinius) sarmentosus Raf. amer. var. sarm. Nut. Eat, \&oc. Stem sarmentose 4gone radicant, leaves subsessile ovate lanceol. acute undulate crenate opaque lucid, peduncles 2-3flore, fruits scabrous-Rocky woods of the Alleghany Mts. and River Susquehanah, certainly a distinct sp. forming a Vine 10 to 20 feet high with many slender branches.

630. Evon. (Pentinius) angustrifolius Lyon, Pursh, El. Eat. \&c. A rare species of the Apalachian Mts. of Georgia and Alabama, not at all doubtful, my specimen from Lyons in Collins Herb. has slender 4 gone branches, leaves remote subsessile narrow lanceol. acute falcate entire, peduncles erect uniffore with 2 setaceous bracts.

631. Evon. (Platom) atropurpureus Jaq. and all Authors. A fine shrub 6 to $\mathbf{1 5}$ feet high, assuming the appearance of a small tree, near streams chiefly from Carolina to Kentuc$\mathrm{ky}$, Missouri and Origon, fiowers dark purple, 3 Var. 1. ublongifolius, 2 latifolius leaves ovate and obovate acum. 3, grandifolius large éliptic leaves 5 to 8 inches long.

632. Evonymus (Physcondra) obovatus Nut. 
\&c. A very small sp. well described by Nuttal, creeping pedal, found from New England to Ohio. Almost a peculiar Genus by the shape of calix, but petals as in E. muricatus-'Thus I have nearly rectified this $G$. and $8 \mathrm{sp}$. of it. My N. sp. are distinct from $\boldsymbol{E}$. verrucosus and latifolius of Europe which I have.

Natural family of SPIRADIA.

The Linnean Genus Spirea has been kept nearly entire by Decandole but divided into subgenera, that differ so much in habit and characters that they ought to become Genera. Filipendula of 'Tournefort, Aruncus of Adanson, Gillenia of Mench, now generaly adopted, and Purshia of Decand. are certainly peculiar Genera, as well as my G. Thecanisia, Epicostorus \&c. As early as 1815 I formed a new family the Sprrades in my Analysis of Nature page 173 with these Genera, adding Rhodalix, Ba silima, Drymopogon; the Genera Tigarea, Neil lia? 'Tetracera, Suriana, \&c probably belong to it. This natural family is quite distinct from the Poterides and Senticoses by the fruit capsular with lateral styles and opening valvular. Gillenia, Aruncus, Thecanisia, Filipendula that are not frutescent will be iliustrated elsewhere and in my fl. tellur. I now propose to revise the shrubby Genera chiefly, which are Spirea, Physocarpa, Basilima, Śchizonotus and Epicostorus. The Monographs of Spirea by Smith in Rees, Poiret in Cycl. and Seringe in Decandole are by no means perfect even as to species and synonyms and I shall rectify them. I have verified many kinds by the figures of Pallas in flora Rossica, which had not always been properly applied and quoted. 
633. SPIREA Raf. calix 5fid persistent campanul. bearing on a glandular ring the 5 petals and stamens 20 to $\mathbf{3 0}$, Pistils 5 free sessile, styles lateral, 5 free capsules sessile equal opening inside oligosperm. Sthrubs with simple alternate leaves, flowers paniculate, thyrsoidal, branches racemose spicate or corymbose. The name ought to have been written Spiraia, it answers to the Subgenus Spirenia of Seringe. Chamedryon has umbellate or corymbose flowers.

634. Spirea tomentosa L. \&c. Dec. Beck. Stem angular nearly simple, rusty tomentose, leaves petiolate ovate lanceolate, acute at both ends, unequaly serrate, beneath white tomentose, panicle ample compound racemose, calix and capsules fuscate villose-This is the original sp. of Kalm, Lin. \&c found near Philadelphia and from New York to Carolina; but so many sp. have been blended with it, that nearly all the syncnyms apply to others. A small shrub 2 to 4 feet high, flowers purple handsome estival. Eaton had many var. of this in his first editions as myself in Med. flora, that are my next distinct deviations or Sp. the real var. are 1. albiflora, 2 eiatior. 3, ramosa with a few branches, and the next.

635. Spirea tomentosa, var. virgata Raf. (Elliot) Branches virgate rusty tomentose leaves rugose above, petals small hairy outside often trilobe-Hills of Carolina and Apalachian Mts. large 4-6feet, often ramose.

636. Spirea rosea Raf. diff. 634, leaves lanceolate remotely serrate acute, fulvous tomentose beneath, panicle lax, peduncles as long as calix-West Kentucky to Alabama, disc. by Mrs. Holley, a beautiful shrub with fine rosate 
flowers, it deserves to be deemed a peculiar sp. by narrow leaves not white beneath, and lax rose flowers.

637. Spirea feruginea Raf. stems angular simple fuscate tomentose, leaves oblong cuneate sessile, broadly serrate, beneath rusty tomentose, panicle ample foliose at the base, branches spicate, flowers subsessile, calix and capsules rusty rugose scabrous-East Kentucky, Mts. Wasioto and Apalachian, shrub 2 or 3 feet high, woody at base, flowers purple : easily known by the color, cuneate leaves, spikes and capsules. Var. angustifolia, leaves narrow cuneate, spikes slender. Pine barrens of New Jersey.

638. Spirea glomerata Raf. tomentosa Med. fl. tab. 88 stem simple terete sulcate fuscate tomentose, leaves petiolate elliptic or ovatoblong jagged serrate, beneath fulvous tomentose, panicle slender spicate, flowers subsessile glomerate, calix fulvous tomentose-Alleghany Mts. very small suffruticose pedal without branches, flowers small incarnate. Near to $\mathbf{S p}$. rosea, but different leaves, sessile flowers quite jagged or duplicate serrate, nankin color beneath. Var. 1 major, bipedal, 2 pallida.

639. Spirea glomerata var. cinerea Raf. differ. virgate, stem subterete not striate, ashy tomentose, leaves also beneath, and calix likewise-Pine barrens of New Jersey, pecal, flowers quite glomerate sessile redish.

640. Sprrea parvifolia Raf. Stem branched angular purplish smooth, branches tomentose, leaves sessile small elliptic base entire, serrate above, beneath grey tomentose, panicle spicate glomerate, flowers sessile, crowded, ca- 
lix and capsules grey tomentose-Canada, Laḱ Champlain, Saranac and Oquago Mts. a small ramose shrub pedal, flowers incarnate, leaves only half inch long.-All the above sp. agree in nothing but the tomentose leaves beneath, to deem them all varieties would be preposterous, as no character including them all could be framed; but they afford like the 8 blended sp. of $\mathbf{S}$. salicifolia, fine illustrations of real natural specific deviations, similar to those of the Genus Azalea! now admitted as species.

641. Spirea salicifolia L. Dec. \&c. Quite smooth, branches elongate terete yellowish, leaves subsessile broadly lanceolate equaly serrate, acute at both ends concolor, panicle racemose compound base foliose, bracts oblong. -In North Europe, Sibiria and Origon, my specimen is simple 2 feet long, leaves 3 inches long one wide, flowers white peduncled crowded. Five other American sp. have been blended with this by all the botanists, which altho' deviations perhaps are totally distinct from this: I have compared them all carefully and ascer. tained excellent peculiar characters in each, they only agree in having thin smooth leaves and the branches of the panicle nearly corymbose. Var. Sibirica Pallas fl. Ross. t. 21. differ branches yellowish, leaves unequaly serrate panicle lax not foliose, flowers large incarnate. Perhaps a peculiar species $\boldsymbol{S p}$. Sibirica Raf.

642. Spirea flexuosa Raf. salicif. of many Amer. bot. alba? Erhart. Mg. Quite smooth, branches flexuose angular redish, leaves petiolate oblong lanceol. deeply serrate, base entire cuneate pale beneath, panicle racemose base foliose, no bracts-Mts. Alleghanies and hills from Canada to Virginia, pretty shrub 2 to 4 
feet high, leaves only two inches long, flower s small white estival. If it is the sp. alba of $\mathrm{Er}$ hart it is also found in Sibiria.

643. Spirea aniena Raf. 1808. Quite smooth branches fuscate terete below angular above, leaves imbricate sessile oblong or elliptical sharply serrate,some obovate below, panicle racemose ovate naked.-From New Jersey to Kentucky, perhaps Origon and Sibiria, as I have received it also as Sibirian, similar to the last but distinct by stem flowers larger incarnate,no petiols and leaves smaller commonly uncial. Var. pauciflora, leaves oblong lanceolate or narrow elliptic serrulate, panicle capitate almost simple with few large pink flowers. Sibiria, this is Sp. salicifolia var. b. Pallas fl. ross. tab. 22. branches flexuose.

644. Spirea ovata Raf. Quite smooth, shoots simple virgate terete rugose purplish, leaves subsessile ovate acute imbricate deeply serrate or jagged, lower obovate, panicle racemose glomerate, base not foliose, some oblong bracts -Mts. Alleghanies, Wasioto and Apalachian, stems simple 1 or 2 feet high, only woody at base, leaves uncial or smaller, flowers white.

645. Spirea carpinifolia W. enum. Watson dendr. 66, Loudun Cycl. Quite smooth, leaves ovate elliptic acute at both ends coarsely serrate, panicle racemose spreading-Said to be from North America, flowers white, not seen, nearest to my Sp. ovata, stated by Muhlenberg to be the same as my Sp. corymbosi, but that is not paniculate; therefore a doubtful species.

646. Sproea heterophyla Raf. Quite smooth branches angular purplish, lower leaves rounded or lobed, medial obovate, upper elliptica!, 
all subpetiolate acute and sharply serrate, panicle racemose not foliose but with linear bracts -Alleghany Mts. and Alabama, 2 or $\mathbf{3}$ feet high ramose, leaves biuncial very broad, flowers white. A very distinct sp.

647. Spirea ciliata Raf. salicif. Elliot. Stem angular pubescent, leaves sessile imbricate consimilar cuneate acute, base entire, ciliate, sharply serrate upwards, panicle racemose glomerate elongate, bracts linear-From the River Wabash to Carolina near streams chiefly, a very peculiar sp. quite ciliolate, middle nerve often also, bipedal, leaves small uncial, flowers white Var. 1. petiolata, leaves subpetiol. broader, 2 multiflore panicle ramose.

648. Spirea obovata Raf. dec. 25. crenata Tor. Eat. Mg. hypericif. var Beck, chamedrif. Pursh. Quite smooth cespitose suffruticose creeping, branches flexuose angular redish, leaves similar obovate subsessile obtuse, base acute entire, upwards unequaly serrate, corymbs racemose terminal, bracteoles linear, petals obovate crenate undulate-Rocky summits of Mattawan and Kiskanom Mts. of New York disc. 1817, descr. 1818 in my decads, mistaken or omitted by all our botanists, probably a boreal plant. Shoots or branches assurgent woody only 4 to 16 inches high, leaves uncial concolor, panicle thyrsoidal ovate formed of small lateral corymbs, thus forming a passage to the subg. Chamedryon, flowers white blossoming in June. Having obtained specimens of the real Spir. crenata, ulmifolia and chamedrifolia I can vouch that this is quite different and no Chamedryon. Var. Sibirica of Pallas nameless fig. t. 26 f. 2, merely differ by narrow leaves nearly entire glaucous beneath. 
649. Spirea obacteata Raf. levigata? L. or of some botanists. Quite smooth, branches terete yellowish, leaves quite sessile oblong entire, base cuneate, apex obtuse cuspidate, some mixt ovate elliptic, panicle racemose, bracts ovate acute-Sibiria and New Sibiria, probably a large shrub, branches thick, leaves 2 or 4 inches long, one broad, base almost semiamplex. panicle compound, flowers white racemose. In my specimen some elliptical smaller leaves intermixt. Not quite answering to sp. levigata see below, yet sent me as such.

650. Spirea cuneifolia Raf. Herb. Quite smooth branches terete dark purple, leaves sessile cuneate entire, apex very obtuse cuspidate, panicles axillary and terminal racemose, bracts subulate-Origon and New Albion, a fine handsome shrub disc. by Walton, quite different from last by red flowers, small bracts and large leaves 3 to 6 inches long, quite cuneiform or tapering from end to base. The real Sp. levigata of Lin. is akin to both these sp. but it appears to differ by lanceolate glaucous less obtuse leaves and white flowers, (some botanists call the cuneate leaves lanceolate! which is the reverse tapering from base to end) while Smith blends the Sp. altaica with it, which I add for contrast.

651. Spirea altaica Pallas fl. ross. t. 23. Stem terete redish, leaves fasciculate sessile cuneate acute repand glaucous, racemes paniculate axillary and terminal, bracts lanceolate. -Altaic Mts. flowers white large, capsules large smooth 2 sperme, leaves 2 or 3 inches long, not cuspidate nor obtuse; thus quite different from the two last. Is it the real levigata of linneus as deemed by most of hotanists? 
65̃2. Spirea douglassi Hook. fi. Pubescent, leaves elliptic apex serrate, white hairy be. neath, panicle oblong, calix reflexed, capsules smooth-N. W. America, flowers small, near to Sp. tomentosa, no more different from it than my removed deviations.

653. Spirea menziesi Hook. fl. differs from last only by leaves smooth beneath, yet made a species by Hooker.

Subgenus Chamedryon Ser. Dec. only difference flowers umbellate or corymbose, calix often nervose or venose.

654. Spirea (Ch.) chamedrifolia L. Jaq. and Europe. Smooth, branches cinereous su. bangular, leaves petiolate obovate entire obtuse base acute or unequaly repand lobed or jagged near the end, racemes terminal simple corymbose, pedicels filiform lax-Carpathian and other European Mts. many short branchlets, leaves small thin uncial, flowers really in a corymbose racemes, the lower having long slender pedicels, petals white rounded. My description is original from a specimen of Jacquin, introduced here to compare it with the blended kinds.

655. Spirea (Ch.) versifolia Raf. chamedrif. Pallas ft. t. 15. Sm. Hooker fl. bor. \&c. Smooth, branches terete redish, leaves petiolate acute at both ends ovate serrate, base entire, the lower duplicate serrate ovate lanceol. flowers subumbellate-Sibiria and New Sibiria, flowers white. almost in umbels since pedicels fasciculate, thus distinct from the last, and leaves quite unlike; but Pallas says the leaves are variable, probably many species are even klended here, one of which 1 can ascertain. 
656. Spirea (Ch.) laurica Raf. chamedrif. Var. Pallas t. 15. differs by leaves elliptic pubescent nearly entire, crenate above, tomentose beneath-Daurian Mts. of Sibiria, nearer to Sp. douglassi than the Sp. versifolia, but flowers not paniculate.

65\%. Spirea (Ch.) ulmifolia Scop. t. 22. W. P. Sm. chamedrif. Amman Lind. b. reg. 1222 ! Smooth, branches slender flexuose angular, leaves petiolate ovate laciniate serrate acute, base entire subacute, flowers terminal corymbose crowded, pedicels filiform often with a subulate bract-Mts. of Europe and Sibiria, my specimen is an original one of Scopoli from Carniolia, and agrees perfectly with the figure of Lindley with mistaken name : totaly different from Sp. chamedrif. leaves and flowers larger.

658. Spirea (Ch.) betulifolia Pallas fl. t, 16. not Pursh. Smooth, shrubby branches terete redish, leaves subsessile ovate rounded laciniate serrate, yellow beneath, flowers terminal corymbose lax-Sibiria and New Sibiria? flowers white.

659. Spirea (Ch.] ostryfolia Raf. betulifolia Pursh not Pallas. Suffruticose, quite smooth, shoots terete redish, leaves petiolate acute at both ends ovatoblong laciniate serrate except at the base, apex often obliqual, glaucous beneath, corymb. pauciflore simple foliose crowded-Alleghany Mts. of Virginia found there 1825, intermediate between the last and the next, semipedal, leaves 2 inches long quite thin, flowers white. Var. pumila, 4 inches high flexuose few leaves the lowest large duplicate serrate, corymb glomerate, Wasioto Mts. 
660. Spirea (Ch.) corymbosa Raf. 1804, precis 1814, Mg. 1812, 1818. Lod. cab. (or sp. glauca Raf.) carpinifolia? W. Suffruticose quite smooth, stem angular redish, leaves petiolate ovatoblong acute at both ends, unequaly serrate entire at the base, quite glaucous almost white beneath, corymb terminal multiflore compound subfoliose each peduncled crowded - Alleghanies of Pennsylv. Maryland and Virginia on dry ridges, stems pedal often annual leaves 1 or 2 inches long, nerves prominent beneath, flowers white in large multiflore corymbs with 1 to 3 small ovate entire leaves, flowers nearly level large, stamens long. By a misprint I stated this sp. to be trigynous in my precis 1815, it is 5gynous. I discovered this plant in 1804 and communicated it to Muhlenberg. Sp. glauca would be a better name as there are so many corymbose kinds.

661. Spirea (Ch.) repens Raf. corymbosa Torrey, Beck, Eaton \&c. Stems suffruticose creeping, shoots tereto redish erect, leaves sessile smooth variable obovate oblong and ovate, obtuse or acute, unequaly serrate, base entire, pale beneath, corymb terminal compound compact fastigiate subfoliose, stamens elon ate.Lake Champlain, Mts. Saranac and Oquago, shoots 4 to 6 inches long, leaves uncial, flowers small pale incarnate. Var. pubescens, leaves oblong obovate pubescent beneath, stem pedal and flowers pale rose color. Thi ; is the Sp. corymbosa of the above Authors, said to be pubescent. My specimens are all glabrous. Do they mean the next species?

662. Spirea (Ch.) crenata L. Bar. t. 564. Smith hypericif. var. crenata Dec. not Beck. 
Puberulent or pulverulent, branches angular purplish, leaves petiolate glaucous cuneate entire or apex crenate dentate obtuse, base acute, smooth above, trinerve and puberulent beneath, corymbs terminal on branchlets pauciflore subumbellate, stamens very short-Europe from Spain to Hungary; my specimen is fiom Hungary, with branches ramose not virgate, leaves small semiuncial, flowers white, corymbs 5-7 flore, pedicels puberulent sometimes with a subulate bract. This Linnean sp. is not American, Hooker has it not, Smith has proved that several sp. were blended, the Sibirian is my next. Even Linneus in taking barrelier's plant as type, mistook others for it and called the leaves ovatoblong, he meant obovate oblong. The name being equivocal and liable to objections, might be changed to $S p$. pulverulenta Raf.

663. Spirea (Ch.) denticulata Raf. crenata Pallas. ff. t. 19. Wild. Pers. \&c. Smooth, branches yellowish, leaves sessile obovate or cuneate denticulate acute upwards, beneath glaucous, lower leaves petiolate ovate denticulate, corymbs lateral pauciflore-Sibiria and probably New Sibiria, flowers white ; even Pallas speaks of some varieties, one with laciniate trinerve leaves may be a distinct sp.laciniata? Raf.

664. Spirea (Ch.) Japonica Raf. crenata Thunb. fl. Smooth, branches virgate, leaves petiolate lanceol. hardly serrate, flowers umbellate, calix campan. deeply 5 fid. petals emarginate-in Japan, called there Awaju, another mistaken reference to $\mathrm{Sp}$. crenata, quite distinct from all, nearer to the next by the umbels. 
665. Spirea (Ch.) italica or Reticulata Raf. hypericifolia Sm. and many Authors, type in Bocc. mus. t. 96. Quite smooth, branches angular purplish, leaves sessile cuneate entire obtuse concolor, beneath nerves reticulate, flowers in small pauciflore umbels sessile at the end of branchlets, calix venose, each segments ovate with 3 veins-Native of the hills of Umbria in Italy where discovered by Bocconi, and again by Sir James Smith see Rees Cycl. it has become common in gardens, where it is blended with the next, and botanists have been perplexed for its locality: hypericifolia having become equivocal ought to be changed as I propose. Leaves small semiuncial 'not glaucons nor trinerve, but slightly trinervate sometimes, umbels of 3 to 7 tlowers, petals white obovate.

666. Spirea (Ch.) virgata Raf. hypericifolia of Lin and many botanists, hyper. var. plukenetiana Dec. Hooker, Beck. Pluk. alm. 218. 5-Branches fuscate angular rugose virgate, leaves sessile cuneate obtuse or retuse, entire smooth above, pubescent and glaucous beneath, nerves with paralel branches not reticulate, umbels pauciflore lateral subsessile foliose at base, pedicels angular, calix decangular at base, segments uninerve.-This is the real American Species, so long deemed doubtful, native of boreal America and New Sibiria, common in our gardens ; flowers vernal in white umbels almost sessile at first, but peduncled and foliose as the leaves unfold, these are small semiuncial nearly similar to the last in shape and size, but thicker and quite different beneath, the calix is very peculiar by its 10 angles or nerves. Var. hookeriana Raf. Leaves stmooth entire, umbels corymbose sessile, of N. W. America is proba- 
bly a peculiar species near to my Sp. crenata, as it cannot be Sp. italica! It must be boiter described, and may be called Sp. hookeriana R. It is akin to Sp. japonica. I hope to have thus ascertained many obscure or lost species, and elucidated the whole genus; in order to remove the difficulties I have been compelled to introduce some species not strictly American, but have greatly increased ours also. 'This will conclude the true G. Spirea, I shall now describe the akin blended Genera.

667. PHYSOCARPA Raf. subg. of Ser. (or Physotheca.) Diff. Spirea, calix deeply 5fid, pistils 3 united at base, capsules 3 coalescent swelled smooth, apex free bivalve, leaves lobed, flowers in short corymbose racemes bracteated-Thus it differs as much as Gillenia but has not a tubular calix.

668. Physoc. Riparia Raf. Spirea opulifolia L. \&oc. Var. tomentella Dec. Beck. Branches angular pale, leaves petiolate ovate rounded or oblong unequaly serrate often lobed or trifid acute quite smooth, beneath pale trinervate, corymbs terminal, bracts oblong or laciniate, pedicles filiform pubescent, calix tomentose acute, capsules smooth much swelled-From Canada to Carolina, Louisiana and Missouri, on the banks of streams. Shrub 5 to 10 feet high, leaves 2 or 3 inches long, flowers white with pink shades, capsules fulvous or fuscate, seeds rounded yellowish. This has always been deemed the Sp. opulifolia by our botanists, and it was really that of Linneus, since he gives America as its only locality; but now many others must be separated. Var. 1. parrifolia, 2. arborea.

669. Physoc. opulifolia or glabra Raf. Sp. 
opulif. Dec. and many botanists. Var. glabra Hooker. Quite smooth, branches angular cinereous, leaves ovate trilobe, petiolate, dentate or crenate, corymbs terminal, bracts ovatoblong pedicels smooth, calix smooth obtuse, capsules smooth compressed at the end-Mts. of East Europe, Sibiria and Origon. Very distinct from the last by many characters, entitled to be a species, seeds obovate yellow.

670. Puysoc. tounerosa Raf. Sp. capitata Pursh, Eat. Sp. opulif. var. tomentosa Hook. fi. Leaves ovate sublobate, doubly dentate, reticulate and tomentose beneath, corymbs terminal crowded subcapitate on a long peduncle, calix tomentose-Origon, another distinct sp. blended by Hooker, altho' distinguished by Pursh and others. The Sp. monogyna of Torrey is also reduced to Sip. opulif. by Hooker, while it is even a peculiar Genus! See the next.

671. EPICUS TORUS Raf. atl.J. page 144. Sp. monogyna Tor. rocky mts. 119. Eaton $\mathcal{\&} \cdot \mathrm{c}$, Sp. opul. var. monogyna! Hook. fl. Calix campanul. 5iobed, petals 5, stamens 20 inserted on a circular free torus or base monadelphous, pistils 1 or 2 stipitate, with a style,capitate stigma, capsules 1 or 2 compressed not swelled free villose bivalve trisperme. Ilabit of Physocarpa, pedicels few, no bracts.-EPIC. MONTAnus $R$ af. as above. Leaves rounded ovate base subcordate, subtrilobe, incise, dentate pubescent beneath, corymbs on short peduncles pauciflore, pedicels filiform calix obtuse pubescent -in the Origon mts. disc. by James, descr. by 'Torrey 182\%, mistaken by Hooker since, ascertained by me in 1832 , the generic name means 20 on a torus.

672. SCHIZONO'TUS Raf. calix rotate 
deeply 5 fid colorate villose, petals 5 equal venose, stamens 20 inserted on a torus adnate to the base of calix, pistils 5 equal sessile, capsules 5 sessile tomentose monospern. Habit of the paniculate Spircas. I have adopted this Genus and name on the suggestion of Lindley, who proposed to unite to it the next, but the habit is too difierent. Schizonotus appears to mean Split back and I do not know how it applies unless the capsules open outside.

673. Schizonotus viscolor Raf. Spirea do Pursh, Torrey Dec. ariafolia Sm. Hook. Lind. b. reg. 1365. Leaves petiolate ovatoblong sublobate and laciniate serrate, white villose beneath, flowers terminal paniculate racemose, pedicels and calix villose, petals oblong with 3 veins-Origon region and Mts. A very peculiar shrub, quite different from my Thecanisia discolor 29\%, to which I refered by mistake the Sp. discolor of Pursh, flowers white, leaves called elliptic by Smith, ovate by Pursh and Torrey but they are realy ovate oblong.

674. BASILIMA Raf. 1815. Sorbaria subg. Ser. Schizonotus Iind. Cal. patent 5parted smooth not colorate, base acute, petals 5 , stamens 15 to 20 inserted at the base of the calix, pistils 4 to 5 sessile, capsules 4 to 5 unequal sessile smooth monosperm. Large shrubs with the foliage of Roses and Sorbus, leaves alternate stipulate oddly pinnaic, folioles opposite sessile, flowers bracteolaie paniculate or corymbose-This fine natural Genus is certainly more different from Spirea than Lowea is from Rosa! it may be known at first sight by its habit.

675. Basilma sombiroma Raf. Sp. do L. \&c. Pallas fl. t. 24. Quite smooth, branches 
terete flexuose, leaves with 11 to 21 folioles broad lanceol. acuminate duplicate serrate, stipules oblong entire, flowers paniculate crowded, panicle oblong, bracteoles lanceol. equal to the short clavate pedicels-Sibiria and New Sibiria in N. W. America, a large shrub, with fine incarnate odorous flowers, folioles 1 or 2 inches long. My specimens have racemose panicles before anthesis, becoming glomerate in full bloom.

676. Basilima pygmea Raf. Sp. sorbif. var. pygmea Pallas fl. t. 25. Quite different from the last by folioles broader less acum. ovate lanceol. laciniate and flowers corymbose-Mts. of Sibiria and probably in boreal America, a small dwarf shrub. Not seen but the figure of Pallas is strikingly different. It must not be blended with the Sorbus pumila of Origon, that has edible berries.

\section{Monograph of HYDRANGEA.}

Linneus had only one species, our botanists have gradualy increased them to 4 ; but I shall still further increase them to 10. They are all shrubs growing in mountains and hills on rocks and near streams, blossoms estival. The Genus had been united to the Saxifragides, but Lindley dreamt that it was to be united to the Caprifoliacea! with berries and monopetal corollas! It really belongs to the Natural family of Diceracen in the Nat. Order Ascadia, which includes all the Saxifragides with ovary and capsule coalescent or inferior. It includes two subgenera.

Apleria. Flowers uniform consimilar.

Meg.asteira. Flowers dissimilar, the exterior enlarged neutral radial, as in Opulus, 3-4fid unequal. 
The habit is peculiar, leaves opposite petiolate, flowers terminal cymose or paniculate. It is therefore a natural Genus, having affinities with the Myrtoides, Hederacea and Viburnides. The G. Itea and Cunonia differ by free pistil.

677. Hydrangea (Apl.) vulgairis Mx. P. B. E. \&c arborescens L. \&c. Branches terete sulcate pale, leaves ovatoblong acuminate, equaly serrate smooth pale beneath, petiols and nerves pubescent, base rounded, cymes naked pubescent uniform, 2 oblong bracts-Alleghany Mts. and hills from Pennsylv. to Carolina and Kentucky, $\boldsymbol{B}$ to 5 feet high, leaves 2 or 3 inches long, flowers white and small. Var. carnea, flowers incarnate.

678. Hydr. (Apl.) Paniculata Raf. Quite smooth, branches terete fuscate, leaves ovatoblong both ends acute, glaucous on both sides, nearly entire or remotely dentate, cyme paniculate lax with oblong sessile bracts- $\mathbf{A}$ very distinct Sp. found without locality in Collins herb. probably from Origon and Sibiria, leaves large 4 inches long 2 wide, petiols shorter uncial slightly ciliolate, flowers much larger than in the last, with large lanceolate petals, calix angular, stamens erect longer than petals.

679. Hydrangea (Meg.) acuta Raf. Branches sub angular purplish, leaves ovatoblong unequaly serrate, acuminate, base acute entire, pale beneath, nerves puberulent, cymes pubescent naked hardly radiate, bracts small ovateApalachian Mts. Leaves very thin, cymes small, commonly with 1 to 3 small neutral flowers unequaly trifid acute white. Thus a passage to the subgenus Megasteira.

680. Hydr. (Meg.) glauca Raf. radiata glau- 
ca Mg. Branches terete biangular, leaves ovate serrate acuin. base rounded, beneath glaucous smooth, upper leaves subsessile, cymes radiate, neutral rays 3-4fid-Alabama and Alloghanies, leaves thin large, flowers white, rays with unequal rounded segments. Capsules as in most species with 10 prominent nerves.

681. Hydr. (Meg.) notundifolia Raf. Branches angular rough, lower leaves petiolate rounded and orbicular acum. serrate, base not cordate, rough above, pale beneath, nerrs rough pubescent, upper leaves sessile ovate base acute, cymes radiate, rays 3 -4fid large rounded obtuse.-Wasioto Mts. of Kentucliy and Virginia on rocks, 3 to 4 feet high, leaves small, flowers large white, rays very large urequal.

682. Hydr. (Meg.) neterophyla Raf. Branches subangular, leaves elliptic, base cor date or truncate or obliquate, apex acumin. falcate, unequaly serrate, beneath concolor nerves puberulent, upper leaves rounded base rounded, cymes hardly radiate pubescent, rays ovate acute.-Wasioto Mis. of Kentucky disc. 1823 with the last, akin but distinct by leaves and rays, these sometimes lacking.

6S3. Hydr. (Meg.) cordata Pursh. E. \&c. Branches angular,leaves firm rounded base subcordate, dentate shortly acuminate, rough above beneath concolor veins reticulate smooth, cymes radiate, rays many ovate acute, 2 oblong bracts -Virginia, Carolina, Kentucky \&c on rocks, humble shrub 2 to 4 feet high, with larger thicker leaves, and ample cymes.

681. Hydr. (Mog.) anplifolia Raf. Branches subangular leaves on very long petiols thin ample ovate, lower subcordate at base, smooth 
acumin. laciniate serrate pale beneath, cymes hardly radiate, bracts oblong-Banks of the Delaware and Susquehannah in Mts. Alleghanies, a large shrub $\mathbf{6}$ to $\mathbf{1 0}$ feet high, leaves very large 5 to 8 inches long, petiols 3 to 5 inches, cymes ample, only 1 or 2 neutral rays.

685. Hydr. (Meg.) discoror Raf. Branches angular, leaves elliptic acumin. base often acute serrulate, beneath whitish closely tomentose, cyme villose subradiate, bracts 2 lanceol. falcate sessile, rays small obovate acute-Apalachian Mts. often blended with the next probably, but distinct by leaves and rays, shrub 6 to 10 feet high, seen alive in gardens.

686. Hydr. (Meg.) nivea Mx. P. E. ofc. radiata Walter. Branches terete dark purple, leaves firm ovate acum. base subcordate, serrate, rugose above and pubescent along the nerves, beneath snowy white tomentose, cymes subradiate, rays lanceolate-Apalachian and Unaka Mts. on the R. Santi \& c, elegant shrub, well described by Elliot, my specimens are but slightly cordate, flowers white late vornal.

687. Hynr. (Meg.) quercifola Bartr. trav. ic. Pursh, E. $\mathcal{S}$ c. A well known shrub, now common in our gardens, found by Bartram in the Cheroki mts. 60 years ago, published and figured in his travels 45 years ago, yect omitted by Wild. Pers. and all till Pursh? Easily known by the lobate leaves and large thyrsoid panicle of pink flowers many neutrals. Bartram says it grows on the $\mathbf{R}$. Oconi and in North Alabama near streams, has many divergent stems 5 to 6 feet high, the bark peals as in Physocarpa, the broad oboval neutral flowers are at first rosate, but gradualy change to red, purple, rusty and brown. 


\section{FAGUS and CASTANEA.}

The Beech and Chesnut trees so unlike and easily known by their fruits had been kept separate by the old Botanists, but Linneus took the fancy to unite them under his Fagus.-This linnean blunder was never assented to by the French Botanists, and now after 100 years the two genera are again acknowledged. But as to our American Sp. they are yet miscalled and deemed the same as the European; which is erroneous, none of our trees being quite identic! I must therefore revise them and add some new kinds.

688. Fagus Alba Raf. sylvatica of Amer. bot. not L. nor Europe. Bark smooth white, branchlets terete cinereous, leaves on short petiols ovate lanceol. dentate ciliate, acute at both ends, green concolor, aments on short peduncles, nuts ovate mucronate obtusely trigone -Our white Beech tree, common all over $\mathrm{N}$. America, 50 to 60 feet high, leaves 2 or 3 inches long. Dioical or polygamous.

689. Fagus heterophyla Raf. Bark and branches grey, branchlets terete, leaves subpetiolate ovate obovate rhomboidal and elliptic, acute at both ends, remotely uncinate serrulate above, sometimes jagged on one side, margin and nerves pilose, surface yellowish green concolor, aments on long filiform pilose peduncles, nuts ovate angles obtuse-Our Grey Beech is a rare tree, smaller than the last, occasionaly met in the dry hills of the Alleghanies, leaves thin about biuncial of a yellowish cast, quite entire till the middle then serrulate and subacuminate.

690. Fagus ferruginea Ait. purpurea of 
some botanists. Bark redish, branchlets terete sulcate dark purple, leaves subpetiolate ovatoblong remotely serrate acuminate, base acute or obtuse often obliqual, margin ciliate, young nerves pilose, surface rusty, pale berieath, aments on thick peduncles, nuts ovate acute with sharp angles-our Red Beech is found from New England to Missouri, the wood has a redish tinge like the bark, leaves 2 or 3 inches long, monoical, female flowers with many linear smooth bracts. A large tree $\mathbf{5 0}$ to $\mathbf{1 0 0}$ feet high.

691. Fagus nigra Raf. Bark fuscate, branchlets blackish terete sulcate, leaves subsessile ample ovate rhomboidal, acumin. base acute, margin denticulate, surface dark green glossy on both sides, nuts acute angles sharp-This tree called Black or Brown Beech is sparingly found with the others, 40 to 70 feet high, branches so dark purple as to be almost black, leaves very large 4 to 5 inches long.

692. Fagus rotundifolia Raf. fl. tex. 10 atl. J. 177. Bark fuscate, branchlets terete fuscate, leaves petiolate rounded repand acute, petiols margins and nerves above and beneath silky pilose, aments commonly geminate on short and thick peduncles silky like the bracts -A very distinct Sp. first described by me in 1833, it appears to have an extensive range, it first appears in Arkanzas and Texas, extending to Origon and Sibiria, perhaps even to Europe, where several blended Sp. exist which I shall shortly notice for contrast with ours. This Beech tree is smaller than the others 20 to 30 feet high, leaves 1 or 2 inches long and broad. It may be called the Silky Beech.

693. Fagus sylvatica L. \&c. Branches 
diffuse fuscate, leaves petiolate ovate acute subserrate undulate, smooth glossy yellowish, margin villose, peduncles filiform villose, nuts ovate angles obtuse-Europe and Sibiria. Var. sanguinea leaves red.

694. Fagus asplenifolia Raf. Leaves ovate serrate laciniate or lanceolate lobulate-Europe and Sibiria, a small tree.

695. Castanea vesca W. P. Dec. \&c. Fa-

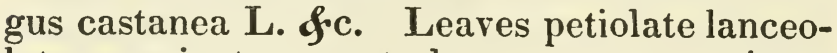
late acuminate, serrate by mucronate uncinate teeth, smooth beneath, capsules echinate disperme, nuts large dimidiate smooth mealy inside-South of Europe, very large tree, nuts 4 times as large as ours, darker, farinaceous not oily, one side flat, the other convex.

696. Castanea americana Raf. 1804. vesca var. amer. W. P. and the Amer. botanists. Branchlets fuscate rugose, leaves petiolate oblong lanceol. acum. remotely mucronate serrate, beneath glaucous and smooth (pubescent in young leaves, aments fasciculate spicate interrupted glomerate, capsules echinate 3-5seeded, nuts small ovate apex villose acute, corylaceous sweet inside-All over North Ámerica from Canada to Louisiana and Origon, quite a peculiar Sp. ascertained by me since 1804 in my fl. columbica. A smaller tree than the European only 40 to 60 feet high, growing in dry and rocky ridges and Mts. leaves 4 to 8 inches long, fruits quite unlike the European Chesnuts, small similar to filberds in size and taste, sweet oily, and edible raw, while the European must be boiled or roasted being acerb. Nuttal has well described the fructification. Var. 1. ANgustifolia Raf. Leaves very long and narrow 
lanceolate, on the Susquehanah. 2 Var.latifolia. Leaves broader and shorter, rather acute than acum. High Mts. a small tree. Perhaps these are two incipient Sp. I regret that I did not see the fiuits.

697. Castanea pumila of late Authors, Fagus do L. \&c, our well known Chincapin nut, edible sweet, from Delaware to Florida. Var. fulva Raf. Leaves broader often nearly obovate, almost fulvous beneath, nerves quite so, aments compact. Alleghany Mis.

698. Castanea nana Mg. El. Eat. alnifolia Nut. a small shrub 2 or 3 feet high with ovate lanceol. leaves, almost obtuse, subtomentose beneath, capsules monosperm-Carolina to Florida, in sandy tracts, creeping.

699. CLADRASTIS Raf. fl. Kent. 1824, Neog. 1825. Virgilia Sp. Mx. and others. Calix gibbose campan. unequaly 5̆lobed, petals $\mathbf{5}$ unequal unguiculate, superior larger obovate notched, 4 oblong obtuse subcordate at base. Stamens 10 fiee unequal filiform, pistil stipitate oblong, style curved compressed, stigma acute. Pod stipitate linear flat membranaceous polysperm, seeds oblong. Trees with odly pinnate leaves and racemose white flowers, without bracts. As soon as I found this tree in Kentucky in 1821 I ascertained that it was not congeneric with the African Virgilias which have calix bilabiate, 2 of the petals cariniform, stigma obtuse, seeds lenticular \&c. The name means brittle branches.

700. Cladrastis tinctoria (or albiflora) Raf. Virgilia lutea Mx. ic. Nut. Eat. Dec. Kentukensis Dumont. Smooth tree, Leaves 5-7folioles petiolate alternate ovate acumin. entire, glaucous beneath, the odd larger ovate 
rhomboidal, base acute, flowers in simple lax nodding racemes, white odorous, pods smooth. -From Kentucky to Alabama, but very local, a fine tree 30 to 50 feet high, branches brittle, wood branches petiols and nerves yellow, leaves ample, folioles 3 to 6 inches long very smooth. Flowers white fragrant like those of Robinia, not yellow as stated by Nuttal and after him by many, even Decandole! Michaux does not say so, in his colored trees they are white, his improper name lutea applied to the wood not the flowers, Nuttal did not see the flowers and mistook his meaning. 1 have seen them! 'The wood is yellow and dies yellow like Fustic. The vulgar names are yellow wood and yellow Locust. The V. Kentukensis of Dumont Courset (Botaniste cultivateur) is only the young tree before blooming. It blossoms only in May for one week on the banks of the River Kentucky. I shall add two other new Genera rather akin but with yellow and blue flowers. They all belong to the Leguminose, suborder Lomentaria with free stamens, and natural family of Sophorides.

701. ZANTHYRSIS Raf. calix persistent campanul. equaly 5 dentate, petals $\mathbf{5}$ subequal cuneate obtuse, 1 narrower, 10 stamens subequal, pistil stipitate, podogyne villose longer than calix, ovary smooth terete curved, style very short, stigma acute, pod stipitate podogyne tomentose, pod falcate subterete, seeds .. Tree with odly pinnate leaves, no bracts, thyrsoidal yellow flowers-This Genus is nearer Sophora than the last, but has some very peculiar characters, the name applies to the yellow thyrsus.

702. Zanthyrsis paniculata Raf. Virgilia 
aurea Collins herb. not of Authors. Branches fuscate subangular and puberulent, leaves with many folioles sessile oblong obtuse nearly smooth concolor, petiols pubescent, panicle terminal foliose lax, peduncles 2-3flore-South Florida and Cuba, a small tree, habit and leaves like Amorpha and Virgilia, folioles 21 to 25 half uncial. Flowers in a lax compound raceme forming a panicled thyrsus, small and yellow, half size of Cladrastis. The podogyne is very remarkable by its length and white hairs. I add for contrast the real Virgilia aurea of Africa.

703. Virgilia aurea Lam. t. 326. f. 1. Wild. Pers. Poiret Sm. Dec. Shrub, leaves with many folioles petiolate elliptic obtuse smooth glaucous beneath, raceme simple with small lanceolate bracts, pods shortly stipitate oblong compressed reticulate, seeds lenticular -In Abyssinia in East Africa! thus totaly unlike our American plant and having the character's of the African Virgilias, calix bilabiate, petals unequal, 2 cariniform, a short smooth stipes to the pod. Flowers golden, called white by mistake in Poiret.

704. AGASTIANIS Raf. Virgilia, Sophora, and Broussonetia! of Authors. Calix bilabiate, lips 2 and 3 dentate, petals 5 unequal, vexillum oval emarginate larger, 4 oblong biauriculate at base, 2 connivent cariniform. Stam. 10 unequal free persistent, pistil terete shortly stipitate, a style, stigma obtuse. Pod oblong tomentose convex on both sides. Sthrub with odly pinnate leaves, flowers blue in simple racemes with bracts - This fine shrub has been shuffled in several Genera, I deemed it myself 
a Cladrastis in 1825, but am now convinced that it is realy a peculiar Genus as deemed by Ortega; but his name of Broussonetia had been employed, mine means remarkable blue.

705. Agastianis secundiflora Raf. Broussonetia do. Ort. dec. 7. Virgilia do. Cav.t. 401. Pers. Sm. Sophora do. Dec. Branches angular, leaves with 11-15folioles subsessile oval smooth rigid, petiols swelled at base, racemes tomentose secundiflore, pedicels with 3 bracts, 1 at base, 2 beneath the calix-Mexico and Texas, a pretty shrub with handsome blue flowers, the vexillum or large petal pale blue. Decandole says the pods are moniliform as in Sophora, but he did not see them: even if they are the calix and petals are different from the real Sophoras, still more so from those with 4 gone or monosperm pods that must form the Genera Gonondra and Aplenda Raf. 1815, and fl. tel.

Monograph of CHIONANTHUS.

This Genus of the Fraxinides family is very near to the Ornanthes, differing only by a drupe for fruit and simple leaves. Linneus had only Ch. Virginica of N. Amer. some presumed varieties were since noticed, but $\mathbf{I}$ have been able to ascertain 6 species qnite distinct, although forming a very natural Genus; called vulgary Fringe trees: they are all small trees, with handsome panicles of vernal white flowers, and opposite leaves quite entire. The Sp. of South America and Ceylon \&c must be examined again and will probably form peculiar subgenera if not Genera. Mayepea, Linociera and Thouinia must be restored. All our Sp. have a small 4 fid calix, 4 linear petals and 2 stamens not 4 as Mayepea.

706. Chionantuus maritima Raf. Virg. L. 
\&c. var. marit. Pursh Eat. Beck. Branches terete fuscate pubescent, leaves petiolato obovate elliptical membranaceous obtuse or acute pubescent beneath, panicles multiflore lax, bracts ovate and oblong, peduncles mostly triflore, calix unequal, fruits elliptical purple-A small tree 10 to 30 feet high, growing near the sea shores or near streams of the littoral region from New Jersey to Florida, leaves 3 to 4 inches long, commonly obovate, sometimes elliptical, panicles with many large flowers. Var. rhombifolia Raf. leaves elliptic rhomboidal, base acute, end obtuse, bracts lanceolate. In Delaware,

707. Chion. obovata Raf. domingensis? Lam. Quite smooth, branches terete whitish with round warts, leaves subsessile obovate rounded, base acuminate, apex very obtuse, panicles cymose pauciflore lax, peduncles biflore rigid divergent, bracts obovate sessile, calix unequal, fruits ovate acute-Hills of Alabama, large leaves 4 to 6 inches long, quite round at the end, firmer and broader than in the last, fewer flowers. Probably also found in the Antilles and Florida.

708. Chion. heterophyla Raf. virginica Mx. Leaves petiolate obovate acute or elliptic acuminate or ovate lanceolate pubescent beneath, nerves rufous, panicles lax pauciflore, bracts sessile ovate or oblong, peduncles 1-3 flore, calix subequal, fruits ovate subacute-Apalachian and Wasioto Mts. medial between Ch. maritima and montana.

709. Chron. montana Raf. virg. L. var. mont. P. B. E. Branches smooth pale 4angular rugose with oblong warts, leaves firm sub- 
sessile ovate lanceol. acute at both ends, glaucous beneath and smooth, nerves fuscate hardly puberulent, panicles multiflore compact, peduncles triflore, bracts ovate or oblong, calix equal, fruits oval.-Alleghany and Apalachian Mts. from Virginia to Georgia, a small tree 4 to 10 feet high, leaves 3 to 4 inches long. The warts are singular oblong with a fissure.

710. Chion. longifolia Raf. Branches subangular pubescent fuscate, leaves subpetiolate, oblong lanceol. undulate acum. at both ends, nerves fuscate pubescent, racemes simple elongate pauciflore lax pubescent bracts elliptic, peduncles filiform 1-2flore, calix equal-Louisiana and Texas, leaves 6 to 8 inches long, about 2 wide, flowers rather smaller than in the others : fruits not seen.

711. Chion. angustifolia Raf. virginica? Elliot. virg. angustif. Ait. Quite smooth, branches pale subangular with flat ringed warts, leaves petiolate lanceolate acute or acuminate glaucous beneath, panicles lax pauciflore, bracts ovatoblong, peduncles mostly triflore, calix subequal elongate-Carolina and Florida, a very distinct Sp. by leaves very narrow, 3 to 4 inches long, but hardly one broad, flowers small, fruits globular. Very peculiar warts on the stem round flat with a circular concentric furrow. Shrub 3 to 10 feet high (Elliot.) Var. cylindrica Elliot, with long cylindrical multiflore panicles.

712. FORESTIERA Poiret 1811, Bigelowia Smith 1821 not of Raf. 1817. Adelia Brown and Michaux not of Lin. Borya of Wildenow and Persoon, not of Labilardiere and Poiret. See my article Adelia in first part; 
I have since ascertained that Forestiera was the first unemployed name given to this Genus by Poiret, and must be adopted by all correct Botanists! 'Ihis Genus thus made ambiguous in name is also somewhat doubtful in characters, because the dioical flowers are difficult to examine: it contains probably many species as these shrubs are unnoticed unless met in bloom. They are very near to Fraxinus by the flowers, and Chionanthus by the fruit, and simple opposite leaves: Thus evidently of the same natural family. But like Fraxinus they include several subgenera, that ought perhaps to be Gencra, and I will consider them as such in order to distinguish them better.

713. Forestiera Poir. Raf. Dioical, calix 4 parted persistent, 2 or 3 anthers on a single central filament. fem. fl. calix 2 or 4 parted unequal,no corolla. one pistil with style and bilobe stigma. Fruit a berry drupaceous one seeded, seed cartilaginous sulcate or rugose. Shrubs with commonly entire opposite leaves and lateral sessile flowers. 'I'his includes most of the species; but they must all be examined again, in bloom.

714. CARPOXIS Raf. (sharp fiuit) Polygamous? Calix 4parted Stamens 4 inserted in the calix (Elliot,) calix with a 5th smaller segment outside and more than 4 stamens, each on a flament. Fem. fl. ternate on fascicled peduncles, no calix, pistil oblong, no style, stigma sessile acute. Drupaceous berry oblong acuminate, seed sulcate. Shrubs often thorny, leaves ofc as in Foresticra. I have followed the figure of Michaux which shows almost a polyandrous flower? and the whole quite different from the others. Elliot justly doubts the 
genus of his Shrub ; it must be evidently a peculiar one near to Nudilus and some Ilexides to be compared, as well as my Genus Nestronia 503.

715. NUDILUS Raf. ft. tex. 1. in Atl. J. 176 and Herb. Raf. Dioical, male fl .... fem. fi. no calix nor corolla, pistil ovate, a long style, stigma capitate. Drupaceous berry ovate one seeded. Shrubs with opposite or subalterne leaves, flowers lateral peduncled. This is the only Genus I have been able to examine alive, and I only met the female flowers, which have really no calix as in some Fraxinides, whence the name of Nudilus. I shall now enumerate 12 species belonging to those 3 Genera, altho' our botanists have only 3 or 4, Elliot and Eaton only two.

716. Forestiera ligustrina Poiret, Adelia, Borya, Bigelowia of Authors. I Leaves thin subpetiolate lanceolate oblong entire, fruits ovate -In Illinois and Tennessee, habit of Ligustrum, only found by Michaux, not in Elliot nor Eaton, not seen by me.

717. Forestiera disticha (or heterophyla) Raf. Borya distichophyla of Nuttal. Quite smooth, branches divergent subterete levigate grey, leaves distichal subsessile thin entire, margin scabrous, uninerve, the lower ovate, the upper lanceolate or oblong acute, bud scales acuminate pungent-found by Nuttall in East Tennessee on the banks of Frenchbroad River. My specimen is from him in Collins Herb. A tall shrub 12 to 16 feet high, leaves small uncial or less. Flowers and fruits not seen.

718. Forestiera verrucosa (or glauca) Raf. Branches terete verrucose, leaves petiolate coriaceous glaucous entire obtuse elliptic or suboboval, base acute, fruits fasciculate peduncu- 
late oblong obtuse-found in Florida by $\mathrm{Dr}$. Baldwin and mistaken for F. ligustrina by Collins altho' nearer $\mathbf{F}$. porulosa. 'The warts are remarkable similar to those of some Chionanthus, unequal oblong flat rimose, the leaves are uncial quite glaucous on both sides, slightly reticulate and with no pores beneath, but a few scattered white small warts or dots, probably an Aecidium or parasitical fungus; the berries are similar to Barberries as long as the peduncles, and dark purple.

719. Forestiera porulosa Poiret. Adelia do Mx. Borya do W. P. Elliot. Leaves coriaceous sessile oval lanceol. obtuse, margin revolute entire, beneath porulose punctate and rusty-Sea shore of Florida, flowers and fruits not seen, even by Elliot.

720. Forestiera cuneifolia Raf. Branches rugose subangular, leaves petiolate cuneate lanceol. acute entire smooth, a single rufous nerve, fruits lateral subternate naked ovate acute subsessile-Discovered in fruit by Dr. Ward on the banks of the Wabash, seen alive without flowers. It may be a Nudilus or some. thing else, altho' quite near F. ligustrina, but leaves quite cuneate and often alternate, uncial, neither coriaceous nor membranaceous.

721. Forestiera cassinoides Poir. Adelia Br.t. 36. Borya W. P. \&c. Leaves petiolate oblong obtuse coriaceous smooth, margin revolute, beneath reticulate-Antilles and South Florida.

722. Forestiera (or Carpoxis) nitida Raf. Borya do Loud. Cycl. Leaves opposite and alternate ovate acute serrulate shining-This and the two next, I only find noticed in Loudun Cyclop. of plants, who does not quote his Authorities, but.given them as North American. 
They may be of a different Genus and Tiproximate to Carpoxis by the leaves not quite entire. 728. Forest. (or Carp.) Prinoides Raf. Borya Loud. Leaves ovate lanceolate serrate -Is it Ilex prinoides? flowers green, leaves $2 \frac{1}{2}$ inches long, one broad.

724. Forest. (or Carp.) retusa Raf. Borya Loud. Leaves alternate tapering in short petiols, retuse emarginate mucronulate very smooth glaucous.--Very near to my Ilex retusa but that is a real Ilex with 4 seeded berries.

725. Carpoxis spinosa Raf. Adelia acuminata Mx. ic. 48. Borya W. P. \&c. Bigelowia Sm. Branches spinose, leaves petiolate, rhomboidal, lanceolate, serrate (entire in the figure) acute smooth, fruits subternate drooping oblong rostrate acuminate-Carolina and Georgia, margin of streams, the description and figure of Michaux do not agree, and Elliot Sp. appears distinct. Leaves uncial, fruits long on filiform peduncles. Stamens over 4 ?

726. Carpoxis inermis Raf. Borya acuminata Pursh, Elliot \&c. Branches not spinose, leaves oval lanceol. attenuate at both ends petiolate membranaceous serrulate-Carolina, only seen dry by Elliot, who says that it has really 4 stamens.

727. Nudilus paradoxus Raf. fl. tex. \&c. Quite smooth, branches terete, leaves opposite and altern. lanceolate sessile acute entire fasciculate, fem. fl. peduncled racemose 2-4florefrom West Kentucky to Texas, very rare, a small shrub 3 to 5 feet high, flowers small vernal before the leaves, which are uncial rather thin and commonly alternate, berries ovate black? but not seen ripe.

728. FRAXINUS Lin. and all Authors. This Genus ought to follow the last, and I could 
give a Monograph of 32 Species at least, while our $\Lambda$ uthors have only 7 or 8 ; but Bosc and Loudun have noticed ¿7 North American sp. while Wildenow and Persoon had only 10. However I have but a dozen sp. in my Herbarium often withont flowers or firuits, and I must delay this labor; when I will easily prove that this extensive Gienus must be divided into 5 Genera at least, and I am now going to establish them.

72!). Fraxinus Raf. all the species with naked flowers, without calix as in Nudilus, 2 stamens, and finit a winged samare. Leaves pinnate, flowers paniculate polygamous.

730. LEI'T LLIX Rat.' 'Those difiering by a small calix 4dentate \&c. Such as $\mathbf{F r}$. caroliniana, acuminatu, pubescens, juglandifolia and many other American sp. but Bose has not noticed this important character.

731. ORNAN'IIIEs Raf. 1815. Ornus P. Pursh, B. li. Sc. Quite different by having not only a calix, but also a corolla of 1 petals as in Chionanthus.. Ornus being the root of many names I changed it to OrNantiLs meaning the flowering Ash : $3 \mathrm{Sp}$. at least O. rotundifolia, mannifera and Americana.

732. APLILIA Raf. Flowers and fiuits to be examined and described, leaves simple. Probably more than a subgenus. 'Two Sp. at least. A macrophyla and laciniata, the Fr. simplicifolia of late Author's.

733. SAMARPSLS Raf. $\Lambda$ minute tridentate calix, stamens 3 ? Fruit a peculiar samarc obovate with 3 wings like IIalesia, seed triangular. Leaves pinnate-This must constitute a very peculiar grenus, the flowers must be better described.

734. Samareses triptera Raf. Fraxinus do 
Nuttal, Elliot. Folioles about 7 obovate entire subsessille obliquate, villose and pale beneath, nerves smooth-In the Oak forests of Carolina.

\section{APPENDIX.}

I must conclude here this third part of my! New Flora and first of my New Sylva, not being able to include in it all our New Trees and Shrubs as I expected, owing to the need I had to enlarge my labors by illustrations and monographs of compared or revised Genera and Species of Trees and Shrubs. Another part shall be required for this New Sylva; since I have only revised one half of what $I$ intended. In the prolific. Genera Quercus, Salix, Populus, Betula, Hicoria, Kalmia, Mimosa, Magnolia, Illicium, Azalea, Ribes, Rubus, Calycanthus, Tilia, \&.c. I have few additions to make, and I have already illustrated elsewhere the G. Vitis, Rosa Abies, Aker \&c. But there is nevertheless a number of Genera as yet untouched that require revision or additions-such are-Andromeda, Vaccinium, Rhamnus, Ilex, Viburnum, Lobadium, Aesculus and Pavia, Prunus and akin Cerasus, Padus . . . The Coniferes, Pomiferes, Hypericines, Malvaceous . . . and also Myrica, Nyssa, Fraxinus, Artemisia, Lantana ... besides all our Palms, Yucas, Smilax, Zamia, Cactus and Upuntia.

Several of our small Genera are pretty well settled, such as Olea, Catalpa, Callicarpa, Ptelea, Pinkneya, Staphylea, Fothergilla, Dirca, Menziesia, Mylocarium, Bejaria, Illicium, Hopea, Halesia, Corylus, Carpinus, Platanus ... . But others have great additions or improvements to receive, for instance Clethra, Aralia, Asimina, Chiococca, Cyrilla, Itea, Sambucus, 
Berberis, Arbutus, Myrtus, Ficus, Avicenhia . . 'There is also a number of new or rare 'Trees and Shrubs discovered in Florida and described by Bartram 50 or 60 years ago, that are not yet received by our supine Botanists -others of Robin disc. in 1802, described 1807 and by me again in 1817 in Florula Ludoviciana, are yet quite neglected by them-Even those few noticed or well ascertained by Lewis and Clarke 30 years ago, in Oligon, are hardly known. All these ought to have been long ago added at least as Synonyms or in an Appendix to our Botanical Works, and 1 mean to do so, unless introduced by me in the proper monographs; I will now add here the names of the most remarkable among them.

Among Bartram's Trees or Shrubs of Florida were Nyssa coccinea, Lycium salsum, Corypha repens and obliqua, Areca floridana R. (Corypha palma B.) Erythrina corallodendron, Magnolia fragrans and acuta Raf. and several Sp. of Michaux long before him, Quercus incana and many others, many Sp. of Azalea, Aesculus, Myrica, Lantana, Prinos, Andromeda ... also Cupressus purpurea Raf. Rhizophora conjugata, Agave vivipara, Carica papaya or floridana Raf.... Besides several new Genera, my Xiphodendron, Nestronia, Sclerotris, Piloblephis \&c.

Among those of Lewis and Clarke are my Sorbus pumila, Sambucus ceruleus, Junipcrus radicans, Betula rupestris, Pinus humilis and macrocarpa, Pyrus fuscata ... besides several Sp. of Cactus, Ribes, Vaccinium ... and all my new Firs see Abies.

Among those of Robin and Louisiana to be admitted in our Sylva, are tiny Laurus ludovicieria, " isinus disculor, undulata and lacera, Arbutus obtusifolius, Cornus polygulıta, Ascyrum grandiflorum, Hypericum rostratum and fulgidum, Tilia stenopetala, Frangula fragilis, Prunus stenophyla, Gleditsia heterophyla, Ptelea tomentosa, Hicorius intercínolia, Cassine ramulosa, \&c ... Besidks 1.1Y N. Li. Chimunthus, Adnaria, Diplonix, Pseudopetalon, 1'hilostemon ... all described since 1817 !

We should look in vain for these Trces and Shrubs in the Works of our Compilers and neglectful Botanists. They will all be noticed again in my New Sylva, or given as sy. nonyms when rectified.

END OF THE THIRD PART. AND NEW SYLVA FIRST PART 
96

\section{INDEX OF GENERA.}

\section{SUBGENERA AND SYNONYIS OF TIIIS NEW SYLVA.}

Synonyms are in Italics-References to the numbers.

Abelicea 572.

Adelia 712.

Agastianis 704-5.

Amorpha 507.

Anthclis 549-51.

Aplenda 705.

Apleria 676.

Aplilia 732.

Audibertia 606 .

Bdsilima 674-6.

Bigelowia 7 12. Borya 712.

Broussonetia 577 to 584,704 .

Bumelia 5 $+5-8$.

Caprifolium 516 to 525 .

Carpoxis 714, 725.

Carpodetus 607.

Castanca 695-98.

Ceanothus 607 to 621 .

Celastrus 506.

Celtis 552 to 566 .

Cephalanthus 538 .

Cephalolhymus 604.

Ceratiola 596.

Chamedryon 653.

Chionanthus 706 to 711 .

Chrysobalanus 539 to 542 .

Chrysophylum 543.4.

Cistus 549.51.

Cladrastis 699, 700.

Colema 594.

Crategus 501.

Cunila 600.

Cypheola 525.

Diervilla 529-30.

Diodeilis 600.

Diospyros 537.

Distegia 525-6.

Empetridia page 48.

Empetrum 594 to 599 .

Endammia 595.

Epicostorus 671.

Euleucum 594.

Eunemium 525.

Evonymus 622 to 632 .

Fagus 688 to 694 .

Forestiera 712 to 725 .

Fraxinus 728 to 734 .

Fusticus $57 y$ to 583 .

Gardoquia 600.

Gonondra 705.

Hamamclis 509 to 515 .

Horanthes 549.51.

Hydrangra 677 to 687 .

Ilypoina 607.

Kantemon 523-5.

Leptalix 730.

Linociera 706.

Lonicera 516 to 530 .

Maclura 577.

Mayepca 706.

Megasteira 676

Melissa 600.

Morus 577 to 593 .

Nestronia 503-5.

Nudilus 715, 727.

Ornanthes (Ornus) 781

Pentinius 623, 632.

Physcondra 624.

Physocarpa 667-70.

Piloblephis 604-5.

Planora 572.

Platomesus 622.

Plcurostena 573-4.

Polygonum 573-6.

Pomaderis 607.

Pyrus 508.

Rafinesquia 600.3.

Rhamnus 505, 572.

Samarpses 733-4.

Sapindus 531.

Salureia 604.

Schizonotus 672-3.

Sophora 701-4.

Sorbaria 674.

Sorbus 508.

Spermalauxen 575-6.

Spiradia page 61 .

Spirea 633 to 676 .

Spondolobus 542 .

Symphoria 528.

Toxylon 577-8.

Trilopus 509-15.

Ulmus 567 to 572 .

Virgilia 699 to 705 .

Viscum 532-6.

Xeromalon 501-2.

Xylosteon 527.

Zanthyrsis 701-2. 


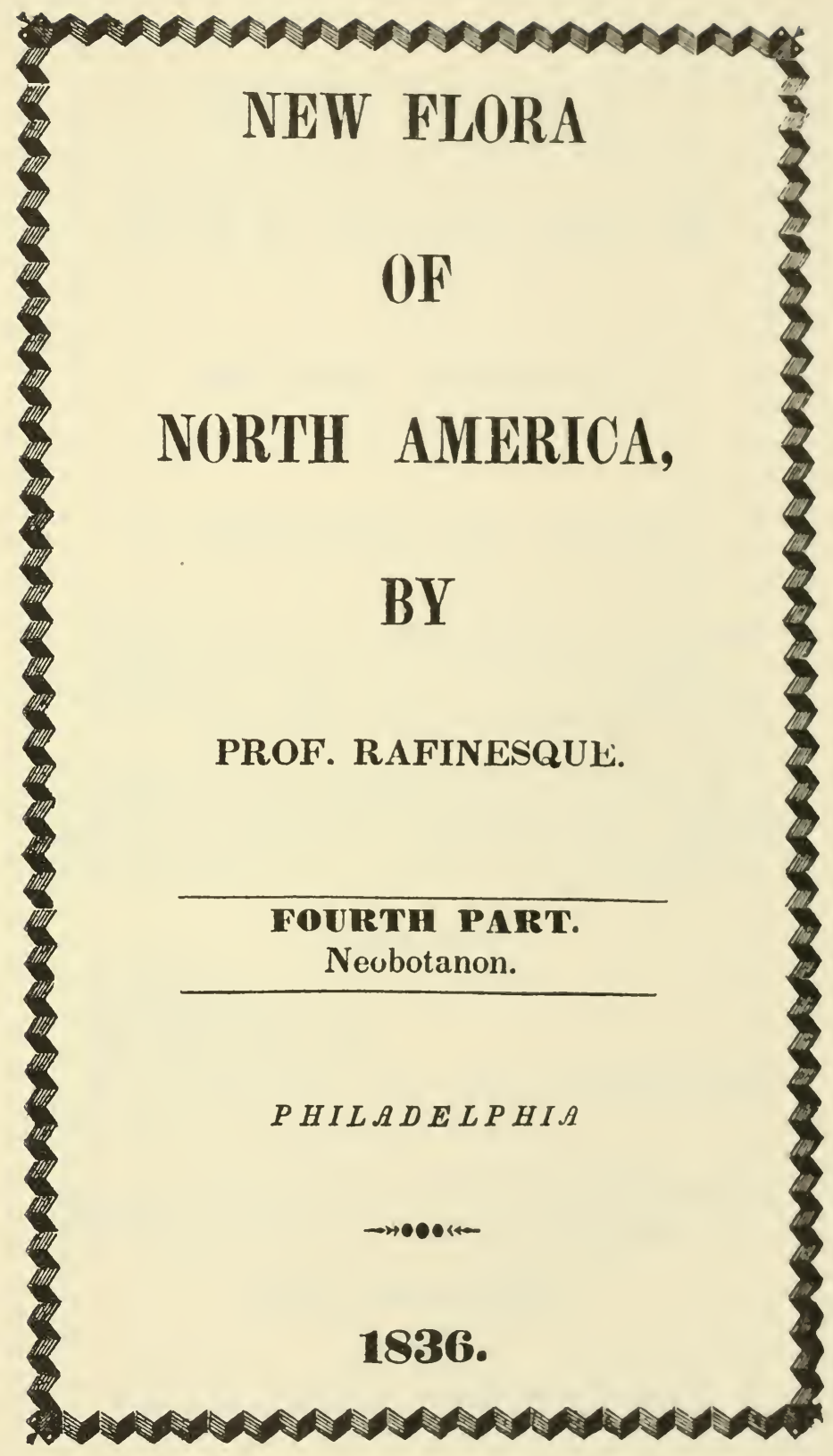




\section{NEW FLORA \\ A N D B O \\ or}

NORTIA M E RICA

OR

A SUPPLEMENTAL FLORA,

ADDITIONAL TO ALL THE BOTANICAL WORKS ON NORTH AMERICA AND THE UNITED STATES. Containing 1000 new or revised Species.

BY C. S. RAFINESQUE A. M. Ph. D. Prof. of Botany, the Historical and Natural Sciences, member of many learned Societies.

\section{IN FOUR PARTS.}

I Lexicon and Monographs.

II Neophyton \&c.

III New Sylva \&c.

IV Neobotanon \&c-with Introductions, Sketches, Notes, Indexes, \&c.

The floral wealth in this wide land concealed Will be at last by learned care revealed.

\section{PIILADELPHIA. 1836.}

Price Five Dollars- $\$ 20$ for 5 Copies. 



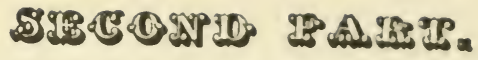

\section{NEOPHYTON}

\section{NEW TORA AND BOTANY}

OF

\section{NORTH AIMERICA.}

\section{BEING A SUPPLEMENTAL FLORA,}

To the various Floras and Botanical Works of Michaux, Muhlenberg, Pursh, Nuttal, Elliot, Torrey, Beck, Eaton, Bigelow, Barton, Robin, Hooker, Riddell, Darlington, Schweinitz Gibbs, \&c.

Besides the great works of Linneus, Wildenow, Vahl, Vitman, Persoon, Lamark, Decandole, Sprengel, Jussieu, Adanson, Necker, Lindley, \&c. Containing nearly 500 additional or revised New Genera, and 1500 additional or corrected New Species, illustrated by figures in Autikon Botanikon.

\section{BY C. S. RAFINESQUE, A. M.-PH. D.}

Prof. of Botany, the historical and natural sciencesMember of many learned Societies of Paris, Vienna. Bonn, Bruxelles, Bordeaux, Zurich, Naples, \&c. and in Philadelphia, New York, Cincinati, Lexington, \&c.

The Floral wealth in this wide land concealed, Will be at last by learned cure revealed.

\section{$P H I L A D E L P H I A:$}

PRINTED FOR THE AUTHOR AND PUBLISHER. 


\section{NOTICE.}

Botanists and Naturalists are informed that this work and nearly all my other works, manuscripts, figures, specimens ofc now forming a long Catalogue in my Bulletins, may be had from me either sold and exchanged for their own works, if they are not too costly.-My published works extend besides Botany, to all the other branches of Natural History, American History, Monuments and Languages, Ethnography and Geography, Astronomy with Celestial and Biblical Philosophy; Travels, Journals and Miscellanies \&c.-The Catalogues are given or sent gratis.

The other works to be produced by myself gradualy until 1840 and 1850 , will also be numerous-my History of the American Nations before and after Columbus was suspended after two volumes were issued; but shall now be resumed speedily, and the next volumes comprize the History of the Tsalagis or Cherokis.-Of the Tols, Chols, Chontals \&c, and other Atlantic Nations of Central America.-Of the Muyzcas and other Nations of New Grenada.-Of the Nations of Austral America \&c. These being some of the most obscure parts of American History, may become very interesting, and my researches will throw some new lights on those Nations, their origines, events and civilization. 


\section{N T R O D U C T I O N .}

\section{Fo the Fourth and last P'art.}

I have already explained that the delay in the completion of this work, was mainly owing to the contemporaneous publication of my Flora 'Teluuriana, where $I$ inserted the natural classification, main principles of natural Botany, and nearly 2000 new or revised fienera or Species (under 1225 articles) whereof many from North America likewise. I now conclude this work like the Fr. Telluriana in 4 parts, which will include over 1000 new Species with some new Genera, many revised Monographs \&c; but yet this is merely one half of what I have ready to publish on our Flora, in order to correct the glaring errors and omissions of our Botanists.

Whereas Prof. Torrey has been at last induced to undertake a general Flora of North America, a task which 1 had suggested to him many years ago, I shall delay my future additions and corrections until after his Flora is published. I call it his Flora, although he hopes that Nuttal and others will help him, because he means to insert in it only what he has seen and ascertained, according to his own notions of Species and Genera, overlooking varieties and deviations of specific or generic 'Types; an error into which he has fallen in common with several other Botanists, who have reluctantly adopted the natural methods of Botany.-But time will rectify these absurd and obsolete notions, and as we now restore, adopt and value the labors, genera and varieties noticed by the fathers of correct or natural Botany, Adanson. Jussieu, Necker, Richard, I a mark \&c, those of 
our modern IMProvers will be along with mine properly valued in due time-There is a tendency to resist improvements and neglect facts for awhile by the old schoils of science, which are afterwards taken hold of by more liberal and enlightened teachers or pupils.

Therefure my own Flora and that of Torrey will not interfere in the least, but be supplemental to each other; while his labor will probably save me the trouble of writing many Monographs, or verifying many synonyms and quotations. When his Flora will be concluded, I shall have me:ely to publish my additions to it, in order to complete our real Geveral Flora, of all the plants actualy known to me or others.

It is well known that notwithstanding the greatest industry and exertions, it is not possible for any botanist (or even a set of them) to collect or see all the plants of a vast region like our own: therefore there are many plants known only to myself or a few others; and if besides they are short sighted, or lack the botanical sagacity of ascertaining generic and specific characters, it may happen that they will overlook many such, even whin met with in the woods or in herbals.

As I think that I am gifted with a peculiar sharp sagacity in discriminating Genera and Species of Plants and Animals, it hehoves me to use it in order to rectify these objects and the sciences relating thereto.-It is what $I$ have often done, am now doing, and will continue to do as long as I live, not being prevented by the sneer or neglect or any ne. whom I consider less sagacious than myself, who cannot discriminate between the most conspicuous characters blended by the Linneists or modern Blenders and Shuffiers. 
One of my main future works will be a complete Sylva of North America on our 'Trees ard Shrubs reduced to natural orders. Another on our Ferns \&c. There will be much to do yet in all the botanical classes, before they be properly rectined and made permanent. There is an ample field of observations and researches in the vast regions extending from Florida to Texas, Origon and Boreal America, and con. taining more Gen. and Sp. than Europe; even excluding the Mexican and 'Iropical States till Panama, that afford a vegetation equaly fruitful. Some of my future Monographs of the Genera or groups Prunus, Plantago, Gentiana, Euphorbia, Vaccinium, Andromeda \&c will contain from 40 to 80 Species.

In this last part of my Supplemental Flora, I will chiefly describe some of the most select and rare plants or shrubs which I have in my Herbarium; they are all figured in my Autikon like the others.-And I can vouch that they are all as good and genuine Species as any of our modern botanists, and much better than one ha $f$ of the linnean Species of old, often blending half a dozen; as in the Genera Geranium, Lichen, Conferva, Agaricus, Aster, Euphorbia, Veronica, Justicia, and 100 similar families rather than Genera, that included $\mathbf{1 0}$ to $\mathbf{5 0}$ Good natural Genera, comingled as men are comingled with the Monkeys, and Bats with Birds !!! by many ignorant men or pseudophilosophers lacking the sagacity of perceiving distinctions of parts and forms. 


\section{NEOBOTANON •}

OR SELECTED NEW PLANTS \&.c.

DICOTYLES.

735. OTAMPLIS Raf. Dioical, perigone 6 phyle, 3sepals internal narrower, male fl. 6 stamens monadelphous at base. Female fl. ovary single ovate, stigma sessile large capitate sublobate. Fruit a single monosperm berry? Voluble, leaves alternate, $f$. axillary racemoseAkin in habit $\&$ c to Menispermum, but not even of same family, lacking the multiple berries; it must form with I'selium of Loureiro another small family of plants, the PSELIDES distinct by single ovary and the stamens not opposed to equal petals. Pselinem of Lour. Mart. Bosc, Smith, Decand. \&c differs by Perigone with 4 sepals, 6 free stamens in male flowers, stigma 1fid. The Ps. heterophylum is a twining shrub, with alternate entire leaves, growing in Anam of Asia. Otamplis derives from Eared Vine.

736. Otamplis vitifolia Raf. stem twining striate. leaves on long petiols palmate or lobed, 5 nerved, glaucous beneath, base reniform, lobes acuminate entire, ovate in lower leaves, sinusses obtuse; racemes shorter than petiols subcompound.-A large herbaceous Vine, leaves quite smooth, lower ample 6 to 8 inches broad, petiols 8 to 10 inches long, upper smaller with 3 short lobes, racemes hardly over one inch long, flowers small geminate or ternate, whitish, sepals ovatoblong obtuse deciduous, the inner ones smaller and whiter. On Red River in Arkanzas and 'Texas. My specimens are marked a N. G. akin to Menispermum in Collins Herbarium. 
737. DIDIPLIS Raf. 1833. Calix persistent campanulate 4 fid, segments unequal acute. $\mathrm{Co}$ rolla none. Stamens 2, filaments exerted, anthers rounded, stigmas 2 subsessile. Capsule globular bilocular polysperm. Leaves opposite, flowers axillary sessile.-A very distinct Genus blended with Peplis by Nuttal and Decandole, which has a calix 12fid and 6 stamens! the Peplis indica with spicate flowers, calix 8 dent. 4 stamens \&c, is also a peculiar Genus Nexilus Raf. meaning not with $6_{2}$ while Didiplis means two doubling.

738. Dimiplis linearis Raf. atl. J. and florula tex. 16-Peplis diandra Nuttal in Dec. prodr.-Stem terete ramose, leaves sessile proximate decussate patent linear obtuse uninerve, flowers sessile solitary axillary.-An aquatic plant of Red River, Texas and Arkanzas, habit of Callitriche, leaves narrow elongate uncial, flowers small green. In Collins Herb. it was marked a N. G. near Lythrum.

739. Diphyleia cymosa Mx. 'This tine plant seen by few, is so rare that its existence was doubted by some of our skeptics, notwithstanding the two fine figures of Michaux. It is a vernal plant of the Unaka and Cheroki Mts. where ferv botanists have divelt or travelled. My specimen in Col. Herb, was collected by Lyons, and is in fruit, the angular stem has only one leaf 6 inches broad, very angular but hardly dentate, the cyme is trifid and ramose, berries subovate obliqual. If it is a deviation it may be called var. trifida.

740. DISCOPLIS Raf. Dioical, male fl ... female fl. calix persistent oval hirsute Adentate, ovary sessile sub4gone warty, stigma sessile large sulcate. Fruit inclosed in calix, indehis- 
cent Akena or nut bilocular disperme, outside compressed discoidal rugose, 2 sides compressed sulcate, edges echinate, integument thick and hard, 2 oblong seeds inside. Herbaceous, leaves opposite, flowers in slender spikes-a most singular N. G. with very peculiar fruit, probably akin to the Euphorbines, or rather TragiDEs, but the male flowers are required to ascertain positively the natural affinities, perhaps even a typical Genus if they have 1 stamens inserted on a similar calix. The name means discus armed.

741. Discoplis serrata Raf. stem weak 2-3chotome flexuose smooth, leaves remote petiolate ovate serrate acute; spikes terminal filiform, bracts oblong longer than short peduncles.-From South Florida and Cuba, my specimens one foot high collected by Kin, stem fuscate, leaves acute at both ends yet subdeltoid and even sometime subcordate, some white hairs scattered above, spikes subracemose naked slender 3 to 4 inches long, with minute bracts, flowers small subsessile, the lower ones commonly abortive, remote and green, quite hairy.

742. Plantago multinervis Raf. Scapose, leaves petiolate subpilose broad lanceolate, attenuate at both ends, remotely dentate 9 nerved; scape longer sulcate hirsute, spike elongate, flowers scattered or interrupted, flowers smooth, calix carinate, bracts subequal ovate acute, style elongate persistent-found in Florida by Kin (Col. Herb.) near to Pl. interrupta which differs by entire leaves, with few nerves, shorter leaves and flowers, short bracts, calix not carinate \&c ... Here the leaves are 6 to 8 inches long, nearly 2 broad, spikes 6 to 10 inches long. Capsule disperme. 
743. Plantago albiflora Raf. scapose, leaves petiolate ample ovate, acute at both ends base repand dentate, \%nerved, very smoath; scape longer striate subpilose below, spike elongate imbricate, at base subverticillate, flowers smooth, calix and bracts scariose oblong acute, style elongate persistent pubescent.-In West Kentucky and Tennessce, leaves 6 to 8 inches long 3 to 4 broad, subglaucescent, spike very long pedal, calix whitish scariose with a green nerve. Akin to $\mathbf{P l}$. cordata but not at all cordate.

744. Plantago texensis Raf. Scapose, silky pilose, leaves elongate sessile linear obtuse hardly trinerve, scapes equal or longer terete, spike ovate and oblong dense imbricate, bracts and calix ovate obtuse villose, segments of corolla rounded concave, capsule disperme, seeds elliptic concave. - A very distinct sp. of Texas and Arkanzas, leaves semipedal, broader above, spikes from half inch to two inches long.

745. Plantago linearis Raf. Scapose, leaves sessile linear elongate entire quite smooth obtuse trinerve rugose; scape terete pubescent above, spike oblong dense, bracts linear triple of flowers, calix oblong obtuse.-In Florida found by Baldwin or Kin, nameless in Coll. Herb. Perennial as most sp. leaves 2.4 inches long, bracts remarkably long, spike short uncial.

746. Plantago globosa Raf. Scapose,leaves sessile lanceolate uncial, base wooly, entire uncial, scapes longer filiform sulcate, spike globose minute dense, bracts and calix scariose fulvous ovate acute.-Small, akin to $P$. indica and my Pl. atrof usca, leaves seldom over one inch, scapes 2 or 3 inches long, spike quite capitate very small as in $\mathbf{P l}$. indica. From South 
New Jersey to Florida in sandy soil, near Sea Shores.

74\%. Plantago amblodes Raf. Scapose, leares subsessile uncial oblong cuneate ?rinerve large obtuse teeth, margin and nerves ciliate; scapes hardly longer pubescent angular, spikes oblong densiflore pubescent, bracts equal ovate acute-Another small sp. from the banks of Arkanzas and Yazou Rivers. Some leaves are subpectinate by elongate teeth.

1 have described above 6 of my most distinct sp. of this Genus, 2 others Pl. gonophyia and atrofiesca of Illinois are in Atlantic Journal page 150 ; but $I$ have in my Herbarium a crowd of other N. Sp. and varieties, some of which are blended with $\mathrm{Pl}$. cordata, media, lanceolata, majo " foc of our botanists; when I shall prepare a Monograph of this G..they shall be distinguished. I have called them Pl. elliptica, compressa, crassifolia, undulata, repanda, rolnendifolia, riparia, longipes, pycnanthes, pañсті⿻上丨, pilosa, brevifulia, breviscapis, evioriza, serpentaria, peregrina, balduini.

78. Littorella rlexuosa Raf. 'This G. was not deemed American, and this sp. will form perhaps a N. G. when examined alive; it is at least a subgenus, which I call Xamotris (dwarf raceme) and it differs by calix unequal, imbricale segments of iuner perig. or corolla "lso unequal. Hiabit scapes racemose without bracts._- Scapose, leaves cespitose linear obtuse falcate smooth, base wooly, entire or with a few scattered gashes, uninerve; scapes shorter flexuose racemose pauciflore-Sent me from Alabama and found in Arkanzas by Nuttal. deemed by him a nameless Plantago in Coll. herb. annual, leaves 1 or 2 inches long narrow, 
scapes with 5 to 7 flowers on long pedicels, calix lanceolate acute, segments of corolla linear acute, 3 or 4 as in Littorella, some flowers geminate.

749. Rivina or Pisrecea acuminata Raf. Riv. levis of $\mathrm{Mg}$. and Nut. In Col. Herb. not of Antilles nearer to brasiliensis!-Herbaceous smooth, stem branched sulcate, leaves ovate oblong acuminate base rounded, margin subrepand; racemes axillary erect longer than leaves -From Florida to Arkanzas, 2 or 3 feet high, leaves 3 inches long thin and petiolate, racemes 4 to 6 inches long, flowers white, sepals of perigone 4 ovatoblong obtuse persistent and greenish after anthesis, stamens 4 or isopere as in the real Gr. Piercea of Miller, see my fl. tellur. 635, Rivina having 8 or 12 stamens. Habit like Phytolaca but berries globular one seeded, types of Nat. Family Rivinidia fl. tel. 634 .

750. Rivina or Piercea obliquatea Raf. Riv. hamilis of some Am. bot. not of AntillesHerbaceous nearly smooth stem simple sulcate, leaves ovatoblong subrepand, base commonly obliqual, end attenuate obtuse and mucronate, petiols somewhat pubescent, racemes erect equal to leaves. - everal sp. have been blended in R. humilis, this is guite distinct, found in Florida by Baldwin; a small plant hardly pedal, leaves smaller 1 or 2 inches long, pubescence extending sometimes to nerves and racemes, these short with fewer and smaller flowers, sepals of calix linear oblong obtuse whitish, style elongate, stig. capitate-as our botanists have mistaken these two plants (they are not in Elliot) it may be needful to state that the real $\mathbf{R}$. or P. Iumilis is frutescent quite pubescent, not sulcate, with acuminate leaves and larger 
red berries.-While $\mathbf{R}$. or $\mathbf{P}$. levis has stem terete, leaves not repand marginate of red, and flowers redish also with obovate sepals.

751. Plumbago Flomida Raf. (Collins herb) stem slender virgate angular, smooth, leaves minute ovate acute, spike slender base squamose denudate, flowers terminal few, bracts ovate reflexed, calix with stipitate glands.This G. was not known to be N. American, the specimen of Collins was collected by Ware in East Elorida, it is pedal, with small leaves and flowers less than one inch long.

752. Melothria nigra Raf. 1820, An, nat. 112. M. pendula E. and most of our Authors, stem. filiform angular trailing, leaves roughish subreniform 5lobed remotely denticulate, petiols filiform elongate, flowers polygamous and monoical, peduncles uniflore, in the male multif. berries globular smooth, pisiform black,-From Carolina to Kentucky, trailing $\mathbf{3}$ to $\mathbf{1 0}$ feet, leaves and flowers small, these yellow. It has several rar. see my Monographs; but all are distinct from the M. pendula of Antilles, Linneus said that sp. grew from Canada to Jamaica, but I never found it in the Northern States, others have and ascribe to it a red berry, is it another sp. or the next? In this the berries are shining black scarcely larger than a pea.

753. Mreotiria repanda Raf. Stem sulcate twining, leaves thick roughish cordate 5angular subtrilobe, repand sinuate, teeth obtuse mucronate, peduncles uniflore, berries oblong oliveform smooth.- This is most likely the sp. of Linneus and many botanists, although L. ascribes an oliveform tuberculate berry to his, petiols shorter than leaves and peduncles, I cannot say if the berries are black or red, my spe- 
cimen is from Arkanzas.

754. Melothria punctata Raf. stem filiform angular, leaves cordate 5angular smooth entire or subdentate, thin glaucous with minute black dots on both sides, petiols equal to leaves filiform ; peduncles uniflore, berries red elliptic oliveform smooth-sent me from New Orleans by Dr, Riddell as the M. pendula, the dots appear black glands as in Hypericum, berries apparently red in the specimen, shape and size of a barberry.

755. Melothria pendula (or edulis) L. Brown, Lunan. Sw, and Antillian Authors.Scandent. petiols auriculate or alate, leaves rough trilobe or triangular subcordate sinuate, obtuse, fl. polyg. dioical, peduncles uniflore, berries pendulous ovate black size of a nutmeg. In Jamaica and the Antilles, totally unlike the two others, fruit very large eaten when ripe and pickled unripe says Lunan, probably also in Florida and cultivated in Louisiana.

756. RIDDELIA Raf: family Cleomidescalix 5 sepals subequal, petals 5 unequal, stamens filiform short, commonly 5 subequal inserted on a flat disk, ovary sessile oblong, stigma sessile obtuse. Pod sessile, linear compressed bivalve polysperme bilocular, partition contrary to valves, edges thick flattened. Frutescent, leaves simple stipulate, alternate flowers, extra-axillary solitary.-Another pretty G. of the family CLeonidia, which now contains 25 at least, (see my reform of it ; ) this is remarkable by habit and fruit near to the G. Peritoma, Warea, N. Podolobus R. or Stanleya N. \&c but distinct from all these, yet they all belong to my family of Cleomines, not a section of Capparines. Dedicated to Dr. John 
Riddell who sent it to me from New Orleans as an unknown $G$. with several other rare plants, he is the author of a Western Flora and discoverer of many new plants there. If his name has been employed already, we may substitute Antiphla serinata Raf.

757. Riddelia antiphyla Raf. Leaves smooth lanceolate acute, equaly serrate, petiols short pubescent, stipules subulate; peduncles extraxilary unifl. equal to petiols, sepals colored linear lanceolate acuminate pubescent, petals subequal cuneate obtuse, pod divergent strait equal to leaves-apparently a virgate shrub, branches fuscate terete rimose, leaves and pods uncial, almost opposite to each other, flowers yellow small, stamens $\mathbf{5}$ or $\mathbf{6}$, shorter than flowers. Pods fuscate smooth, seeds black compressed squared truncate.

758. Sesuvium veriucosum Raf. prostrate roughened by warts, leaves thick petiolate obovate and cuneate obtuse entire, flowers axillary subsessile commonly solitary-a very distinct sp. with the habit of Portulaca oleracea, but enentirely covered with rough tubercules and warts, when dry of a fulvous glaucous color all over, many branches, leaves small, flowèrs 1 to 3 in the axils, campanulate, white inside, stamens many, and thus totaly unlike the S. pentandrum of Elliot which is my G. Squibbia maritima. This sp. was sent me from Arkanzas and the Chacta Conntry, where it grows near streams on the Yazou and Salt River.

759. Spergula ralcata Raf. Diffuse decumbent smooth glaucous, leaves linear falcate acute, base connate, peduncles axillary equal to internodes and leaves, erect, segments of calix ovate obtuse equal to petals and capsule.-On 
the banks of the lower Ohio, and Missouri rivers, a small plant extending 3 to 6 inches with many short branches, leaves 3 lines long.

760. Dionea sessiliflora Raf. atl. J. 78. Petiols winged oblong or cuneate narrow, acute at both ends, leaves bilobe ; flowers sessile agregate 3 to 5 , bracts lanceolate.-The beautiful G. Dionea is no longer monotype but has deviated sp. D. muscipula the type is quite distinct from this by petiols broadly obcordate, flowers corymbose. Seen alive in our gardens as well as a variety Uniflora, smaller uniflore, with broader shorter leaves, petiols oblong acute winged. Both native of Carolina, flowers white estival, leaves irritable in all. This G. is the type of a Nat. Family Dionidia different from Alsinidia by single style.

\section{BORAGINES}

761. Pulmonaria flliptica R. leaves elliptic acute at both ends, the radical on very long petiols, upper ovate; flowers axillary pedunculate nodding, calix with short segments lanceolate acute.-In the Apalachian Mts. of Virginia and Carolina, stem smooth branched bipedal, flowers blue and small.

762. Lithospermum gracile Raf. annual, silky villose, stem slender erect virgate naked below, leaves petiolate linear acute adpressed, flowers terminal subsessile, tube of corolla longer than calix, segments of corolla oblong obtuse.-A very striking sp. sent me from Alabama and found on Red River Arkanzas and 'Texas by Nuttal in Collins herb. where noted as perhaps a N. G. but I see no difference, unless the fruit be different, the corolla is realy funnel .shape, but the lobes deeper or longer. Stem semipedal nearly simple, leaves uncial 
sometimes revolute on the margin, flowers terminal axillary white and small.

763. Lithospermum strigosum Raf quite warty strigose, leaves sessile ovatoblong, fl. axilary sessile, calix lanceolate rugose verrucose strigose, seeds fuscate obovate.-In Florida, found by Kin, my specimen is only in seed, pedal covered all over with white warts ending in a white rigid hair forming a great roughness, leaves uncial rigid, calix large unequal.

764. Lithospernum cuspidatum Raf. stem erect ramose sulcate hirsute, hairs spreading, leaves linear lanceolate cuspidate rugose ciliolate hirsute rough ; flowers axillary solitary, subsessile, seeds smooth lucid ovate fulvous not punctate.-In Alabama and Georgia, pedal, leaves uncial narrow, branches short erect angular. Very different from $\boldsymbol{L}$. angustifolium $\mathbf{M x}$.

765. Lithospermum ciliatum Raf. annual erect subdichotome above, hardly hispid, leaves sessile linear obtuse ciliate, flowers axillary subsessile. segments of calix linear ciliate as long as corolla.-Found by Hart on Red River and by Drumond in Texas, semipedal slender few leaves, flowers subracemose.

766. Lithospermum floridanum Raf. annual erect ramose canescent, hairs adpressed, stem terete, leaves linear lanceolate acute, flowers subracemose, calix equal to tube of corolla, seeds pilose.-In Florida much branched, leaves rather lax patent, linear on the branches, flowers chiefly pedunculate, but some sessile, with or without bracts, segments of calix more unequal than usual, lobes of corolla obovate, seeds yellow pilose globular.

I have thus added $5 \mathrm{sp}$. to this $\mathbf{G}$. which had already 7 in Eaton, but some of these do not be- 
rong to the Genus, the $\boldsymbol{L}$. latifolium forms my G. Cyphorima 1819 having 5 pits outside of the mouth of corolla, with 5 corresponding knobs inside.

767. Batschia albiflora Raf. annual, glaucous, hairs all over white adpressed, stem simple, leaves petiolate ovate acute, flowers few terminal, tube of corolla equal to calix. limb campanulate large plicate hardly lobed.-On the River Arkanzas on sand bars found by Nuttal, deemed a N. G. but quite like Batschia although habit a little different and corolla less lobed, if a subgenus it may be called ONoknLes a Grecian name of Anchusa. Pedal, first leaves opposite, small hardly uncial, flowers few large.

768. Lycorsis? axillaris Raf. stem flexuose angular, leaves sessile linear lanceolate slightly scabrous and pubescent, flowers axillary sessile, calix villose tomentose canescentFound in Florida by Mr. Ware, marked a Lycopsis in Coll, herb. but habit rather of Lithospermum, small plant, leaves elongate, over one inch long. Very different from $\boldsymbol{L}$. virginica. OMBELLIFEROUS PLANTS.

769. MESODISCUS Raf. dioical involucre 1 or none, involucels 2 , male fl. with a thick lenticular disk convex central, no calix ! no style! petals 5 obcordate, stamens 5 equal to petals, anthers globose bilobe, female $\mathrm{fl}$. and seeds unknown .... Leaves commonly ternate, Rowers white.-Very singular Genus, perfectly dioical, which appears a paradox in this family of plants: several G. however are polygamous. Although the fruit is lacking yet this Genus appears perfectly distinct and unlike any other except the next. I have $2 \mathrm{sp}$. of it, one of which is anomalous again by a triple componnd umbel. 
770. Mesodiscus simplex Raf. stem terete solid base subangular few leaved, leaves remote, petiols angular, folioles 3 entire oblong or lanceol. acute, middle one acuminate; umbel single involucre none, involucels 2 setacenus, 7 umbellules 9-12flore, pedicels unequal, petals obcordate concave.-Sent me from Alabama, stem slender pedal or more, folioles uncial, last leaf a single linear foliole remote from umbel, flowers quite white.-Var. major has stem bipedal, the lower leaf with 5 folioles.

771. Mesodiscus proliferus Raf. stem terete solid, leaves remote, petiols carinate, folioles 3 or 5 lanceolate entire very acute, sometimes falcate : umbel thrice compound, first involucre with 5 linear folioles, second involucres none or one linear, commonly $\mathbf{5}$ umbellules, 7-15flore, involucels 2linear, petals flat obovate scarcely obcordate.-Also from Alabama,leaves sometimes with only 2 folioles, the lower have 5 subpinnate. Quite smooth and with white flowers like the last: the triple umbel is a great anomaly.

772. IATARIA R. ombelif. polygamous. Involucre none or 1 or 2 minute, involuces 3-6 subulate. Calix minute 5toothed petals equal round obcordate incurved, 5 short stamens, disk almost conical, 2 short styles divaricate. Seeds elliptic flat and thin, 5 striated, convexely incurved, surrounded by a thick fungose white margin over both seeds. Leaves ternate, flowers ochroleucous-united to Peucedanon by Nuttal (who did not see the perfect flowers) which differs by petals oblong, seeds oval wingell around, flowers yellow ofc. Sataria was an ancient name of Peucedanon. A few male flowers are mixt in umbels. 
773. Sataria linearis R. Peucedanon ternatum Nut. \&c. Stem virgate terete solid striate, leaves few remote on long petiols, folioles 3 sessile linear, very long and narrow, acute at both ends; umbels axillary and terminal, invol. linear or none, umbelules 5-7 and paucifloreIn Alabama and Georgia, perennial smooth, commonly 3 leaves and 3 umbels, folioles 2 or 3 inches long-Var. longipes 5 or 6 leaves, lower with petiols exceedingly long 10 to 18 inches, umbels 1-2terminal. Flowers pale yellowish in both.

774. KERASKOMION R.ombelif. both invol. 2-3phyle, calix hardly 5toothed, petals obovate plicate, stam. filif. styles short divaricate. Fruit smooth globose as in Aethusa. Leaves decomposed, umbels small, flowers white, axils bulbose-united to Cicuta by the Authors. nearer to Aethusa by invol. and seeds, quite peculiar by the bulbose habit. The name was one of the Greek terms for Aethusa or Oenanthe.

775. Kerask. bulbifenum R. Cicuta bulbif. of most of our botanists-stem ramose terete fistulose, lower leaves triternate, others biternate or ternate, folioles linear serrate pectinate, upper simple entire, bulbs gemmular squamulose; umbels terminal na'ied-a very singular plant growing on banks of streams from Canada to Virginia, described on the living plants, and found very different from Cicuta. Flowers estival, minute and white, sometimes hardly any but bulbs profuse, they appear to reproduce the plant, are real buds with oval acute scales (as in buds of trees.) Stem bipedal, leaves sometimes subverticillate. It is doubtful whether the linnean plant is not different, Linneus says 
stem angular and leaves capillary, Michaux says like Fennel. My plant is not such, but they may have seen bad specimens.

Genus DAUCUS and akin.

Here is a striking instance of the blending propensity of our Botanists, who do not take care to look sharp, overlooking the most evident characters. I can speak with confidence, since I did the same for 20 years concerning our wild Carrots, until at last having noticed some kinds with bipinnatifid involucres and others with entire involucres, I was led to notice observe and revise the genus and akin. It had even been supposed that our Carrots were naturalized, while they are found native in the wildest localities. My researches have already led me to ascertain 3 genera and a dozen species, all probably deemed $\boldsymbol{D}$. carotta or pusillus when seen by others. The nature of the involucres and seeds is essentialy generic here, else Daucus and Caucalis should be only one Genus. 'The G. Dasyspermum 295 of Necker which he says had a fruit hispid muricate all over, includes also several, since it was formed out of 'Fordylium,Conium, Ammi and Scandix ! having muricate seerls.

776. DAUCUS Raf. involucres pinnate or multifid, partial with entire or trifid folioles. calix 5toothed, petals obovate emarg. inflexed, outer often larger radical unequal. Sieeds with 4 aculeate wings. Leaves decomposed, flowers white or red.-This is the type to which belong the real Carrots: I must now add here for contrast all the Genera blended thereto. For the sp.see 783 to $\mathbf{7 9 2}$.

777. TIRICTA Raf. involucres simple polyphyle, partial similar, flowers polygamous 
radiate. Calix entire, styles divaricate, stigmas capitate, petals 5 unequal plicate involute. Seeds unequal oblong, with 1 or 3 ribs unequaly echinate cristate. Habit of Daucus. The name was an ancient one for Daucus.

778. Tiricta Daucoines Raf. stem virgate terete smooth; leaves few, lower on long petiols, upper sessile, bipinnate, folioles linear confluent cuspidate, margin rough; 2 or 3 umbels on long peduncles, invol. 5-8phyle, linear entire, umbels multiflore longer.-In the Pine barrens of South New Jersey, root annual? white perpendicular not odorous as in Daucus, stem bipedal simple, leaves slender, flowers small white autumnal. Compare the Leptocaulis echinatus of Nuttal.

779. BABIRON Raf. involucre none, partial oligophyle simple. Flowers similar, none male nor radiate. Calix hardly 5toothed, petals ovate obtuse flat equal. Fruit ovate rounded smooth, seeds with several rows of small scaly tubercles. Habit of Ammi and Leptocaulis.-How distinct from the last, the name was also an ancient one of Daucus in Egypt, 3 sp. at least, some of which are among the Leptocaulis of Nuttal in Decandole, but not of same Genus.

780. Babiron pusillum Raf. annual quite smooth, stem simple filiform striate, leaves short 2-3pinnate, segments linear acute, the upper setaceous; umbels trifid terminal filiform, involucre none or 1 subulate, partial 3-4subulate, umbelules 3-5flore, pedicels unequal-sent me from Alabama, and by Dr. Torrey from Georgia as the Daucus pusillus! see 788. Stem 4 to 6 inches high redish, leaves small finely cut, 
flowers minute few white. Nearer to Leptocautis than to Daucus.

781. Babiron mivaricatum Raf. Daucus do Walter, Leptocaulis do N. Dec. Ammi do Pers. and again Ligusticum pusillum Persoon! (Elliot) Sison pusillum Mx. Pursh, Elliot \&c. -Annual slender smooth dichotome divaricate, leaves triternate multipartite segments linear or setaceous, umbel. 5-6fid, umbellules commonly triflore, pedicels equal, invol. 3 lanceolate minute-in Carolina and Florida, bipedal not humble, my specimens are in fruit, brown, realy warty, hardly squamose. Here is a sp. put in 5 Genera!

782. Babiron dichotomum R. Ammi divaricat. Coll. herb.-Smooth dichotome, leaves short bipinnate. segments narrow linear, umbels 2-4fid, umbelules 3-5flore, pedicels unequal, involucels 1 to 3 minute-annual like the others, with slender stems semipedal, branches divergent but not divaricate, more like $\boldsymbol{B}$. pusillum than the last, but stem terete not striate nor simple, the tubercles of the seeds more scaly. Florida.

783. Daucus scadiophylus Raf. stem growed retrose pilose, leaves few short tripinnate hirsute, segments linear acute; involucres 5-6 foliose bipinnate! partial simple as long as flowers, petals equal not radiate seeds hispid.Florida, Alabama and Georgia, a Southern Daucus so unlike the others, as to be almost a N. G. I shall form a subgenus of it (with the next) Gringidium with involucres bipinnate petals not radiate. This is pedal and bipedal, the involucres nearly similar to the leaves, flowers small, seeds oblong hispid between the muricate ribs. D. Lucidus, being the same as D. gin- 
gidium, belongs to the same subgenus.

784. Daucus scariosus Raf. stem grooved foliose retrose pilose, leaves 2-3pinnate, segments lanceolate acuminate or cuspidate; involucres 6-8 foliose bipinnate, partial unequal lanceolate white scariose, longer than flowers, some trifid.-Annual or biennal root not odorous, leaves long and narrow, nerved.-Var. simplex simple stem pedal, a single umbel, hardly hispid-Var. ramosus branched hirsute, involucres hardly bipinnate, very long segments sometimes trifid. Found by myself in the glades of Pennsylv. autumnal, petals apparently not radiate, thus a Gingidium also.

785. Daucus brevicaulis R. Scabrous, stem nearly naked, lower leaves nearly as long tripinnate, segments confluent oblong bifid mucronate; involucres mostly trifid base scariose on the margin, linear elongate, partial linear and trifid shorter than flowers, petals radiate.-A singular sp. found in hills of Pennsylvania and near Philadelphia, with ample leaves 6 to 8 inches long nearly as long as the stem, with broad segments, roots biennial hardly odorous branched.

786. Daucus nudicaulis Raf. smooth, subscapose, scape naked grooved, leaves radical bipinnate segments linear laciniate cuspidate; umbel lax, involucres 3-5fid setaceous, partial linear equal to flowers, margin scariose, petals radiate-found with the last, perhaps a deviation, but it has another deviation var. pumila only 3 inches high, leaves larger than umbel quite linear-while the nudicaulis is 6 to 8 inches high, with short leaves 3 inches long, root white tapering slender.

787. Daucus levis R. Quite smooth, stem 
striate slender, leaves bipinnate small, segments linear acuminate; umbels small, involucres trifid shorter, partial simple, petals seldom radiate seeds echinate.-Not uncommon in fields and woods from New Jersey to Kentucky, pedal, leaves quite flat hardly nerved, stem not grooved terete.

788. Daucus pusillus Mx. E. \&c. annual, stem simple scabrous slender angular, leaves remote short bipinnate, segments linear acute, umbel single pauciflore, involucres trifid, partial simple, umbelules 1-3flore, seeds with wings deeply crested.-A sp. deemed doubtful by many or a var. of D. carotta like the others, but quite distinct; my specimen collected by Baldwin in Florida has only a few retrorse hairs, 3 small leaves, a small umbel; the seeds are large, with white wings deeply cut into pectinate stiff bristly crests. Perhaps a subg. Lophioplis near Tiricta.

789. Daucus brevifolius Raf, nearly smooth stem terete foliose not grooved, virgate, leaves short remote pinnate, folioles pinnatifid segments oblong acuminate ; involucres trifid, partial simple, seeds oblong pubescent hardly echinate.-Alleghany Mts. \&c, pedal, root branched not odorous leaves 1 or 2 inches long only, umbels small, peduncles sometimes grooved and with a few hairs, seeds fuscate small, petals radiate-Var. filiformis, stem filiform striate, involucres setaceous.

790. Dadcus heterophyus Raf. scabrous or subhispid, stem grooved branched foliose, leaves petiolate decomposed variable, the lower 3-4pinnate,folioles confluent lanceol. acuminate, upper bipinnate, folioles remote linear cuspidate; involucres tripartite elongate setaceous, base 
marginate of white, partial subulate marginate, seeds echinate.-This is the most common sp. from Canada to Louisiana in fields and woods, nearest to $\boldsymbol{D}$. carotta, but yet different. Root biennial odorous fulvous slender, stem 1 to 3 feet high, leaves 3 to 6 inches long, large umbel lax at first, contracted at last. Some varieties or deviations.

1. Var. Fumaroides. Lower leaves like Fumaria 4pinnate segments confluent, some involucres simple.

2. Var. Asper, stem very scabrous, leaves shorter 2-3pinnate.

3. Var. Laxifolius, nearly smooth, leaves with remote folioles.

It will be sufficient to compare carefully these American sp. with the European to perceive their distinctions. There are at least $6 \mathrm{sp}$. in Europe blended in $D$. carotta! or the garden kind native of the South, so easily known by large succulent root, stem hirsute deeply grooved, petiols carinate, broad decompound leaves, pinnate involucres \&c-they are $D$. maritimus. polygamous, exiguus, see Pers. Wild. Lam. \&o besides the 2 next, now before me.

791. Daucus strigosus $R$. strigose covered with white bristly hairs, stem grooved, leaves subsessile, pinnate and bipinnate, folioles oblong laciniate or pinnatifid acute, involucres pinnate broad with a thick margin, partial simple lanceolate. - A very distinct sp. sent me from England as a wild earrot, the hairs are thickly sct stiff and flat, petals radiate.

792. Daucus agrestis R. stem grooved scabrous, leaves remote subsessile base winged pinnate or bipinnate, folioles pinnatifid, segments oblong cuspidate; involucres pinnate or 
trifid base with a white marenal wing, partial lanceol. scariose. This is the wild Carrot of France and Germany different from the garden kind, root hard woody, stem 1 or 2 feet high, leaves 2 or 3 inches long, petals radiate. Also naturalized with us but scarce.

Thus the G. Daucus must be reformed in $\mathbf{G}$. and $\mathbf{S p}$. the foreign kinds form several other $\mathbf{G}$. or Subg. such as

793. VisNaga Raf. invol. perianthiform multipartite, segments trifid, partial polyphyle, umbels phorantiform at base, petals inflexed bilobe, seeds oblong çompressed striate smooth-united to Ammi as a subg. by modern botanists, but a peculiar G. seen alive. Types $\boldsymbol{V}$. vera and meoides.

794. Ballimon R. invol. o, 1 or 2 simple,partial 2-5simple, seeds with a thick integument and 3 rows of uncinate spines-Types B. $m u$ ricatum and maritimum, both Daucus do, auct.

795. Peltactila Raf. petals very unequal, seeds with spines bearing peltate Stars! flowers commonly yellow.-Types P. grandiflora, parviftora, aurea, hispida \&c all Daucus of Desf. \&c.

796. Staflinus $R$. seeds semiterete turgid ciliate crinite-St. setifolius and crinitus. Daucus do auct.

797. ENTASIKON Raf. Polygamous. Involucres 2-3phyl. setaceous, partial similar. cal. with 5 unequal persistent teeth, petals 5 equal. obcordate inflexed, stamens 5 equal, styles 2 thick ovate persistent, stigma obtuse. Fruit oblong smooth angular, lateraly divided by a lateral furrow. Leaves decomposed, flowers white.-A very striking $\mathbf{G}$. differing from all others known to me by the unequal calix and 
ovate styles. If it is a Trepocarpus of Nuttal, how did he neglect these singular characters! The name was a Grecian name of a Cherophylum.

798. Entasikom tenujfolium Raf. Athamanta cherophyloides Nuttal in Coll. herb. Trepocarpus aethusa? Nut. in Dec.-Quite smooth, stem angular, leaves pinnate and blplnnate, folioles linear setaceous acute thin; umbels trifid opposed to leaves, ombellules 3-7 flore, male $\mathrm{fl}$. peduncled, tertile nearly sessile. - Found in Arkanzas by Nuttal, foliage glaucous minutely cut, stem yellowish, umbels peduncled lateral, flowers white, seeds 4 or 5 times as long as broad.

799. Entasikon? tuberosum R. Phellandrium do Nut. in Collins herb. Root tuberose, leaves bipinnate, folioles linear obtuse-another plant found in Arkanzas, by Nuttal and widely separated from the last, although hardly different, except by broader obtuse folioles. The specimens are imperfect, but the roots are oblong rugose twin; in a note it is stated the stem rises 3 or 4 feet high, the upper leaves are nearly simple, and the germination is acotyle!

800. UPOPION. Raf. Polygamous or even monoical. Involucres none. Calix 5 dentate petals ovate obtuse flat (dark purple) styles divaricate. Seeds smooth elliptic each with 3 or 4 unequal large wings, commissure costate. Leaves simple ternate and pinnate, flowers dark purple,-This G. has been shuffled into Thapsia, Cnidium, Thaspium, Smyrnium \&c which like Zizia it must form a peculiar one, well distinguished from Thaspium having yellow flowers, by its red flowers, petals not acuminate, large unequal wings \&c. The name 
was an accient one of Thapsia, and I have ascertained $\mathbf{5}$ species, probably all deviations.

801. UPOPION PIN NATUM R. stem subangular, leaves pinnate, 5 folioles ovatoblong sessile acute serrate, base truncate obliqual, terminal base acuminate; fertile flowers subsessile,seeds with very unequal wings.-Discovered 1823 in West Kentucky glades and since in several other places, Alleghanies \&c, pedal, or bipedal, perennial like all the sp. folioles 1 or 2 inches long, terminal often larger. Flowers estival as in all.

802. Upopion LOBATUM $R$. stem striate, leaves all trifoliate, lateral folioles subsessile obliqual ovate acute serrate more or less lobed outside, terminal foliole petiolate, cordate ovate often trilobed; umbels multiflore, fertile and sterile flowers on short peduncles seeds elongate with narrow wings.- In Pennsylvania the Alleghanies, Virginia \&c, 1-2 feet high, leaves sometimes very large, and curiously or variously lobed or cut, flowers copious sometimes all fertile, but seeds unequal in size. $-\mathbf{A}$ var. $\boldsymbol{R} i$ gida or perhaps peculiar sp. has stem and umbels stiff angular canaliculate, folioles large all unequal obliqual ovate oblong unequaly serrate, lateral sessile, medial base truncate auriculate on one side.

803. Upopion trifoliatum $R$. stem angular striate, leaves all trifoliate, radical on very long petiols, folioles ovatoblong serrate, lateral obliqual, terminal on a long petiol, base rounded or truncate; none lobed; umbels pauciflore, flowers shortly pefluncled.-The most common sp. from New Jersey to Kentucky, bipedal, petiols often pedal, folioles uncial, the middle one sometimes deltoid. 
804. Upopion heterophylum R. Thaspium atropurp. auct. Stem striate, radical leaves simple cordate, stem leaves trifoliate, terminal foliole cordate or ovate, lateral ovate obliqual, all serrate; flowers peduncled, male on longer peduncles.-This is the original sp. known and called Smyrnium atropurpureum by Lamark, leaves uncial, stem bipedal. So much like Zizia cordata in habits as to have often been mistaken for a variety of it.

805. Upopion CORDATUM Raf. stem simple angular, all the leaves simple cordate petiolate, acute unequaly serrate; umbel single naked, flowers glomerate subsessile mostly fertile.-In the Alleghany Mts. evidently a very distinct sp. pedal, 3 radical leaves uncial, one lobate on the sides, two stem leaves remote larger.-These 5 sp. offer a beautiful illustration of the formation of species by gradual deviations of forms, from pinnate to single leaves. 'They have nothing left in common but smoothness and serrate leaves besides the flowers.

806. Zizia Parvifolia $R$. stem virgate grooved pubescent like the petiols, radical leaves small cordate trilobe crenate, stem leaves sessile trifoliate, folioles unequal ovatoblong acute unequaly serrate, medial larger; umbelules pauciflore with unequal slender peduncles. -Very distinct from $\boldsymbol{Z}$. cordata by pubescence small leaves mostly half inch long only, stem pedal, flowers polygamous yellow, seeds oval with 3 prominent ribs. Found in the Alleghany Mts.

807. Siumis (Sium) heterophyla Raf. stem simple fistulose costate, lower leaves on very long petiols trifoliate, folioles ovate serrulate, medial petiolate, middle leaves pinnate, 5 to $\boldsymbol{z}$ 
folioles lanceolate, upper leaf sessile trifoliate, lanceolate serrulate, involucres lanceolate reflexed.-Found from New Jersey to Illinois, in waters, rare, pedal and bipedal, folioles about 3 inches long, all serrulate sessile except the odd one; umbel with about a dozen of umbellules, 6 to 8 small folioles for involucres, the partial still fewer and smaller less reflexed, flowers while as in the Genus, quite distinet from $\mathbf{S}$. latifolia and akin species.

808. PHAIOSPERMA Raf. herb. 1833 page 77. Polygamous, Invol, one, partial few. Calix 5dentate, petals obcordate involute, styles elongate, stigmas capitate. Fruit smooth fungose ovate convex with a thick integument, no ribs nor angles nor wings nor thicker edge. Leaves sometimes opposite, polytome, flowers white small, seeds brown.-This G. which was. pronounced new by Torrey and a Polytenia by Nuttal, differs from it, as will be seen below, and chiefly by the involucre and the seeds convex and not concave outside. The name alludes to the brown seeds. I have corrected the characters by withdrawing from it $\boldsymbol{P h}$. verticillata, but uniting a new species.

809. Phaiosperma trifida Raf. herb. stem dichotome subcostate, leaves alterne and subopposite cuneate triparted, segments oblong subequal tridentate; involucre unique, partial 2-4linear-discovered in 1823 in the Western glades of Kentucky, pedal, vernal, leaves short, flowers small, seeds of a bay brown.

810. Phalosperma pulverulenta Raf. glau. cous pulverulent, stem dichotome striate, leaves alternate triparted segments oblong pinnatifid; involucre often lacking, partial 5-8 linear colored-In Florida, found by Kin or Baldwin, 
anonymous in Coll. herb. covered by a scurf, well branched, leaves short, flowers not so small nor so white, apparently ochroleucous in the specimen, umbels glomerate with many male flowers and very few fertile. The seeds not being ripe, I cannot be positive on the Genus, but the habit is quite near the last, the unripe seeds are ovate oblong smooth flat.

811. PACHILOMA Raf. (thick edge) Polytenia Dec. add to characters. Polygamous, invol. none, partial few. Fruit elliptic or obovate with a thick margin, middle concave striate. Type P. nutali Raf. Pol. do Dec. Tordylium Americanum Nut. in Col. herb. stem dichotome grooved roughened, leaves alt. and opposite triparted, segments pinnatifid cuneate, last trifid; involucels 3-5 linear, seeds elliptic. - Such are my specimens from Nuttal himself, and Arkanzas.

812. Pachiloma verticillata R. Phaiosperma or Polytenia do Raf. herb. p. 77. Stem fistulose grooved, branches whorled rigid, leaves alterne and whorled bipinnatifid, pinnules cuneate sublaciniate; involucels 1-3 linear, fruits obovate-found in 1823 in Glades of West Kentucky, vernal, sesquipedal, a very distinct and singular sp. by the whorled habit, fruit similar to the last by the edges \& c, but not regularly elliptic broader above and thus obovate, hardly striate in the central hollow.

I have yet several doubtful and rare ombelliferous plants from Florida, Alabama, Kentuky, Illinois and Arkanzas, which require further examination. My N. G. Orimaria was described in Atlantic Journal, in my Herb. Raf. p. 78 are 3 new Cherophyl um and 2 new Archemora. My G. Ptilimuium of 1818 has since 
been called Discopleura by Decandole, my Pt. junceum disc. 1823 in West Kentucky is perhaps a Leptocaulis. My'lhaspium tenufolium R. herb. p 78 is neither of that G. nor a Zizia, but probably an Archemera also. The Ferula villosa which has been united to 4 or 5 genera, must perhaps form a peculiar one which I have called Scadiasis. My G. Cyrtospermum, Lomatium, Cymospermum, Osmorhiza, Marathrum or Adorion, have been either adopted or illustrated by Decandole. I now pass to the Eryngides that are a fanily distinct although akin to this.

813. STREBLANTHUS Raf. atl. j. 1833 p. 149. Flowers monoical in separate heads. Involucre 4-6phyle, folioles unequal entire, phoranthe cylindrical papillose, male fl. in ovate heads apetalous, calix $\mathbf{4}$ fid,stamens 4 subsessile, female flowers in oblong heads, calix adherent 4 dentate persistent, pistil obovate punctate, petals none or deciduous, styles 2 filiform persistent, stigmas capitate. Fruit crowned bipartible in 2 seeds convex scrobiculate. Anmual herbs smooth prostrate, leaves opposite simple, heads axillary.-This character is taken from the first sp. but the $G$. probably contains many sp. and may be modified to comprize them : all the Eryngiums not perennial nor stiff, nor with alternate stiff leaves, must be examined well, and may perhaps belong here although some sp. may be polygamous, others with 5 stamens occasionaly. It forms now a striking $\mathbf{G}$. of ERYNGIDEs by the monoical apetalous tetrandrous flowers. The Er. cervantesi of Mexico E. tenue or gracile, balduini, prostratum of the Southern States may belong thereto. The name means deceitful flowers. 
814. Streblanthus auriculatus Raf. as above. Stems filiform flexuose, leaves subsessile, lower petiolate ovate lanceolate acuminate gashed or with 1 or 2 auricles, heads axillary solitary pedunculate-In the Western glades of Kentucky, flowers estival bluish, stems a foot long quite weak, leaves commonly with some notches, auricles une'ual when double, involucres linear, papillas of 1 .horanthe very short.

815. Streblanthus h iterophylus R. Eryngium prostratum Nut. stems filiform flexuose, leaves petiolate ovate elliptic and rounded, obtuse retuse or subacute entire, the upper sometimes auriculate, heads axillary solitary pedunculate-found in Arkanzas by Nuttal, and a real Streblanthus very similar to the last, chief difference the great diversity of the leaves, quite entire. The Eryngium gracile of Elliot appears to answer to this species.

816. Streblanthus humilis R. Eryngium gracile Tor. not Bald. E. balduini Spr. Dec. smooth suberect dwarf, lower leaves petiolate ovate acute dentate, upper sessile lanceolate often triparted. heads axillary and terminalfrom Tampa Bay in Florida, sent me by Torrey for the next, quite different, only 3 inches high, involucres linear as long as heads, flowers bluish quite similar to the two last.

817. Subgenus KLONION Raf. differs by the phoranthe convex with stiff subulate chaffs like bracts longer than flowers, and no involucre but those outer bracts, $\mathbf{4}$ or $\mathbf{5}$ concave petals. - Here there is an approxination to Eryngium, the plants are stiffer, the flowers spinescent, but there is no perianthe or involucre, the leaves are still opposite, the roots annual, there are some male flowers, and many have only 4 sta- 
mens and petals. The name was an old Greek one for Eryngium.

818. Strebl. or Klonion gracile R. Eryngium gracile Baldw. in Coll. herb. stem slender costate, leaves all tripartite, segments lanceolate or cuneate entire, hardly acute, heads spinescent pauciflore.-A very distinct sp. from Florida, detected by Baldwin; but Elliot having mistaken it, another has been called by his name, see 816. I describe the original specimens labelled by Baldwin. Many stems semipedal simple probably prostrate, but stiffer than in others, axils of leaves often foliose, peduncles equal to leaves, heads flattened with few flowers, some stiff spinescent chaffs at the base instead of a perianthe, flowers white.

810. Strebl. or Klonion tenuifolium $\mathbf{R}$. Eryngium polycephalum Baldw. in Coll. herb. stems erect dichotome filiform grooved, all the leaves tripartite, segments linear entire; heads axilary and terminal minute ovate.-In Florida likewise, another very peculiar sp. more slender than the last, but diffusely branched, with remote slender leaves, only 3 to 6 inches high, with many small heads of white flowers.

820. ATIRSITA Raf. calix campanulate 5 fid subequal, corolla campanulate 5lobed subequal, stamens 2 short not exerted, anthers globose, ovary depressed, style very short, sțigma emarg. capsule 2locular? oligosperme. Scapose flowers capitate.-By a most extraordinary blunder of Nuttal and Collins, this apparently $\mathbf{N}$. G. was referred to Eryngium! by them, altho' it has the habit of Plantago: the ripe fruit is required to settle accurately the family, and all the characters must be verified on the living plant, as I would not destroy my two specimens 
by examining many flowers; but $I$ venture to deem it a N. G. near Veronica and Amphianthus of Torrey. The name was an ancient one of Plantago of which it has quite the habit.

821. Atrisita pumila Raf. Eryngium gracile! Nuttal, Er ! plantaginaum Collins, leaves petiolate and subsessile, ovate smooth, uninerve, unequaly dentate or gashed, scape shorter than leaves terete villose, head ovoid-collected in Árkanzas by Nuttal, leaves and scapes hardly over one inch long, leaves variously cut, sometimes nearly entire, with few or several teeth, scape thick very short, head small, without any visible bracts, calix and corollas obtuse, corolla hardly longer white, annual, vernal. One of my specimen appears a variety serrata, leaves subsessile subserrate, scape not longer than the head.

822. Veronica perfoliata R. Leaves lanceolate smooth acute subserrate, base connate; racemes axillary pedunculate pubescent, flowers fastigiate or geminate, bracts lanceolate as long as pedicels, calix segments equal ovate acute.-Florida, mistaken for a Jusicia by Collins, near to $\boldsymbol{V}$. anagallis, but a larger plant, leaves 3 or 4 inches long, not entire but remotely serrate, racemes not much longer, flowers only above rather crowded, corolla blue hardly exceeding the calix.

823. Veronica connata Raf. atl.j. 150. erect smooth, stem fistulose, leaves connate lanreolate entire acute ; racemes axil. divaricate elongate lax, bracts linear half of pedicels.-West Kentucky near waters, annual, vernal, akin to $\boldsymbol{V}$. scutellata, but broader and shorter leaves uncial, capsules bilobed compressed. In this 
and the last sp. the opposite leaves are realy connate.

824. Veronica diffusa R. precox atl. j. 79. stem diffuse compressed pubescent, lower leaves opposite, upper alternate, on short petiols, ovate and rounded, serrate laciniate trinerve; peduncles axil. solitary longer than leaves, capsule compressed emarginate,-Annual very early vernal blossoms blue and delicate in March and April, native of ... naturalized on the Schuylkill near I'hiladelphia. I had called it $\boldsymbol{V}$. pre$\operatorname{cox}$ in 1832, but there is another sp. of that name. Stems often procumbent weak, one foot long, leaves small, flowers pretty large, peduncles long, capsules drooping, calix with ovate equal segments. Very different from $\boldsymbol{V}$. chamedrys and teucrium to which it is however related.

825. Veronica sparsiflora Raf. atl. j. 79. stem erect simple smooth terete solid, leaves opposite sessile cuneate entire obtuse smooth, upper oblong; raceme terminal elongate lax pubescent, flowers scattered, bracts linear obtuse, pedicels filiform longer, calix segments oblong obtuse, two shorter, capsules bilobed subcompressed-a very distinct sp. from Arkanzas and Missouri, seen alive in gardens, annual, stem 1 or 2 feet high, leaves 1 or 2 inches, lower almost petiolate, flowers vernal large handsome purplish blue. By the calix quite unequal it belongs to my subgenus Becabunga.

826. Veronica moldis Raf. erect softly villose, leaves opposite sessile ovatoblong serrate acute, lower and radical oblong and cuneate nearly entire; raceme terminal bracteate densiflore, bracts lanceolate equal to flowers, calix lanceolate unequal.-From Origon seen alive 
in gardens, entirely eovered with a soft velvety pubescence, but not cinereous as in next, stem commonly pedal, radical leaves cespitose variable larger some nearly obovate and obtuse, flowers vernal large handsome pale blue, style clavate, capsule not seen.

827. Veronica cinerea Raf, erect cinereous villose, leaves alternate oblong cuneate acute, subcrenate in the middle, flowers terminal spicate very dense sessile, bracts lanceol. equal to calix, segments unequal ovate obtuse.-From Origon also, pedal, leaves uncial, spike terete, corollas dark blue or purple (almost brown in my specimen) contrasting with the canescent calix, stamens very long. Akin to $\boldsymbol{V}$ incana but distinct by leaves \&c, and also to the two preceeding, all three yet very different, this not at all racemose.-I have many other doubtful Veronicas of North America, and this Genus yet requires revisal in sp. as $I$ did in Genera in Flora Telluriana. As I have 50 or $60 \mathrm{sp}$. of various parts in my Herbarium, I may hereafter write their monograph.

828. ODACMIS Raf. calix 4parted deciduous, 4 small petals nearly similar and equal, stamens 4 hypogynous, filaments short, anthers bilobe. Ovary free globular umbilicate, styles 2 extremely short. Capsule membranaceous utricular globular bilocular, with 2 or few seeds, opening by the concave umbilic above. Creeping anmual herb, leaves and flowers fasciculate. - A very singular $\mathbf{N}$. $\mathbf{G}$. of my nat. order Isostinia, and probably my family Galenidi, with Galenia, Florkea \&c; also akin to EMPETrenes which only differ by a berry as in Empetrum and Phytolaca. 'The habit is very pe- 
culiar, and the name is derived from the uncinate teeth of leaves.

829. Odacuis Fascicularis R. smooth, stem creeping angular, leaves petiolate fasciculate, subreniform with large hooked teeth, base subtruncate without teeth, peduncles of flowers longer than petiols.-From Florida, collected by Kin or Ware, anonymous in Coll. herb. small plant prostrate, fascicles of leaves remote alternate, leaves with many nerves and only half inch wide. Flowers greenish, sepals $\mathbf{4}$ ovate acute, petals 4 elliptic obtuse yellowish not longer than calix.

830. BUINALIS Raf. dioical. Calix deeply 5fid persistent, base turbinate with 5 tubercles at the clefts, segments flat edged and crowned by a thick colored membrane. Corolla none, male $\mathrm{fl}$. with 5 stamens perigynous inserted on the calix short filiform fertile, and 5 alternate sterile without anthers, sometimes lacking. In female fl. ovary ovate, style filiform elongate, stigma simple. Fruit Akena ovate smooth monosperm. Stem articulate, leaves opposite sessile entire stipnelate, flowers fascicled-a new G. of family Acrry ranthides differing from Amaranthides by a single style and stigma. It differs from my G. Steiremis in fl. tellur. by dioical single calix, free stamens, of c. It has the habit of Herniaria and Anychia to which it is also related but differs by dioical flowers and single style, besides the calix not angular nor acute \&c. The name was an old latin one of Herniatia.

831. Buinalis flomidana Raf. Herniaria Americana Coll.herb. Anychia floridana Baldw. do-prostrate diffuse subdichotome fuscate, leaves sessile cuneate or obovate, obtuse or sub- 
acute, entire thickish ; flowers sessile terminal in leafy ramulose fascicles.-In the sands of Florida, found by Baldwin, perennial, almost suffruticose, stems 3 to 6 inches long very ramose, stipules scariose ovate acuminate, leaves small 2 or 3 lines long quite brown in the dry specimens; flowers minute dark purple margined of white, the ends of segments truncate almost retuse forming a vault but not a hood,these flowers are at the ends of the small branches crowded with sma!l leaves and stipules.

832. ANYCHIA. Mx. The plants of this $G$. and others akin forming a small natural group, have been blended with the G. Queria, Paronychia, Achyranthus \&oc, their synonymy and sp, are in utter confusion. Having shown to 'Torrey $4 \mathrm{sp}$. widely different in habit, leaves and flowers! he pronounced them all varieties of Queria canadensis! They require as yet a monograph, and must be divided into 2 or 3 Genera by the stamens, that must all be examined again, since Michaux and Nuttal differ about them. I regret that I did not examine all mine when met alive. Meantime I will divide them into 3 subgenera or Genera, and add some new species.

Subg. Arycrin calix 5 parted persistent urceolate or segments angular or nervose on the back, end hooded acute. Stamens 3 to 5 fertile, none sterile? 2 short styles, capsule utricular monosperm. Anmual dichotomous plants, leaves opposite sessile with scariose stipules, flowers in dichotomies, uzcolored.

8;3. Argyrocona Raf. Paronychia Nuttal not Tourn. Juss. difference, calix oblong, segments cuspidate nervose on the back. Stamens 5 fertile, 5 sterile? style bifid 2 stigmas capi- 
tate. Perennial plants, stems simple, flowers terminal corymbose.

834. Plagidia Raf. difference from Anychia, calix conical pentagonal, segments unequal acuminate not hooded, stamens $\mathbf{5}$ fertile. Style bifid, 2 stigmas acute. Annual plants? leaves obliqual broader, flowers in dichotomies. The name derives from the double obliquity of opposite leaves. All these genera belong to Amaranthides.

835. Anychin divaricata R. stem decumbent puberulent very branched and divaricate, leaves oblong acute smooth, stipules ovate acute, flowers crowded striate sessile segments of calix nervose.-A very distinct $\mathrm{sp}$. blended as usual with Queria or A. canadensis, branches so divaricate as to be sometimes almost reflexed, leaves 3 lines long one broad, flowers small quite crowded at the end of branchlets. Found from the Alleghany Mts. to Kentucky on hills, estival, stems spreading 6 to $\mathbf{1 0}$ inches.

836. Anychia lateralis R. atl. j. 16. stem erect divaricate pubescent, branches unilateral, leaves remote linear oblong acute, stipules lanceolate acuminate, flowers sessile striate often lax.-On the arid hills of Kentucky, possibly a var. of last, but smaller 1 to 2 inches high or long, leaves and stipules narrow, flowers similar ostival.

837. Anychia fastigiata R. atl. j. stem erect pubescent, branches fastigiate, leaves linear cuneate acute adpressed granular beneath, stipules lanceolate, flowers few on short peduncles, calix pentagonal hardly acute.-On the knob hills of Kentucky, habit so different from 835 as to indicate a sp. a very small plan 1 to 3 inches high, leaves narrow, flowers w; 
segments hardly acute, not nervose. A var. my A. conferta atl. j. has the same habit, but flowers crowded, leaves subserrulate. I have several other var. of this Genus, my A. polygonoides is the 2d (A. canadensis or Nuttal and most of our botanists,) it is quite erect with narrow longer leaves often uncial patent subciliate, flowers nervose acute. The $A$. capillaris $\mathbf{N}$. is the real $\boldsymbol{A}$. dichotoma of $\mathbf{M x}$. quite distinct by broad leaves elliptic, stem filiform smooth, flowers as in 837.

338. Anychia nudiflora R. smooth, erect, branches unilateral, leaves linear acute; flowers in terminal naked cymes with few leaves, pedunculated, caliculated by radiate oval stipules, calix nervose hardly acute-from Fiorida collected by Kin, a small plant forming a passage to Argyrocoma, but flowers as in Anychia and leaves small.

839. Argyrocoma mmercata Raf. Paronychia argyrocoma $\mathbf{N}$. Anychia do Mx. has crowded leaves and flowers narrow linear elongate adpressed imbricate, flowers with imbricate silvery bracts or stipules. - While the A. dichotoma which is Achyranthes do Linn. lllecebrum do Wild \&oc, has flowers corymbose with lax and less silvery bracts; both have the calix long with very thick dorsal nerves, end very acuminate. A third sp. is Par. sessiliflora N. but his $\boldsymbol{P}$. herniarioides is probably of next Genus.

810. Pragidia rufa Raf. Anychia herniaroides $\mathbf{M x}$ ? dichotome scabrous, much branched fastigiate entirely rufous, leaves obliqual crowded elliptic mucronate ciliolate, stipules lanceolate acuminate, flowers solitary.-Described from a specimen from Florida anony- 
mous in Collins herb. apparently the plant of Mx. but I cant be certain as he omitted the singular obliquity of the leaves almost as in Chamasyke, and the striking rufous color almost like snuff of the whole plant even the stipules; about 3 inches high, leaves 3 lines long, quite obliqual at the base altho' sessile, flowers few and small.

841. AMORGINE Raf. calix 5parted persistent caliculate, segments obtuse, convex outside, canaliculate inside, 3 or $\mathbf{4}$ small scales at the base. Corolla none. Stamens 5 free short inserted on calix, anthers round, no sterile stamens. One style entire, stigma simple obtuse. Capsule utricular monosperm. Dichotome articulate, leaves opposite with stipules, flowers terminal corymbose. - Another new G. partaking of habit of Anychia, but flowers as in Argyrocoma yet colored and ciifferent with single style as in Buinalis, Cadelaria \&c, of family Achyrantimes. The name was one of Dioscorides for Parietaria.

842. Amorgine albescens Raf. smooth erect dichotome, leaves shorter than internodes linear cuneate acute, stipules lanceolate; flowers corymbose crowded sessile naked albescentFlorida, anonymous in Collins herb. probably a larger plant than akin, stem rigid, leaves elongate almost like Argyrocoma uninerve drying black like them; flowers forming a compact corymb, sessile without bracts nor leaves except the short calicule, of a dirty white color or tinged of incarnate, $\mathbf{A}$ very distinct sp. and even G. overlooked or mingled in our Achyranthes, which form many Genera, Steiremis, Caraxeron, Phylepidum \&c for which see my flora 
Telluriana, where they are described, and I add here another new Steiremis.

843. Steiremis ciliata R. Illecebrum polygonoides Mx. Coll. herb. not of others? Stem prostrate pilose, leaves opposite unequal. petiolate obovate rounded obtuse, base ciliate ; flowers in small axillary glornerules, bracts and segments of calix scariose nervose ovate acuminate-in Florida and Georgia on Sea Shores, also in Louisiana, stems pedal with long soft hairs, the pair of leaves constantly unequal in size about 1 inch long, glomerules of flowers not longer than petiols whitish or fulvous. This is not the Achyranthes repens of Elliot, which is the type of my Steiremis, that has lanceolate leaves; it is nearer my St. sessilifolia fl. tellur. 552, of Africa and Spain, but with sessile acute leaves. The leaves appear thickish and when dry have vermiculate spots almost transparent when held to the light.

844. BLUTAPARON Raf. calix double scariose persistent, external 3parted unequal, internal 5 parted unequal, segments flat not nervose. Stamens 5 free, hypogynous. Ovary quite flat round, 2 styles, stigmas obtuse, capsule lenticular monosperm. Leaves opposite not stipulate, flowers terminal capitate.-A very peculiar G. of not family Amaranthides with the habit of Gomphrena, but quite different from it, and from Illecebrum to which it had been united by Linneus and others. The name is abridged from Bulutulaparon old latin name.

845. Blutaparon breviflorum Raf. Illecebrum vermiculatum $\mathbf{M x}$. and $\mathbf{N}$. Amer, smooth erect, leaves sessile linear cuneate acute thick, heads of flowers globose or depressed, segments of calix oblong or elliptic obtusc. On 
the sea shore of Florida collected by Dr. Baldwin, the good specimen in Coll. herb. has enabled me to fix this Genus and sp. very different from that of S. America. Stem erect terete, leaves uncial commonly longer than internodes, heads of flowers quite small depressed pauciflore, flowers white seariose, two segments of the inner calix larger elliptic making the flowers appear compressed, fruit discoidal flat lenticular, perhaps bivalve when ripe. I must add the linnean sp. for contrast.

846. Blutaparon repens Raf. Illec. vermic. L. and of S. Amer. smooth creeping, leaves sessile linear carnose semiterete, heads of flowers oblong-Brazil, Guyana, Curazao, pedal, leaves like hyssop sometimes verticillate by 4 .

Thus I was right when in the first volume article Achyranthes, I stated that the plants akin thereto were in utter confusion: our botanists seldom verifying the Genera of their sp. We have yet the G. Oploteca, with my Xerandra, see fl. tel. 562, some real Celosias, and Gomphrena naturalized, and my Adoketon see first part, to which add that the Illecebrum alsinefolium of Scopoli is another sp. different from my Ad. saxatile.

847. Corispernum pilosum Raf. pilose, stem angular, leaves alternate linear elongate uninerve, flowers in axillary glomerules ovate, sepals scariose pilose ovate acuminate trinerve. -Found by Kin in Florida, realy of this $\mathbf{G}$. hitherto not known as American, whole plant fulvous in the specimen and with scattered hairs, leaves 1 or 2 inches long narrow', glomerules subovate, crowded and capitate at the top flowers imbricate glumaceous squarrose, 2 sepals equal large, enclosing-1 single stamen fili- 
form, anther round, seeds ovate lenticular.Let it be remembered that these discoveries of Kin and Baldwin had been made 20 and $\mathbf{3 0}$ years ago, laying dormant like those of Bartram in herbals.

POLYGONUM and akin Genera.

This Genus the shame of botanists as belonging to 10 linnean classes! was illustrated in my flora tellur. 401 to 434 . I have described there many N. Amer. sp. and the new Genera Tracaulon, Spermaulaxen, Stopinaca, Antenoron, Tovara, Pleurvstena, Chulusium, Peutalis \&c. 1 shall merely add some other remarkable new species formerly included in Polygonum and Rumex divided also in 7 Genera 576 to $582 \mathrm{fl}$. Tellur. Having in my herbal about $100 \mathrm{sp}$. of these $\mathrm{G}$. akin and reformed, I may yet revise the whole.

848. Peutalis or Mitesia ligularis Raf. smooth filiform, leaves lanceolate acute, sessile sheaths simple obsolete, racemes axil. and terminal filiform pauciflore, flowers remote, sheaths tubular ligulate obtuse equal to pedicels.- $\mathbf{A}$ curious little species, half pedal, deemed Polyg. mite by Collins, very different, leaves few uncial quite smooth, racemes with 3 to 7 flowers, each out of a singular sheath, calix incarnate 5lobed seeds lenticular. A palachian Mts. of Carolina, Iron Mts. found by Lyons? IMitesia may be a subg. of Peutalis, this appears a Peutalis by seed, I cant count the stamens usualy 6 in Peutalis and Mitesia, but with 3 styles and trigone seeds in Mitesia.

849. Peutalis or Mitesia floridana Raf. Polyg. N. sp. Baldw. smooth erect simple,leaves sessile narrow lanceolate nearly obtuse inargin rough, sheaths tubular bristly, flowers in a sin- 
gle terminal spike, slender pauciflore, adpressed subsessile in the bristly sheaths-Florida found by Dr. Baldwin and deemed new by him, stem pedal, leaves biuncial, spike uncial 7 flowersI have also the M. hirsuta Raf. polyg. do of Walter, Elliot \& c collected by Baldwin in Florida, a singular sp. covered with long fulvous hairs, leaves broadly lanceolate, sheaths of flowers tubular obtuse nearly as in $\mathbf{M}$. ligularis.

850. Peutalis or mitesia divergens $R$. smooth decumbent ramose, branches divergent or reflexed, leaves sessile narrow lanceolate acute margin smooth, sheaths scariose ciliate, racemes terminal filiform, sheaths valvular shorter than pedicels.-Dicovered 1818 in Kentucky, deemed Polyg. divaricatum then, but having obtained that plant it is quite different. Stem 2 feet long, branches diverging like a $\mathbf{T}$ not like a $\mathbf{Y}$, even often reflexed, leaves equal to internodes $\mathbf{2}$ inches long very narrow, spikes as long, flowers white estival, seeds trigone and thus a true Mitesia.

851. Peutalis or Heptarinia longifolia Raf. smooth erect ramose, leaves narrow lanceolate very long acuuinate sessile, margin rough, sheaths scariose ciliate, racemes slender filiform spiked, sheaths tubular subciliate-Mts. Alleghanies and hills of Pensylv. bipedal, leaves 5 and 6 inches long, only half inch broad, flowers incarnate small autumnal, spikes uncial often geminate and interrupted at base. Flowers as in Hept. orientalis with 7 stamens, 2 styles exerted, stigmas capitate, seed lenticular.

852. Peutalis (discolenta) scabra Raf. stem dichotome erect subangular, rough above chiefly in the peduncles of spikes, leaves petiolate lanceolate acuminate, margins and nerve 
rough, sheaths scariose mutic; racemes many pextuncled ovate and ablong, flowers fasciculate crowded.-One of the sp. akin to P. D. lapathifol. bipedal, very branched, leaves 2 or 3 inches long, spikes uncial or less, with a rough pubescence, flowers estival incarnate, seeds round flat with a hollow in each side and a thick obtuse edge. In Kentucky, Illinois \&c. Tho Discolenta scabra ft. tel. 430 is a very different plant, perbaps even a Dioctis, and heing smooth, it was by a mistake $I$ described it for this : it must be called P. or D. punctata being quite so aud probably P. punctatum of Elliot.

853. Peutalis heterophyla Raf. smooth erect, lower leaves petiolate, oboval, or elliptic ciliate sometimes retuse, broadly lanceolate, upper subsessile narrow, all glaucous beneath and with smooth margins, sheaths pilase ciliate ; racemes short pauciflore compact, sheaths scariose smooth.-Singular sp. disc. 1824 in Alleghany Mts. of Virginia, percnnial, lower leaves small uncial quite ciliate, medial large triuncial, ciliate only at base, upper not ciliate; flowers of a dirty incornate geminate in small racemes, seeds lenticular ovate obtuse.

854. Peutalis glomerata Raf. smooth decumbent ramoso diffuse, leaves sessile shortly lancuslate obtuse, margin smooth, sheaths mutic, flowers in numerous terminal glomerules, like little heads, sessile or peduncled pauciflore, flowers subsessile -in Penusylvania and Virginia, annual, branches and leaves crowded, stem spreading about one foot, leaves small uncial, heads of flowers axil. or terminal, often interrupted divided in glomerules, flowers autumnal greenish white, seeds lenticular ovate, edges obtuse. 
855. Peutalis rolystachy a Raf. smooth erect ramose, leaves sessile lanceolate acute margin rough, sheaths scariose tubular aristate; racemes paniculate branched, slender and lax, flowers commonly geminate, pedicels longer than sheaths-from Pennsylv. to Kentucky, stem bipedal with a profusion of spikes, leaves 1 or 2 inches long, racemes as long axilary and terminal, flowers autumnal white, seers ovato oblong compressed lenticular edge thick.

856. Peutalis parustris Raf, stem simple smooth, leaves sessile lanceolate acute erect, with adpressed hairs on both sides glaucous boneath, sheaths tubular ciliate; spikes terminal pedunculate 1 to 3 , filiform, flowers sessile, sheaths as long as flowers-a very pretty sp. growing in ditches and swamps from Vermont to New Jersey, deemed Polyg. punctatum by some botanists, but not at all punctate, and very different from the 2 punctate sp. of the North and south. Pedal, leaves biuncial, flowers rose color or incarnate, spikes slender uncial, seeds lenticular, stamens 6 . It must be recollected that Chulusium has 5 stamens, Peutalis 6, Heptarinia 7, Dioctis 8, and Mitesia a trigone seed. As it is often difficult to count the stamens and some deem them variable, all those with lenticular seeds and 2 stigmas might be united as subgenera to Peutalis that answers to Persicaria which is not the Peach Tree! Persica.

837. Polygonum squamosum Raf. smoath erect terete ramose, branches short divergent, leaves and sheaths imbricate, leaves linear oblong obtuse short, sheaths scariose scaly lanceolate acuminate; flowers axillary sessile-in West Kentucky disc. 1818, habit quite peculiar 
by the scaly sheaths, leaves minute 2 lines long, flowers almost hidden in the scales as long as them and the leaves, estival.

858. Polygonum rubricaule R. smooth, stems erect cespitose red simple angular striate, leaves minute few remote sessile deciduous linear obtuse, sheaths scariose lacerate fimbriate, flowers axillary sessile-hills of Pennsylvania,autumnal,very distinct by stems and sheaths, leaves sometimes only at end of branches and then imbricate, stems only 2 to 6 inches high, sheaths red, ciliate of white, flowers greenish and white.

859. Polygonum nudiflordm Raf. smooth, stem angular ramose diffuse flexuose, base aphyllous, leaves terminal sessile oblong lanceolate acute, sheaths scariose truncate mutic, flowers axillary to the lower sheaths and not to the leaves-in Alabama, stems semipedal, the lower leaves fall very soon and thus leave the flowers naked, leaves half inch long, flowers commonly geminate longer than sheaths, calix urceolate green obtuse equal to seeds.

860. Lapathon sylvaticum Raf. Rumex do An. nat. 91. Root tuberose, stem angular striate simple, leaves petiolate ovatoblong flat entire acute at both ends: raceme elongate naked articulate, outer calix segments oblong obtuse small, inner segments ovate laciniate, one granular - Western Kentucky and Illinois in woods discovered 1818 described 1820 as a Rumex; but it belongs to the G. Lapathon of Tourn. Ad. which $I$ have rectified thus, calix double unequal, inner larger laciniate, one or mare valves granular, stamens 6 , styles 3 . Pedal, estival, root fusiform, radical leaves not larger than stem leaves. 
861. Rumex or acetosa meterophyia Raf. root tuberose, radical leaves ovate and rounded, hastate or entire, acute or obtuse, stem leaves remote petiolate ovate acute repand, racemose pauciflore-Apalachian Mts. of Virginia, root oblong rugose, stem simple subangular, leaves all petiolate, the radical smaller, not hastate nor sessile on the stem, flowers but few and not in interrupted spike.

862. Rumex or acetosa integrifolia Raf. Root creeping, stem striate simple, leaves all petiolate orate or lanceolate entire acute, radical small ovate, caulinar few lanceolate, raceme filiform almost simple pauciflore-in Kentucky, semipedal, root not tuberose but perennial with fibres, leaves thin radical very small, very few on stem, flowers few remote. Although akin to the last, the root is quite different horizontal slender as in next.

863. Rumex or ACETosa Agrestis Raf. Rumex acetosella of many bot. root creeping,stems grooved cespitose, all the leaves petiolate oblong or lanceolate hastate; spikes paniculate filiform interrupted.-This is our common Sorrel, of Europe and America, 6 to 12 inches high; but there are other blended sp. in Europe, since I have at least 3 others and one of them hardly different from $\boldsymbol{R}$. hastatulus of Baldwin which I have also, his own specimen from Red River Arkanzas. I will describe them hereafter, I now merely give their striking differences and also of 2 Rumex acetosa!

1. $R$. A. hastatula R. upper leaves sessile linear entire elongate. Furope and Red River.

2. $R$. A. bidentata $R$. leaves bidentate or entire oblong and linear, from Greece and Italy. 
3. $R$. A. angustata R. leaves linear lanceolate sagittate. Sicily and Creta.

4. $\boldsymbol{R}$. A. olitoria R. Grarden Sorrel, leaves oblong sagittate, upper sessile and narrow.

5. R. A. amplexicaulis R. Leaves ovate sagittate sessile amplexicaule. Eastern Europe all in my herbal.

864. Lriogonur annuum Coll. herb, annual, stem simple cinereous naked above, leaves alternate sessile oblong or cuneate acute white tomentose beneath; umbels trifid, perianthes pedunculate multifl. campanul. 5 dentate tomentose.-Salt $\mathbf{K}$. of Arkanzas probably found by Nuttal, pedal and bipedal, leaves uncial, umbel small branches pauciflore, with a flower in center. This beautiful N. Amer. G. is now greatly increased although only one known to Michaux: I shall now add 4 sp. to it.

865. Eriogonum hateriflorum Raf. stem simple white tomentose aphylous and flocose above, leaves alternate lanceolate acute sessile, flocose above, tomentose beneath : umbel trifid, branches dichotome, flowers unilateral, perianthe subsessile campanul. subentire 2-3flore.Plains of Missouri and Arkanzas found by Bradbury and Nuttal, anonymous in Coll. herb. stem bipedal without leaves above, the white wool partl; flocase appearing like little warts or wrinkles, leaves 2 inches long, umbel multiflore, flowers small.

866. Eriogonum diorcum Raf. suffruticose, dioical, silky white, leaves petiolate verticillate cuneate lanceolate obtuse white beneath, umbel with 6 involucres oblong sessile, perianthes glomerate sessile with obtuse teeth-found by Bradbury on River Platte, leaves 2 inches long, flowers in a double umbel multifid. My speci- 
men from Bradbury is apparently only male. 867. Eriogonum longifolium Nut. in Coll. herb. stem simple cinereous, radical leaves petiolate cuneate elongate smooth above, white tomentose beneath, stem leaves sessile linear, umbel dichotome, flowers lateral glomerate sessile, perianthe campanul. 5-6fid obtuse.Ozage prairies (Nuttal) in Arkanzas, bipedal, lower leaves 6 to 8 inches long, becoming gradualy less and very small above, flowers rather dichotomous than umbellate in lateral clusters almost sessile, perianthe deeper cut than usual. EVOLVULUS and akin

I have several $\mathbf{N}$. American sp. that would be reduced to Evolvulus by habit and calix equal ; but this Linnean Genus must form many see fl. tellur. 1046 to 1054; while my specimens are often deficient in the flowers so as not be reducible easily to those genera, based on the shapes of corolla, styles \&c: probably however most belong to my Stylisma of $181 \%$.

868. STYLISMA R. 1817. ft. tell. calix simple subequal, corolla campanulate subentire or sub-tendentate, filaments 5 subequal villose at base, anthers sagittate, disk annular, style biparted, 2 stigmas globose, capsule 4locular 4sperme.-Perennials, peduncles axillaryThe true Evolvulus differs by corolla rotate 5 fid, capsule 2locular 4valve disperme, 2styles.

869. Stylisma heterophyla Raf. Convolv. tenellus Muhl. in Coll. herb. C. trichosanthes Lec. in do, not of others-stem erect terete pubescent, leaves subsessile nearly smooth, lower obovate obtuse, upper elliptical obliqual acute, peduncles patent uniflore double of leaves with 2 unequal oblong bracts, calix smooth, segments ovate acute-Florida and Georgia, a very dis- 
tinct sp. stem pedal, leaves small semiuncial, peduncles uncial, corolla nearly entire, stamens subequal, styles deeper cut, stigmas really globose. Evidently not the C. tenellus of Elliot.

870. Strusma Elliptica Raf. stem twining terete pilose, leaves petiolate elliptical hardly pubescent, base subcordate, end obtuse mucronate, peduncles uniflore subequal to leaves with two minute bracts, calix smooth, segments ovate acuminate, capsule hirsute-sent me from Alabama and Georgia, trailing or twining for 2 or 3 feet, leaves uncial, style bifid, 2 globose stigmas. My Styl. sherardi, Convolv. do Pursh. Elliot, a doubtful plant differs from this by leaves retuse and sessile flowers.

871. Struisma peduncularis Raf. Convolv. tenellus Lin? Elliot \&c stem flexuose pilose, leaves subpetiolate elliptical obtuse mucronate ciliolate, base subcordate, peduncles elongate 2 or 3 times the length of leaves 2 or 3 flore, calix smooth, segments ovate acuminate bracts minute, capsule bearded-Alabama and Florida, near the last but larger leaves, stiff long peduncles, style deeply divided, stigmas obtuse. The Conv. tenellus of Elliot only differs from my specimens by peduncles 3-5flore, calix ciliate f.c.-But his C. trichosanthes my tylisma do, differs much being quite tomentose \&c.

Having obtained both the Evolvulus sericeus of Cuba collected by Jalambic and that of Florida from Baldwin; they appear alike, except that the stem is nearly smooth in the Cuban specimen, pilose in the Floridan.

872. DARLUCA Raf. calix 5parted equal persistent, corolla tubular hirsute outside irregular subbilabiate, lips 2 and 3lobed. Stamens 
5 ? unequal, anthers bilobe. Ovary villose, style villose bifid, stigmas simple. Capsule villose : Zlocular 2sperme. Habit of Stylisma - a very singular Genus nearly alike Stylisma and Evolvulus in habit, leaves, calix, style \&c, but with irregular corolla, singular anomaly of the Convolvulides, but already partly found in $\mathbf{m y} \mathbf{G}$. Doxema $1020 \mathrm{f}$. tellur. perhaps however of another family. Dedicated to Darluc, author of the Natural history and botany of Provence, who I think has been overlooked by all dedicators of Genera, if otherwise I substitute the name of Neleixa mg. not smooth outside.

873. Darluca prostrata Raf. prostrate pubescent, leaves subsessile oblong obtuse or acute at both ends, peduncles uniflore incurved longer than leaves, with 2 alterne linear bracts, calix pilose, segments ovate lanceolate acute.-In Florida, found by Ware, anonymous in Coll. herb. with Evolvulus, but irregular corolla noticed. Stems terete elongate nearly simple, leaves semi uncial narrow oblong, peduncles subuncial, corolla very hirsute outside, capsule ovate inclosed in calix.

874. Evolvulus ! crneifolius R. fl. tel. 1046. erect smooth, leaves linear cuneate acute, peduncles uniflore pilose longer than leares, calix pilose linear capsule pilose longer than calixPine barrens of New Jersey, pedal, my specimen has no corolla and is in fruit which appear unilocular with one or two sceds, 2 styles persistent, stigmas obtuse. Probably a subgenus or G. Plesilia Raf. but the corolla and sta. mens must be described, the calix as in Stylisma.

As to the Convolvulus and Ipomea of Authors, they are illustrated at length and revised in my fl. tellur. 1001 to 1051 , being divided into 
many striking Genera, with several Amer. sp. introduced, I will merely add here two from Collins herbarium chicfly.

875. Iромea humilis Raf. Ip. heterophyla Col. herb. smooth, stem erect humble angular, leaves cordate palmate 5lolsed, lobes ovate and lanceolate acute, peduncles as long as leaves 1-2flore, 2 subulate bracts, segments of calix ovate acute ciliate, hairs curved-South Florida and Cuba, annual, root slender, stem semipedal, leaves small similar, flowers red, calix with singular cilia on the margin and back, white long and incurved. Very different from Ip. heterophyla of Mexico, a large climbing plant, with different leaves: both belong to the subgenus Hemilasis fl. tel. 1016 with very unequal calix. 976. Quamoctita multifida Raf. Twining, smooth, leaves multifid laciniate, base truncate sinusses obtuse, segments linear and lanceolate acute, peduncles 3-5flore equal to petiols, calix acute-a curious sp. deemed a garden hybrid, produced by $\mathbf{Q}$. coccinea and $\mathbf{Q}$. pinnata, leaves variously cut, few alike, some reniform with shorter cuts, flowers handsome large purple, tube clavate, limb flat stellate pentagone, stamens exserted. Seen alive in gardens, where sometimes spontaneous.

877. Panax lanceolamm R. Root slender, stem humble, folioles $3 \mathrm{t}$, subequal lanceolate acute sharply,serrate sessile, the lateral obliqual, umbel shorter than leaves-Mts. Alleghanies, blended by some of our botanists with $\boldsymbol{P}$. trifolium that has folioles ovate and obovate much smaller and umbel much longer than leaves. This rises 8 to 10 inches, folioles over one inch long narrow : root slender, annual? 8 leaves as usual. 
878. Parax americandm $R$. quinquefolium var. do R. med. fl. t. 71. perennial, root fusiform tuberose, stem streight, folioles 3 to 5 unequal, petiolate, 3 large serrate cuneate acuminate, two small at base subovate, sometimes lacking, umbel equal to leaves.-This is the famous American Ginseng found from Canada to Missouri, quite different from the Chinese or Tartarian sp. with 5 equal broad ovate leares! It has also some varieties, 1 obovatum with broader leaves unequaly serrate, but still acute at base, 2 elatum, very tall, 3 feet high, perhaps only old age. For a long account of this plant see my med. fl. 2. page 52

\section{ASCLEPIAS and akin}

879. Gonolobus birlorus Paf. Coll. heib. prostrate hirsute, leaves small cordate ciliate acute on short petiols sometimes obliqual ; flowers geminate, peduncles equal to petiols-on Red River in Arkanzas and Texas, remarkable by small leaves and flowers, one fourth in size of $\boldsymbol{G}$. hirsutus. flowe:s dark purple, lobes oblong obtuse: whole plant except corolla covered with soft white hairs.

880. Ansonia tenvifolia $R$. stem suffruticose ramose smooth, branches pubescent, leaves narrow linear uninerve quite smooth, margin revolute, end obtuse-Florida found by Kin. One of the $3 \mathrm{sp}$. blended in $\boldsymbol{A}$. angustifolia, which has leaves linear lanceolate, stem herbaceous pilose. The A. ciliata of Walter I have also and is quite distinct by flat leaves broader almost lanceolate quite ciliate with several small lateral nerves. There are $\mathbf{3}$ similar deviations In $\boldsymbol{A}$. Iatifolia with ovate acuminate leaves, $2 \mathrm{~d}$ with elliptic acute leaves, $\boldsymbol{A}$. elliptica, $3 \mathrm{~d}$ with lanceolate leaves which is $\boldsymbol{A}$. salicifolia. I have 
all six. This G. is usualy misprinted Amsonia by a mistake: see Smith.

881. Echites salicifolia $\boldsymbol{k}$. suffruticose erect, all the leaves subsessile lanceolate acute sometimes obliqual, glaucous beneath-in Florida, stems red, leaves 1 or 2 inches long; it differs from $\boldsymbol{E}$. difformis with unequal leaves mostly ovate acuminate, as Ansonia salicifolia from A. latifolia.

88:. Cynanchum microphylum Raf. climbing smooth, leaves opposite oblong acute base rounded, petiols very short, umbels axillary nearly sessile pauciflore-Florida, deemed an Asclepias in Coll. herb but very near Cyn. parviflorum, evidently of same Genus, stem filiform, leaves 2 to 4 lines long only, flowers minute shorter than leaves, calix 5dentate, corolla 5 fid obtuse.

883. Lyonsia cuspidata Raf. trailing smooth, lower leaves opposite, upper alternate, all linear flat remote, base acute sessile, end obtuse cuspidate, umbels axil. subtriflore subsessile, fruits subulate smooth-Florida, deemed Cynanchurn angustifol. by Collins, which is Lyonsia maritiina of Elliot, but that sp. differs by crowded opposite leaves acute canaliculate and thick, umbels-multiflore. This has stems filiform, leaves 1 or 2 inches long very narrow, follicles as long. Lyonia was a mispelling.

884. ANANTherix GRANDIFlora Raf. smooth stem flexuose grooved angular, leaves scattered sessile upper opposite oblong elliptic obtuse mucronate reticulate; umbels terminal corymbose -a fine sp. collected by Kin in Arkanzas, pedal and ultra, stem thick.with obtuse angles and deep grooves, leaves two inches long crowded, several terminal umbels 7-10flore pedunculate, 
flowers very large glaucous, segments of corolla patent ovate obtuse; deemed a Calotropis by Collins, but a real Annntherix and by no means a Stylandra N. or Podostima E. To the same Genus appears to belong Asclepias connixpns of Baldw. Elliot \&c which is very akin to this in leaves and flowers, but has stem terete and leaves opposite narrower, white ringed warts on the stem, I'll call it Anantherix verrucusa: my specimens are from Alabama. A. viridis $\mathbf{N}$. differs by leaves narrower thick pubescent, umbels lateral subsessile \&c.

985. OLIGORON Raf. Acerates Elliot. Sce my article Acerotis in first part. I have since divided them. My name is found in Dioskorides for an Apocynum. Acerates was bad derived from Acer and Aceras. This G. will be easily known by the sessile scattered leaves, the erect umbels and $\mathbf{5}$ small shining tips upon the staminal apparatus, auricles adpressed without appendages.

886. Oligoron longifolium Raf. Asclepias do Mx. Ascl. floridana Lam. Acerates longif. E. -Pubescent, leaves linear lanceolate elongate trinerve, umbels peduncled multiflore, auricles shorter than stamens-Carolina to Florida and Arkanzas, leaves 2 to 6 inches long, flowers tricolor, centre yellow, corolla white, tip purple. The structure of the central apparatus is very peculiar, the little lucid tips almost concealrd in the wings.-Var. Hirsutum, several umbels with great many flowers 50 to 60 , pedicels long hirsute.

887. Oligorun tenuifolium Raf. smooth, leaves narrow linear acute uninerve, margin revolute, rugose; umbels sessile multiflore, auricles as long as stamens. - $\mathbf{A}$ very distinct sp. 
from Arkanzas, anonymous in Coll. herb. stem pedal slender, with obtuse angles above as in the last, leaves adpressed 2 to 4 inches long very narrow, umbels 1 or 2 terminal and lateral, flowers bicolor, corol green, centre pale red, the tips very conspicuous black purple.

888. O'TANEMA Raf. meaning auricles without filaments, Acerotis 1818, Asclepias Elliot and authors. Differs from last by central body with membranes for appendages above and no shining hard tips, leaves opposite umbels axillary sessile nodding. I have $3 \mathrm{sp}$. of it, all have simple terete stems and pubescent leaves, umbels multiflore globose, flowers greenish $\&$ c.

889. Otanema latifolia Raf. leaves elliptical or rounded, obtuse or retuse, mucronate petiolate, undulate reticulate roughly pubescent rigid-from the Alleghanies to Kentucky in glades, pedal and sesquipedal, leaves nearly 2 inches long, over one broad, sometimes almost round seldom obovate-Var. Retusa, all the leaves retuse.

890. Otanfma ovata Raf. leaves ovate or subovate, petiolate, acute flat, base often subcordate, roughly pubescent-from New England to Virginia, smaller plant \& leaves chiefly uncial, flowers fewer, perhaps another var. of the last, petiols very short as in last.

891. Otanema lanceolata Raf. Ascl. do Ives \&c? Ascl. nutans and viridiffora Raf. Mg. Pursh \&c leaves lanceolate sessile flat, acute at both ends-from New England to Kentucky \&c. Leaves 2 or 3 inches long, narrow. These 3 plants as in Ansonia and "Upopion show the gradual deviation of species in shapes of leaves.

892. Asclepias megalotis Raf. hardly pubescent, leaves opposite subsessile, elliptic base 
cordate, end obtuse or retuse mucronate, margin ciliolate, nerves reticulate, beneath almost glabrous; umbels lateral subsessile, multiflore, pedicels very short, auricles very large obovate truncate longer than stamens and appendages -Florida, sent me by 'Torrey as the A. obovata of Elliot, which is tomentose with obovate leaves and probably an (Itanema perhaps even a var. of $\boldsymbol{U}$. latifolia. 'This sp. is a real Asclepias, with curved subulate appendages in the auricles, leaves $\mathbf{2}$ or $\mathbf{3}$ inches long, one broad, flowers large white.

893. Asclepias albirlora Raf. Ascl. nivea? and A. incarnata of some Amer. Bot. stem pubescent, leaves ample thin nearly smooth subsessile, elliptical lanceolate, base obliqual, end acuminate, nerves pubescent; umbels terminal corymbose, auricles equal to stamens and appendages-fine sp. from the Unaka or Iron Mts. of $\mathbf{N}$. Carolina, seen alive in gardens, where deerned a white var. of A. incarnata, yet much nearer A. nivea a sp. known to few: with broader shorter leaves, lateral flowers with green petals and white centre says Linneus. This has flowers perfectly white small but handsome, stem bipedal, leares very large 6 inches long, two broad.

I could add or rectify many other sp. of Asclepias, and give again my A. maritima quite different from the smooth A. incarnata; and my A. vanilla the deviation of A. quadrifolia with opposite leaves, but I must leave this for a monograph; I have nearly all the numerous $\mathbf{N}$. Amer. sp. A. cinerea, pulchra, amena, paupercula, amplexicaulis, obtusifolia, curassavica, laurifolia, peroplicifolia, variegata, phytolacoides ofc. I deem this G. must be divided 
into 3 subgenera by habit, which may become G. when the strange floral structure will be ascertained in all.

1. Asclepias, leaves opposite, milky plants.

2. EPTIXIs leaves verticillate, not milky.

3. Stethorhiza, not milky, leaves scattered, type A. tuberosa with all its varieties, decumbens, splendens, imbricata, obtusifolia, angustifolia, undulata, oppositifolia! \&c. Here the sexual apparatus is borne on a pentagonal pillar as in Stylandra or Podostima, but this structure belongs also to Ascl. curassavica and others.

894. ONIST'IS Raf. calix campanulate 5dentate equal, corolla campanul. subentire border pentagone. Stamens 5, filaments unequal thick short smooth inserted at base of corolla, anthers equal linear 2locular opening lengthways. Ovary round compressed, style long thick subclavate, stigma capitate. Fruit a capsule ? discoidal compressed bilocular disperme. Perennial, diffuse leaves alt. and oppos. flovers axillary solitary. $-\boldsymbol{A}$ singular $\mathbf{N}$. G. found anonymous among the Apocynes of Florida in Coll. Herb. but quite different except by habit, and a N. G. of Convolvulines, different from all those established in my fl. tellur. 1001 to 1050 by the calix and pistil, corolla akin but not plaited, stamens quite as in that family. I have not the ripe fruit. The name was a grecian one for some Apocynum.

895. Onistis longifolia Raf. creeping and quite smooth, stem branched diftuse, leaves sessile alterne and oppos. linear graminiform very long obtuse rugose; flawers on axillary peduncles nodding - root white creeping terete now and then swelled up, stems diffuse or prostrate 
only a few inches high, leaves very long ribbon like, 3 or 4 inches in length, 2 lines broad; $\mathbf{f}$. few of a dull yellowish purple, peduncles as long or longer, calix with 5 large equal teeth, nearly urceolate, corolla almost as in Physalis, subrotate when full expanded. Thus habit of Cynanchum rather than Convolvulus.

896. Hydrolea ovatifolia Raf. pubescent inerme, leaves ovate acuminate, flowers terminal fasciculate subsessile-very distinct sp. found in Arkanzas by Nuttal, anonymous in Coll. herb. stem simple pedal terete, leaves scattered uncial, flowers glomerate calix lanceolate hirsute, corolla blue puberulent, styles long, stigmas capitate depressed.

897. Hynolea paniculata Raf, pubescent spinose, leaves linear lanceolate acute, flowers terminal paniculate, subcorymbose pedunculate -found by Kin in Arkanzas, pedal, a short stiff spine at the axil of each leaf, panicle bearing 3 to 7 flowers at the end of the spinose branches, capsules bivalve globose, nearer to $\boldsymbol{H}$. spinosa of S. Amer. than to II. caroliniana. 898. Linum refractum R. stem erect hardly angular pauciflore, leaves linear acuminate reflexed quite sinooth upper oblong, branches few erect uniflore, calix ovate acute uninerveOrigon or Canada, pedal, leaves nearly uncial elongate narrow, shorter almost oblong on the branches, flowers apparently incarnate in the dry specimen, collected by Walton. There are other var. or sp. of Flax in N. Amer. L. virginicum has var. oppositifolium, foliosum, pauciflorum \&c.

899. NEZERA Raf. differs from Linum, calix with 5 segments unequal in size or shape, stamens equal to calix, anthers oblong, styles 5 
very long, stigmas thick oblong capsule 5 locular.-A nother G. of the family Linidia besides those of my fl. tellur. Habit similar, but the inequality of calix is very striking and generic. The name means not true flax, and several sp. of it are perhaps blended in Iinum.

900. Nezera cainea Raf. stem terete virgate branched, leaves linear acute patent crowded, margin smooth, upper subulate distant, flowers racemose few, peduncles equal to flowers, calix segments ovate acute, 2 larger round retuse, petals flabellate-in Florida, bipedal, leaves semi uncial acute at both ends, sometimes imbricate on sterile branches; racemes terminal simple sub-5flore, flowers large of a real flesh color or nankin, not incarnate. The segments of calix are very singular, two are different larger rounded enerve retuse marginate of white, the petals are truly flabellate shaped like a fan.

901. Nezera albiflora Raf. Linum striatum Walter in Coll. herb. stem virgate simple, subangular, leaves linear acuminate adpressed, marmin rough, upper subulate, flowers subcorymbose few, peduncles equal to calix, segments ovate acuminate uninerve, petals obovate-Hills of Georgia and Carolina, pedal slender, leaves smaller and not so crowded as in the last, flowers with $\mathbf{3}$ corymbose branches bearing 2 or 3 flowers, the lateral on short peduncles, calix with unequal segments but of uniform shape, petals white smaller than in last and narrower obtuse not flabellate. Stem not striate as it ought to be in L. striatum of Walter omitted by all our botanists.-I find in a collection of plants made in Texas by Drummond, (and sent me by 'Torrey without names, altho' 
lie says that Hooker has named them in his compendium) two new Flax apparently of this Genus which I have designed as follows.

1. Nezera (or Linum) cuspidata R. stem erect humble striate, leaves linear lanceolate cuspidate; flowers corymbose few, segments of calix acute nervose, 2 larger ovate, 3 smaller ovate lanceolate, petals obovate retuse-l'exas, semipedal, leaves 6-9lines long, flowers large apparently ochroleucous or yellowish white. Annual.

2. Nezera (or Linum) imbricata R. stem erect rigid humble angular, leaves subulate imbricate adpressed acuminate scabrous nervose, flowers dichotome erect, segments of calix subunequal, ovate acuminate nervose margin scariose-'I'exas, annual 3 to 6 inches high, leaves minute, flowers small incarnate? capsule 5locular, 5valve as in Nezera.

902. 'THEROFON Raf. 1828. Boykinia Nut. 1834 not of Raf. 1828. calix 5 fid equal, semi-adherent, petals 5 elongate, stamens $\mathbf{5}$ inclosed inserted on calix, ovary 2-3fid base adherent, 2-3styles short, stigmas obtuse. Capsule 2-3lncular polysperm, dehiscent inwardly above, pa:titions formed by double introllexions. perennial, caulescent, leaves aliernate, fiowers paniculate-a beantiful and rare $G$. of nat. order Diceracea not Saxifragides, discovered by Kin, named by me in 18:28, the name being one of old for Aconiturn, and I had a G. Buykinia out of Ammania long ago. For another Boylinia see 996.

903. 'Tuerofon napellordes Raf. Boykinia aconitifolia N. rar. 81. Heuchera palmata Collins herb.-stem grooved viscid pubescent, loaves petiolate palmate 5-7fid laciniate multi- 
nerve reticulate, petiols and nerves hirsute, panicle formed by corymbs of short secund racemes-handsome plant 1 or $\mathbf{2}$ feet high, not smooth as said Nuttal, but quite viscid by pedicelate glands ap yearing rough when dry, leaves like Napellus, base truncate becoming acute in upper leaves less divided subsessile: flowers white on pedicels shorter than calix unilateral. It grows in the Unaka Mts. or Iron Mts. of North Carolina, a region full of new plants as yet. 'The habit when out of bloom is so like Aconitum napellus that it may be the doubtful plant of that name said to grow there likewise. Probably early vernal.

901. 'TRIODANIS Raf. Campanulacea new G. or subgenus diff. from Legousic by calix with 3 unequal teeth, capsule with 3 unequal cells.-This is apparently a very material distinction; but in one or perhaps more sp. the corolla is besides lacking! or very minute with 5 short sessile anthers, and some deem it a variation! it is indeed a strange one amounting to a Generic character! and thus being perhaps a peloric Genus, a spontaneous late Generic formation! the name means 3 unequal teeth.

905. Triodanis scabra Raf. erect rough humble, leaves sessile oblong acute subentire, upper linear; capsules axillary solitary terete curved crowned by 3 subulate teeth-annual, 2 to 4 inches high, seldom with one or two branches, lower leaves broader subcrenate. Found by me 1823 in the glades near the mouth of the Tennessee $\mathbf{R}$, and by Nuttal at Cedar prairies in Arkanzas; but out of 7 specimens not one is in bloom, all are in seeds, probably very early vernal.

906. Triodanis rupestris $R$. procumbent 
diffuse smooth, leaves sessile reniform subentire, capsules axillary solitary oblong, crowned by ovatoblong teeth.-Annual also, discovered in 1818 on rocks near Baltimore out of bloom as early as May, and also in the Alleghany Mts. 'This was deemed by Torrey a peculiar state of Legousia amplexicaulis, although that plant is erect rough, with different leaves and flowers. I consider them as great anomalies and curious pelorian Genus, as my Lobomon, Myctanthes \&c.

907. Fedia nemiodes Raf. dichotome, leaves obtuse, sessile ciliolate dentate at the base, lower spatulate, upper elliptic, flowers glomerate sessile-in Arkanzas, anonymous in Coll. herb. semipedal, leaves $\mathbf{i}$ or $\mathbf{2}$ inches long, with 2 or 3 large teeth on both sides at the base, but sometimes lacking, flowers terminal in small glomerules.

908. Fenia irgulata Raf. dichotome above, leaves obtuse smooth entire lower obovate or cuneate, upper ligulate, flowers glomerate, corollas with slender tube-another pretty sp. from Arkanzas and Louisiana, hardly pedal, leaves short uncial not ciliolate; flowers white pretty, appearing pedicellated by the long tubes of corollas.

909. Fedia ciliolata R. only once forked, leaves ciliolate, lower petiolate round or obovate, medial cuneate obtuse, upper oblong or lanceolate acute, base sometimes denticulate, flowers in bifid or twinglomerules, corolla short -in Kentucky and Illinois, 4 to 10 inches high, leaves small, longest uncial. It has several varieties or incipient Sp. 1 Ternifolia, semipedal leaves ternate, stem twice trifid, subtriftore-2. Acuta, all the leaves acute entire, upper linear 
flowers few-3 Dentata. last leaves broad and denticulate at base.

\section{CORYMBIFERES.}

Of this extensive tribe of plants, I have yet a crowd of new and interesting $\mathbf{N}$. G. and sp. some of which have been given in the first part, I must here confine myself to some of the most striking, waiting to see what Decandole and Torrey will do; good monographs of the $G$. Aster, Solidago, Erigeron, Helianthus, Coreopsis, Eupatorium, Liatris, Vernonia \&c, or akin and blended are much wanted, and may be undertaken if not well settled by Decandole.

910. NEAC'TELIS Raf. Flosculose, perianthe in triple series adpressed not ciliate, inner colored, phoranthe convex with subulate chaffs, floscules with tube and limb terete tubular, 5dentate, stamens and styles inclosed. Seeds without crown, linear compressrd. Leaves opposite, stem uniflore nearly naled-A singular Genus with habit of my G. Discomela (1825) and the Helianthea with naked stems, yet not radiate; perhaps blended with them as did Collins, and as Elliot blended my G. Anactis with Aster, being his $A$. discoideus. Radiate and flosculose plants are always of different Genera even Senecio and Jacober. My name means Sun without rays. By the seeds near to Espeletia, Heliopsis, Helepta, Acmella \&c.

911. Neactelis strigosa Raf. Helianthus apetalus Coll. herb. stem virgate grooved nearly smooth and naked uniflore, lower leaves opposite oblong acute entire, thick strigose on both sides by white tubercles ending in a bristle, a few short alterne leaves higher up; perianthe with segments ovate lanceolate acute-in Florida collected by Kinn? stem 15 inches, 3 
pairs of leaves at base, one or two inches long, lowest larger subpetiolate, 2 or $\mathbf{3}$ alterne sessile lanceol. adpressed remote further up; but none within 8 inches of the flower, the strigose tubercles very peculiar white unequal ending in a deciduous stiff white bristle. Flower black purple as the disk of Discomela, one inch wide, segments of perianthe in 3 rows of 6 to 8 in each. the inner colored like the flower nearly acuminate, tube of floscules not longer than the tubular limb.

912. AIMORRA Raf. radiate, perianthe simple 8-10partite, rays 8-10 subentire, phoranthe flat, chaffs obovate carinate, florets or floscules tubular without tube 5 dentate, stamens inclosed, stigmas exerted, seeds obovate 4 gone with 4 minute teeth. Erect, leaves alternate,Very near to my $G$. Helepta see first part article Acmella, main difference habit alternate, and toothed seeds: the name was applied by Dioskorides to a Chrysanthemum or Buphthalmum.

913. Amorra acuminata R. Acmella alternifolia Baldw. in Coll. herb.-smogth erect.stem angular, leaves alt. petiolate ovate acuminate serrate in the middle, trinervate reticulate, branches short uniflore, segments of perianthe oblong obtuse-in Florida, stem pedal, leaves over one inch, flowers few yellow on short foliose peduncles or branches, rays apparently obtuse entire.

914. Zinnia floridana Raf. stem solid fuscate triflore, leaves lanceolate, base dilatate subamplexicale, peduncle central very long clavate, segments of perianthe rounded, rays obovate-an indigenous sp. of this pretty Mexican Genus, found in Florida by Kin, in Georgia by 
Leconte, anonymous in Coll. herb, stem pedal quite smooth, leaves levigate over one inch long, peduncle 5 or 6 inches long, calix adpressed turbinate, rays pale red very bload about 8 , the flowers at the end of the two branches sessile and perhaps abortive.

915. BINDERA Raf. N. G. near Aster, Binder in Coll. herb. diff. Aster, perianthe in a double series, each of 10 to 12 adpressed equal scariose segments, rays about 15 entire acute, pappus simple capillary fulvous as long as florets, seeds ovate pubescent. Leares scattred sessile, flowers white, involucrate-apparently distinct from all the $G$. lately removed from Aster by perianthe, dedicated to the discoverer; if not approved as he is not much known as a botanist, I will substitute Xalkitis a grecian name of Leucanthemum.

916. Bindera (or Xalkitis) ciliata Raf. hirsute, leaves sessile cuneate acute, scabrose by adpressed hairs, margin stiffly ciliate; flowers terminal few subsessile, involucrate by 2 or 3 leaves, segments of perianthe linear acute pubescent whitish, rays white, narrow linear acute -discovered by Binder in Louisiana or Florida, branched, leaves uncial crowded, the lower less ciirate, the upper strongly ciliate, flowers uncial, periantise with equal segments in each row, the inner row longer, pappus smooth silky fulvous.

917. JALAMBICA Raf. Flosculose, perianthe $4 \mathrm{fid}$ base campanulate 4 gone, limb spreading, phoranthe flat naked with 4 flowers, 2 la!ger fertile florets opposite, infundibuliform 4fid segments reflexed, 4 stamens exerted elongated, anthers oblong, style bifid elongate, seeds oblong 4 gone crown entire or 4 gone 4 lobed? 2 abortive florets or rays? Annual creeping, 
leaves opposite, flowers solitary-a singular little genus, of which $I$ have $\mathbf{2}$ specimens and a figure of the minute flowers, made by Jalambic, and yet ain doubtful of some of the characters, which must be verified upon the living plants. Dedicated to the discoverer, a botanist who gave many plants of Cuba and Florida to Collins: if already employed Neurelmis meaning worm like neraes may be substituted.

918. Jalambica (or Neurelmis) pumila Raf. smooth, stems creeping prostrate filiform dichotome, leaves on long petiols opposite rounded deltoid obtuse entire with vermiculate nerves; flowers few terminal peduncled.-A minute plant only one or two inches long, found in Cuba or Florida by Jalambic, deemed by him a N. G. of yngen. frustanea or necessaria, leaves only 2 lines long and broad, sometimes decurrent on the petiol, covered by very singular nerves interrupted and quite vermicular. Flowers very small yellowish, the 4 segments of perianthe ovate acute, almost all destroyed for examination by Collins; but this plant will be easily known when met again by the perianthe and leaves when the floral characters may be rectified.

919. Lomaxeta verrucosa Raf. Hymenopappus corymbosus Baldw. in Col. herb. Polypteris integrifolia Nut. El.-I introduce this rare plant to give the synonym of the real discoverer Dr. Baldwin, and rectify the thrice erroneous name of Nuttal, formed of Pteris! 2 already employed by Lacepede for a fish, and 3 not well applying, mine means the marginate bristles of the pappus. In Florida and Georgia between the Rivers Alatamaha and Satilla B.-in a note he says the leaves resemble the back of 
an alligater, and in fact they are covered above with hard and rough warts whence my name.

9 D. Balduina bicolor Raf. nearly smooth, stem grooved $n$ ked above uniflore, leaves scat. tered sessile narrow cuneate obtuse entire,scales of perianthe adpressed broadly ovate acute, 12 wite rays cuncate uneçualy trifid-another $\mathrm{sp.}$ of the real G. Balduina, habit exactly similar, hat flowers larger with white rays and yellow disk. B. uniflora which $I$ have must now be called B. lutea. This was fourd by Leconte in Florjda or Georgia and deemed a N. G. in Coll. herb. stem pedal, leaves uncial becoming less upwards, rays larger than in $B$. lutea, which has a leafy stem, the peduncle incrassate leaves broader adpressed and not crowded.

021. Stevia ovata liaf. herbaceous pubescent, leaves opposite ovate acute serrate crinerve, corymb fastigiate, perianthe 4 flore with 4 segments linear oblong acute, pappus of 4 short obtuse scales. - Texas and Arkanzas, collected by $W$ alton, stem pedal, leaves small hardly uncial opposite subsessile, flowers yellow, florets tubular 4fid obtuse, stamens inclosed, seeds linear smooth compressed, crown or pappus or 4 very short obiuse scariose scales. Probably a subgenus Etetra by the disposition in 4 \&c. All the N. Amer. sp. akin to Stevia appear to deviate as the 2 next Genera evince, even the Mexican sp. include 2 other $G$. the Mustelia of Sprengel with double pappus, and my Tomista for St. pedata with perianthe camp. pappus truncate.

922. DTHAKE Raf. diff. Stevia, perianthe turbinate sub8ffore, segments about 8 nervose, florets with slender tube, limb as long 5parted, anthers subsessile exerted, style elongate hispid, 
tigmas revolute, seeds elongate as long as perianth obverse pyramidal 4 gone, crowned by 8 teeth or short scariose scales, annuals, leaves alternate, end callose, flowers paniculate in. carnate. This $(\dot{H}$. is perfectly distinct by the perianthe, deep cut fforets, scaly crown, leaves \&c. The name means warty apex, the leaves ending in obtuse callosity.

923. Otriake texurfolium Raf. Stevia callosa Nut. stem terete furfurascent, glandular above, leaves narrow linear thickish with ad. pressed hairs, panicle dichotome multifore lax divaricate-in Arkanzas, pedal, leaves uncial often with fascicles at the axils, flowers on long naked peduncles, the segments of florets narrow long linear acute, segments of perianthe cuno. ate acuminate.

924. Othake longifoliom Raf. stem angu. lar and glandular above, leaves broad linenr elongate biuncial thin nearly smooth, panicle pauciflore corymbose, peduncles erect also from Arkanzas, blended by Nuttal with the last, much smaller with larger leaves, semipodal, lower leaves sometimes opposite.

925. XE'TOLIGUS Raf. diff. Stevia, parianthe terete 5 parted 5 flore, segments equal lanceolate enerve, florets exerted with tubular limb sdentate, anthers inclosed, stigmas hardly ex* crted revolute; seeds linear crowned by a pappus of 2 or 3 long rough bristles coalescent at base into a membrane. Leaves opposite, flow ers corymboss incarnate. - Another very dist tinct G. having the bristles of Mustelia without the scales, Stevia salicifolia with 2 bristles belongs thereto, and will be my Xetoliges salictfollius, My name means fer bristles.

926. Xetoligés bRevifolies Raf. smooth; 
stem terete corymbose, leaves sessile ublong linear acute, the upper alternate, corymbs fas. tigiate foliose multiflore, peduncles and perianthes pubescent, segments lanceolate acute pappus of 3 bristles-from 'Texas or Louisana found by Binder, a tall plant probably perennial, leaves short uncial, flowers pale incarnate and handsome profuse.

\section{LIATRIS and VERNONIA.}

These two Genera once blended in Serratula (as so many other G. are in all akin) in. clude a crowd of fine plants deserving a good monograph. Of Liatris our compilers have 18 sp. but I know many more, several being yet blended as varieties, and as they offer various inflorescence must be divided at least in 4 or 5 subgenera: of Vernonia only 10 are in Eaton, my $V$. albiflora and missurica described atl j. 1833 are omitted, and I have many more $N$. sp. Vern. longifolia, latifolia, brevifolia, crinita, humilis \&c. I shall merely add here the subg. of Liatris and a few N. sp.

92\%. LIATRIS Aiton.-1 Subg. Scariola Raf. perianthe squarrose ovate or hemispherical, multiflore, pappus hardly plumose, flowers chiefly racemose or spicate, root bulbose-2d. Teretiola perianthe oblong or terete imbricate adpressed, multiflore, flowers terminal few, root bulbose-3d. Osmilis R. per. hemisph. adpressed multifl. pappus scabrous not featnered,flowers corymbose or terminal, root not bulbose4th Rhodilis $\mathbf{R}$. per. terete 5flore ferv scales colored, ligulate pappus realy feathery, fl. racemose, root bulbose-5th Futhyrsis R. per. 0 blong 5 flore, few scales adpressed, flowers thyrsoidal, root not bulbose-Bth Corymbilis R. 
per. campanulate adpressed paucifore, fi. corymbose, root not bulbose of c.

928. Liatris (Osmilis) amplexicaulis $R$. stem grooved, leaves 5nerved obtuse, radical sessile ovate elliptic, on stem ovate amplexicaule; flowers corymbose, seginents of perianthe cuneate obtuse - a fine odorous sp. blended with L. odoratissina, same exquisite smell like Tonga beans, but weaker bipedal, with broader shorter leaves 2 or 3 inches long.many smaller Howns. The true L.olloratissimum has radical leaves lanceolate acute uninerve 6 to 10 inches long. on stem sessile short cuneate or oblong, few branches uniflore, perianthe foliose segments obovate. In Florida \& Georgia.

929. Liatris (Scariola) botrys R. stem angular rough, leaves smooth scattered linear lanceolate acute, lower longer petiolate, upper subulate; flowers racemose, peduncles longer than flowers somewhat scaly, bracts subulate, perianthe hemispherical, segments obovate obtuse margin red-a very pretty sp. of Florida and Genrgia, more distinctly racemose than in any other, pedal lower leaves 4 to 6 inches, upper uncial, raceme as long as stem multiflore, flowers lax rather small but elegant, styles very long.

930. Litatris (icariola?) vnillora Raf. smooth, stem angular grooved unifiore, leares rigid linear lanccolate acute sessile, the lower elongate, trinerve widdle nerve very thick; perianthe ovate base folio:s scgments ovate acuminate squarrose-from Kentucky to Alabama pedal, leaves nearly imbricate the lower $\mathbf{5}$ or $\mathbf{6}$ inches long. Deviating from Scarield by single flower, perhaps a subg. Rigidilis; but very akin to my L. vigida differing only by 2 or 3 flowers, leaves scab.vi.s stem pilose. 
931. Vernonia reevifolia Raf. stem grooved pubescent below smooth. above, leaves short oblong, margin subentire revolute, very scabrous above, pubescent and glaucous beneath; flowers subumbellate few, segments of perianthe lanceolate acuminate squarrose-in Alabama near to $\boldsymbol{V}$. balduini, which has however leaves ovate serrate, here they are oblong, broader below, or subcuneate, narrow above nearly lancedate, only uncial ; flower in a irregular umbel of about 10 flowers, naked, stem bipedal or less.

932. Vernonia crinita Raf. smooth, stem grooved, leares narrow lanccolate elongate with remote obtuse teeth ; corymb foliose, perianihe crinite by long lax subulate filiform segmentsin Louisiana and Arkanzas near streams a tall sp. leaves 5 to inches long, only half inch broad in the middle, acuminate at both ends and sometimes falcate: flowers large perianthe hemispherical multifl. segments nearly all equal slender and forming a fringed cup as long as florets.

933. Marshallia spiralis Raf. smooth subscapose, leaves radical linear lanceolate obtuse uninerve, scape elongate spiraly srooved, pubescent above, perianthe se smooth-in Arkanzas and West Louisiana found by Binder, near to M. lanceolretre, hut quite distinct, leaves narrower 3 inches long, scape twisted as some Xurides (not so in M. lanceolata) pedal, flower large incarnate.

931. Marshalifa tenuiforia Raf. stem simple virgate grooved, naked and pubescent above, leaves scattered all narrow linear elongate acute perianthe segments linear acute pubescentfound by Baldwin on the sea shores of Florida 
and Georgia, nearer to $M$. cyananthera than M. angustifolia, but leaves quite slender uninerve smooth, anthers also bluish-thus we have 6 sp. of this pretty G. a 7 th might be my $\boldsymbol{M}$. pu inila now my G. T'ierolepta Neog. 1825.

\section{EUPA'TORIUM and akin}

This extensive $G$. is now divided into many Celestina, Brickellia, Mikunia, Kuhnia \&c, besides my Eutrochium with scamose terete perianthe, leaves verticillate \&c, my Caradesia with perianthe hemispherical multiflore: thus reduced to the $\mathrm{sp}$. with a definite number of florets and segments of perianthe, it is still prolific. The American Cacalias are very near, but form 3 peculiar Genera, my Epatitis 205, Mesadenia and Hasteola.

935. MESADENIA Raf. perianthe 5fore, terete with 5 equal segments, phoranthe with a thick gland in the centre and 5 flowers around it, (this gland is an abortive neutral floret sometimes evolved) calicule obsolete or only a small scale, florets with tubular limb deeply 5d, anthers inclosed, stigmas 2 or 4 hardly exerted, seeds smooth oblong or clavate, pappus downy capillary. Perennials, leaves alternate large thickish, flowers white corymbose or paniculate. - A north American G. of many sp, quite distinct and natural by the singular structure of phoranthe, noticed by Elliot and Nuttul, the central gland is variable ovate acute, or angular tridentate, or seldom changed into a neutral floret which has then the ovary dentate instead of downy. I have even noticed some flowers where there was only this neutral floret in the perianthe, lacking anthers and style, another anomaly is the quadruple stigmas of some floretsy This $\mathbf{G}$. is nearer Kleinia than Cacalia. Akin 
also to my Chondrophora (the Chrysocoma nudata of $\mathbf{N}$.) with a scaly phoranthe \&c.I have prepared a monograph of $15 \mathrm{sp}$. whereof 9 are my own, $M$. dentuta, rotundifolia, oblongata, quinquefida, cunpata, pulverulenta, bobata, besides my Cacalia pteranthes and paniculata of annals Nut. 1820, the old sp. are $\boldsymbol{M}$. atriplicifolia, reniformis, ovata, lanceoiat plantaginea (the C. tuberosa of N.) -as to the Cacalia suaveolens $\mathbf{L}$. which Elliot refers to Senecio, it is my G. Hasteola distinguished by the anthers cristate. I will only add here a few of my N.sp.

936. Mesadenia rotundifolia $R$. leaves rounded 3-5nerved entire or repand glaucous beneath, lover on long petiols, obtuse or retuse, uppor sessile acute, flowers corymbose, segments of perianthe oblong obtuse enerve, margin white-In the Musketong and Mahantango Mts. of Alleghanies, 2 or $\mathbf{3}$ feet high, lower leaves 3 or 4 inches long and broad with 5 nerves reticulate, petiols 4 to 8 inches long, upper leaves uncial.

9:37. Mesadenia nentata R. leaves broadly ovate acute and acutely dentate 3-5nerved not glaucous, Jower on short petiols, on stem sessile acuminate, flowers in compound corymb, segments of perianth oblong acute subtrinerve-in Alabama, very different from $M$. ovala with obtuse narrower leaves. Tripedal, leaves 4 to 5 inches long, 3 or 4 broad, petiols 2 or 3 long, stem leaves 1 or 2 inches long, cor ymb with many branches and multiflore.

938. Mesadenia pulverulenta $R$. leaves petiolate 5̄nerved glatrcous pulverulent on both sides, lower on long petiols broadly cordate acute angular, upper ovate or rhomboidal aoute at 
both ends, angular sinuate ; corymbs fastigiate, segments of perianthe lanceolate uninerve margined-in the state of Delaware, 3-4feet high, lower leaves 4 to 6 inches long and broad, petiols as long, on the stem uncial \&c with a short petiol, variously cut in long sharp angles. The M. atriplicifolia has leaves deeper cut, the upper deltoid, the $\boldsymbol{M}$. oblongata has radical leaves oblong cordate obtuse.

939. Eupatorium cinerium Raf. pubescent cinereous, stem striate corymbose above, leaves alternate sessile, on stem lanceolate obtuse, bidentate lateraly, on branches linear entire obtuse; corymbules many pauciflore, perianthe 5 flore, cinereous, segments elliptic obtuse calicule ovate o ituse-in Alabana \&c,tripedal,stem at base redish with cinereous pubescence, lower leaves greenish, upper ashy like the flowers, seeds black hispid, pappus cinereous.

940. Eupatorium fulvim Raf. roughly pubescent, stem simple terete grooved, leaves opposite sesssile oblong lanceolate serrate, acute at both ends, roughly punctate; corymb fastigiate, pedicels hairy white, bracts linear, perianthe oblong pauciflore, segments lanceolate acute glandular punctate, end fulvous membranaceous-in Alabama \&c, near to E. glandulosum of Mexico but leaves not ovate, habit of Kuhnia but pappus not plumose, stem 1-2 pedal, leaves 2-3uncial, flowers fulvous before expansion.

941. Eupatorium or Caradesia pauciflora Raf. Hispidule humble, leaves thin on long petiols ovate crenate, both ends acute; flowers terminal few 5-6, perianthe campanulate multiflore, segments lanceolate acute unequalLourisiana and Mississipi found by Dr. Hart, 
semipedal, leaves small entire at base, corym bule foliose, flowers white incarnate.

I have many other doubtful or rare sp. of this G. 3 were described 1832 in atl. journal $\boldsymbol{E}$. serratum, pectinatum, rupestre, some are in Florula Ludoviciana; as to Entrochium I have prepared a monograph of it with many new species.

HELENIUM of this G. I have 7 sp. and 10 varieties while our botanists admit only 3 .

942. Helenium discovatum $R$. smooth stem dichotome angular, leaves subdecurrent linear lanceolate acute entire uninerve, flowers on long naked peduncles, rays short flat, disk ovate concolor - this was labelled a Rudbeckia in Coll, herb. but is a real Helenium with tritid obtuse rays, bipedal, branches virgate, leaves uncial, flowers smaller than in others. In Florida.

943. Helenium ancers R. Stem compressed striate pubescent with 2 broad wings, leaves decurrent oblong łanceolate acute entire smooth trinerve, flowers corymbose few, rays flat reflexed, disk globular concolor. In Florida and Georgia found by Leconte, anonymous in Coll. herb. pedal, leaves uncial, flowers large.

944. Helenium flexuosum R. smooth, stem ramose angular winged, branches flexuose, leaves decurrent lanceolate acute entire uninerve,flowers paniculate, rays flat reflexed, disk globular discolor-can this be $\boldsymbol{H}$. canaliculatum, but the leaves are not serrate, nor rays grooved. Found on R. Wabash, bipedal, leaves 1 or 2 inches, flowers middle size, discolor redish, not yellow as in other 5 in centre.

945. Her.enium nichotomum $R$. pubescent rough, stem dichotome corymbose striate, wing- 
ed, lower leaves sessile cunente remotely obtuse serrate, not trinervate, upper leaves decurrent lanceolate acute subcrenate, rays grooved? disk globose discolor-another sp. akin to H. canal. iculatum, but not smooth nor properly serrate, stem bipedal quite dichotomous above, lower leaves $\mathbf{3}$ inches long, upper uncial, disk redish as in last, found in W est Kentucky.

946. Heleniur traxilum IR. nearly smooth, stem angular striate hardly winged, leaves subdecurrent lanceolate elongate, both ends acuminate, margin entire very rough ; flower's carymbose, rays flat reflexed, disk globose concotor-found in Indiana and Illinois, pedal, leaves large $\mathbf{2}$ or $\mathbf{3}$ inches long pale beneath, flowers few small.-H. autumnale nearest to this has serrate smooth leaves, and several varieties, an gustifolium, latifolium, levïgatum,brevifoliúm longifolium, elatum, pauriflorum \&c.

\section{GLOSSANTHES}

This family also called Cichoracea and Semtflosculose, has been stated to be very deficient in North America; but it is a mistake, 5 Genera alone Lactuca, Eunoxis, Hieracium, Narbalia and Krigia, include nearly 100 species; being as numerous as the Asters, they have been equaly involved in obscurity by blending or overlooking sp. which require careful moncgraphs, such as I have undertaken; but must delay at present and only give a few striking novelties, as I wish to confine this flora to $\mathbf{1 0 0 0}$ articles at present. This continent is the certral seat of Lactuca as it is of Vitis and Quercus, possessing 30 or 40 species of each. The Lactuca elongata of our blind botanists con. tained $12 \mathrm{nr} 15 \mathrm{sp}$. with leaves smooth or rough, entire or pinnatifid, runcinate, sagittate, den- 
tate, sessile, amplexicaule,flowers spicate or racernose or paniculate! \&c, \&c.

947. Lactuca angulata $R$. smooth gigantic stem fistulose, leaves pinnatifid broad, sinusses wide and angular, pinnules ovate angulate dentate acute, base of nerves roughish, lower subpetiolate angular; flowers paniculate, pedicels inequal, bracts subulate-Pennsylv. to Kentucky \&c stem 5 to 8 feet high, very thick, leaves ample thin pedal below, flowers very numerous.

948. Lactuca maritima R. smooth, stem simple tistular, naked above, all leaves pinnatifid sessile, pinnules remote unequal lanceolate angular; flowers racemose lax few-on the Sea Shores and Sea Islands fromı Long Island to Virginia, stem bipedal purplish, leaves 3 or 4 inches long slender, radical and on base of stem only, how different from last.

949. Lactuca axillaris $R$. smooth, stem fistulose foliose, lower leaves ample sessile ovate lyrate lobaie, sinusses rounded entire, lobes rounded dentate, upper leaves lanceolate entire Howers in axillary spikes-Mts. Alleghanies, stem bipedal fuscate. leaves 2 or 4 inches long, Howers realy spicate sessile.

950. Lactuca ovatifolia R. nearly smooth, stem solid striate, leaves sessile ovatoblong equaly denticulate, middle nerve rough, lower attenuate at base, flowers paniculate, peduncles scaly-in New Jersey and Pennsyl. stem fuscate 2 or 3 feet high, leaves 2 or 3 inches long, veins reticulate.

951. Lactuca pilosa R. stem fistular, base pilose, naked above, leaves all sessile lanceolate denticulate, beneath glaucous and subpilose, lower elongate attenuate into a petiol, flowers 
subracemose few and small-Apalachian Mts. of Virginia and Carolina, different from $\boldsymbol{L}$. hirsula by leaves entire, the lower 6 to 8 inches long, stem 2 or 3 feet high.

952. Eunoxis (Agathyrsus) amabicis Raf. smooth, stem subsolid terete, leaves sessile ample ovate acute angular or denticulate, lower base decurrent cuneiform, floral oblong suben. tire, branches racemose paniculate pyramidal, peduncles elongate naked, flowers blue, pappus white-Mts. Alleghany, 4 to 5 feet high, leaves 4 to 10 inches long, a profusion of pretty blue flowers. I have changed Aguthyrsus name already preoccupied for a $\mathrm{G}$. of shells for $\boldsymbol{E} \boldsymbol{u}$ noxis an ancient name of l.ettuce, and I give this sp. as a specimen out of a dozen sp. that I possess, the color of flowers and pappus is specific in this Genus.

953. Narbalia latifolia Raf. smooth, stem terete flexuose, leaves broad thin petiolate glaucous beneath subdentate, lower on long petiols deltoid hastate broader than long, trinerve, lobes divaricate deltoid acute, upper leaves ovate acuminate, racemes axillary, perianthe 5 flore 5parted-in Mts. Alleghanies, stem 2-3pedal, whitish sometimes rubicund, radical leaves with petiols one foot long, leaf 10 inches broad 8 long, upper leaves 2 or 3 inches long, flowers white drooping, perianthe incarnate. The previous good name Narbalia of Cassini adopted by Hooker must prevail over Harpalyce of Don adopted by Beck later and formed from Harpa a shell. Even the (*. must be divided, I give this as an instance of the real Narbalia, of which I have 25 species, those with multiflore perianthe form my next Grenus; while the Pres nanikes tenuifolia and pauciflora of Torrey 
with plumose seeds are my G. Ptiloria of 1833 Atlantic Journal.

954. OPICIRINA Raf. diff. from Narbalia, perianthe 10-15 segınents commonly hirsute, multiflore, with 20 to $\mathbf{3 0}$ flowers indefinitethese are taller plants, exuding a milk intensely bitter, producing a bitter opium which the name implies; the types are $O p$. crepidinea and the next.

955. Opicrina latifolia Raf. Prenanthes opicrina 1822. smooth, stern grooved ramose, lower leaves with winged petiols cordate or sagittate ovate, sinuate angular, upper ovate repand or denticulate; flowers in racemose panicles fasciculate, perianthes nodding hirsute, pappus fulvous-in Central Kentucky rich woods, 5 to 6 feet high, leaves 4 to 10 inches long, flowers large ochroleucous, perianthes fuscate. Op. crepidinea differs by leaves sessile oblong lanceolate unequaly dentate, $U_{p}$. angustifolia would be a better name.

958. SITIIIAS Raf. perianthe terete double multiflore both multipartite, external shorter adpressed, phoranthe naked, seeds smooth linear oblong grooved, pappus long stipitate simple capillary silky fulvous.-Caulescent, flowers few.-This G. differs from Leontodon by pappus not plumose, from Borkhausia by terete adpressed perianthe and costate seeds. It was shuffled into 4 Genera! Leontodon, Borlihau. sia, Scorzonera, Chondrilla! and now must form a 5th, the name was an ancient of Hieracium of which it has the habit-Type S. CAroliniana Raf. Borkausia do Elliot, see his synonymy and description, wherein he has probatbly blended the next Genus also. My specimen 
from Alabama, has oblong leaves with long teeth and only 2 flowers yellow.

957. CRENAMON Raf. diff. froun Sitilias by outer perianthe unequal, pappus plumose, seeds curved compressed tesselated by longitudinal and transverse stria, scapose, corymbose -nearer to Picris than any other G. the name was that of Adanson for Picris, but different by perianthe realy double as in last and seeds not rugose transversaly alone but tesselate, besides habit scapose.

958. Crenamon pectinatum Paf. smooth, leaves pectinate pinnatifid obtuse, very long and narrow, base attenuate entıre, pinnules remote narrow obtuse, scape grooved corymbose 8-6flore, peduncles very long with subulate scales.-Apalachian Mts. Unaka, leaves 6 to 8 inches long, hardly half inch wide, pectinate like the horn of the Saw-Fish, scape pedal,flowers yellow, perianthe acute, outer rather unequal.

959. Krigia petiolaris $R$. stem flexuose foliose striate pauciflore, leaves all petiolate oblong or obovate minute dentate laciniate, peduncles flliform, perianthes lincar-in Alabama, 3 to 6 inches high, leaves only half inch or less, petiol uncial or longer, flowers small few, not rigidly erect as in $\boldsymbol{K}$ r. virginica.

960. Krigia integrifoi ia $R$. stem erect foliose grooved uniflore, leaves glaucous entire all dissimilar, radical petiolate elliptical obtuse or obovate acute, on stem amplexicaule acute, ovate or lanceolate, perianthe lanceolate-Mts. Alleghanies, how different from last, nearer to $\pi r$. cmplexicaulis but smaller with entire leaves, one small flower pale yellow, not orange color. Semipedal, leaves 1 to 3 inches long, all 
different in shape, yet all entire, - of this difficult $\mathbf{G}$. once blended in Hyoseris, we have 12 or $15 \mathrm{sp}$. and many varieties, difficult to distinguish : the G. Achyrastrum Necker and Cynthia Don, appear the same; if different they must be better distinguished-as to Aposeris Necker with naked seeds, it differs but little from my Laxanon 203, of which it appears Apogon of Elliot is a $2 \mathrm{~d} \mathrm{sp}$. his name was preoccupied for a fish. Our Hieraciums must perhaps be divided, I had formed the G. Ophioseris with many, but the $4 \mathrm{G}$. of Necker out of Hieracium must be verified and restored, they are Aracium, Plancia, Willemetia, and Miegia now occupied by a grass.

961. POLYGALA, this G. now forming a vast family must be divided by flowers and habit, as was suggested by many botanists. I did so long ago, proposing 'Triclisperma, Psychanthus, and Muraltia with many subgenera, that must soon become as in any Genera, I shall merely enumerate them here, reserving $m y$ labor on this family for a monograph.

1. Polygala stamens 8 diadelphous, corolla cristate.

2. Muraltia Neclier 1790 , differs by corolla not cristate, once Heisteria of $\mathbf{L}$. not of Jaquin, since adopted by I. type P. senega \&c.

3. 'Triclisperma Raf. 1814, type P. paucifolia \&c.

4. Psychantius Raf. 1814, type P. myrtifolia \&c.

5. Sexilia R. stamens 6 sessile, corolla bilabiate cristate, type $P$. verticillata and all whorled species, chiefly annudis.

6. Plostaxis R. stamens 4, cor. fimbriate, f. capitate, type P. lutea \&c. 
8. Axthalogea R. stam. 7-8, cor. 3lobe fimbriate, stigma subsessile bilabiate, plumose on upper lip, some flowers deficient, type $\boldsymbol{P}$. polygama.

9. Corymbura R. flowers corymbose.-Subg. or Genus?

10. Zoroxus R. Chamebuxus T. flowers solitary. Ditto?

962. ASEMEIA Raf. diff. Polygala, calix 4-5phyle, 2 sepals internal larger wing like, corolla cariniform base hirsute, subtrilobe, tip tuberculate. Stamens 8 monadelphous very short anthers unilocular. Style elongate bearded above, stigma obtuse, capsule oblong semi-alate, cells monosperm, seeds hispid. Habit of Polygala, perennials, racemose leaves fl. alterne.-I give one of my $\mathbf{N}$. G. very distinct from $\boldsymbol{P}$. senega and akin, altho' same habit, the name means without vexillum.

963, Asemeia rosea R. Polyg. pubescens Mg. E. viridescens Walt. pubescent, stem hardly angular, branched, leaves linear lanceolate acute, calix 4 phyle, wings obovate-in Carolina and Florida, pedal, pretty sp. flowers rose color, leaves uncial, racemes terminal lax, bracts subulate, short.

961. Asemeia carnea Raf. smooth, stem simple angular leaves linear cuneate acute, calix 5phyle, wings ovatoblong - in Alabama and West Tennessee, probably blended with the last, pedal, leaves shorter, the lower cuneate and even obtuse, flowers pale flesh color or white with a pink tinge.

965. Asemeia alba (or leptopsis) Raf. smooth, stem simple angular virgate naked above, leaves narrow linear, upper subulate, raceme spiked, flowers imbricate, calix 5 phyle? wings obovate 
-in Arkanzas and Texas, perennial, pedal slender, leaves very narrow half uncial, raceme terete uncial, flowers white small, on short pedicels almost imbricate, bracts lanceolate: this sp. may be a Muraltia, I cannot determine the stamens.

966. Polygala (Sexilia) missurica Raf. stem branched diffuse 4 gone, leaves quaternate and opposite broad lanceolate smooth, base asute, end mucronate; spikes terminal oblong imbricate-in the prairies of Missouri and Illinois, 3 to 4 inches high, leaves larger and broader than in others, flowers white, not in filiform spikes. Annual.

967. Polvgala (Muraltia?) Rugosa Raf. stems angular prostrate, leaves alternate rugose lower cuneate obtuse, upper linear cuneate acute, flowers in slender spikes-on Lake Michigan, humble, 3 to 6 inches long, leaves less than one inch, flowers red, sessile in short spikes; but very imperfect in my specimen, probably a $\mathrm{Mu}$ raltia.

968. Polygala or Pirostaxis myemalis Raf. stemless, leaves all radical obovate obtuse capitule sessile squarrose oval,bracts lanceolate membranaceous as long as flowers-this and the next are blended in $l^{\prime}$. lutea var. nanu of Mx. but quite unlike our 'P. lutea of New Jersey. Found by Baldwin and Nuttal in Florida and Georgia, blossoning in January, leaves unequal uncial often spatulate, heads shorter than leaves, flowers greenish, root annual.

969. Poiygala or pilos'axis nana Raf. subscapose, leaves cuncate and oblong, obtuse and acute, stem short with 1 or 2 leares lanceolate, head oval squarrose, bracts subulate elongate, wings lanceolate acuminate-in Florida found 12 
by Ware in 1821. Stem 2 or, 3 inches high, leaves half inch long, head large, flowers greenish. I have a var of $\boldsymbol{P}$. lutea near this same size and habit, but with few leaves narrower, heads depressed, flowers realy bright yellow, wings broader obovate acuminate: it will be my var paucifolia, and they all evince a tendency to deviate from P. lulea.

\section{GENTIANIDES.}

This lovely family of plants was in utter confusion, as $I$ have proved in rectifying it, in $\mathbf{f l}$. tellur. 435 to 500 , where many $\mathbf{N}$. G. and sp. are established. I have also restored the $\mathbf{G}$, Anthopngon, Pneumonanthe, Dasistepha, $\mathbf{C i -}$ minalis, Cicendia, Tretorhiza \&c of former botanists, neglected by the linnean blenders. I there gave also some new N. Amer. sp. and I still mean to give hereafter their complete monograph, our species have been increased lately by myself and Hooker ta 50 or 60 , while Linneus had only half a dozen of this continent. I now must merely add some other interesting novelties.

970. Anthopogon incarnatum Raf. Gentiana purpurea Muhl. fl. lancastr. Coll. herb. stem humble branched, branches compressed sub4gone uniflore, leaves lanceolate, acute, lower subcuneate, calix 4gone, segments ovate lanceol. acum, margin colored, 2 alt. narrower, corolla ciliate twice as long-another beautiful sp. of this fine G. discovered by Mublenberg since 1790, found by myself in the Alleghanies 1804, since omitted or mistaken for a variety by our botanists (myself included) but now restored and fixed, only 6 to 10 inches high, with several erect branches, leaves uncial, narrower than in $\boldsymbol{A}$. crinitum, hroader than in $\boldsymbol{A}$. virgatum fi. tel. 
472, flowers size of the first, but of an incarnate color, instead of blue, the calix is margined of same color. Autumnil.

971. Anthopogon albescens Raf. stem terete trifid,leaves patent narrow lanceolate acute, peduncles terete, calix deeply $4 \mathrm{fid}$, segments ovate lanceolate obtusely acuminate, 2 narrower lanceolate, corolla hardly longer than calix unequally denticulate-in Louisiana, collected by Riddel, sent me anonymous, very distinct by smaller shorier flowers nearly white or blush color, leaves nearly as in A. virgatum but broader and spreading, 2 inches long, flower only uncial.

972. Antiopogon brevifolium Raf. humble, uniffore? foliose anceps, lower leaves cnneate or spatulate acute, upper ovatoblong short acute, calix with segments shorter ovate lanceol. acutely acuminate, corolla double of calix fringed-in Mts. Alleghanies of Lycoming $\mathbf{C y}$. Perunsylv. blossoming in November, stem 4 to 6 inches high. leaves very short 4 to 6 lines long and reaching to near the flower, which is small though elongate uncial, apparently incarnate in the specimen, nearer to $A$. incurnatum than to $\boldsymbol{A}$. crinitum, perhaps a variety of it.-A. crinitum differs from all my $4 \mathrm{sp}$. by leaves ovate lanceolate subdeltoid, flowers large with rounded segments deeply fringed, peduncles naked 4gone \&c. All belong to the G. $A$ thopogon of Necker 1790, and have the calix unequal as in the whole family.

973. Pleienta quinquenervia Raf. stem terete trichotome, leaves broad oblong lanceolate acute thin 5nerved; flowers corymbose, calix base membianose, 6-7parted, segments folinen lennonlate. swhenunl in corolla segments 
oblong obtuse-in Louisiana, sent me by Riddel as Sabatia gracilis? pedal, not slender, foliose, leaves large often $\mathbf{2}$ inches long, flowers few white terminal, peduncles thick erect uncial. My G. Pleienta f. tel. 497 includes an the Sabatias with unequal mnltiple calix and corolla, 6-12 stamens, style erect.

974. Pleienta leucan'ria. R. slender 2-3ehrotome branches anceps, leaves lanceolate acute hardly trinerve, flowers on long peduncles,calix 8-10parted linear, corolla double of calix, segments cunecte obtuse-this is the Sab. gracilts of many botanists, but not of all, the trite otfe not being a Pleienta! on Sea Shores from South New Jersey to Florida, pedal, leaves uncial, flowers large and fine, sometimes 2 inehes wide

975. Sabbatia? nervosa Raf. ramose patr ciflore, branches anceps, leaves ovate lanceolate trinerve acute, peduncles axil. and terminal, calix base campanulate 5gone, segments linear elongate nervose, corolla as long as calix, segments broad obovate, trinerve at baseanonymous sp. of Nuttal, which deserves perhaps to be a genus Neurola Raf. by calix 5 gone corolla nerved, stamens rolled up but not twist ed, style declinate and with lineor stigmas as in Sabbatia. From Arkanzas, 8 inches high, leaves small remote semi-uncial, flowers Iarge over uncial incarnate? Neurola askatticu will be a better name.

976. BILAMISTA Raf. calix deeply 5parted subequal, corolla marcescent tube campanulate 10 nerved, limb rotate 5 parted, glundular appendages at the sinusses,stamens 5 free equal filaments suliculate exerted, anthers obtong 210 cular, ovary compressed, style flexuose persis- 
tent, stigma bilamellate broad, capsule elliptic 2valve unilocular, polysperme, seeds scrobiculate inserted on 4 large placentas. P'erennial, ramose, flowers axil. pedunculate-I now add another beautiful N. (i. to the Gentianides: it is next to Swertia and Narketis, but with the calix and corolla of Sabatia \&c. My Narketis fl. tel. 477 based on various sp. of pentandrous Swertias included even several G. this, another my Synallodia japonica, with 2 stamens united, formed by Swertia rolata of Thunberg; and Gentiana pratēnsis with very unequal calix and no appendages? perhaps another Leimanisa $\mathbf{R}$. the name of this applies to the large bilamellate stigma, it shows beautifully the opposition of stamens essential to the Gentianides.

9:7. Bilanista grandiflora Raf. Gentiana do Coll. herb. ramose 2-3dichotome, branches fastigiate terete rugose, leaves ovatoblong acute trinerve; peduncles axilary and terminal rigid angular, calix segments subulate, corolla thrice as long, segments obovate obtuse-fine robust plant of Red river Louisiana and Arkanzas,sesquipedal, leaves biuncial, flowers white? (ful+ vous in dry specimen and leaves blackened) very large 2 or 3 inches wide, nearly marcescent and persistent like the style; capsule large very peculiar black rugose, seeds numerous minute dotted: the glandular appendages are minute somewhat crested and at sinusses instead of segments.

I have not yet exhausted the N. G. and sp. of this family, there are still others blended in Swertia, Exacum, Chironia ... and many unnoticed sp. of Sabatia, Pleienta, Xolemia ... 
see my medical flora and ft. tellur for some of them.

\section{LABIATES.}

In this family much remains to be donc even after the labors of Bentham and mine in fl. tellur. Our G. Pycnanthes, 'T'eucrium, Brunnella, Lýcopus, Mentha, Salvia, Monarda, Scutellaria \&c are yet susceptible of revision and improvement. My G. Euhemus 1830 Med. f. for Lycopus Virginicus and akin sp, must be admitted like my IBlephilia, Vleckia, Blephiloma and others of fl. tellur. I shall only add now a few presumed new species, others are in $2 d$ part of this work.

978. Mentua cinenfa R. cinereous pubescent, leaves subsessile ovatoblong acute sharply serrate, spikes terminal verticillate naked,bracts subulate equal to flowers. stamens included-in the Welsh Mts. of 1lleghanies in P'ennsylv. discovered 1804 again 1834, habit of $M$. tenuis less odorous, root creeping, many stems erect, pedal almost hirsute, leaves uncial quite cinereous beneath, less above, spikes short, flowers small white, calix and bracts cinereous almost canescent.-I have several other sp. of Mint, M. capitata, M. dentata, pectinata, ciliata, trachiloma \&c, but some are doubtful, and the two last belong to Pulegium like M.canadensis and borealis.

979. Vleckia bracteata $R$. leaves petiolate cordate acute grossly serrate, spike sessile bracts also and ovate acute foliose longer than fowers-in Florida, pedal, stem fuscate, leaves uncial not large, spike sessile, rather short, bracts large remarkable. This perhaps may form a subg. the habit and flowers are of Vleckia, but calix more campanulate striate with very unequal teeth, Psalion Raf. see fl. tel. 786. 
980. Pycnanthes saxatilis R. stem ramose tomentose, angles obtuse, leaves glaucous subpetiolate ovate acuminate remotely serrate, hardly pubescent punctate reticulate on both sides; heads terminal sessile, bracts and calix lanceolate mutic canescent tomentose-in the Alleghany Mts. near the R. Susquehannah among stones and rocks, 1 or 2 feet high, branches patent, leaves ultra uncial, capitules multiflure, stamens not exerted.-A var. cuniloides has stem smaller, leaves subsessile smaller oometimes subentire. Subg. Brachystemon.

981. Pycnanties Parvifolia R. smooth, stem branched acutely 4 gone, leaves small subsessile ovatoblong entire, ending by an obtuse callose point ; heads terminal sessile lax dichotome, bracts lanceolate nervose, the nerve protruding in a long stiff fulvous bristle, calix bristly-a very distinct sp. found by Leconte in Florida and Georgia, anonymous in Coll. herb. pedal, while leaves 4 to 6 lines long, bristles of bracts as long as them formed by the nerve extending out. Very different from P.aristata, stamens not exerted. Perhaps a peculiar subgenus Xetalix $\mathbf{R}$. with all aristate sp. here the calix is equal else it would be a I'ullya, lower lip of corolla equaly trilobe, lobes short rounded upper entire? as in Tullya.

982. Pycnanthes ciliata R. stem branched pilose 4 gone, leaves subsessile glaucous lanceolate elongate acute at both ends subentire, smooth, margin and nerves ciliate, heads terminal sessile canescent pilose lax, bracts and calix subulate aristate bristles ciliate-in $\mathbf{N}$. Jersey pine barrens and Maryland, iioticed since 1802, deemed P. aristata by some, nearer to P.pilosa, having both they are very different from 
this, bipedal, leaves biuncial, inflorescence as in last, but bristles not rigid plumosely ciliate, corolla with upper lip emarginate, lower with 3 elliptic lobes unequal. Probably another subg. also Blephixeta Raf.-I have several other doubtful N. sp. of this G. Pycn. scabra, glandulosa, laxiflora \&c.

983. Blephilia Brevipes $R$. stem fistulose hardly angular hirsute chiefly near the nodes, leaves on short petiols upper sessile, ovatoblong nearly obtuse subserrate, smooth, nerves pubescent ; whorls densiflore, bracts and calix hirsute lanceolate aristate-Alabama, leaves uncial, the floral are quite sessile, flowers white incarnate. One of the sp. blended in Monarda hirsuta, the real sp. is my $\boldsymbol{B l}$. nepetoides, a $3 \mathrm{~d}$ is the next.

984. Blephilia lanceolata R. stem deeply 4grooved quite hirsute, leaves well petiolate lanceolate, base acute, end acuminate, margin remotely serrulate; flowers shorter than petiols, bracts and calix lanceolate ciliate with long filiform bristles-in Kentucky, Indiana, Illinois, discov. 1818, well distinguished from $B l$. nepetoides with broad leaves and white flowers, by the narrow leaves and flowers pale incarnate, a large plant 3 to 4 feet high, inuch branched, lower leaves often ovate lanceolate, whorls 3 to 5 , the last without leaves. - There are also $3 \mathrm{sp}$. blended in Monarda ciliata, my Bl.pratensis, brevifolia and heterophyla.

985. Teucrium levigatum Raf. quite smooth, stem with 4 thick obtuse corners and 4 grooves, leaves subsessile broadly lanceolate acuminate subequaly serrate; raceme sessile lax oblong, bracts lanceolote equal to calix smooth angular. -One of the sp. blended in T. virginicum, that 
few botanists can distinguish from canadense, and as both names neither apply nor convey any meaning, I propose to abolish them, and give 7 good names instead for the sp. therein blended: they all are realy of this $G$. and have similar racemose habit. This has a yellow ramose stem sesquipedal, leaves 2 or 3 inches long spikes 3 to 6 inches long, flowers incarnate as in nearly all. Chiefly in Western States.

986. Teucrium petrolaris R. puberulent, stem with 4 grooves and obtuse angles, leaves on long petiols ovate acute, equaly serrate, base acute entire; raceme pedunculate terete dense tomentose, bracts acurninate equal to calix, the lower ovate, calix canescent not angular---how different from the last! nearer to $T$. canadense, pedal, leaves biuncial not tomentose nor white beneath, raceme quite separated from the leaves and compact. In New Jersey, Long Id. and Virginia, often on the sea shore and with radical surculi as in Euhrmus, but this happens also in others. My T. riparium or Canadense has ovate leaves rounded at base, tomentose white beneath, shorter petiols \&c.

987. Teuorium bracteosum R. nearly smooth stem grooved, angles obtuse, leaves on short petiols, lanceolate unequaly serrate, acuminate; raceme foliose, flowers axillary to leaves and long bracts laciniate, upper entire, calix smooth not angular-another very distinct sp. pedal, leaves 1 or 2 inches long, with flowers at the axils, pubescent beneath. In N. Jersey, Pennsylvania, Virginia, the $T$. virginicum of some botanists.

988. Teucrium lanceolatum Raf. and Collins, stem simple pubescent grooved, angles acute at both ends, subequaly serrate, nearly smooth, 
nerves pubescent, raceme sessile interrupted whoiled, bracts subulate equal to ca ix canescent tomentose not angular-nearest to $\boldsymbol{T}$. le vigatum and $\boldsymbol{T}$. virginicum or rather my $\boldsymbol{T}$. obliquatum with ovate obliqual leaves petiolate, unequaly serrate, pubescent beneath. This is found from New Jersey to Virginia, is pedal, leaves biuncial narrow, root nodose creeping as in most species. It was noticed by Collins as a N. sp. .

989. Trucrium cinereun R. ramose puberulent, stem grooved angles acute, leaves subpetiolate elliptic or broad oblong acute at both ends subequaly serrate, beneath tomentose but not white; racemes elongate sessile slender, calix scattered cinereous pubescent angular subsessile, bracts subulate equal-o-in East Kentucky and Tennessee the Cumberland Mts. and Cheroki Mts. large sp. bipedal, leaves $\mathbf{3}$ to $\mathbf{5}$ inches long, half as broad, raceme 6 to 10 inches long.-.-Thus our 7 Teucriums differ in stems, leaves, petiols, racemes, bracts and calix, agreeing in nothing but creeping root, erect stems, serrate leaves and incarnate racemose flowers.

\section{EUPHORBIDES.}

Although I had revised and corrected the Genera blended in Euphorbia, in fl. tellur. 1168 1190 , I have yet the pleasure to add now $2 \mathrm{~N}$, G. of North America, that would have been refered thereto.

990. ZALITEA Raf. Dioical, perianthe male campanulate 5fid, segments ovate acute erect, each having upon their base a lunulate gland. Stamens few short, several castrate or sterile filaments. Female... Leaves opposite narrow petiolate, flowers axillary sessile.-A singular G. perfectly new, anonymous in Collins 
herb. with habit quite peculiar, next to Lepadena by glands opposite, but habit totaly unlike and perianthe not 8fid. Zalitea was an ancient name of this family or Polygonum.

991. Zalitea Linearis $\boldsymbol{R}$. stem grooved 2-3chotome, leaves remote oppos. petiolate, linear, base acute, end mucronate, flowers subsessile, solitary in dichotomies and axils---annual smooth plant, erect? but weak, subpedal, leaves distant uncial, not obliqual, flowers small green with $\mathbf{5}$ ovate segments, acute which is unusual in this tribe, inner glands yellowish lunulate, ends obtuse concavity beneath. Seeds not seen but probably as in Lepadena. It grows on Red River of Louisiana,collected by Binder 992. APLARINA Raf. dioical and monoical, perianthes uniflore, male perianthe tubular, minutely 4 lobe at top, lobes unequal ovate subserrate, a single stamen exerted borne upon a terete androphore, rudiments of some sterile. Female perianthe campanulate 8 lobe, lobes subentire 4 alterne shorter. Capsule villose, stigmas 3 bilobe. Habit of Xamesyke.-Another G. remarkable by declinity and different perianthes, the male uniflore or monandrous. The name means simple stamen. There are many sp. of this G. blended in Euphorbia, I have lately noticed that $\boldsymbol{E}$. hypericifolia probably belong to it.

993. Aplarina prostrata Raf. prostrate pu. bescent, stems terete, dichotome, leaves petiolate obliqual ovatoblong acute, subserrate ; flowers in axils solitary subsessile-annual, laying flat on the sand where it grows in Pennsylvania. blended by myself with the akin G. until the flowers well examined, and perhaps other sp. belong also here. Several stems 3 to 6 inches 
long, leares minute 2 or 3 lines long, flowers very small, green but lobes white.

994. Arlarina? MYrophya $R$. prostrate smooth, stems terete ramose, leaves on short petiols rounded subcordate obliqual entire obtuse or retuse; flowers solitary pedicelate-in Lonisiana and 'Texas, same size, but leaves very minute only one line long, fowers few and so minute that I cannot avalyze them, they are apparently campanulate 4 lobe and male, no' capsule being visible.

995. Synexemia cuneifolia Raf. stems erect simple, leaves petiolate adpressed cuneate acute, stipules subulate; flowers extra-axilary solitary or geminate pedunculate-Louisiana and Arkanzas, stems humble 2 to 4 inches high, leaves 3 lines long, flowers minute. For my G. $\boldsymbol{S y}$ nexemia 1825 (Mascalanthus Nut. 1834) Eee my Neogenyton and fl. tellur. 1191.

996. ARKLZOS'TIS Raf. Cucurbitacea near Melothria, diff. $\mathrm{fl}$. hermaphr. and male, minute campanulate 5 fid, ovary oblong constricted above,style with single stigma trilobe almost coadunate with 3 stamens monadelphous and syngenese covering it. Male fi. still smaller, stamens subsessile. Berry oblong trilocular trisperme! Habit of Melothria, but flowers "ud berries subsessile.-A distinct G. probably blended in our Melothria chiefly different by $\mathbf{3}$ seeded berries sessile. It was once sent me by Dr. Short as the Boylinia trispora of Wray and Nuttal, but my Therofon (see 902) is the only Boylinia published by Nuttal. My name ivas a classical one of Bryonia.

997. Arkezostis quivoueloba R. scandent roughish, stem striate, leaves petiolate cordate כ́lobed, sinusses obtuse, lohes ovate acute re- 
pand, middle lobe often trifid; flowers axillary, geminate or ternate subsessile-in Florida and Georgia, where first discovered by Dr. Boykin and called Melothria sessilis, but never published. Stem slender 3 or $\mathbf{4}$ feet high, climbing with tendrils, leaves 2 or 3 inches broad and long, flowers green very minute, berries not seen probably oval and black as in Melothria.

\section{SAMOLIDES.}

I conclude by 3 new plants of this family of mine established 1815 ... which is now greatly increased since all the Houstonias, some Hedyotis and several presumed Rubiacea will belong thereto. Decandole has by mistake deemed the Houstonias of Gentianides tribe, because he found the stamens opposite to corolla; but then Samolus which is lately put with Primulacea, should also rank with Gentians; yet the Samolides differ by adherent or inferior ovary as in Rubiacea, and these differ on'y by alternate stamens, essential character, little attended to till noticed by Jussieu in several families, but overlooked in Houstonia and Gentians. Every Genus with stamens isoperial or equal in number to segments of corolla, must be verified and ascertained if opposite thereto.-The Oldenlandia or Hedyotis uniflora is a Samolides and a peculiar G. my Edrastima uniflora. 'The $\mathrm{O}$. or H. glomerata is another $\mathbf{G}$. with unequal calix, my Stelmotis glomerata.

998. Houstonia biloba Raf. dwarf dichotome leaves linear oblong acute, lower petiolate; flowers axilary, peduncles equal to leaves, corolla tube campanulate, limb patent, capsule compressed obcordate bilobe-in Arkanzas, small plant 1 or 2 inches high, leaves 2 or 3 lines long, flowers red, segments of calix linear; 
of corolla oblong obtuse, capsule almost like Veronica, but semi adherent, 2locular, polysperme, seeds reniform. Probably a subgenus, EтoroTis Raf. meaning eared heart.

999. Houstonia feniculata Raf. stem geniculate 1gone assurgent, leaves subfasciculate lanceolate acute, margin rough; flowers axilary solitary, corolla tube filiform, limb campanulate 4fid-on the Wasioto hills of Kentucky, annual semipedal, leaves uncial pale beneath, flowers purple, calix linear, tube of corolla double of calix. Another subgenus by peculiar corolla, I will call it Goniotis, I have not seen the capsule.

1000. Houstonia reticulata Raf. stem geniculate 4 gone erect, radical leaves petiolate obovate, on stem larger ovate acute trinerve, veins reticulate, margin rough, flowers terminal few corymbose, peduncles 1-3flore, capsule globose-Alabama, annual 3 to 4 inches high, akin to $\boldsymbol{H}$. purpurea, but radical leaves different and smaller, on stem often uncial, calix adherent with two thirds of ovary, segments linear.-A var. triflora has only $\mathbf{3}$ flowers, some leaves oblong mixt, either obtuse or acute.

For other sp. of Houstonias see my monograph of 1820 , it must form several subg. or even Genera. I have all our sp. $\boldsymbol{H}$. serpylifolia, patens, rupestris, tenuifolia, longifolia, angustif. heterophyla, pubescens, purpurea, varians \&oc and I may give another monograph of all the Samolides, of Samolus itself I gave one in my herbarium Rafinesquianum.

I must now conclude this Flora, although I have left many families untouched in which I possess many novelties ; particularly in Gratiolides, Acanthides, Personates, Scrophularia, 
Ludwigia, Oenothera, the Malvaceous, Cruciferes, Hypericines, Leguminose, Verbenides, Caryophyles, \&c, besides all the Monocotyles, Asphodelides, Helonides, Xurides, Grasses and Cyperides, Ferns and Cryptogams .... which must be described in supplemertal Monographs or peculiar additional works.

\section{APPENDIX.}

ADDITIONS AND CORRECTIONS.

In the course of such elaborate works, there are always some corrections to make, for names, synonyms or facts that have escaped attention: while additions might be lengthened ad libitum. Only a few will be stated here, being chiefly essential corrections.

IN FIRST PART-LEXICON.

1. Abalon. Add in syn. Chamelirium Wild. Ophiostachys Redoute: all names posterior to Abalon of Adanson 1763.-In 1837 Grey has made it a subg. Chamelirium! in G. Helonias! calling it Hel. dioica like Pursh, and he reduces Helonias to $\boldsymbol{H}$. bullata! although quite different: he takes no notice of the synonym of Thunberg, Melanthium luteum of Japan,which is a third Genus blended my Siraitos aquaticus fl. tellur. 865.

2. Aвama Adanson 1763 was perhaps previous to Tofielda of Hudson (what date?') compare my monograph, with that of Grey 1837. He has some additional sp. but his subg. Triantha Nuttal is the real Abama 60 years older! that must be a Genus as stated.

3. Acroantues Raf. 1808, not 1818 as misprinted, well named ten years before Nuttal.

4. Acrostichum auneuir, Kunth describes 
under that name another sp. quite unlike it or my $\boldsymbol{A} c r$. maritimum!-I call it Acr. acuminatum Raf. pinnulis lanceolate acuminate base rounded petiolate entire thin costate, smooth above like stipes, beneath quite fructiferous all over. In Venezuela, ten feet high-I have found in Collins Herb. a very curious fern of Florida collected by $\mathbf{K}$ in or Baldwin again as a doubtful Acr. aureum? which forms a most beautiful and wonderful $\mathbf{N}$. G. of dorsiferous ferns without Sori, but with capsules unconnected punctiform scattered like minute dots. It shall be fully described and figured in $\mathrm{my}$ Pterikon,a work now preparing. I announce it meantime as a great discovery proving that the capsules of Ferns may be solitary, and I call it.

5. NESORIS BIcolor Raf. smooth, bipinnate, yellow beneath, pinnules sessile oblong crenate lobate, base acute, end obtuse, above nervose flabelate, behind enerve golden furfurascent, capsules irregularly scattered.-Pedal, stipes brown shining convex behind, grooved before, pinnules alternate, 25 to 33 on each branch, gradualy smaller and nearly confluent. In Florida-I have several other N. G. of Ferns, but none so beautiful and anomalous; probably type of a new family Nesorides.

6. Olsynium; read Sisyrinchium throughout, misprinted Siryrinchium in the synonyms. See 878 flora tellui. where it is again described, another sp. added, and the akin blended Genera compared and settled.

Monograph of KUHNIA.

Although I thought this monograph nearly complete, I have found other new sp. in Collins Herb. and I am told that Decandole in his 5th volume just published has many sp. under $\mathbf{3}$ 
Genera! Kuhnia,Critonia and another? Therefore my labor shall have to be still further remodeled hereafter, meantime I will give here the additional $\mathbf{N}$. sp. making 14 altogether.

7. Kuhnia glomerata Raf. $K$. critonia? Nut. in Collins herb. smooth, stem grooved, branches terminal corymbose short 3.5flore, leaves scattered subsessile lanceolate short remotely serrate, flower's subsessile glomerate, pappus fulvous-Apalachian Mts, pedal, leaves uncial, flowers forming small round heads particularly after anthesis when they spread out.

8. Kuhnia latifolia Raf. K. critonia! Coll. -nearly smooth, stem corymbose striate, leaves alternate sessile ovate oblong, grossly serrate, acute at both ends, very thin, on branches narrow oblong subentire, branches 1-3ffore, flowers pedunculate, pappus fulvous-in Florida, leaves almost as in $\mathbf{K}$. elliptica, but longer biuncial, on branches uncial quite different, never trinervate.

9. Kunnia virgata Raf. smooth, stem and branches virgate, striate whitish, leaves scattered sessile linear entire acute, flowers corymbose, pedunculate, pappus fulvescent-in Carolina and Florida, deemed $\boldsymbol{K}$. eupatoroides by Collins, nearer the Critonias ; still nearer to $\dot{K}$. tuberosa of Elliot. Tall plant, long slender branches, leaves uncial, perhaps $\boldsymbol{K}$. albicaulis would be a better name.

Three other sp. were blended in Coll. herb. as $\boldsymbol{K}$. eupatorioides, not a single one being that sp. since they had all fulvous pappus; one was K. fulva, a 2d my K. pubescens from Cotocton Mts. on Potowmak, the 3d the next.

10. Kuhina divaricata Raf. scabriuscule, stem grooved fuscate, branches paniculate divari. 
cate nearly naked, leaves scattered petiolate lanceolate grossly serrate, flowers corymbose pedunculate pappus fulvous-Apalachian Mts. tall plant, leaves uncial.

11. Kunvia cinerea Raf. cinereous pubescent, stem grooved corymbose above, leaves scattered sessile adpressed linear lanceolate entire; flowers fasciculate pedunculate cinereous, pappus fulvescent-a fine sp. found by myself in the Cumberland or Wasioto Mts. of East Kentucky and T'ennessee, blended with $\boldsymbol{K}$. pubescens, but now well distinguished and separated. Bipedal, leaves biuncial often falcate, branches multiflore, perianthe of flowers quite cinereous, floscules also, but not the pappus.

\section{PART-NEOPHYTON.}

12. LAXanon 203, although very near to Lapsana, Aposeris and Aptilon, it is quite distinct from all; Aposeris of Necker differs by caliculate perianthe; my Aptilon which is the Apogon of Elliot, this name being employed by Lacepede for a $G$. of fish, differs by perianthe in a double series and seeds striate as in Crenamon. These Genera will form a small group of the Glossanthes, with naked seeds Aposerides Raf. I have found in Coll. herb. a second sp. of Laxanon from Arkanzas, deemed a doubtful plant near Krigia by Nuttal, I call it.

IAXANoN heterophylum Raf. stem flexuose ramose, radical leaves narrow remotely pinnatifid, segments lanceolate acute, stem leaves amplexicaule, linear lanceol. acute, involucre bifoliate unequal, umbels 2-5flore-Arkanzas, annual, 6 to 8 inches high, leaves 2 or 3 inclies long, flowers on filiform erect pedicels, perianthe commonly 5 partite, few florets or ligules, seeds ovate. 
13. Thecanisia ponpuren 205 read 'Thec. purpurea. Compare this G. with Aegopogon which is Ulmaria of others.

14. Diplostelma 316, add Chetanlhera Nutt al, not of Ruiz and Pavan,norPersoon \&c, thus this name was even employed and not applying as stated in the note at end of part-Acticarnopus misprinted for Actinocarpus.

15. Baptisia 321, add B. versicolor another beautiful sp. of this $G$. has been added from the $\mathbf{S}$. W. which is either akin to $\boldsymbol{B}$. albiflor $\boldsymbol{a}$, or perhaps a Riparia.

\section{PART-NEW SYLVA.}

16. Colema 591, read Corema.

17. Chionanthus maritima 706. compare with it and Ch. heterophylus, the Ch. pubescens of Kunth and South America; but it has red flowers, while all the North American sp. have white flowers.

\section{PART-NEOBOTANON.}

18. Pivina or Piercea obliquata 750; another proof that this is not the $\boldsymbol{R}$. humilis (including many blended sp.) is found in Kunth, his plant of that name is described by him as smooth. with leaves ovate pubescent beneath shorter than racemes. From Mexico, perhaps another peculiar sp. $R$. mollis Raf.

19. Lyonsia 883, this Lyonia of Elliot is previous and very different from that of Nuttal, which is a section of Andromeda, that I have called Hemichis meaning half valves, as the fruit has $\mathbf{5}$ half valves alternate. Lyonia would be almost like Allionia, and the botanist name was realy Lyons. 
20. Trionanis RUPestris 906, this is very near to the Campanula flagellaris of Kunth, perhaps of this Genus. His Mexican C. perfoliata appears somewhat different from ours by flowers geminate and ternate; yet Torrey would have all these to be varieties! which is the type then and the primordial form?

21. Helerium niscovatum 942, compare it with $\boldsymbol{H}$. mexicamem of Kunth, too shortly notired by him.

F.ND OF THIS FIORA. 


\section{INDEX.}

OF GENERA, SUBGENERA \&c.

Synonyms initalics, families in small capitals.

Abalon, Apx 1

Abama, Apx 2

Acerates 885

Acetosa 861-3

Achyranthes 843

Achy Raxthines 830

Acmella 913

Acroanthes. Ap. 3

Acrostichum, Ap. 4

Agathyrsus 952

Aimorra 912

Ammi 781-2

Amorgine 839-41

Anactis 910

Anantherix 884

Ansonia 880

Anthalogea 961.

Antiphyla 756

Anthopogon 970-2

Anychia 830 to 840

Aplarina 962

SApogon 960

Aposeris Ap. 12

Aptilon Ap. 12

Argyrocoma 833, $\$ 39$ Arkezostis 996

Asclepias 979 to 893

Asemeia 962-5

Athamantha 798

Babiron 7\%9 to 782

Balduina 920

Ballimon 794
Baptisia Ap. 15

Batschia 767

Bilamista 976

Bindera 915

Blephilia 983-4

Blephixeta 982

Blutaparon 844-6

Boragines 761

Borkausia 956

Boykinia 902

Buinalis 830

Cacalia 935

Campanula, Ap. 20

Caradesia 941

Chionanthus, Ap. 17

Chondrophora 935

Cicuta 725

Cleomides 756

Cnidium 800

Convolvulus 769 to 871

Corema Ap. 16

Corispermum 847

CoRYMBIFERES 910

Corymbilis 927

Corymbula 961

Crenamon 957

Cynanchum 882

Cyphorima 766

Darluca 872

Dasyspermum 776

Daucus 786 to 796 
Didiplis 736

Dionea 760

Dionidia 760

Diphyleia 736

Diplostelma, Ap, 14

Discolenta 853

Discoplis 740.

Echites 881

Edrastima 998

Entasikon 797-9

Eryvgines 813

Eryngium 813 to 821

Eriogonum 864-7

Etetra 9:21

Etorotis 998

Euhemus 978

Eunoxis 952

Eupatorium 935 to 941 Euphorbides 990

Futhyrsis 927

Evolvulus 808 to 874

Fedia 997-9

Galenides 828

Gentiana 977

Gen'itanides 970-7

Gingidium 783

Glossanthes 947

Gonistis 999

Gonolobus 879

Harpalyce 953

Hasteola 935

Helenium 942-6, Ap. 21.
Helianthus 911.

Hemiclis, Ap. 19

Heptarinia 851

Herniaria 831

Heuchera 903

Hieracium 960

Houstonia 998 to 1000

Hydrolea 896-7

Hymenopapus 919

Labiates 978

Lactuca 947 to 951

Lapathon 860

Laxanon, Ap. 12

Legouzia 904

L cimanisa 776

Leontodon 956

Leptixis 893

Leptocaulis 778-81

Liatris 927-30

Ligusticum 781

Linum 898

Lithospermum 962-6

Littorella $\mathbf{7 4 8}$

Lomaxeta 919

Lycopsis 768

Lyonsia 883, Ap. 19

Marshallia 933-4

Mascalanthus 995

Melothria 752-5

Mentha 978

Mesadenia 935-8

Mesodiscus 969-71

Mitesia 848-50

Muraltia 961, 5, 7

Mustelia 9:21 
Narbalia 953

Neactelis 910

Neleixa 972

Nesoris Ap. 6

Neurelmis 917

Neurola 975

Nezera 899 to 901

Odacmis 828

Oligoron 885-7

Olsynium, Ap. 6

Ombeliffer ous 769

Onistis 894

Ophioseris 960

Opicrina 954

Orimaria 812

Osmilis 927-8

Otamplis 735

Otanema 889-91

Othake 922-4

Pachiloma 811-12

Panax 877-8

Paronychia 833

Peltachila 795

Peplis 738

Psalion 979

Peucedanum 773

Peutalis 848 to 856

Phaiosperma 808 to

812

Phellandrium 799

Phyllanthus 995

Piercea 749, 750, Ap. 18

Pilostaxis 961, 8, 9

Plagidia 834
Plantago 742-7

Pleienta 973-4

Plesili 874

Plumbago 751

Polygala 761-9

Polygonum 848 to 8.59

Polypteris 919

Prenanthes 953

Psalion 979

Pseindes 735

Pselium 735

Psychanthus 761

Ptilimnium 812

Ptiloria 953

Pulmonaria 761

Pycnanthes 980-2

Quamoclita 876

Rhodilis 927

Riddellia 756

Rivina 749, 750, $\Lambda$ p. 18

Rumex 760-3

Sabbatia 975

SAMolides 998

Sataria 772

Šcadiasis $\mathbf{8 1 2}$

Scariola 927-30

Sesuvium 758

Sexilia 961

Sison 781

Sitilias 956

Siumis (sium) 807

Smyrnium 800

Spergula 759

Squibbia 758 
Staplinus 796 Steiremis $\mathbf{8 4 3}$ Stelmotis 998 Stethorhiza 893 Stevia 921-6

Streblanthes 813-16 Stylisma 868-71 Swertia 977 Synexemia 995 Synallodia 976

Teretiola 927

Teucrium 985-9

Thaspium 800 Thecanisia, Ap. 13 Therofon 902 Tiricta 777-8 Tomista 921 Tordylium 811 Trepocarpus 928

\begin{tabular}{|l} 
Triclisperma 961 \\
Triodanis 904-6, Ap. \\
20 \\
Upopion 800-5 \\
Veronica 822-7 \\
Vernonia 931-2 \\
Visnaga 793 \\
Vleckia 979 \\
Xalxitis 915 \\
Xamotris 748 \\
Xetalix 981 \\
Xetoligus 925 \\
Zalitea 990 \\
Zinnia 914 \\
Zizia 806 \\
Zoroxus 961.
\end{tabular}







